\title{
Challenges for work-based learning in vocational education and training in the Nordic Countries
}

\author{
Jørgensen, Christian Helms
}

Published in:

Work-based Learning and professional development in times of globalisation

DOI:

10.1007/978-94-6300-244-8_12

Publication date:

2015

Document Version

Publisher's PDF, also known as Version of record

Citation for published version (APA):

Jørgensen, C. H. (2015). Challenges for work-based learning in vocational education and training in the Nordic Countries. In S. Bohlinger, U. Haake, C. H. Jørgensen, H. Toiviainen, \& A. Wallo (Eds.), Work-based Learning and professional development in times of globalisation (pp. 159-171). Brill | Sense. Research on the Education and Learning of Adults Vol. 4 https://doi.org/10.1007/978-94-6300-244-8_12

\section{General rights}

Copyright and moral rights for the publications made accessible in the public portal are retained by the authors and/or other copyright owners and it is a condition of accessing publications that users recognise and abide by the legal requirements associated with these rights.

- Users may download and print one copy of any publication from the public portal for the purpose of private study or research.

- You may not further distribute the material or use it for any profit-making activity or commercial gain.

- You may freely distribute the URL identifying the publication in the public portal.

\section{Take down policy}

If you believe that this document breaches copyright please contact rucforsk@kb.dk providing details, and we will remove access to the work immediately and investigate your claim. 


\section{Working and Learning in Times of Uncertainty}

\section{Challenges to Adult, Professional and Vocational Education}

Sandra Bohlinger, Ulrika Haake, Christian Helms Jørgensen, Hanna Toiviainen and Andreas Wallo (Eds.)

Sense Publishers

[ESSELA 
Working and Learning in Times of Uncertainty 


\title{
RESEARCH ON THE EDUCATION AND LEARNING OF ADULTS
}

\author{
VOLUME 4
}

\section{Series Editors}

(On behalf of the European Society for Research on the Education of Adults)

Emilio Lucio-Villegas (University of Seville, Spain)

Barbara Merrill (University of Warwick, United Kingdom)

Marcella Milana (Aarhus University, Denmark)

Henning Salling Olesen (Roskilde University, Denmark)

\section{Scope}

'Research on the Education and Learning of Adults' aims at providing an in-depth insight on the diversity of current research on adult education in diverse teaching/learning contexts in both geographical and cultural terms in Europe. Research on adult education has been characterised by different intellectual traditions, theoretical and methodological approaches and which are still alive today in Europe from the north to the south and from the west to the east. This book series is edited by the European Society for Research on the Education of Adults (ESREA). The content of the series reflects the wide range of research activities undertaken by ESREA's members and networks such as: access, learning careers and identities; active citizenship; the professional development of adult educators; working life; the history of adult education; gender; local development and adult learning; ethnicity; older learners; adult education policies and biographical research. This book series will appeal to an international audience as it engages with current and relevant empirical research, a range of theoretical perspectives and knowledge thus stimulating debate, discussion and knowledge dissemination in the field in a democratic and heterogeneous way.

\section{Editorial Advisory Board}

Michal Bron Jr. (Södertörn University College, Sweden)

Anja Heikkinen (University of Tampere, Finland)

Françoise F. Laot (University Paris-Descartes, France)

Linda Morrice (University of Sussex, United Kingdom)

Joanna Ostrouch-Kamińska (University of Warmia and Mazury, Poland)

Angela Pilch-Ortega (Graz University, Austria)

Andreas Wallo (Linköping University, Sweden)

Georgios Zarifis (Aristotle University of Thessaloniki, Greece) 


\section{Working and Learning in Times of Uncertainty}

Challenges to Adult, Professional and Vocational Education

Edited by

Sandra Bohlinger

Dresden University of Technology, Germany

Ulrika Haake

Umeå University, Sweden

Christian Helms Jørgensen

Roskilde University, Denmark

Hanna Toiviainen

University of Helsinki, Finland

and

Andreas Wallo

Linköping University, Sweden

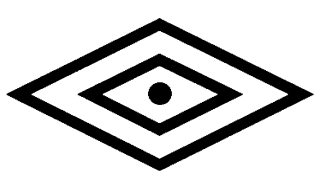


A C.I.P. record for this book is available from the Library of Congress.

ISBN 978-94-6300-242-4 (paperback)

ISBN 978-94-6300-243-1 (hardback)

ISBN 978-94-6300-244-8 (e-book)

Published by: Sense Publishers,

P.O. Box 21858,

3001 AW Rotterdam,

The Netherlands

https://www.sensepublishers.com/

Printed on acid-free paper

All rights reserved @ 2015 Sense Publishers

No part of this work may be reproduced, stored in a retrieval system, or transmitted in any form or by any means, electronic, mechanical, photocopying, microfilming, recording or otherwise, without written permission from the Publisher, with the exception of any material supplied specifically for the purpose of being entered and executed on a computer system, for exclusive use by the purchaser of the work. 


\section{TABLE OF CONTENTS}

The European Society for Research on the Education of Adults (ESREA) vii

1. Introduction: Working and Learning in Times of Uncertainty 1 Sandra Bohlinger, Ulrika Haake, Christian Helms Jørgensen, Hanna Toiviainen and Andreas Wallo

\section{Part 1: Micro Level of Working and Learning}

2. Configurations of Learning in Global Work Hanna Toiviainen

3. Work and Learner Identity: Developing an Analytical Framework Sissel Kondrup

4. Key Predictors of Learning Transfer in Continuing Vocational Training: Development of a Theoretical Framework and Testing of an Empirical Model with Structure Equation Modelling (SEM)

Michael Gessler and Anja-Christina Hinrichs

5. Knowledge Development in Internship: A Case-study of Students' Access to Tacit and Explicit Knowledge in Blended Learning (BL) Programmes

Susanne Dau

6. Leadership in Times of Globalisation and Uncertainty

Gun Sparrhoff

\section{Part 2: Meso Level of Working and Learning}

7. Police Students' Values of Competence Related to a Professional Career

Thomas Bäck

8. Police Leadership Practice in Times of Uncertainty and Organisational Turmoil

Ola Lindberg, Oscar Rantatalo and Ulrika Haake

9. Dilemmas in Automation Engineers' Daily Work and the Changing Form of Learning Kirsi Kallio 
10. Employee Resourcing in Elderly Care: Attracting, Recruiting and Retaining the Right Competence

Dan Rönnqvist, Andreas Wallo, Peter Nilsson and Bo Davidson

11. Recognition of Prior Learning within Elderly Care Work Andreas Fejes and Per Andersson

\section{Part 3: Macro Level of Working and Learning}

12. Challenges for Work-Based Learning in Vocational Education and Training in the Nordic Countries

Christian Helms Jørgensen

13. Vocational Education and School to Work Transitions in Norway Torgeir Nyen, Asgeir Skålholt and Anna Hagen Tønder

14. Training for Innovation in Spain: Analysis of Its Effectiveness from the Perspective of Transfer of Training

Carla Quesada-Pallarès, Anna Ciraso-Calí, Pilar Pineda-Herrero and Àngela Janer-Hidalgo

15. Vocational Education and Training from the Perspective of Key Informants of Employer Associations in Spain: A Qualitative Analysis Rafael M. Hernández Carrera and Emilio Lucio-Villegas

16. Governing Vocational Education and Training in Europe Sandra Bohlinger

17. Conclusion: The Contested Field of Working and Learning

Sandra Bohlinger, Ulrika Haake, Christian Helms Jørgensen, Hanna Toiviainen and Andreas Wallo 


\title{
THE EUROPEAN SOCIETY FOR RESEARCH ON THE EDUCATION OF ADULTS (ESREA)
}

\begin{abstract}
ESREA is a European scientific society. It was established in 1991 to provide a European-wide forum for all researchers engaged in research on adult education and learning and to promote and disseminate theoretical and empirical research in the field. Since 1991 the landscape of adult education and learning has changed to include more diverse learning contexts at formal and informal levels. At the same time there has been a policy push by the European Union, OECD, UNESCO and national governments to promote a policy of lifelong learning. ESREA provides an important space for these changes and (re)definition of adult education and learning in relation to research, theory, policy and practice to be reflected upon and discussed. This takes place at the triennial conference, network conferences and through the publication of books and a journal.
\end{abstract}

\section{ESREA RESEARCH NETWORKS}

The major priority of ESREA is the encouragement of co-operation between active researchers in the form of thematic research networks which encourage interdisciplinary research drawing on a broad range of the social sciences. These research networks hold annual/biennial seminars and conferences for the exchange of research results and to encourage publications.

The current active ESREA networks are:

- Access, Learning Careers and Identities

- Active Democratic Citizenship and Adult Learning

- Adult Educators, Trainers and their Professional Development

- Between Global and Local: Adult Learning and Development

- Education and Learning of Older Adults

- Gender and Adult Learning

- History of Adult Education and Training in Europe

- Interrogating transformative processes in learning: An international exchange.

- Life-history and Biographical Research

- Migration, Ethnicity, Racism and Xenophobia

- Policy Studies in Adult Education

- Working Life and Learning

\section{ESREA TRIENNIAL EUROPEAN RESEARCH CONFERENCE}

In order to encourage the widest possible forum for the exchange of ongoing research activities ESREA holds a triennial European Research Conference. The conferences have been held in Strobl (1995), Bruxelles (1998), Lisbon (2001), Wroclaw (2004), Seville (2007), Linköping (2010) and Berlin (2013). 
ESREA

ESREA JOURNAL

ESREA publishes a scientific open access journal entitled The European Journal for Research on the Education and Learning of Adults (RELA). All issues of the journal can be read at www.rela.ep.liu.se. You can also find more information about call for papers and submission procedures on this website.

\section{ESREA BOOKS}

ESREA's research networks and conferences have led to the publication of over forty books. A full list, giving details of the various publishers, and the books' availability, is on the ESREA website. ESREA's current book series is published in co-operation with Sense Publishers.

Further information on ESREA is available at www.esrea.org

Emilio Lucio-Villegas

Barbara Merrill

Marcella Milana

Henning Salling Olesen 


\title{
SANDRA BOHLINGER, ULRIKA HAAKE, CHRISTIAN HELMS JØRGENSEN, HANNA TOIVIAINEN AND ANDREAS WALLO
}

\section{INTRODUCTION}

\author{
Working and Learning in Times of Uncertainty
}

Research on adult, professional and vocational education in a global world is timely (Farrell \& Fenwick, 2007). Globalisation and economic crises are the trends that most dramatically transform the social, political, economic and ecological spheres of our time and directly affect the everyday life of local communities and workplaces. Current challenges set compelling requirements for the working and learning of the members of communities. Over the past decades of adult, professional and vocational education research, researchers have increasingly addressed globalisation and its political, value-based and ethical underpinnings. Work-related learning and the workplace as an arena of learning and education is, in Fenwick's (2001) terms, a highly political space, in which the requirements of flexibility, specialisation, privatisation, and globalisation "change the nature and environment of work and the desires of workers" (ibid., p. 5). This book contributes to the current discussion on the global developments of working and learning in the fields of adult, professional and vocational education in Europe. These developments are full of paradoxes and contradictions, as Bratton et al. (2008) point out in their critical examination of workplace learning in advanced capitalist economies. It is therefore not an easy task to envision the future work and the learning options it will eventually offer to workers. We are living in times of uncertainty regarding the adult educational challenges on all societal levels of working and learning (Alheit, 2002/2004).

\section{CHALLENGES FOR WORKPLACE LEARNING}

The major paradox of the adult education policies in the work life context culminates in the concept of lifelong learning and its promises in the era of information and knowledge societies. Jarvis (2007) analyses how power in global society controls knowledge and information and the means of transmitting information; "[...] power operates in instrumental ways to further the ends of capital, even to suggesting that this power operates on occasions contrary to international agreements and certainly not always to the common good [...]" (ibid., p. 96). Historically, the move from the ideal of lifelong education to that of lifelong learning has implicated the shift from a societal policy of enhancing collective 


\section{S. BOHLINGER ET AL.}

qualifications and democratisation towards emphasising individual competencies and adaption to global capitalism (Barros, 2012; Milana, 2012).

In the practices of organisations such as multi-national companies, the compliance to multiculturalism norms to respect the diversity of personnel may paradoxically lead to decreased sensitivity to local conditions of learning (Toiviainen, 2015). Casey (2012) argues that workplaces in the West, especially large and corporate ones, have become less conducive to the expansion of worker participation and democratisation, and to lifelong educational and developmental opportunities for workers. "Many production organizations require workers' integration not through democratic citizenship, but through conformity to eliteestablished rules and systems" summarises Casey (2012, p. 317). Management studies have demonstrated that strong corporative integration reduces whereas adjustment to local needs increases teams' learning in multi-national companies (Zellmer-Bruhn \& Gibson, 2006). From this point of view, there is a contradiction between the management strategy and the teams' autonomy and empowerment for learning in organisations.

The paradoxes described above have far-reaching effects on individuals' learning. Globalisation brings new skills requirements to workers and managers in terms of cultural awareness and training. In line with Casey's argument, Martínez Lucio and Mustchin (2014) point out that these skills are "supposedly needed within global organizations and a global workforce, yet this can sometimes become an end in itself and be abused as a way of creating a more adaptable and therefore exploitable workforce and management" (ibid., p. 132).

The discussion on employees' skills requirements is entangled with organisations' human resource development (HRD) practices. Some scholars see HRD as a humaniser of the globalisation process in companies and argue for the creation of a strong corporate culture for learning (Marquardt et al., 2004). However, the expectations directed at HRD practices may be weakly grounded. Poell (2014) points out that HRD practitioners are distant from work sites and still have little influence on workplace activities carried out by employees and managers. In order to contribute to the creation of learning environments, HRD practitioners "[...] will first need to gain a foothold in the workplace - and, obviously, out of the training room and into the boardroom [...]" (Poell, 2014, p. 224f.). Alternatively, the first-line managers and supervisors will more and more take on the responsibility of the HRD functions when supporting employees' learning (Ellinger et al., 2011; Wallo, 2008).

\section{CHALLENGES FOR VOCATIONAL EDUCATION AND TRAINING}

In vocational education and training (VET), one of the core challenges is the matching between demand and supply, i.e. linking educational profiles and qualifications with labour market needs and positions (Dohmen, 2007; McIntosh, 2006; Psacharopoulos, 1994). The extent to which vocational education and training can provide a sound basis for an individual's personal, social and labourmarket-oriented development depends on a number of factors. Among these are the 
role and interests of institutional stakeholders, the share of general and vocational content in a VET programme, the (social, individual, monetary) value of VET qualifications in comparison with general/higher education qualifications, the structure of labour markets, education systems and welfare systems and national core beliefs of what makes a 'good' (vocational) education (and training) (Treimann, 1977; Vila, 2000).

This topic is closely linked with the implementation of occupational standards and their linkage to educational standards, alongside issues such as qualifications frameworks, recognition of prior learning, outcomes-based curricula, innovative teaching and training methods and developing and attracting skilled workers within and across countries (Brügelmann, 2003; Meyer, 2006). However, such standards (and benchmarks) are often not fully defined but rest on a sense of what someone should achieve if they complete a particular qualification. The ensuing lack of transparency may reduce the permeability between educational and occupational pathways. Global striving for more transparency, accessibility and permeability in education and in labour markets has led to numerous reforms in VET over the past decades. It is closely linked with equal opportunities to participate in VET and in the labour market and demands for new configurations of learning, working and leadership - a topic that is being discussed at the micro, meso and macro levels in this book.

Another core challenge for VET is the demographic change which impacts on most sectors and most labour market positions (e.g. CEDEFOP 2009; Kirpal 2012). Demographic changes not only refer to shrinking age cohorts and increasing numbers of ageing workers, but are also much related to migration and shifts in population structure and composition. In this respect, VET has to be adapted to non-traditional VET learner groups, shifting population groups, recognition of foreign qualifications and provision of additional or part qualifications to match national qualification structures (Cameron \& O'Hanlon-Rose, 2011; Tessaring \& Wannan, 2004).

An additional challenge stems from technological developments. Much has been researched on, for example, Web 2.0 (up to Web 4.0), cloud solutions, big data, smart office solutions, etc. But we know little about the long-term effects of these developments on individual learning, training and working processes and how VET can take advantage of these developments (Peters, 2007; Redecker et al., 2009). In other words: if, for example, smart office solutions become a common form of working in certain ways, then can VET trainees in office communication be prepared to face the challenges and changes stemming from flexible work space, working hours, communication structures and time frames? Research on this issue is in an early stage of development and again touches on the micro, meso and macro levels of research.

Last but not least, there is the question of governing and steering VET at regional, national and international levels, including the supranational level of the European Union. In a (European) era of lifelong learning, the borders between VET and other forms of learning and training unravel and the number and diversity of stakeholders, institutions and interests becomes barely manageable. Several 
researchers have linked EU integration policies to European and national VET policies (e.g. Dale, 2009; Fredriksson, 2003; West, 2012). In this respect, new forms of governing VET systems, including the European open method of coordination, benchmarking, co-operating across European borders and new framework programmes in all educational areas, promote better co-operation between countries and an improved match with the needs of the labour market, while maintaining the overall aim of personal development.

\section{CHALLENGES AT MICRO, MESO AND MACRO LEVELS}

The study of work and learning has become a meeting place for a number of diverse research disciplines, most significantly adult education, human resource development and vocational education and training, as discussed above. The research field of working and learning grows out of an interdisciplinary tradition that has made it dynamic and inventive - but also unclear and fragmented (Fenwick, 2010). The convergence of different disciplines of research in the field of working and learning is not just a result of the shared interests of researchers and research communities. It is first of all a result of profound changes in the actual practices under study. These changes are often summarised under the heading of globalisation. Globalisation weakens the traditional unequivocal association between learning and institutionalised education and redefines work to become an important source of learning, development and innovation (Martínez Lucio \& Mustchin, 2014). This is a reversal of a long history of substituting learning through the participation in work with formalised education. This edited volume explores why most types of work, as a result of globalisation, are being reconfigured in new ways, which at the same time requires learning and also provides opportunities for learning.

This book analyses challenges stemming from globalisation, uncertainty and economic crises and the impacts on working and learning at individual (micro), organisational (meso) and socio-political (macro) levels. We are not going to repeat the arguments already clearly stated in contemporary analyses, but will contribute by bringing evidence of the diversity of the practices and conditions of learning on different levels. Exploring the potential of current learning activities is the only way to avoid the idealisation of past adult educational practices and instead to try to understand future challenges. In other words, the question is how to renew the ideals of adult education in times of uncertainty in order to enhance democracy and peoples' empowerment through learning in and for work. Each of the contributions addresses two overall questions: How is working and learning affected by uncertainty and globalisation? And, in what ways do individuals, organisations, political actors and education systems respond to these challenges?

\section{Micro level}

At the micro level, the meaning and significance of work has changed over recent decades. Work is to a lesser extent mainly an economic necessity or a moral 
obligation and to a greater extent an element in individual identity and biographicity (Stroobants, Jans, \& Wildemeersch, 2001). For an increasing group of employees, work is expected to give not only the means for a living, but also individual meaning to their lives and, in addition, to offer opportunities for learning and personal development (Beck, 2002). The material values of industrial work have widely been supplemented with, or even displaced by, the cultural and relational values associated with professional work: autonomy, esteem and career prospects. Having opportunities for learning at work has become a social demand for the younger generations entering the labour market. At the same time, learning at work has become a requirement for remaining competitive and being attractive in the labour market (Sennett, 2006). Globalisation directly affects the lives of individuals and implies an acceleration of time and the accelerated rate of change driven by sharpened competition, new communication infrastructures and technological innovation (Rosa, 2013). As a consequence, learning to manage continuous change and uncertainty has become a key qualification in modern life and an important part of an individual's employability (Nilsson \& Ellström, 2012).

Part 1 of the book focuses on the micro level of working and learning, i.e., on understanding the learning process and the learners, leaders and trainers from an individual point of view, by, for instance, reflecting on the needs of individuals and their situations in transformation. Challenges discussed in the first part of the book capture changes brought by technological development and globalisation. It aims to understand configurations of learning when work expands globally and increasingly involves coordination and guidance across locations and cultures (Lam, 2006), and, more specifically, aims to overcome barriers in the leading and coordination of work assignments in globally distributed design networks. Another key question posed at the micro level is about developing an analytical framework to assess how people's engagement in specific historical and social work practices is significant to their development, maintenance or transformation of a learner identity (Desjardins, 2009). Such a framework is needed to grasp how different groups have distinctive conditions for forming a proactive learner identity and engage in lifelong learning, and thus meet the obligations prevalent in both national and transnational policies on lifelong learning (Biesta, 2006).

Another challenge put forth in this part of the book is the search for key predictors of successful learning transfer for vocational training, and to design training measures within continual vocational training according to these key predictors (Diesner \& Seufert, 2010). Also, an observation made of the learning process is that learning in internship seems to have moved towards expanding schooling (theoretical-based learning with explicit knowledge) and giving up principles of apprenticeship (acquisition of, for instance, tacit knowledge) in workplace learning (Dau \& Nielsen, 2011; Resnick, 1987). A discussion of this challenging phenomenon is also raised in this part of the book. Lastly, in the understanding of leadership, a review of previous research and theories shows that there are many notions of leadership that are taken for granted and that reduce the possibility of understanding the phenomenon (Alvesson \& Sveningsson, 2003). Many of these notions are related to the idea that globalisation, almost naturally, 
requires a new leadership (Northouse, 2013). Here, these understandings of leadership will be challenged.

In the first part of the book, Hanna Toiviainen addresses the cultural-historical configurations of learning that coordinators of distributed work draw on in the transformation of global work. Based on group and individual interviews, project meeting discussions and project documents gathered in a Finnish technology consulting and engineering company, the analysis in a wider organisational and theoretical-historical context reveals that learning increasingly forms an integral part of the primary goals of workplaces. Similarly, Sissel Kondrup's focus is on developing a theoretical framework for assessing individuals' engagement in historical and social work practices that are meaningful to the development, maintenance or transformation of their learner identities. Hence, she questions how different types of work provide conditions to form a proactive learner identity.

Michael Gessler and Anja Hinrichs also examine the individual perspective of learning processes by analysing the process of learning transfer. They present findings on how learning results gained off-the-job can be transferred into the job, including desired effects as well as side effects. Susanne Dau's chapter also emphasises the learning process. She analyses students' access to tacit and explicit knowledge in their development of professional knowledge. Gun Sparrhoff completes this section by addressing how notions of leadership as well as notions of desirable personalities of leaders have changed over time. This part of the book thus provides different points of view on the learning process including the perspectives of learners, leaders and trainers.

\section{Meso level}

At the meso level of organisations, professions and institutions, work has shifted from being a site of carrying out standardised tasks to an environment for learning and shared generation of new knowledge. A growing number of higher education graduates are entering the labour market and encounter problems of unemployment and underemployment (Scurry \& Blenkinsopp, 2011). After decades of expansion of formal education, and especially of higher education, more attention is now given to the significance of practice-based and tacit forms of knowledge developed and shared through participation in work. In recent decades business managers have taken greater interest in workplace learning to support the processes through which employees solve real-world problems, develop and share knowledge and improve their practices (Wallo et al., 2013; Warhurst, 2013). Organisations are under pressure to prepare for the uncertainties of the future and the growing instability of markets. This can be achieved not only by having employees with higher degrees and formal qualifications, but also by improving the ability of the organisation to learn from experiences. The benefit of learning in the workplace compared with formal qualifications and further training off-the-job is that it generates more contextual, specific and socially embedded knowledge at lower cost. Work can provide a rich and expansive learning environment, but current management practices often restrict the opportunities for learning by 
limiting time and space for experimenting, reflection, feedback and autonomy (Fuller \& Unwin, 2004). In traditional sociological theories a key characteristic that defines a profession is that it is built on a scientific knowledge base, like engineering or law, and legitimates credentials from a higher education institution (Freidson, 2001). But professional practice depends on much more than formal and evidence-based knowledge. Competent professional judgement also relies on embodied and intuitive know-how based on extended work experience (Eraut, 2000; Young \& Muller, 2014).

Against this background, the second part of the book focuses the meso level of working and learning by discussing sector-specific and organisational approaches to working and professional knowledge, leadership, competence development and learning in times of uncertainty. Challenges addressed in the chapters on the meso level are about the shift towards a historically new type of work and production called "co-configuration" (Victor \& Boynton, 1998). Here we address changes in learning and competence development that have only been analysed empirically on the level of mundane work actions to a small degree before (Normann, 2007; Prahalad \& Krishnan, 2008). Another challenge is about organisational changes due to new forms of governance and globalisation and the perceived importance of leadership to achieve successful implementation of these changes (Gill, 2002). A problematisation of leaders as strong change agents is discussed here.

Due to socio-economic changes, demographic trends and changing skills needs, another challenge that is put forth in this part of the book is the discussion on whether traditional vocational education and training (VET) or higher education programmes would be the most appropriate way to educate qualified professionals for important societal vocations (Jørgensen, 2004; Smeby, 2007). Another important theme is the challenge of attracting, recruiting, and retaining competent employees in sectors that have low status, high retirement measures, falling enrolment and low quality HR (Boswell et al., 2003; Cable \& Turban, 2003). These challenges raise the question of whether recognition of prior learning (RPL) is a beneficial tool to increase the employability of citizens at a relatively low cost (Andersson et al., 2013; Andersson \& Harris, 2006; Evans, 2000). This RPL model is argued to enable society to pay less in social benefits to unemployed people, as well as being beneficial for the individual, and both the prior learning and new learning of the individual.

Chapters in the second part of the book represent a broad range of branches including public services (police work), the automotive sector and the health sector (elderly care). Thomas Bäck starts with the question on how to structure police training programmes. He describes that an intense discussion of an academisation of police education in Sweden is going on at the same time as a major organisational reform of the police is launched. From this, he presents an empirical study of learning conditions for future career-relevant competencies in the vocational training of police officers. The following chapter by Ola Lindberg, Oscar Rantatalo and Ulrika Haake also provides an insight into organisational change in the police in Sweden. Elaborating on the methodology of practice theory, the authors analyse leadership performance, which expands the scope of analysis 


\section{S. BOHLINGER ET AL.}

from that of behaviour of leaders towards the exploration of the socio-material arrangements of leadership.

Kirsi Kallio provides another sectoral approach. She examines changes in learning in automation service work on the front line with customers in the provision of high-level automation software solutions. Her contribution provides a theoretical approach to shape historically new forms and methods of learning in automation service work. Dan Rönnqvist, Andreas Wallo, Peter Nilsson and Bo Davidson identify the challenges to structure qualification pathways and occupational profiles in the health care sector. Their approach is twofold: on the one hand, they address the consequences of demographic shifts in and for elderly care and on the other hand they identify the challenges for human resource practitioners in organisations to attract young people for jobs in this sector. Andreas Fejes and Per Andersson focus on the recognition of prior learning. In a qualitative study, they analyse how care workers, assistant nurses, local managers and teachers perceived their participation and work within an in-service training programme where recognition of prior learning was integrated. Their study examines the role that is ascribed to prior learning in the process of training and learning. They also contextualise the relationship between experience, learning and recognition.

\section{Macro level}

At the macro level, globalisation implies deregulation and an accelerated shift in the international division of labour, which has put especially low-skilled jobs under pressure in high-wage countries in Europe. Following the financial crisis, large groups of young people leaving the education system have been denied access to the labour market. In addition, the rapid shifts from old manufacturing to new knowledge-based industries and the growing skills requirements have repositioned a large share of the manufacturing workforce from the core of the economy to the margins of the labour market. A key answer to this challenge has been the upskilling of the adult workforce and measures to ensure that all young people complete an upper secondary education. In policies for adult education, emphasis has shifted from education for citizenship and equality to achieving employability and meeting skills requirements in the labour market. As a consequence, vocational education and training (VET) has attracted the attention of policy makers. Improving the VET system is seen as a way to improve the competitiveness of the national production system and at the same time as a way to provide education for young people who are not opting for higher education. Moreover, we have seen a renewed interest in the incorporation of work-based learning in all forms of postcompulsory education and in modern forms of apprenticeship, including those for adults (Fuller \& Unwin, 2014). This is expected to improve opportunities for employment and to increase the value of education in the labour market. At the macro level this represents a shift from providing social integration through education for citizenship to providing social integration through education for work and employability (Streeck, 2014). This shift is associated with a shift from a 
welfare state to a workfare state that combines activation measures with education and training to counter the effects of globalisation (Kananen, 2012). In the European context, this shift implies that the emphasis in the connection between work and learning is mostly on the adaptation of employees and job seekers to the current requirements of the labour market (Heyes, 2012). This is at odds with opportunities for a more far-sighted provision of broad skills to respond to the uncertainties and changes of work in the future.

Thus, Part 3 of the book addresses the macro level by analysing how to govern, structure and organise vocational, professional and adult education. One of the key challenges on the macro level is about integrating work-based learning into VET/apprenticeship. Questions are raised about how to integrate access to training placements, how to improve the quality of VET/training, and how to improve the image that apprenticeships have among young people and in the labour market (Fuller \& Unwin, 2009; Schaap et al., 2012). Another key theme in this part of the book addresses the effects of the financial crisis on access to stable full-time employment after completion of vocational education. The question of how changes in the labour market affect the transition to work of different social groups (gender, occupational) in different ways is also highlighted (Smith, 2009). Another challenge concerns future innovations. Organisations need to develop innovative capacity in order to face globalisation and uncertainty (Anderson et al., 2014; Fang et al., 2011). Innovation is considered as an alternative to offshoring production in order to reduce costs and increase profitability. Previous studies suggest that training of employees to become more innovative may facilitate the building of innovative capacity in organisations (Beugelsdijk, 2008; Shipton et al., 2006). Is this achievable?

Sometimes, government policies for adult education and training activities in companies have different goals (Forrester, 2007). One challenge raised in this section of the book is to deal with this. Another important question is to determine the role of employer associations in worker training and the workers' interest in it. Over previous decades, a European field of vocational education and training has emerged which - mostly through indirect rather than direct governance - has touched upon the core of this issue and has had decisive implications for national structures and the organisation of vocational education and training (Bohlinger, 2008). Against this background, the last challenge is to explore the European field of vocational education and training policy and the tensions this creates at the national level.

The first contribution in this part is written by Christian Helms Jørgensen. Focusing on the Nordic countries, he seeks to identify the best ways to provide youth with high-quality training and in doing so, he questions the structure of vocational education and training. His findings point out the importance of linking labour market needs with education, and at the same time qualifying for further studies by offering so-called hybrid qualifications, i.e., qualifications combining working and learning. Similarly, Torgeir Nyen, Asgeir Skålholt and Anna Hagen Tønder examine to what extent VET gives access to work. By analysing transition patterns for VET graduates in the Norwegian labour market, they conclude that 


\section{S. BOHLINGER ET AL.}

VET in general provides labour market-relevant skills and qualifications. Development of VET colleges could be a way of strengthening VET by bridging initial and further VET. Carla Quesada-Pallarès, Anna Ciraso-Cali, Pilar PinedaHerrero and Angela Janer-Hidalgo ask whether training for innovation in Spanish companies - resulting in innovative products or organisational/process-related changes - is more effective than other forms of training. The measure of effectiveness is the transfer of training, i.e., to what extent the trainees will apply their skills to innovate their work after training.

The chapter by Rafael Hernandez Carrera and Emilio Lucio-Villegas explores the irregularities observed in the Spanish vocational education and training (VET) involving both employer associations and trade unions. A critical analysis of employers' interests and engagement in VET reveals that vocational training is (partly) used to finance business organisations rather than to support adults' learning at work. In the final contribution, Sandra Bohlinger focuses on VET governance at the EU level and analyses who governs what, how and why in European VET policy. Referring to multiple examples in the field of (vocational) education, she answers the questions how, and in which ways, European stakeholders govern VET as a policy field that should be under the sovereignty of the member states. She goes on to identify the consequences of EU policy-making for shaping, structuring and organising VET at national levels.

\section{REFERENCES}

Alheit, P. (2002/2004). On a contradictory way to the 'learning society': A critical approach. In R. Edwards, N. Miller, N. Small, \& A. Tait (Eds.), Supporting lifelong learning: Volume III: Making policy work (pp. 30-49). New York: Routledge (Taylor \& Francis e-Library, 2004).

Alvesson, M., \& Sveningsson, S. (2003). The great disappearing act: difficulties in doing "leadership". The Leadership Quarterly, 14(3), 359-381.

Anderson, N., Potočnik, K., \& Zhou, J. (2014). Innovation and creativity in organizations a state-of-thescience review, prospective commentary, and guiding framework. Journal of Management, 40(5), 1297-1333.

Andersson, P., \& Harris, J. (Eds.). (2006). Re-theorising the recognition of prior learning. Leicester: NIACE.

Andersson, P., Fejes, A., \& Sandberg, F. (2013). Introducing research on recognition of prior learning. International Journal of Lifelong Education, 32(4), 405-411.

Barros, R. (2012). From lifelong education to lifelong learning: Discussion of some effects of today's neoliberal policies. European Journal for Research on the Education and Learning of Adults, 3(2), 119-134.

Beck, U. (2002). Individualization: Institutionalized individualism and its social and political consequences (Vol. 13). London: Sage.

Beugelsdijk, S. (2008). Strategic human resource practices and product innovation. Organization Studies, 29(6), 821-847.

Biesta, G. (2006). What's the point in lifelong learning if lifelong learning has no point? On the democratic deficit of policies for lifelong learning. European Educational Research Journal, 5(3/4), $160-180$.

Bohlinger, S. (2008). Kompetenzentwicklung für Europa. Opladen: Budrich. 
Boswell, W. R., Roehling, M. V., LePine, M. A., \& Moynihan, L. M. (2003). Individual job-choice decisions and the impact of job attributes and recruitment practices: A longitudinal field study. Human Resource Management, 42(1), 23-37.

Bratton, J., Helms Mills, J. C., Pyrch, T., \& Sawchuk, P. (2008). Workplace learning: A critical introduction. Toronto: University of Toronto Press.

Brügelmann, H. (2003). In fünf Jahren ... Über Kerncurricula, Bildungsstandards und Leistungstests. Neue Sammlung. Vierteljahreszeitschrift für Erziehung und Gesellschaft, 2, 235-238.

Cable, D. M., \& Turban, D. B. (2003). The value of organizational reputation in the recruitment content: A brand-equity perspective. Journal of Applied Social Psychology, 33(11), 2244-2266.

Cameron, R., \& O’Hanlon-Rose, T. (2011). Global skills and mobility challenges and possibilities for VET: A cross-border cross-sectoral case study. International Journal of Training Research. Special Issue: The Future of Technical and Vocational Education and Training: Global Challenges and Possibilities, 9(1-2), 134-151.

Casey, C. (2012). The learning worker, organizations and democracy. In D. W. Livingstone \& D. Guile (Eds.), The knowledge economy and lifelong learning: A critical reader (pp. 317-334). Rotterdam: Sense.

CEDEFOP (2009). Implications of demographic change for vocational education and training in the $E U$. Luxembourg: Office for Official Publications of the European Communities.

Dale, R. (2009). Studying globalisation and Europeanisation in education: Lisbon, the open method of coordination, and beyond. In R. Dale \& S. Robertson (Eds.), Globalisation and Europeanisation in education (pp. 121-140). Oxford: Symposium Books.

Dau, S., \& Nielsen, G. (2011) Vidensgrundlaget i professionsuddannelserne - kognition som fundament eller forplumring? Gjallerhorn Tidsskrift for professionsuddannelser, 14, 70-80.

Desjardins, R. (2009). The rise of education as an economic policy tool: some implications for education policy research. In R. Desjardins, \& K. Rubenson (Eds.), Research of vs. research for education policy - In an era of transnational policy-making (pp. 5-18). Saarbrücken: Verlag Dr. Müller.

Diesner, I., \& Seufert, S. (2010). Trendstudie 2010: Herausforderungen für das Bildungsmanagement in Unternehmen. St Gallen: SCIL Swiss Centre for Innovations in Learning.

Dohmen, D. (2007). Economics of vocational education and training: Introduction and overview. Berlin: Institute for Education and Socio-Economic Research and Consulting.

Ellinger, A. D., Hamlin, R. G., Beattie, R. S., Wang, Y.-L., \& McVicar, O. (2011). Managerial coaching as a workplace learning strategy. In R. F. Poell, \& M. van Woerkom (Eds.), Supporting workplace learning: Towards evidence-based practice (pp. 71-88). Dordrecht: Springer.

Eraut, M. (2000). Non-formal learning and tacit knowledge in professional work. British Journal of Educational Psychology, 70(1), 113-136.

European Commission (2010). An agenda for new skills and jobs: A European contribution towards full employment. Strasbourg: European Commission.

Evans, N. (Ed.). (2000). Experiential learning around the world: Employability and the global economy. London: Jessica Kingsley.

Fang, S., Chou, C., Yang, S., \& Tsai, F. (2011). Relationship learning and innovation: The role of relationship-specific memory. Industrial Marketing Management, 40(5), 743-753.

Farrell, L., \& Fenwick, T. (2007). World yearbook of education 2007: Educating the global workforce: Knowledge, knowledge work and knowledge workers. New York: Routledge.

Fenwick, T. (2001). Tides of change: New themes and questions in workplace learning. New Directions for Adult and Continuing Education, 2001(92), 3-18.

Fenwick, T. (2008). Workplace learning: Emerging trends and new perspectives. New Directions for Adult and Continuing Education, 2008(119), 17-26.

Fenwick, T. (2010). Workplace 'learning' and adult education. Messy objects, blurry maps and making difference. European Journal for Research on the Education and Learning of Adults, 1(1-2), 79-95.

Forrester, K. (2007). Exploring understandings of labours, learning and democracy: A British case study. In E. Lucio-Villegas, \& M. C. Martínez, (Eds.), Adult learning and the challenges of social 


\section{S. BOHLINGER ET AL.}

and cultural diversity: Diverse lives, cultures, learning and literacies (pp. 63-76). Proceedings of the $5^{\text {th }}$ ESREA European Conference, Vol. 3.

Fredriksson, U. (2003). Changes of Education Policies within the European Union in the Light of Globalisation. European Educational Research Journal, 2(4), 522-546.

Freidson, E. (2001). Professionalism, the third logic: On the practice of knowledge. Chicago: University of Chicago press.

Fuller, A., \& Unwin, L. (Eds.). (2014). Contemporary apprenticeship: International perspectives on an evolving model of learning. New York: Routledge.

Fuller, A., \& Unwin, L. (2009). Change and continuity in apprenticeship: The resilience of a model of learning. Journal of Education and Work, 22(5), 405-416.

Fuller, A., \& Unwin, L. (2004). Expansive learning environments: Integrating organisational and personal development. In H. Rainbird, A. Fuller, \& A. Munro (Eds.), Workplace learning in context (pp. 126-144). New York: Routledge.

Gill, R. (2002). Change management - or change leadership? Journal of Change Management, 3(4), $307-318$.

Heyes, J. (2012). Vocational training, employability and the post-2008 jobs crisis: Responses in the European Union. Economic and industrial democracy, 34, 291-311.

Jarvis, P. (2007). Globalisation, lifelong learning and the learning society: Sociological perspectives. London: Routledge.

Jørgensen, C. H. (2004). Connecting work and education: Should learning be useful, correct or meaningful? Journal of Workplace Learning, 16(8), 455-465.

Kananen, J. (2012). Nordic paths from welfare to workfare: Danish, Swedish and Finnish labour market reforms in comparison. Local Economy, 27(5-6), 558-576.

Kirpal, S. (2012). The contribution of European Programmes to social change. In G. Elliot, \& C. Fourali (Eds.), Education and social change. Connecting local and global perspectives (pp. 62-74). London: Continuum.

Lam, W. S. E. (2006). Culture and learning in the context of globalization: Research directions. Review of Research in Education, 30, 213-237.

Marquardt, M., Berger, N., \& Loan, P. (2004). HRD in the age of globalization: A practical guide to workplace learning in the third millennium. New York: Basic Books.

Martínez Lucio, M., \& Mustchin, S. (2014). Training and workplace skills in the context of globalization: new directions and discourses in skills. In M. Martínez Lucio (Ed.), International human resource management: An employment relations perspective (pp. 118-136). London: Sage.

McIntosh, S. (2006). Further analysis of the returns to academic and vocational qualifications. Oxford Bulletin of Economics and Statistics, 68(2), 225-251.

Meyer, R. (2006). Bildungsstandards im Berufsbildungssystem. Ihre Relevanz für das berufliche Lernen zwischen Anspruch und Wirklichkeit. Zeitschrift für Berufs- und Wirtschaftspädagogik, 102(1), 4963.

Milana, M. (2012). Political globalization and the shift from adult education to lifelong learning. European Journal for Research on the Education and Learning of Adults, 3(2), 103117.

Nilsson, S., \& Ellström, P.-E. (2012). Employability and talent management: Challenges for HRD practices. European Journal of Training and Development, 36(1), 26-45.

Normann, R. (2007). Reframing business: When the map changes the landscape. Chichester: John Wiley \& Sons.

Northouse, P.G. (2013). Leadership: Theory and practice (6 ${ }^{\text {th }}$ ed.). Los Angeles: Sage.

Peters, K. (2007). m-Learning: Positioning educators for a mobile, connected future. International Review of Research in Open and Distance Learning, 8(2), http://www.irrodl.org/index.php/ irrodl/article/view/350/894

Poell, R. (2014). Workplace Learning. In N. E. Chalofsky, T. S. Rocco, M. Lane Morris (Eds.), Handbook of human resource development (pp. 215-227). Somerset, NJ: Wiley. 
Prahalad, C. K., \& Krishnan, M. S. (2008). The new age of innovation: Driving cocreated value through global network. London, New York: McGraw-Hill.

Psacharopoulos, G. (1994). Returns to investment in education: A global update. World Development, 22(9), 1325-1343.

Redecker, C., Ala-Mutka, K., Bacigalupo, M., Ferrari, M., \& Punie, Y. (2009). Learning 2.0: The impact of Web 2.0 innovations on learning and training in Europe. Final report. Luxembourg: Office for Official Publications of the European Communities.

Resnick, L. B. (1987). The 1987 presidential address: Learning in school and out. Educational Researcher, 16(9), 13-54.

Rosa, H. (2013). Social acceleration: A new theory of modernity. New York: Columbia University Press.

Schaap, H., Baartman, L., \& de Bruijn, E. (2012). Students' learning processes during school-based learning and workplace learning in vocational education: A review. Vocations and Learning, 5(2), 99-117.

Scurry, T., \& Blenkinsopp, J. (2011). Under-employment among recent graduates: A review of the literature. Personnel Review, 40(5), 643-659.

Sennett R. (2006). The culture of the new capitalism. Cambridge: Polity Press.

Shipton, H., West, M. A., Dawson, J., Birdi, K., \& Patterson, M. (2006). HRM as a predictor of innovation. Human Resource Management Journal, 16(1), 3-27.

Smeby, J. C. (2007). Connecting to professional knowledge. Studies in Higher Education, 32(2), 207224.

Smith, D. I. (2009). Changes in transitions: The role of mobility, class and gender. Journal of Education and Work, 22(5), 369-390.

Streeck, W. (2014). Buying time: The delayed crisis of democratic capitalism. New York: Verso Books.

Stroobants, V., Jans, M., \& Wildemeersch, D. (2001). Making sense of learning for work. Towards a framework of transitional learning. International Journal of Lifelong Education, 20(1-2), 114-126.

Tessaring, M., \& Wannan, J. (2004). Vocational education and training - Key to the future. Luxembourg: Office for Official Publications of the European Communities.

Toiviainen, H. (2015). Learning interventions at global workplaces. In T. Hansson (Ed.), Contemporary approaches to activity theory: Interdisciplinary perspectives on human behavior (pp. 214-227). Hershey, PA: IGI Global.

Treiman, D. J. (1977). Occupational prestige in comparative perspective. New York: Academic Press.

Victor, B., \& Boynton, A. C. (1998). Invented here: Maximizing your organization's internal growth and profitability. Boston, MA: Harvard Business School Press.

Vila, L. E. (2000). The non-monetary benefits of education. European Journal of Education, 34(1), 2132.

Wallo, A. (2008). The leader as a facilitator of learning at work. A study of learning-oriented leadership in two industrial firms. Dissertation. Linköping: Linköping Studies in Behavioural Science.

Wallo, A., Ellström, P.-E., \& Kock, H. (2013). Leadership as a balancing act between performance-and development-orientation: A study of managers' and co-workers' understanding of leadership in an industrial organisation. Leadership \& Organization Development Journal, 34(3), 222-237.

Warhurst, R. P. (2013). Learning in an age of cuts: Managers as enablers of workplace learning. Journal of Workplace Learning, 25(1), 37-57.

West, J. (2012). The Evolution of European Union Policies on Vocational Education and Training. LLAKES Research Paper 34, published by the Centre for Learning and Life Chances in Knowledge Economies and Societies at: http://www.llakes.org

Young, M., \& Muller, J. (Eds.). (2014). Knowledge and the professions. London and New York: Routledge.

Zellmer-Bruhn, M., \& Gibson, C. (2006). Multinational organization context: Implications for team learning and performance. Academy of Management Journal, 49(3), 501-518. 
S. BOHLINGER ET AL.

Sandra Bohlinger

Faculty of Education

Dresden University of Technology, Germany

Ulrika Haake

Department of Education

Umeå University, Sweden

Christian Helms Jørgensen

Department of Psychology and Educational Studies

Roskilde University, Denmark

Hanna Toiviainen

Center for Research on Activity, Development and Learning (CRADLE)

Institute of Behavioural Sciences, University of Helsinki, Finland

Andreas Wallo

Department of Behavioural Sciences and Learning

Linköping University, Sweden 
PART 1

MICRO LEVEL OF WORKING AND LEARNING 



\section{CONFIGURATIONS OF LEARNING IN GLOBAL WORK}

\section{INTRODUCTION}

The engineering design activity of an established Finnish forestry consulting and engineering company was reorganised during the first decade of the 2000s. By distributing the engineering design to its global units, the company was able to implement advanced ICT and digital design environments in a cost-effective way. At the same time, however, this reorganisation markedly changed the company's strong tradition of co-located teams. The work had been carried out through intensive interaction among the engineering design team members, including the coordinators from the project task force and the designers. Ongoing co-operation with researchers led to a new research initiative in which the project managers and the researchers agreed to collect data from the company's first globally distributed engineering design project. The topic of the research was not the mastery of an international project activity, which represented the core competence of the company. Rather, both the researchers and practitioners were interested in exploring how to learn new network-based work practices (Toiviainen et al., 2012). The company was designing and building a pulp and paper factory for a customer. At the beginning of the project, tasks that had normally been casual design issues now became issues of learning, as the coordinators in Finland had to rethink the conditions in which they interacted with and guided the remote designers in the Chinese office.

In this situation, I became interested in a specific question: What are the cultural-historical configurations of learning that coordinators of distributed work draw on in the transformation to global work? Configurations of learning illustrate how people draw on multiple knowledge sources while making sense of a new situation. These sources may represent an advanced concept formation (Engeström et al., 2005) or vague ideas about future, all of which I will refer to as configurations. Understood in this way, configurations are best analysed by means of a multi-method approach. In this chapter I will present such a method, apply it to the introductory case and, finally, discuss the configurations of learning in global work in the methodological framework. 


\section{METHODOLOGY AND DATA}

This chapter revisits three methodological perspectives for analysing the configurations of learning: theory history, object history and actual-empirical analysis. The methodological principle of combining these three different sources of data to analyse change and learning is based on Developmental Work Research and the theory of expansive learning (Engeström, 1987). The methodology represents the research tradition of cultural-historical activity theory (Chaiklin et al., 1999; Cole \& Hatano, 2007; Engeström et al., 1999; Toiviainen \& Engeström, 2009). The aim is to analyse concrete and local human activities in a developmental perspective, searching for "incorporate historicity and developmental judgment into activity-theoretical analyses, yet [taking] fully into account the diversity and multiplicity inherent in human activities," as Engeström (1999, p. 28) puts it.

The theory-historical, object-historical and actual-empirical data are analysed in their own right, yet the findings of each analysis become meaningful by interrelating them. Theory history and object history trace the historical-genetic origins of the present activity, thus expanding the interpretation of the actualempirical findings. Actual-empirical knowledge, even if not equally articulated, expands historical understanding. Together they form a framework to reveal the developmental contradictions and learning challenges of the present activity and to envision a culturally more advanced activity to be pursued through learning. I will use this framework heuristically to explore the configurations and developmental visions of learning in the face of globalisation. Simultaneously, I admit that applying this framework in the analysis of systemic contradictions would require more detailed data about the case company's activity.

By theory-historical configurations of learning, I refer to the concepts and conceptions of learning that are culturally shared and available when the members of a given community make sense of change and the learning challenges involved in that change. The data is drawn from general knowledge sources of a given domain, in this case, learning and learning theories, and from specific professional knowledge, here mainly of engineering learning. For the purposes of my presentation, the data is selective and the findings hypothetical, as I will point out in the analysis.

Object-historical configurations of learning stem from the cultural history of the activity shared by the members of an organisation. They include ideas concerning what needs to be learnt, what the conditions for learning are, and how learning takes place in a specific company. My data consists of historical knowledge on the case company's activity drawn from reports, historical studies and storytelling in interviews that address the object of learning at different periods of time.

Actual-empirical configurations of learning appear, when so interpreted, in the present actions and accounts of a given activity related to learning. Data is collected by recording actions and interactions, and by interviewing participants concerning their conceptions, however vague and unorganised, of the learning challenges emerging in the focal activity. My research colleague and I used 
ethnographic methods whenever possible and obtained a rich constellation of data comprising group and individual interviews, project meeting discussions and project documents. I am aware that the use of ethnography and its possibilities and limitations in engineering and network studies has been discussed (e.g., Kunda, 2006; Vinck, 2003; Wittel, 2000).

In this analysis, the actual-empirical data is drawn from a group interview conducted at the beginning of the project, during which the participants expressed their concerns about the conditions of learning in a globally distributed engineering design project. In order to capture the entire range of the potential configurations of learning, I decided to limit the unit of data to a single utterance by a speaker. Even though an utterance represents one speaker at a time, in this group discussion utterances were often collectively produced. In addition, one speaker may have expressed several types of configurations, which is typical for peoples' accounts when influenced by change and uncertainty about the future. Utterances that in my interpretation addressed learning issues were selected for the analysis, and representative examples will be provided in the actual-empirical analysis.

\section{THEORY-HISTORICAL CONFIGURATIONS OF LEARNING}

When the engineering design experts found themselves in a new situation that involved cross-cultural guidance, they made sense of the new task by discussing the potential of training and learning, and the problems involved. This sense making was closely connected and subordinated to the requirements of the project activity and engineering design. Although the sense making was not inspired by an academic interest in learning theories, it would be misleading to think that theoretical knowledge is not mediated to and used in non-educationalists' work. We know that laypersons may have well-formed conceptions of psychological constructs relevant to their everyday world, such as "intelligence" (Sternberg et al., 1981). Their "implicit theories" may in many respects resemble those of experts regarding their assessments of a given concept, in this case, intelligence. ${ }^{1}$

Regarding the concept of learning, Collin's (2002) analysis revealed that Finnish development engineers' conceptions of their learning at work, based on work experiences and social interactions in the workplace, were quite elaborate and versatile. The learning-theoretical sources of their conceptions were not in the focus of Collin's analysis. However, when informing the employees of the purpose of the interview - "to find out about their experiences and conceptions of learning at work" (ibid., p. 139) - the researcher already presupposes a shared understanding of learning as a theoretical category. I emphasise that learning is one of the culturally shared concepts that laypersons are able to articulate based on their experiences and that these articulations are mediated by the theory history of learning and education.

Drawing from my own experience of encounters at workplaces, people recognise the difference between (behaviourist) rote learning (in Finland, learning by chanting "a pike is a fish") and the (cognitive-constructionist) principle of making the object of learning meaningful in a given context (learning by 


\section{H. TOIVIAINEN}

"understanding why"). Another example is my colleague's introduction of "distributed intelligence" (cf. Fischer \& Konomi, 2007) as a source of knowledge, which was welcomed with amusement by a group of engineers, who immediately captured the shift from an individual-mentalist to a collective-social understanding of learning in a networked technology-mediated activity.

In the literature, the history of learning theories has mainly been analysed as intertwined in educational activities. Koschmann (1996) shows how computerassisted instruction in the 1960s was based on a behaviourist approach, which, he states, many commercial educational software products still represent. The next phase, in roughly the 1970 s, represented by intelligent tutoring systems based on a cognitivist philosophy, whereas in the1980s the teaching of the Logo programming language took a constructivist approach. Computer-supported collaborative learning (CSCL) during and after the 1990 s on was motivated by social constructivist and dialogical theories (ibid.).

Even though the emergence and dominance of major theoretical paradigms date back to certain historical periods, a cultural-historical interpretation is that these theories and models continue their life as historical layers in the conceptions of people and communities. Engeström et al. (2005) analysed collaborative concept formation as a complex fabric of vertical shifts between declared (theoretical, topdown) concepts and experienced (everyday, bottom-up) concepts, and horizontal shifts between different co-existing and controversial concepts defining the object in question. In such concept formation "developmentally earlier conceptualizations typically continue to coexist with developmentally later conceptualizations meant to replace the earlier ones" (ibid., p. 56).

In sum, I argue that the history of learning theories is mediated to present-time learning configurations as layers ranging, generally speaking, from behaviourist to constructivist and socio-cultural thinking. Budding theories probably coexist with more familiar concepts of learning and may not yet be strongly represented in work communities. A researcher may expect the ideas of rote learning, trial and error, apprenticeship, participation, and cognitive "understanding why" to appear more often than recent ideas of creativity and innovativeness or distributed technologymediated knowledge creation (Hakkarainen, 2009). A practitioner may use learning theoretical findings to realise that a chosen conception has implications for further actions - what is possible and desirable, and what is not. For example, to what extent does the adopted learning concept take into account the learner's agency and volition?

\section{OBJECT-HISTORICAL CONFIGURATIONS OF LEARNING}

A major transformation of activity and the need for learning do not necessarily result in employees reflecting on their learning philosophy, but certainly encourage reflection on the learning traditions and practices of the company. Employees may literally feel the discrepancy between the deeply rooted procedures of the firm and the new requirements. In order to understand their feelings and difficulties, we 
need object-historical knowledge of the activity and learning practices specific to their work.

The case company is a leading actor in forestry consulting and engineering in Finland. ${ }^{2}$ Globalisation in this company dates to the beginning of the 1980 s, when the company's engineering activity had spread throughout the world through its subsidiaries. Especially important in this process was its original strategy of combining its global activity with flexible adaptation to local conditions. E-mail, telefax and computer-aided design (CAD) systems were adopted in the first half of the 1980s to support both globalisation and the local presence.

The company's customer relationships are described as longstanding and cooperative based on the company's flexibility as a service provider. Finnish senior experts are in charge of launching big projects, but they are expected to delegate agency to local experts and avoid aggressive management. According to one of the analyses, the cross-cultural experiences of the company's experts have been a source of hero stories serving as examples to new consultants. This kind of individualism may be a remnant of the culture of a family-owned firm that gradually transformed into a globally operating consortium.

A new wave of globalisation started in the 2000s when the company's core process of engineering design was distributed worldwide. The company sent senior experts to developing engineering units in China and elsewhere, applying the same practice of local presence to the design process as it had applied to the management of local building sites. The worldwide distribution of design tasks in a single project was in this way possible, but, at the same time, it violated another practice, the co-location of the taskforce in charge of project planning. A research report describes that the task forces formed at the beginning of the project bring together senior experts and managers who plan the basic approach and the concrete steps for a large-scale project. At this stage, co-located work is seen as necessary. A nondistributed nature of this company's strategy in its core business processes is emphasised. This refers to the tradition of co-location and face-to-face interaction between the project planning taskforce and the design team whose work the taskforce supervises.

The role of tools and technologies has been and continues to be central in the definition of expertise in the case engineering company. The use of paper, pen and a drawing board has changed to a virtual design environment, which was developed over the years for internal use to manage the totality of the engineering design. That environment is currently being offered to customers as a business concept. The company has throughout its history focused resources on the development of its own software applications. The virtual design environment is said to serve all phases of a project, from design to installation and maintenance. It is a platform for a $3 \mathrm{D}$ model, a database and documentation with a web-based user interface.

Certain tasks and professions have disappeared with the advancement of technology, such as drafters and copyists, and correspondingly, the use of new software applications has brought new tasks that workers have not been initially trained for, such as drafting for mechanical designers. The introduction of novel 


\section{H. TOIVIAINEN}

technologies and applications caused resistance from workers in the company's history. As new tasks could be allocated to people instead of laying off staff, the resistance was overcome. Today, the experts of the company face a paradox: as an outcome of long-term development, the tools supporting work in a global network are better than ever. Simultaneously, as a result of global networking, the end of expert work and, with it, the education of new generations of designers in the headquarters is their greatest concern (Toiviainen, 2015).

Object-historically, the case company's early internalisation and adoption of ICT; the local presence, individualism and co-location of design activity; the development of firm-specific tools; the changing expertise related to the use of new tools; and global networking are cultural notions I interpret as crucial for company's configurations of learning. In the globalisation process, cultural practices and configurations of learning are in mutual transformation, effecting and moulding each other.

\section{ACTUAL-EMPIRICAL CONFIGURATIONS OF LEARNING}

The globalisation of engineering design compelled the members of the task force to reflect on the various alternatives for and barriers to performing their tasks as coordinators in a distributed design network (Toiviainen et al., 2012; Toiviainen, 2015). As the guidance of the design engineers' work was their main task, their discussion touched on learning in essential ways. I discerned four different configurations, varying from strict control to the possibilities of networking and change. To highlight the differences in these configurations (learning-theoretically and object-historically), I present short descriptions and illustrative group interview excerpts of each type (see the section "Methodology and Data").

\section{Learning under control}

When operating in a distributed network in which new employees are only starting to familiarise themselves with the project's tasks, it is best to keep the tasks restricted and well-framed. Control is needed to ensure that everyone follows the processes and uses the tools in the way they are meant to be used in the company. The guidance of new engineers in cross-cultural units is experienced as extra work that burdens the coordinator.

We just need to search for a model [from the database] and tell the Chinese, do it like that!

The concern is whether they know the tool and use it in the same way. Written instructions are necessary.

Networking adds to the total work load. When [a design is] made in China and [city in Finland], someone has to take control of the work. 


\section{Learning through meaningful work}

Instructing new design engineers entails explaining, giving reasons and opening a broader view of the design task. The effects of control and giving direct commands are contrary to learning. Instruction in a cross-cultural network adds to the coordinators' work load, not primarily because of the need for control, but because of the lack of proper instruction tools. E-mail messages do not replace the strong tradition of oral instruction and face-to-face motivation work.

If you just comment and send that back, it is not instruction. But you have to explain why this is done like this, and in that way the next designer [generation] is produced.

There are many who will not accept the command "Do it like this!" They say that this guy is bossing me around. There should be an instruction attached explaining why. That is missing from the e-mail.

\section{Learning through participation}

Acquiring the expertise that has accumulated in the company for decades requires intense local interaction between experienced and novice employees. This knowledge is company specific and built into the design tools. Emphasising company-specific local interaction, a long learning time and situatedness highlights the problems of learning in a cross-cultural newly emerged and distributed network. The project coordinators' unwillingness to transition from an old practice to a new one latently present in two former configurations is articulated below.

It would be much easier for me to work with the guys I know; I know what they can stand and that the department is located nearby. I get no added value from working with some remote team.

It's an illusion that we can take any one engineer to do this work. It requires two years' experience at a minimum to understand the knowledge that is inside the design tool.

Mastering the tools is one aspect, but real mastery requires many years' experience to be able to do this work.

So much experience, knowledge and insight are incorporated in the tool that

it cannot be learnt anywhere but in [this company].

\section{Learning in and for distributed technology-mediated work}

Work is changing and changes the practices of instruction and learning. Networked design tools support the new design engineers' learning in a way that in the long run makes top-down control and centralised coordination unnecessary. What this learning in and for change might be is not formulated. Rather, the project coordinators' utterances comment on the three former learning configurations and articulate the need for change. 


\section{H. TOIVIAINEN}

We have one model, and it is possible to design in different offices. Even every hour we can print out what the guys in China or elsewhere have designed and we can comment on that. This is the advantage that has led to networking.

The result will be that when we have been working together for a while, we will not need extensive control.

Our coordination of work is too Helsinki centred.

Altogether, I discerned four actual-empirical configurations of learning labelled in terms of control, meaningfulness, participation and change. I will next discuss the findings by interrelating the theory-historical, object-historical and actual-empirical configurations of learning.

\section{DISCUSSION}

The transformation to global work does not follow a single developmental line. For the participants at workplaces it opens up various potential directions and configurations. For researchers global work is a case of adults' learning in times of uncertainty and opens up multiple research perspectives. I wanted to pay attention to the configurations of learning when work expands globally and increasingly involves coordination and guidance across locations and cultures. Experienced specialised experts, the engineering design coordinators, made sense of their work and their encounters with new designers. This sense making could partly be interpreted in the light of different cultural-historical sources of learning-related knowledge. I analytically discerned theory-historical, object-historical and actualempirical sources and pointed out that each of these, separately and inter-relatedly, mediate the configurations of learning that orient the practitioners and may have an impact on the future course of action.

First, by interpreting the four actual-empirical configurations of learning in the light of culturally mediated theory history, we recognise orientations towards behaviouristic control, a cognitivist emphasis on meaningfulness, a socio-cultural participation approach, and technology-mediated distributed learning. These were the conceptual resources that the project coordinators implemented when making sense of and enhancing the distant novices' learning in the globalisation. Even in this limited research setting, the theoretical knowledge of the learning potential residing in distributed ICT-mediated work was still embryonic and not strongly represented in the practitioners' conceptions.

Secondly, interpreted object-historically, the actual-empirical configurations of learning culminated in the coordinators' emphasis on learning through participation. This emphasis was deeply embedded in the culture and learning practices of the company. Engineering design had been organised locally, based on an intensive interaction between the coordinators (typically experienced senior workers) and the designers (both experts and novices). In this frame of reference, the change to globally distributed work appeared as a threat to the continuity of 
activity. Global work formed a threat socially and spatially. But more than that, it threatened the object of activity, engineering design and consultation for the forest industry, which was experienced as distributed and uncontrollable by the project coordinators. The history of co-location, the development of company-specific technology and learning through participation are the key to understanding other configurations of learning, in other words, the coordinators' need for a high level of control, the emphasis on meaningfulness and the somewhat sceptical attitude towards networking technology and tools.

I have discussed how the theory history and the object history add to the interpretation of the actual-empirical findings. I have shown that theory-historically the views of technology-mediated learning were still relatively weak, and objecthistorical knowledge illuminates why the coordinators were suspicious of the learning possibilities in the globally distributed engineering design work. The final question remains of whether the actual-empirical findings add to the theory history and object history by outlining current and future developments. The data is too limited to present far-reaching results, but I will discuss some relevant points in my conclusions.

\section{CONCLUSION}

Fuller and Unwin (2005) have pointed out that workplace learning is not the primary goal of the workplace but a by-product of the activities and relationships involved in the production of goods or services. "It follows that any analysis of learning at work should be located within a wider analysis of the organizational context within which it is embedded" (Fuller \& Unwin, 2005, p. 24). I argue that the wider analysis of an organisational context, which in my terms belongs to object history, reveals that learning increasingly forms an integral part of the primary goal of workplaces. This is very visible in co-configuration (not to be confused with the configurations analysed here) work based on continuous learning (Victor \& Boynton, 1998; Engeström, 2004; Kallio, in this volume). "[W]ithin coconfiguration work, the organization and its members need to learn constantly from interactions between the user, the product/service, and the producers" (Engeström, 2004, p. 16; italics added). I further argue that the work of experienced project coordinators in a global network is an example of a coconfiguration setting that entails deepening insight in learning and instruction across locations and cultures. It is to some extent surprising that the learningtheoretical underpinnings, in my terms the theory-historical origins, of workers' conceptions have not attracted researchers' attention.

The central finding regarding learning configurations was the project coordinators' strong emphasis on co-located work and learning through participation. Theoretically, this is in line with the notion held by researchers on learning as participation that "has become the dominant approach to understanding workplace learning" (Fuller \& Unwin, 2005, p. 24). The original notion of legitimate peripheral participation by Lave and Wenger (1991) has been criticised, but the foundational idea of participation as a theoretical concept and as identified 


\section{H. TOIVIAINEN}

in employees' actual-empirical accounts on learning is generally still accepted. I feel it therefore risky to suggest, as my actual-empirical findings are quite tentative, that the participation approach to learning is problematic in the global coconfiguration type of work. Participation is theory-historically so deeply rooted in local communities that it seems necessary to look for new concepts for global work. $^{3}$

One example of a new concept is the new understanding given to the universality and cosmopolitanism in human beings' lives. Does this implicate giving up cultural specificity and situatedness of learning, that is, learning as participation? Lam (2006) has proposed that learning within the globalised context takes place "in the form of intercultural practices wherein young people draw upon and reshape diverse cultural materials, develop multisite and multilayered identifications, and navigate the overlapping and dividing lines among cultures, ethnicities, languages and nations" (ibid., p. 228). The national project of schooling and education is challenged by new kinds of knowledge and subject formation. Quoting Lam (2006, p. 230),

formulation of cosmopolitan identity seeks to displace the elitist, globetrotting, frequent-flyer image of cosmopolitanism and signal the many kinds of cosmopolitan experiences on the ground practiced by ordinary people who have developed various kinds of globalized visions as a result of conditions such as forced or voluntary migration of labor; exposure to transnational media; border-crossing exchanges of an educational, corporate or bureaucratic nature; and contact with cultural 'others' in historically insulated locales.

In contrast to this kind of universalism, one trend in the research of workplace learning is to specially focus on the dominance of globalisation and the loss of cultural relevance (Cairns \& Malloch, 2011). According to critics, the growing global uniformity in education strengthens the hegemony of global elites (Spring, 2008, p. 352). In adult education, "global discourses on education and knowledge economy changed the earlier humanist vision of lifelong learning to one focused on the ability of workers to adapt to a changing world of work" (Spring, 2008, p. 340). Concerns about the loss of cultural identity or the rise of education that serves adaptation to neo-liberal market forces are not without foundation. However, contrasting humanist lifelong learning against the learning challenges of the changing world of work does not serve the real learning needs of adults.

While cosmopolitanism is far too general to equip workers in global work, the globalisation dominance view and the threats involved idealise old learning practices. Both the lack of tools and the tendency to idealise the past are obstacles to learning. Analysing the old activity and envisioning, modelling and re-tooling the new one are necessary conditions of learning in major transformations (Engeström, 1987). In the case of the coordinators of global work, this would mean analysing the ideal of co-located participation, looking to future-oriented alternatives to local supervision and face-to-face interaction, and creating tools for learning in and for distributed technology-mediated work. As I have demonstrated 
in this conclusion, it is fruitful to analyse learning theories not only in the context of educational activities but in all kinds of work contexts. Combined with an organisation-specific object history and actual-empirical data from a current activity, this approach enriches research on work-related learning, even for the use of practitioners. Different learning configurations are seldom fully articulated among workers and leaders, even though these configurations significantly contribute to the alternative developmental directions on the horizon.

\section{NOTES}

1 I interpret Sternberg et al.'s (1981) early piece of analysis to hint at the relevance of the theory history of psychological concepts in laypersons' accounts, but do not subscribe to the behaviourist orientation that the research theory-historically reflects.

2 This section is based on research reports on the case company. The references are not shown to maintain the anonymity of the company.

3 Literature on virtual communities of practice (VCoP) addresses the participation in online knowledge sharing and learning; see a review by Ardichvili (2008).

\section{REFERENCES}

Ardichvili, A. (2008). Learning and knowledge sharing in virtual communities of practice: Motivators, barriers, and enablers. Advances in Developing Human Resources, 10(4), 541-554.

Cairns, L., \& Malloch, M. (2011). Theories of work, place and learning: New directions. In M. Malloch, L. Cairns, K. Evans, \& B. N. O’Connor (Eds.), The Sage handbook of workplace learning (pp. 316). London: Sage Publications Ltd.

Chaiklin, S., Hedegaard, M., \& Juul Jensen, U. (Eds.). (1999). Activity theory and social practice: Cultural-historical approaches. Aarhus: Aarhus University Press.

Cole, M., \& Hatano, G. (2007). Cultural-historical activity theory: Integrating phylogeny, cultural history and ontogenesis in cultural psychology. In S. Kitayama, \& D. Cohen (Eds.), Handbook of cultural psychology (pp. 109-135). New York: The Guilford Press.

Collin, K. (2002). Development engineers' conceptions of learning at work. Studies in Continuing Education, 24(2), 133-152.

Engeström, Y. (1987). Learning by expanding: An activity-theoretical approach to developmental research. Helsinki: Orienta-konsultit.

Engeström, Y. (1999). Activity theory and individual and social transformation. In Y. Engeström, R. Miettinen, \& R. Punamäki (Eds.), Perspectives on activity theory (pp. 19-39). Cambridge: Cambridge University Press.

Engeström, Y. (2004). New forms of learning in co-configuration work. Journal of Workplace Learning, 16(1/2), 11-21.

Engeström, Y., Miettinen, R., \& Punamäki, R. (Eds.). (1999). Perspectives on activity theory. Cambridge: Cambridge University Press.

Engeström, Y., Pasanen, A., Toiviainen, H., \& Haavisto, V. (2005). Expansive learning as collaborative concept formation at work. In K. Yamazumi, Y. Engeström, \& H. Daniels (Eds.), New learning challenges: Going beyond the industrial age system of school and work (pp. 47-77). Osaka: Kansai University Press.

Fischer, G., \& Konomi, S. (2007). Innovative socio-technical environments in support of distributed intelligence and lifelong learning. Journal of Computer Assisted Learning, 23(4), 338-350.

Fuller, A., \& Unwin, L. (2005). Older and wiser? Workplace learning from the perspective of experienced employees. International Journal of Lifelong Education, 24(1), 21-39. 


\section{H. TOIVIAINEN}

Hakkarainen, K. (2009). A knowledge-practice perspective on technology-mediated learning. International Journal of Computer-Supported Collaborative Learning, 4(2), 213-231.

Koschmann, T. (1996). Paradigm shifts and instructional technology. In T. Koschmann (Ed.), CSCL: Theory and practice of an emerging paradigm (pp. 1-23). Mahwah, NJ: Lawrence Erlbaum.

Kunda, G. (2006). Engineering culture: Control and commitment in a high-tech corporation. Philadelphia, PA: Temple University Press.

Lam, W. S. E. (2006). Culture and learning in the context of globalization: Research directions. Review of Research in Education, 30, 213-237.

Lave, J., \& Wenger, E. (1991). Situated learning: Legitimate peripheral participation. Cambridge: Cambridge University Press.

Spring, J. (2008). Research on globalization and education. Review of Educational Research, 78(2), $330-363$.

Sternberg, R. J., Conway, B. E., Ketron, J. L., \& Bernstein, M. (1981). People's conceptions of intelligence. Journal of Personality and Social Psychology, 41(1), 37-55.

Toiviainen, H. (2015). Learning interventions at global workplaces. In T. Hansson (Ed.), Contemporary approaches to activity theory: Interdisciplinary perspectives on human behavior (pp. 214-227). Hershey: IGI Global.

Toiviainen, H., \& Engeström, Y. (2009). Expansive learning in and for work. In H. Daniels, H. Lauder, \& J. Porter (Eds.), Knowledge, values and education policy: A critical perspective (pp. 95-109). New York: Routledge.

Toiviainen, H., Lallimo, J., \& Hong, J. (2012). Emergent learning practices in globalizing work - The case of a Finnish-Chinese project in a Finnish technology consulting firm. Journal of Workplace Learning, 24(7/8), 509-527.

Victor, B., \& Boynton, A.C. (1998). Invented here: Maximizing your organization's internal growth and profitability. Boston, MA: Harvard Business School Press.

Vinck, D. (Ed.). (2003). Everyday engineering: An ethnography of design and innovation. Cambridge, MA: The MIT Press.

Wittel, A. (2000). Ethnography on the move: From field to net to Internet. Forum Qualitative Social Research FQS, 1(1), Art. 21.

\section{Hanna Toiviainen}

Center for Research on Activity, Development and Learning (CRADLE)

Institute of Behavioural Sciences, University of Helsinki, Finland 
SISSEL KONDRUP

\title{
3. WORK AND LEARNER IDENTITY
}

\author{
Developing an Analytical Framework
}

\section{INTRODUCTION}

The aim of this chapter is to suggest a theoretical framework able to assess how people's engagement in specific historical and social work practices is significant to their development, maintenance or transformation of a learner identity. Such a framework is crucial in order to grasp how different groups have distinctive conditions for forming a proactive learner identity and engage in lifelong learning, and thus for meeting the obligations prevalent in both national a transnational policies on lifelong learning.

This chapter outlines how Archer's Critical Realist approach and concepts of personal identity, natural, practical and social concerns (Archer, 2000, 2003) and Salling-Olesen's Life-historical approach rooted in Critical Theory $(2002,2007)$ can conceptualise the relation between work and identity. It is suggested how they can contribute to a theoretical framework, enabling researchers to examine how learner identities are formed through peoples' on-going engagement in specific work lives.

The framework was originally developed as part of an empirical study aiming to understand how people working unskilled jobs perceive the meaning of adult education and training and how their perceptions were conditioned by their work life experiences. The study arose from a curiosity of why workers in unskilled jobs - most likely to be marginalised as a result of the decreasing demand for unskilled labour - are least likely to participate in adult education and training (Desjardins et al., 2006) and tend to be reluctant towards the educational optimism driving educational policies (Paldanius, 2002).

\section{LIFELONG LEARNING AND THE REQUEST FOR PROACTIVE LEARNER IDENTITIES}

Lifelong learning and training has for decades been proclaimed as the prerequisite for both societal and individual prosperity and welfare. The need for lifelong learning is substantiated by developments in the globalised economy, intensified international competition and the transformation from industrial to knowledgebased economies, technological changes and new forms of organisations, all of which has increased the demand for qualified labour (Bélanger \& Tuijnman, 1997; Desjardins, 2009). 


\section{S. KONDRUP}

The political awareness of the economic importance of adult education has intensified concurrently with the growth of neo-liberalism from the early 1980s (Desjardins, 2009). The prevalence of neo-liberal economic theory manifest in politics representing the so called Washington Consensus has diminished the possibility to apply traditional macro-economic tools and regulate the national demand for labour and thus substantially reduced the capacity of national governments to protect their citizens against the social and material risk from unemployment (Desjardins, 2009). Instead the endeavour to strengthen workforce employability has become the means to ensure both individual and societal welfare.

The increased emphasis on adult education and lifelong learning can thus be seen as an attempt to protect the citizens by providing the opportunity to obtain and maintain employability (Brown et al., 2002). This is reflected in current transnational and national lifelong learning policies. They define lifelong learning as a means to increase workforce employability. They further build on the assumption that the evolving labour market increases the demand for highly qualified labour and that knowledge and skills become obsolete faster, and, therefore, employability must be ensured through continuing up- and re-skilling.

Furthermore the dissemination of quality standards implies an increased demand for certifications. This suggests that if knowledge and skill are to be treated as capital in the labour market, they need to be documented and formalised. Therefore everyone is obliged to some degree to engage in formal learning activities in order to obtain certificates documenting their qualifications (Kondrup, 2012).

The perception that lifelong learning, through formal re- and up-skilling, is necessary for developing a competitive economy and ensuring societal welfare and prosperity implies that people not participating are a dual risk. They risk being marginalised in a labour market with increased demand for formal qualifications and they become a societal liability for the development of a competitive economy (Brine, 2006).

The subjects of lifelong learning policies are no longer certain groups, instead everyone is defined as an educable subject, and not just an educable subject but a self-governing educable subject, who shall desire to participate in lifelong learning (Fejes, 2006) and thus is obligated to formulate a proactive learner identity (Kondrup, 2012). This implies that participation moves from being a right to becoming a duty (Biesta, 2006).

\section{DIFFERENT PARTICIPATION PATTERNS AND DIFFERENT ORIENTATIONS TOWARDS PARTICIPATION}

Even though lifelong learning policies define everybody as educable subjects emphasising the need for everyone to engage in lifelong learning, transnational surveys examining the distribution of adult education reveal significant inequalities between distinct groups.

The opportunity for participation in adult education and training are determined by 'the long arms of' the family, the job and the welfare state (Desjardins et al., 
2006). The distribution of adult education and training is characterised by a Matthew effect: those who already possess a high degree of formal qualifications are most likely to participate. The same tendency is prevalent for the opportunity of informal and non-formal learning at the workplace (Desjardins et al., 2006). So even though people working unskilled jobs are most at risk of being marginalised by changing demand for labour, they are least likely to participate in adult education and training.

International surveys also reveal that people working unskilled and low skilled jobs have low expectations as to the benefits adult education and training offer, and generally are less motivated than other groups.

This pattern, that low and unskilled workers seem reluctant towards adult education and training, has drawn attention to the attitudes of this target group to adult education.

Researchers examining participation and non-participation from the perspective of different target groups argue that orientations toward adult education and training must be understood as elements in specific life histories or biographies, where certain habitual dispositions (Paldanius, 2002; Hodkinson \& Hodkinson, 2004), cultures (Klindt \& Sørensen, 2010), significant learning activities (Antikainen, 2006) and changing value contexts (Lynch, 2008) affect how people perceive adult education and training.

But even though there is a correlation between people's jobs and their orientation towards adult education and training, research examining the meaning of adult education from the perspective of the target groups tends to overlook how this is situated in a specific work-life history. They thus tend to overlook how people's engagement in specific work practices affects how they perceive their need and opportunity to participate in different kinds of learning activities and engage in lifelong learning. This raises the risk of overlooking how the specific content and organisation of work, jobs and tasks contribute to the reproduction of certain dispositions or cultures (Kondrup, 2013).

\section{LIFELONG LEARNING AND LEARNER INDENTITY}

The claim that everybody has to maintain employability by participating in lifelong learning makes it crucial to understand how different kinds of work forms distinguish conditions for meeting the obligation of positioning oneself as an educable subject and engaging in lifelong learning. One way of doing this is to examine how people's engagement in specific work lives conditions their learner identities.

The inspiration to apply the concept learner identity comes from Antikainen (2006). He uses the concept to examine the changing meaning of education and learning in Finland in the post-World-War II era. Antikainen borrows the concept from Weil, who defines learner identity as the value and belief ascribed to different kinds of learning activities and their outcome: 
Learner identity suggests the emergence or affirmation of values and beliefs about 'learning,' 'schooling' and 'knowledge.' (Weil, quoted in Antikainen, 2005, p. 7)

Antikainen examines how learner identities are formed by significant learning experiences and significant others during one's life course.

Even though Antikainen emphasises that significant learning experiences occur at work and that co-workers and employers often play the role of significant others, he does not explicitly address the specific work of his informants and thus tends to overlook how the content and organisation of workplaces give rise to certain learning experiences. His theoretical foundation in symbolic interactionism also implies a primary focus on how social relations hinder the attention to the practical and physical engagement in the workplace.

Interviews with people working unskilled jobs, conducted as a part of the study mentioned earlier, revealed that their perception of both need and opportunity to participate in adult education and training and other kinds of learning activities was conditioned by their work-life experiences. For them, the meaning of adult education and training was, for example, conditioned by their experiences of (changing) opportunities to apply different kinds of knowledge and skills in their job. It also revealed that the physical nature of their job generated concern for their capacity to continue working and played a role in their perception of need and opportunity vis-à-vis participation in learning activities.

In order to mitigate this complexity I found it necessary to reframe the concept of learner identity to accentuate the relation between work and identity.

\section{WORK AND LEARNER IDENTITY}

Research on workplace learning reveals that workplaces form the context for substantial practical involvement and social interactions facilitating learning processes.

Through learning at work people accomplish significant work capacities as well as general capacities and they acquire knowledge of the world and themselves. Studies of workplace learning also reveal that jobs establish certain learning trajectories (Lave \& Wenger, 2001) and learning affordances (Billett, 2006), forming specific conditions for the identity process (Archer, 2000; Salling Olesen \& Weber, 2001).

Therefore engagement in work has to be emphasised when examining how people develop, maintain or transform their learner identity: not work as an abstraction but as historical, social and material practices where people engage in jobs and tasks with specific content and organisation that condition their performance and their learning and identity processes.

In order to develop a framework to ascertain how learner identities are formed through peoples' engagement in work I will present two different perspectives explicitly addressing the relation between work and identity, both defining the identity process as dialectical and on-going throughout life. They are Archer's 
(2000, 2003) critical realistic approach and Salling Olesen's life-historical approach rooted in critical theory (Salling-Olesen, 2002, 2007).

\section{IDENTITY AND CONCERN}

Archer's critical realist approach emphasises peoples' concerns as constitutive for the identity process. She asserts the notion of common humanity and defines human beings as the ultimate origin of social life and socio-cultural structures. But she also emphasises that humans are always born into societies comprising specific cultures and structures with temporal priority, relative autonomy and casual efficacy to the members of society.

She opposes the notion of free rational agents central in modernist social science, arguing that both rationality and possible actions are conditioned by social structures. She also rejects the post-structural reduction of humans to society's being, which displaces the human subject in favour of social structures (Archer, 2003).

The perception of the practical origin of human consciousness is what distinguishes the social realistic concept of persons from the modernist "free rational agents" and post-structural "society's beings":

Instead of rehabilitating Enlightenment Man with his incorporeal consciousness, or any equally mentalistic portrayals of humanity, social realism makes our real embodied selves living in the real world really loadbearing. It constitutes a naturalistic account of consciousness rather than taking the latter as an aprioristic endowment. Nevertheless, contra postmodernism, this is an account of consciousness with a real history which, in turn, ultimately accounts for there being a real world history. (Archer, 2000, p. 22)

According to Archer human beings possess certain emergent properties (self-hood, consciousness, identity, reflexivity and agentic action) whose realisation comes about through necessary relations between embodied practice and the environment. The social world contains cultures with cultural emergent properties (language, theories, values and believes) and structures with structural emergent properties (distributions, roles, organisations and institutions).

The concept of emergent properties posits that their development is relational, but that they obtain their own irreducible powers subsequently affecting the relation. One example is, that both structures and cultures are produced and reproduced by human agency but develop their own emergent properties (e.g. institutions and values) conditioning human agency. Likewise by acquiring language and theories people develop their ability to abstractly think and to formulate alternatives to their current situation, thus altering their behaviour and the social structures. This implies that people, structures and cultures must be perceived as interrelated but irreducible and ontologically different.

Referencing Bhaskhar Archer argues that people develop their identity as a part of their on-going engagement in the three orders of reality: the natural, the 


\section{S. KONDRUP}

practical, and the social order. The differentiated reality entails that engagement gives rise to natural (bodily), practical (performative), and social emotions and concerns. The human embodiment confers concerns about physical well-being. Performative concerns are a consequence of our engagement in practical activities:

Performative concerns are unavoidably part of our inevitable practical engagement with the world of material culture. The precise objects of performative concerns are historically, cross-culturally and socially varied, but the import of our competence in dealing with the practical realm is universal. (Archer, 2000, p. 198)

Social concerns are linked to the social judgement of approval or disapproval, and the most important social concern is the self-worth vested in different projects.

It is because we have invested ourselves in these social projects that we are susceptible to emotionality in relation to society's normative evaluation of our performance in those roles. Our behaviour is regulated by hopes and fears that is anticipations of social approbation/disapprobation. (Archer, 2003, p. 16)

The presence of simultaneously diverse and potentially conflicting concerns forces people to form a modus vivendi and prioritise their ultimate concerns. The personal way of prioritising these concerns is what gives people their personal identity (Archer, 2000, p. 221). The establishment of a durable modus vivendi is an achievement and it can be destabilised by changes in the circumstances and transitions in the life course (e.g., losing employment, having an accident or going through a divorce).

The situations in which people find themselves and develop their modus vivendi are not of their own making. Humans are born into a socially structured and stratified society, where different groups have distinct possibilities and find themselves in different situations giving rise to certain concerns. Therefore different groups have different conditions for forming a modus vivendi and personal identities.

In order to understand the relation between work and learner identity Archer's approach emphasises that personal identity is continuously reproduced by people always engaged in a differentiated reality. This engagement is always at the same time bodily, performative and social. Therefore engagement in work must be analysed as engagement in physical, practical as well as social practices causing different concerns.

In order to understand how engagement in work conditions people's learner identity - their orientation towards adult education and training - it is necessary to apply an approach sensitive to how people's engagement at work gives rise to specific bodily, performative and social concerns, and how it influences their perception of their opportunities to comply with these concerns; especially how and to what extend they perceive participation in different kinds of learning activities as compatible with their concerns. 


\section{EXPERIENCE AND IDENTITY}

Salling Olesen's life historical approach to adult learning emphasises experience as constitutive for the identity process. His ambition is to develop a theoretical framework that accounts for the significance of both the social context addressed by theories of work-related learning and the individual learning processes and learning potentials addressed by psychological and cognitive approaches to learning. The framework thus addresses both subjective and societal conditions for learning (Salling Olesen, 2007).

The framework is inspired by concepts developed in research on work, socialisation and adult learning rooted in Critical Theory (the Frankfurt school), especially Lorenzer's Materialistic Theory of Socialisation, Negt's concept of Experience, and Leithäuser's concept of Everyday Consciousness. The ambition within this tradition of critical theory is to maintain the notion of work as a key category when studying socialisation, learning and subjectivity and to examine how changes in societal work affect the conditions for the continuing production of subjectivity.

The production and reproduction of subjectivity are defined as the ongoing result of psycho-societal learning processes:

We take our concept of the subject from the tradition of critical theory (the Frankfurt School). As opposed to liberal thinking (which holds a hegemonic position, including in most social science) the critical theory focuses on the production of human subjectivity through socialisation, in which a specific version of cultural and social experience is embodied, becoming a complex of conscious and unconscious predictions for subjective action and later experience. Avoiding the dichotomy of liberal theory between the free subject and a social, constraining environment we assume on the contrary that subjectivity is something that must continuously be learned socially. (Salling Olesen, 2002, p. 15)

The crux from Lorenzer's materialistic socialisation theory is that subjectivity is perceived as a result of socialisation processes. According to Lorenzer human consciousness develops in a dialectic process between the child and its immediate environment. Through this process the child acquires and internalises a certain version of cultural knowledge (e.g., language, concepts, beliefs, techniques, values and norms) constitutive for how she perceives and interprets herself and her environment. Both the immediate environment and the specific version of the cultural knowledge the child acquires are embedded in and structured by broader societal structures, hence consciousness and subjectivity are societal.

The life historical approach argues, that the socialisation process continues throughout life. Consequently the formation of subjectivity cannot be reduced to the early life phases and the identity process must be perceived as an ongoing life historical process. 


\section{S. KONDRUP}

The concept of experience in the definition above is borrowed from Negt. According to Negt experience is not representation but an active process with three modalities, relatively independent but mediated through each other: immediate experience, life (historical) experience, and objectified experience (cultural knowledge) (Salling-Olesen, 2007). Peoples' lives unfold in specific social and historical situations giving rise to certain immediate experiences. The experience process is also embedded in a specific life history and conditioned by previous experiences and the specific version of internalised cultural knowledge internalised through socialisation.

Immediate experiences, life historical experiences and objectified experiences are social and embedded in a specific history. Therefore they cannot be understood or interpreted without attention to the broader societal circumstances. In other words, peoples' learning strategies in relation to their work-life are constituted by their specific situation, previous experience and cultural knowledge. They are embedded in a specific labour market, with certain historical and social structures (e.g., division of labour amongst professions and gender) and different traditions for training (e.g., schooling or apprenticeship) and specific technological and organisational trends and changes. They are also embedded in a specific life history with certain school experiences, skills and knowledge, experience of being able to apply different kinds of skills in the job, desires, dreams and fears. Finally they are constituted by specific objectified experience/ cultural knowledge (e.g., work ethics, gender roles, professional hierarchies and values and ideas, such as collective vs. private ownership and competition vs. collaboration).

According to the life historical approach, the identity processes must be perceived as ongoing experience processes through which the subjects develop their capacities and their perception of themselves vis-à-vis the world:

Every individual has specific emotional and social experiences which have sedimented a general view of the world and ways of seeing him/herself. [...] We may therefore understand identity processes in terms of this sedimentation and ongoing engagement in the world. Identity is thereby not seen as a final and stable self-definition, but as a partly fluent, partly contradictory, and always active engagement and (re)construction of oneself. (Salling Olesen, 2007, p. 13)

By conceptualising identity as the result of an ongoing dialectic experience process it is stressed that identity is neither static nor essential. Identity is the result of a particular subject's continuous engagement in social and historical practices in specific situations giving rise to immediate experiences. By emphasising the life historical development of consciousness and identity it is stressed that identities are not arbitrary and individual but psycho-societal, formed by specific life historical experiences enabled by the engagement in specific social and historical situations.

Another ambition of the life historical approach is to understand how changes in societal work change the condition for the establishment of subjectivity. This continues a Marxist tradition aiming to understand the relation between capitalism, changing work conditions and identity. Salling Olesen draws on the work of 
Leithäuser and Becker-Schmidt. Especially their research about the generalisation of labour - the tendency that more and more aspects of human life (production and reproduction) become subject to market relations - reveals that peoples' life context becomes fragmented and contradictory with severe consequences for their identity process.

According to Leithäuser (1993) people develop everyday consciousness as a psychological defence, reducing anxiety and conflicts by suppressing or displacing societal conflicts. Becker-Schmidt (1983) stresses that societal conflicts and ambiguities are internalised and cause ambivalence. The fragmentation of life contexts in capitalist societies thus implies that peoples' identity can be ambiguously conditioned by unconscious and suppressed societal conflicts.

In order to understand the relation between work and learner identity the life historical approach emphasises that the learner identity is formed, maintained or transformed in an on-going experience process, conscious as well as unconscious, where both individual life experiences, immediate experiences and objectified experiences are significant for how the subjects perceive them self, their situation and their possible actions.

The life historical approach also emphasises that the identity processes are not necessarily harmonious since societal contradictions and conflicts are asserted on the subjective level as ambivalences and repressions, and that learner identities therefore can be ambiguous. Therefore peoples' learner identity - their orientation towards adult education and training - must be examined as elements in specific work-life stories.

\section{COMBINING THE PERSPECTIVES: TOWARDS A DIALECTICAL CONCEPT OF LEARNER IDENTITY}

Archer's critical realism and Salling Olesen's life historical approach share a claim of humanism, and the ambition of bringing the subject to the forefront of social science. They also both insist on the dialectical nature of identity process, emphasising the constitutive power of the historical, social, and material context. But there are also substantial differences (see Kondrup, 2012). This paper does not provide an adequate discussion of these differences. Instead I will suggest how concepts from the two perspectives can be combined to contribute to a conceptualisation of learner identity.

The life historical approaches enable us to understand how identity is continuously formed, maintained or transformed in experience processes mediated by certain immediate (potentially ambiguous) experiences generated by peoples' continuous engagement in specific historical and social practices, their life historical experiences and their cultural knowledge.

People's learner identity, defined as their perceived needs and opportunity to engage in different learning activities, must therefore be analysed as the result of specific experience processes with three modalities, relatively independent but mediated through each other: immediate experience, life (historical) experience and objectified experience (cultural knowledge). 


\section{S. KONDRUP}

Archer's concepts of a fragmented reality and bodily, performative and social concerns emphasise another complexity in the experience process. The engagement in immediate situations always affords both bodily, performative and social concerns and emotions influencing the experience processes and therefore (potentially) the learner identity.

The assumption that learner identities are the result of ongoing experience processes fuelled by peoples' engagement in differentiated and fragmented practises can be illustrated as in Figure 1.

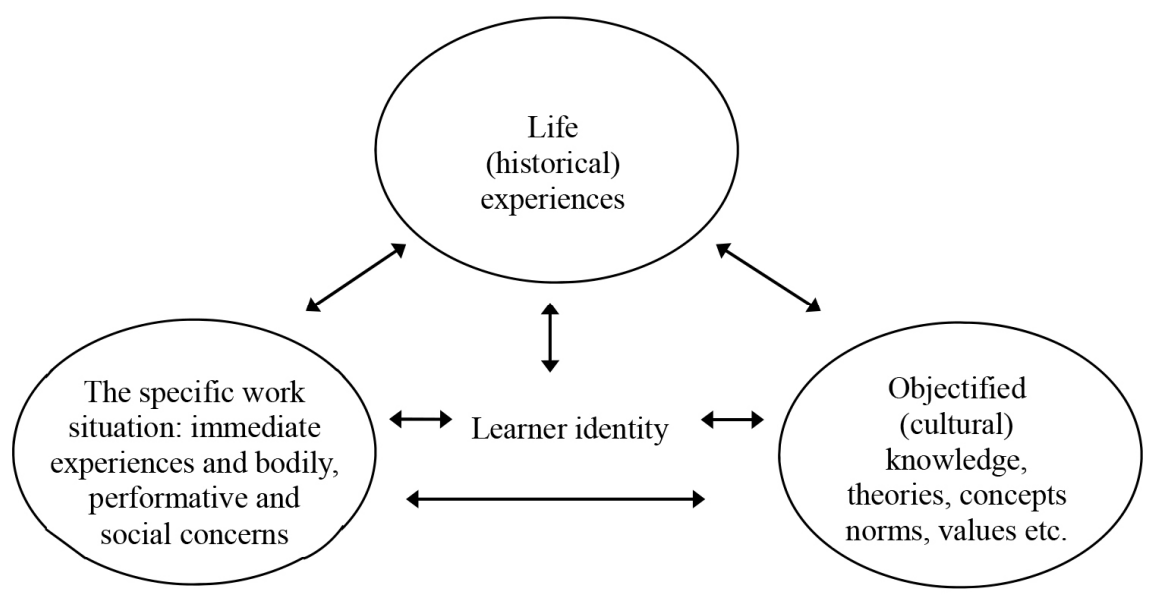

Figure 1. Learner identity (Kondrup, 2012)

Reducing engagement in work to either social (e.g. relational) or cognitive (e.g. rational) involvement - a tendency prevalent in research on unskilled and low skilled workers - tends to overlook that engagement in work is always also bodily and practical and that the practical and the bodily engagement in work give rise to certain concerns and emotions. For example, concerns of degeneration or coping, concerns for the quality of the product and concerns for feeling competent and being in control of the job (Kondrup, 2012).

Consideration of the differentiated nature of human engagement illustrates that the content and organisation of work plays a significant role when people form, maintain and transform their learner identity. The content and organisation of the job (e.g., task variations, physical strain and risk of degeneration, work procedures, speed and noise, degree of opportunities for creative problem solving, degree of autonomy, career patters, training and recruitment programs, etc.) condition how people perceive their need and opportunity to engage in different kinds of learning activities in relation to their work situation.

In order to understand how distinct learner identities are formed, maintained or transformed through engagement in different kinds of work, it is therefore crucial to examine how engagement in different kinds of work gives rise to certain 
concerns and different opportunities to comply with these concerns. And it is important to examine how and to what extend people perceive participation in different kinds of learning activities, including adult education and training, as means to comply with their concerns.

\section{CONCLUSION}

Within the research on participation in adult education and training, there has been a tendency to overlook how and why engagement in specific work practises conditions how people perceive the meaning of adult education and training. This has left a crucial question unanswered: how do different kinds of work provide diverse conditions for people to meet the obligation of forming a proactive learner identity in order to engage in lifelong learning? Turning to Archer's critical realism and Salling Olesen's life historical approach we can get a framework that focuses on how engagement in specific social, historical and material practises - including work - are constitutive for the identity process.

The application of the dialectic concept of learner identity outlined above can enable researchers within the field of adult education and training to examine how peoples' perception of their needs and opportunities to participate in job related adult education and training are formed by their specific life historical experiences and by the bodily, performative and social concerns they have in relation to their current and future work life.

An approach focusing on peoples' work life experiences and concerns can thus reveal how their work life forms certain conditions for them to develop, maintain or transform a proactive learner identity and position themselves as educable subjects. By insisting on Salling Olesen's concept of fragmented life situation and Archer's concept of differentiated reality the resulting framework enables concise assessment of the continuous evolution of a learning identity, in addition to exposing the potential conflicts and ambiguities that illustrate how learner identities can be both provisional and ambiguous.

\section{REFERENCES}

Antikainen, A. (2005). In search for the meaning of education and learning. In A. Antikainen (Ed.), Transforming a learning society - The case of Finland (pp. 273-296). Bern: Peter Lang.

Antikainen, A. (2006). Participation in adult education in a Nordic context. In A. Antikainen, P. Harinen, \& C. A. Torres (Eds.), In from the margins - Adult education, work and civil society (pp. 131-147). Rotterdam: Sense Publishers.

Archer, M. (2000). Being human: The problem of agency. Cambridge: Cambridge University Press.

Archer, M. (2003). Structure, agency and the internal conversation. Cambridge: Cambridge University Press.

Becker-Schmidt, R. (1982). Modsætningsfyldt realitet og ambivalens. Udkast: dansk tidsskrift for kritisk samfundsvidenskab, 10(2).

Bélanger, P., \& Tuijnman, A. (1997). New patterns of adult learning: A six-country comparative study. Oxford: Pergamon Press and UNESCO Institute for Education. 


\section{S. KONDRUP}

Biesta, G. (2006). What's the point in lifelong learning if lifelong learning has no point? On the Democratic Deficit of Policies for Lifelong Learning. European Educational Research Journal, 5(3/4), 160-180.

Billett, S. (2006). Work, subjectivity and learning. In S. Billett, T. Fenwick, \& M. Somerville (Eds.), Work subjectivity and learning - Understanding learning through working life (pp. 1-20). Dordrecht: Springer.

Brine, J. (2006). Lifelong learning and the knowledge economy: Those that know and those that do not: The discourse of the European Union author(s). British Educational Research Journal, 32(5), 649665.

Brown, P., Hesketh, A., \& Williams, S. (2002). Employability in a knowledge-driven economy. Working Paper 26, School of Social Science, Cardiff University.

Desjardins, R. (2009). The rise of education as an economic policy tool: Some implications for education policy research. In R. Desjardins \& K. Rubenson (Eds.), Research of vs. research for education policy - In an era of transnational policy-making (pp. 18-41). Saarbrücken: Verlag Dr. Müller.

Desjardins, R., Rubenson, K., \& Milana, M. (2006). Unequal chances to participate in adult learning: international perspectives. Fundamentals of Educational Planning 83. UNESCO: International Institute for Educational Planning, Paris.

Fejes, A. (2006). Constructing the adult learner - A govern mentality analysis. Doctoral Thesis. Studies in Education and Psychology No. 106. Linköping: Linkøping Universitet.

Hodkinson, P., \& Hodkinson, H. (2004). The significance of individuals' dispositions in workplace learning: A case study of two teachers. Journal of Education and Work, 17(2), 167-182.

Klindt, M. P., \& Sørensen, J. H. (2010). Barrierer og løftestcenger for kortuddannedes opkvalificering. Copenhagen: Nationalt Center for Kompetenceudvikling. http://vbn.aau.dk/files/41338633/NCK kortuddannedes_opkvalificering_Klindt_og_S_rensen.pdf

Kondrup, S. (2012). Livslang laering for alle - en arbejdslivshistorisk undersøgelse af det ufagloerte arbejdsliv som betingelse for livslang laering. Doctoral Thesis. Roskilde: Forskerskolen for Livslang Læring. Roskilde Universitet.

Kondrup, S. (2013). Researching participation in adult education - Looking back and moving forward. Unpublished paper presented at ESREA Network Conference, Access, Learning Careers and Identities, Linköping, November 2013.

Lave, J., \& Wenger E. (1991). Situated learning: Legitimate peripheral participation. Cambridge: Cambridge University Press.

Leithäuser, T. (1993). Teorien om hverdagsbevidsthed i dag. Tekster til voksenpaedagogisk teoriudvikling. Roskilde: Roskilde Universitet.

Livingstone, D. W. (2003). Hidden dimensions of work and learning: The significance of unpaid work and informal learning in global capitalism. Journal of Workplace Learning, 15(7/8), 359-367.

Lynch, H. (2008). Lifelong learning, policy and desire. British Journal of Sociology and Education, 29(6), 677-689.

Paldanius, S. (2002). Ointressets rationalitet - om svårigheter att rekrytera arbetslösa till vuxenstudier. Doctoral Thesis. Linköping Studies in Education and Psychology No. 86. Linköping: Linköping Universitet.

Salling Olesen, H. (2002). Experience, language and subjectivity in life history approaches - Biography research as a bridge between the humanities and the social sciences. Paper No. 14, Life History Project, Roskilde University.

Salling Olesen, H. (2006). Learning and experience. In S. Billett, T. Fenwick, \& M. Somerville (Eds.), Work subjectivity and learning - Understanding learning through working life (pp. 53-67). Dordrecht: Springer.

Salling Olesen, H. (2007). Theorising learning in life history: A psychosocietal approach. Studies in the Education of Adults, 39(1), 28-53. 
Salling Olesen, H., \& Weber, K. (2001). Space for experience and learning: Theorizing the subjective side of work. In K. Weber (Ed.), Experience and discourse - Theorizing professions and subjectivity. Roskilde: Roskilde Universitetsforlag.

\section{Sissel Kondrup}

Department of Psychology and Educational Studies

Roskilde University, Denmark 



\title{
4. KEY PREDICTORS OF LEARNING TRANSFER IN CONTINUING VOCATIONAL TRAINING
}

\author{
Development of a Theoretical Framework and Testing of an Empirical \\ Model with Structure Equation Modelling (SEM)
}

\section{INTRODUCTION}

'Training off the job' always features an element of uncertainty. For example, is there a transfer of knowledge from the training place to the workplace? If there is such a transfer, which effects and potential side effects appear? If there are effects, how sustainable are these initiated changes? Monitoring the learning transfer of continuing vocational training is therefore crucial in order to control the training success and to legitimate the investments made. It is not surprising that the design of training measures is currently leading the list of challenges within vocational training (SCIL trend study, Diesner \& Seufert, 2010).

The two questions - i.e. 'What effects are noticed in the work context?' (outcome-oriented research; Kirkpatrick \& Kirkpatrick, 2006; Philipps \& Philipps, 2010) and 'Which parameters contribute to knowledge development and knowledge transfer?' (process-oriented research; Holton, 2000; Bates et al., 2007) - are discussed in separate lines of research. Practice and research of continuing vocational training are currently dominated by these two approaches. However, a linked study of process and outcome data is a necessary condition in order to evaluate and improve the effect of training in the work context (Desky \& Tessaring, 2006). According to Baldwin and Ford (1988), learning transfer is defined as follows: 'For transfer to have occurred, learned behavior must be generalised to the job context and maintained over a period of time on the job' (ibid., p. 63). In this respect, we argue that the movement from learning to application does not imply that knowledge from the learning field may easily be transferred to the workplace (the performance field). A more suitable term or concept would be 'transformation,' because learning transfer in vocational training is more like a context-based transformation of knowledge. If both contexts - the learning field and the performance field - have an effect at the same time, transfer takes place in parallel, not sequentially. On one hand, transfer occurs as transformation within the learning and the performance fields, and on the other hand, these transformations build resources for the respective other field. In this 
understanding, the learning field exists 'beside' the performance field, not after it, and the effects are mutually reciprocal, not unilateral.

Firstly, we argue for a research approach which combines the two separated approaches - process-oriented research and outcome-oriented research - with regard to successful learning transfer. Secondly, we develop an adequate theoretical framework model on the basic assumption of 'transfer as transformation.' Thirdly, we tested our model empirically by using structural equation modelling (SEM). In this way we are able to identify linked key predictors of learning transfer in continuing vocational education and training.

\section{PROBLEM SPECIFICATION}

In the following, outcome-oriented, process-oriented and integrated research approaches are introduced according to their chronological emergence.

\section{Outcome-oriented Research Approaches}

In 1959 and 1960, Donald Kirkpatrick published the 'Four Level Evaluation Model' in a series of four short articles, which largely remained unchanged (Kirkpatrick \& Kirkpatrick, 2006). The model describes four outcome levels of incompany training in an ascending hierarchy:

Level 1: Reactions (participants' satisfaction)

Level 2: Learning (participants' learning outcomes)

Level 3: Behaviour (transfer outcomes)

Level 4: Results (business outcomes)

However, outcome-oriented approaches may not reveal how the outcomes emerge, how they can be affected and how they can be systematically enabled in the training. Moreover, the outcome-oriented approach may foster incorrect interpretations: inasmuch as the transfer fails, it is possible that, for example, bad training is the reason for inadequate learning. However, other process factors (e.g. a missed opportunity to apply what is learned at the workplace) may also be further reasons which are not taken into account in these models.

The focus of our study is located on Kirkpatrick's level 3: 'Behaviour.'

\section{Process-oriented Research Approaches}

By the end of the 1980s, process-oriented research approaches were developed as a counter-draft to the outcome-based paradigm, 'moving beyond the question of whether training works to why training works' (Holton et al., 2000, p. 337; italics in original). These entail (self-)critical assessment and analysis of implementation practice and thus enable the improvement of program planning and control. The systematic starting point represents Baldwin and Ford's essay 'Transfer of training: A review and directions for future research' (1988). In their article, based on an 
intensive literature review, Baldwin and Ford develop a heuristic model of transferaffected process factors which they divide into the following three groups: factors of the learners, the training and the workplace. Figure 1 presents Baldwin and Ford's basic model (1988, p. 65).

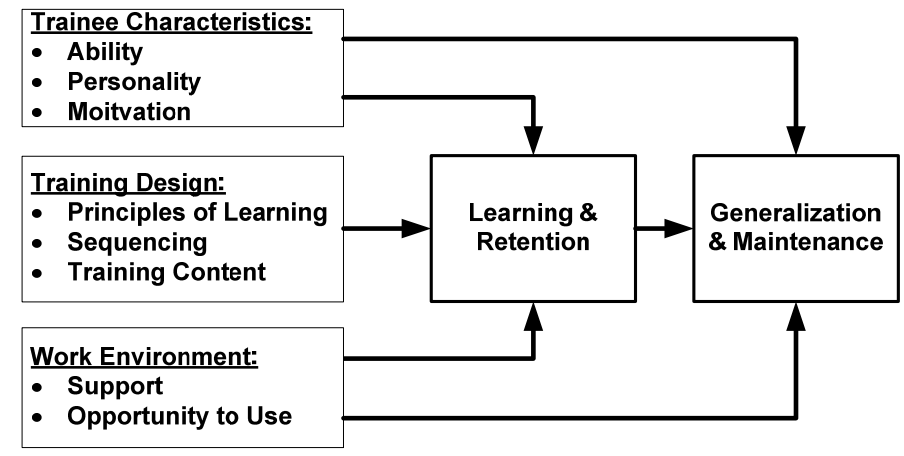

Figure 1. Factors and linkages

Baldwin and Ford's heuristic model aims at identifying and grouping the transfer-promoting factors. Both authors considered the connections and structuring of the factors: 'It has been stated that we must take into account a variety of factors and linkages that, to date, have not been adequately examined' (Baldwin \& Ford, 1988, p. 98). Although the testing of these factors and the identification of further factors have been intensively carried out, the structure or connection of factors ('linkages') has been neglected. This is why Cheng and Ho (2001), in their meta-analysis of studies on learning transfer conducted from 1989 until 1998, recommended future testing of structures as well as examination using SEM.

A central actor was and remains Elwood F. Holton, who integrated various model approaches as well as individual findings in a comprehensive model, the 'HRD Evaluation Research and Measurement Model' (Holton, 1996, 2005). On that basis, Holton and colleagues then developed the 'Learning Transfer System Inventory (LTSI).' The aim is that the LTSI covers all factors (individual, training and organisation) which influence the transfer (Holton et al., 2000). The comprehensive LTSI covers 16 factors using the self-assessment of the participants. These factors are grouped into four categories (secondary influences, motivation, environment, ability) and subdivided into two construct domains (11 training-specific factors that influence the transfer independently and five general factors that influence the transfer independently from the concrete training).

Figure 2 presents the factors of the 'Learning Transfer System Inventory' (based on Holton, 2005, p. 48). 


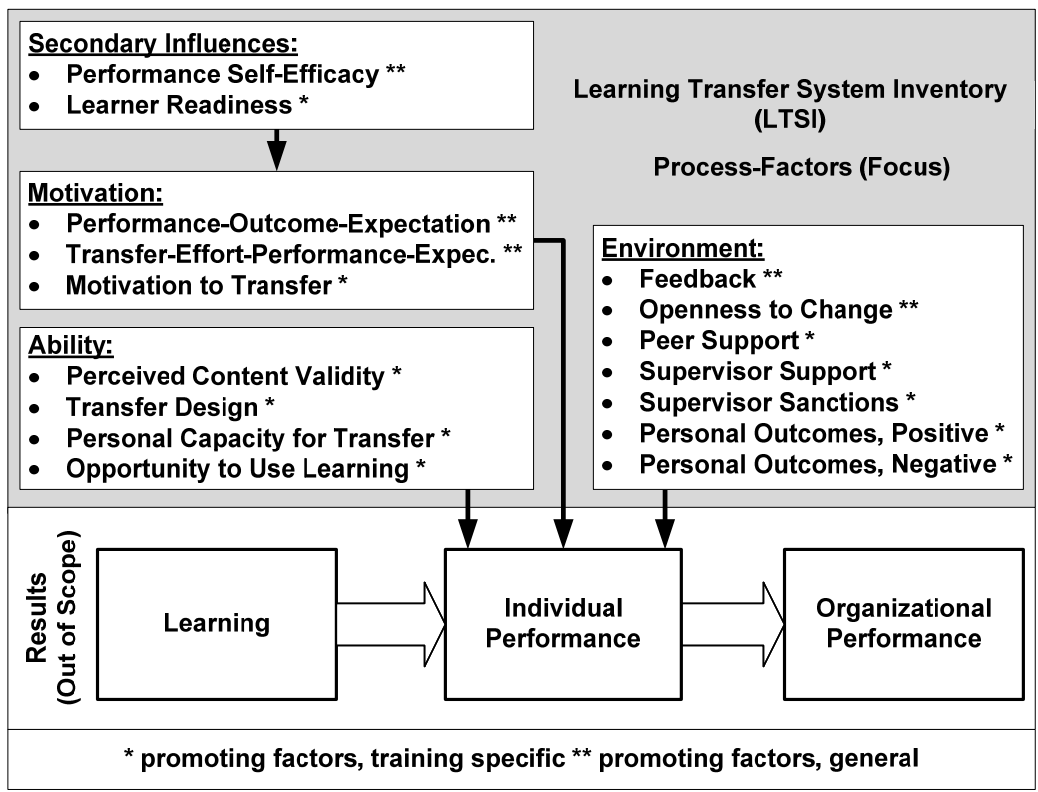

Figure 2. Factors of the 'Learning Transfer System Inventory'

A basic assumption of this approach is that the individual learning transfer of a system is dependent on various process factors. A further basic assumption is that the learning transfer is a sequential process with the following sequences: (1) learning, (2) individual performance and (3) organisational performance. A third, more hidden basic assumption is provocatively formulated: When the processes are explained, then the outcomes are peripheral. Although the processes are directed towards the outcome dimension, the outcomes themselves are not the subject of the instrument but are instead 'out of scope' (see Figure 2). The approach includes the possibility to consider the outcomes in order to quantify the impact of linkages and to evaluate the effect of the various process factors (Kauffeld, 2010).

The processes build the goal of such process-oriented research approaches, whereas the outcomes are only a medium for the identification of valid factors. Ignoring this limitation, this line of research is highly accepted (Blume et al., 2010).

\section{Integrated Research Approaches}

On the one hand, integrated research approaches (linking process and outcome data) exist in research areas outside of our focus, i.e. in-company training. Their roots can also be traced back to the 1960s. Some of the key protagonists in this field (among others in medicine, care, children and youth aid as well as education) 
include Avedis Donabedian (1966), with his discussion of the conceptualisation of evaluation which includes the three dimensions of structure, process and outcome, as well as Daniel L. Stufflebeam (1972), with his 'Context-Input-Process-ProductModel' (CIPP-Model). On the other hand, integrated approaches also exist in incompany training research and in integrated single studies (for example, Noe \& Schmitt, 1986; Mathieu et al., 1992; Bates et al., 2007), which also take into account process and outcome data. However, while this integrated research approaches do not create an independent line of research line, they present important resources for the study presented in this chapter.

\section{Problem Specification and Focus of Our Research}

The initial situation of our investigation can be summarised as follows: The outcome-oriented research approach particularly serves the legitimation of the training investments. The question of how to design trainings cannot be answered with this approach (the processes are 'out of scope'). The process-oriented research approach serves in contrast with the reflection and improvement of the implementation practice and the design principles, but it does not assess the training outcome (the outcome is 'out of scope'). Resulting effects (success control) and the legitimacy of training investments are not intended by processoriented research approaches.

A shortage in the outcome constructs or process factors does not exist (see Figures 1 and 2). Nevertheless, the quality of transfer research does not improve itself when the research just follows the 'all-principles' of 'all outcomes,' 'all factors.' It is more necessary to link outcome and process data structurally in order to equally answer the questions on control/legitimacy and reflection/development.

Integrative approaches, which do not present this shortage, exist already. However, they have not yet established themselves as an independent line of research in the in-company training.

Regarding the construction principle, it should be noted that the basic assumption of outcome-oriented model approaches is first training and then application (transfer as a sequence). As a result of this timely juxtaposition, training has a determining effect on the outcome. This construction principle is applied in the same way for the process-oriented research approaches: first the learning field ('learning') and then the performance field ('performance'). These basic assumptions are inappropriate for the field of in-company training.

The aim of our research, and this chapter, is to develop a theoretical framework and empirically proved model which structurally links process and outcome data with each other. Furthermore, this model should recognise the reciprocal effect of the learning and the performance field as well as the purposes of 'reflection/development' and 'control/legitimacy.'

In the following, the theoretical framework is developed. Thereafter, the empirical model, the setting and the results of the study are presented and discussed. 
THEORETICAL FRAMEWORK

The basic twin terms that are explained below for the development of the theoretical framework are 'learning field' and 'performance field,' 'transfer' and 'transformation,' 'intelligent knowledge' and 'applicable knowledge,' 'situation' and 'context' as well as 'learning performance' and 'learning transfer.'

\section{Learning Field and Performance Field}

The learning field is constituted with specific rules (e.g. 'mistakes are allowed'), roles (e.g. trainer, participant) and a specific (learning) culture of a time-limited context. This context is distinct from the time-unlimited context of the performance field (workplace) with its own specific rules (e.g. efficiency), roles (e.g. supervisor, co-worker) and (work) culture (Baldwin \& Ford, 1988). In the traditional understanding, these fields are ordered sequentially (see figure 3 ). However, we assume that both contexts operate simultaneously once the learning field is established. By ending the transfer activities in the performance field, the context learning field ends, rather than with the end of a specific training course (Rank \& Wakenhut, 1998). Of importance is not the concrete duration of a specific training, but its sustainable effect which may be different for the different participants of the same course. Hence, the individual learning field (dependent on the individual) and the institutional learning field (dependent on the organisational implementation of training) should be differentiated. The individual learning field is focused on below.

\section{Transfer and Transformation}

The term 'transfer' (Lat. 'transferre' = convey, transport, transmit) contains a movement from something to something and is used in the material world (e.g. transfer goods, airport transfer) in the same way as in the immaterial world (e.g. online money transfer, innovation transfer). These connotations are insufficient for the term 'transfer' in the context of learning: the movement from learning to application does not mean that knowledge is 'conveyed,' 'transported' or simply 'transmitted' from the learning field (as 'source') to the performance field (as 'target'). However, 'transformation' would be an appropriate term (Lat. 'transformis' = converted, transformed, changeable), since in the context of continuous in-company training, learning transfer is a context-based transformation of knowledge. With two simultaneously affected contexts - the learning field and the performance field - transfer as transformation takes place in parallel, rather than sequentially. On one hand, in both the learning and the performance field, transfer occurs as transformation; on the other hand, these transformations build resources for the respective other field ('resource' in the sense of 'raw material,' not 'source' in the sense of the 'place of origin'). Figure 3 graphically presents this understanding of transfer as transformation in contrast to the traditional understanding of transfer as sequence (Gessler, 2012, p. 371). 


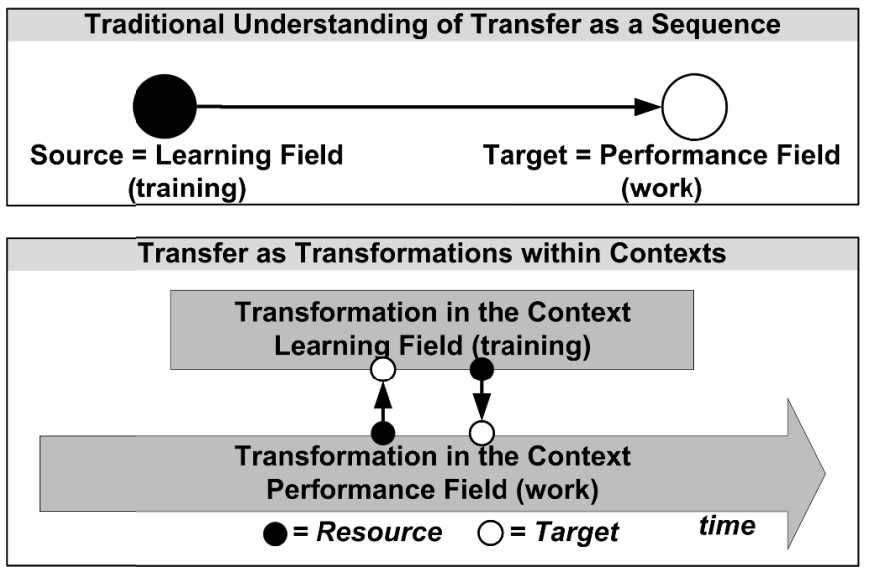

Figure 3. Different understandings of learning transfer

The basic understanding of our approach is built on the basic idea that is shared with the traditional understanding: two transformations or two learning processes (the transformation in the learning field on one side and the transformation in the performance field on the other side) influence each other. According to Anderson, Greeno, Reder and Simon (2000, p. 11), 'Both perspectives provide important insights into the processes of effective performance and learning, and neither is limited either to activity by groups or to individuals acting alone.' The combination of both perspectives constitutes the basis for determining the reciprocal relations of the learning field and the performance field. To conclude, in our understanding of transfer as transformation, the influence of the learning and performance fields is reciprocal and parallel (see Figure 3).

So far, 'resources' were mentioned in a very abstract way, which can be specified with the twin terms 'intelligent knowledge' and 'applicable knowledge.'

\section{Intelligent and Applicable Knowledge}

'Intelligent knowledge' does not mean inert, encapsulated and only mechanically applicable knowledge in which the learning situation is soldered; rather, it is meaningfully ordered, networked among each other and with many application situations, flexibly useful and adaptable in various situations (Weinert, 1997). The development of a deep understanding of phenomena, problems and problem solutions; the development of reflexivity; an interconnected and hierarchically built knowledge structure; and fast accessibility, flexible utilisation and connectivity of knowledge require (1) vertical transfer (generalisation of areaspecific knowledge which may be applicable in various situations and contexts), (2) a suitable context and (3) professional support. That is why the development of 'intelligent knowledge' is favoured, especially by trainer- 
controlled and participant-oriented trainings. Intelligent knowledge in in-company training is typically developed in the learning field with the resources (e.g. illustration) of the performance field.

The development of 'applicable knowledge' requires horisontal transfer (horisontal transfer describes the adaptation of area-specific knowledge to the demand of specific situations and contexts, which can be applicable in similar situations and contexts). The actually required elements of the systematic order of the knowledge base are to be dissolved and adapted to the requirements of the concrete situation. In so doing, the situational utilisation contexts should be considered and appropriate action schemes designed. The varying learning, thinking and action contexts are decisive. These must be self-learned according to typical and prototypical examples with a high degree of reality (Arbeitsstab Forum Bildung, 2001). Applicable knowledge is initiated in the learning field with the resources of the performance field (keyword 'trial'): prototypical in-company thinking and action contexts of the performance field are simulated (e.g. via roleplay). The problem of these simulations - even with a high degree of reality - is that they benefit from the anticipation of trainers and the participants who only simulate reality. The evaluation of the appropriateness of action schemes is, however, context related and only partly anticipatable in trainings. What applies for in-company training is that it does not necessarily have to stand still at a "possibly high degree of reality.' Applicable knowledge is initiated in the learning field with the resources of the performance field. The learning field constitutes a double resource for the performance field by combining developed intelligent and initiated applicable knowledge. The experience from the performance field flows back into the learning field as long as it is not a one-time training.

In in-company training, the learning field and the performance field constitute resources for each other. The acquisition of contentual knowledge and the knowledge application in different contexts belong together but require different teaching methods. One does not replace the other (Arbeitsstab Forum Bildung, 2001). In the next step, the terms 'situation' and 'context,' which are often simplified and used synonymously, are explained.

\section{Situation and Context}

Actions are embedded in temporal-spatial structures, i.e. in situations. The situations are in turn embedded in a network of further situations that constitute a context (Lat. 'contextus' = interwoven, connected). According to Bateson (1993, p. 25), 'Without the context, words and actions have no meaning at all.' The contexts which are relevant for our study - 'learning field' and 'performance field' differentiate themselves with regard to different elements.

Questioning the composition of the context opens up a variety of relevant cognitive (e.g. background knowledge), linguistic (e.g. co-text), situational (e.g. time), social (e.g. roles) and cultural (e.g. values) elements. The limits of a context, for which Bateson uses the term 'framework' (Bateson, 1954), appear to be fluent insofar as the sum of these elements is of importance for an understanding of the 
situation. This imaginary sum is not objectively given, but rather is marked differently, based on partly unconscious individual experience, and is changeable depending on the degree and dynamic of the reflexivity and social interaction. Nevertheless, contexts are differentiable and classifiable.

Establishing the context of the learning field requires context markings: for example, a preliminary talk, an invitation, an agenda, a specific location, a group of participants, a specific seat order, a trainer and a greeting. With the terms 'situation' and 'context,' fundamental foundations are created in order to conclude the explication of our understandings and to illustrate the specific term 'learning transfer.'

\section{Learning Performance and Learning Transfer}

Transfer as transformation in the learning and performance fields - via the resources of the other field - is either facilitated (positive transfer), inhibited (negative transfer) or not influenced (null transfer). This conceptualisation requires further elaboration and specification. Transfer as transformation is a necessary condition for learning transfer, yet it is not a sufficient condition.

Knowledge transformation and situational application over a short period are described as 'learning performance.' In contrast, the term 'learning transfer' is only appropriate when the usage of the learned takes place in a real work environment over a long period (Baldwin \& Ford, 1988). Whether the application happens immediately or after a delay is not of importance. Sustainable application is crucial. Consequently, the evaluation of learning transfer directly after the end of training seems to be questionable with regard to the requirement of a 'sustainable application.'

The time needed to gather learning transfer is dependent on various factors. If the focus of training is on the development of 'open skills,' like management capabilities, then the application in the work environment will be presumably delayed as a wide range of possible applications may be given: 'the trainee has more choice regarding whether, how, and when to transfer' (Blume et al., 2010, p. 1073). In contrast, a training with a focus on 'closed skills,' like a software application training, enables a more speedy and direct implementation, since the range of possible application is limited (ibid.).

Learning transfer implies transfer situations as well as sustainable usage of the learned in a real work environment. Without a context, transfer situations lack meaning and orientation. Figure 4 presents the extended understanding of Figure 3.

The output (learning performance in the learning field or learning performance in the performance field) does not automatically guarantee learning transfer. Nevertheless, it is a necessary condition. Only the sustainable application of the learned in the real work environment constitutes learning transfer. 


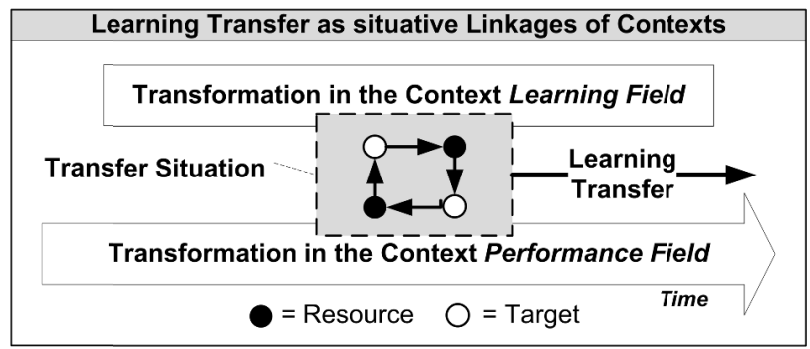

Figure 4. Theoretical framework model

\section{EMPIRICAL MODEL}

\section{Latent Variables}

If the 16 factors of LTSI are tested together with a multiple regression analysis (individual transfer results as the dependent variable), just six variables emerge as significant predictors: 'motivation to transfer,' 'personal outcomes positive,' 'personal capacity to transfer,' 'content validity,' 'peer support' and 'learner readiness.' These six predictors explain $43 \%$ variance in the individual transfer results (Bates, Kauffeld \& Holton, 2007, p. 206). The following distributions regarding the use of these variables in our model: The variables 'motivation for transfer,' 'content validity' and 'learner readiness' are the learning field, the variables 'personal capacity to transfer' the transfer situation and the variables 'personal outcomes positive' and 'peer support' are attributable to the function field. We excluded in our model the predictor 'learner readiness,' because of its $\mathrm{R}^{2}=0.01$ (see Bates, Kauffeld, \& Holton, 2007, ibid.). An empirically proven and practical variable of importance, however, is 'transfer support of the superiors' (based on Ford et al., 1992; Xiao, 1996), which is why this variable is included in our model. In our model, the variable 'personal outcomes positive' is not used, because this is operationalised in the LTSI as 'Salary increases' as well as personal and general 'remuneration' (cf. Kauffeld et al., 2008). 'Salary increases' is not a normal consequence of a training, and 'remuneration' is captured in the variables 'peer support' as well as 'support of the superiors.' For these reasons, the variable is not incorporated in our model.

Finally, the latent variables of the construct 'learning transfer' are to be specified. To determine the latent variables, we oriented ourselves around the objectives and contents of the training, as well as the domain-specific functional field - project management. The transfer of learning in relation to this scope was subdivided into three latent variables: 'professional performance' (cf. GPM Deutsche Gesellschaft für Projektmanagement \& Gessler, 2014), 'social communicative performance' (ibid.) and 'personal performance' (cf. Markus \& Sentis, 1982). 


\section{Operationalisation}

The existing LTSI items that were previously developed were used for the pre-test for the operationalisation of the latent variables of the constructs-'Context learning field,' 'Context function field' and 'Transfer situation.' For the operationalisation of the latent variables of the construct 'Knowledge transfer,' we orientated ourselves in particular around the scope of the investigation (project management). The results of a pre-test $(n=51)$ were used to examine the reliability of the inventory, the variables and items were improved with the guidance of theory, and the names of the variables were partially changed (see Table 1). The new inventory was used in the main investigation.

In Table 1, the LTSI variables and the variables used in our main investigation are compared with one another.

Table 1. Description of the model's latent variables

\begin{tabular}{|l|l|l|l|}
\hline $\begin{array}{l}\text { Latent variables } \\
\text { by Bates, Kauffeld, } \\
\text { \& Holton, 2007 }\end{array}$ & $\begin{array}{l}\text { Latent variables and number of } \\
\text { items in the main investigation }\end{array}$ & $\begin{array}{l}\text { Reference theories } \\
\text { used }\end{array}$ \\
\hline Content validity & $\begin{array}{l}\text { Transfer orientation } \\
\text { of training }\end{array}$ & 3 & $\begin{array}{l}\text { Mandl, Prenzel, \& } \\
\text { Gräsel, 1992 }\end{array}$ \\
\hline Motivation to transfer & $\begin{array}{l}\text { Transfer motivation } \\
\text { of the participants }\end{array}$ & 3 & Noe \& Schmitt, 1986 \\
\hline Peer Support & $\begin{array}{l}\text { Transfer climate } \\
\text { in the team }\end{array}$ & 3 & $\begin{array}{l}\text { Bennett, Lehman \& } \\
\text { Forst, 1999 }\end{array}$ \\
\hline- & $\begin{array}{l}\text { Transfer support } \\
\text { of the superiors }\end{array}$ & 3 & Xiao, 1996 \\
\hline $\begin{array}{l}\text { Personal capacity to } \\
\text { transfer }\end{array}$ & $\begin{array}{l}\text { Capacity of the transfer } \\
\text { situation }\end{array}$ & 4 & $\begin{array}{l}\text { Mathieu, Tannenbaum, } \\
\text { \& Salas, 1992 }\end{array}$ \\
\hline Learner readiness & - & - & - \\
\hline $\begin{array}{l}\text { Personal outcomes } \\
\text { positive }\end{array}$ & - & - & - \\
\hline $\begin{array}{l}\text { Individual transfer } \\
\text { results }\end{array}$ & Professional performance & 4 & GPM \& Gessler, 2011 \\
\cline { 2 - 3 } & $\begin{array}{l}\text { Social communicative } \\
\text { performance }\end{array}$ & 4 & \\
\cline { 2 - 3 } & Personal performance & 3 & Markus \& Sentis, 1982 \\
\hline
\end{tabular}

The latent variables are understood with respect to the meaning of the descriptions shown in Table 2. 
Table 2. Description of the model's latent variables

\begin{tabular}{|c|c|c|}
\hline Latent Variables & & Description \\
\hline $\begin{array}{l}\text { Transfer Orientation } \\
\text { of the Training }\end{array}$ & TOR & $\begin{array}{l}\text { Orientating knowledge and domain-specific } \\
\text { strategies are taught via situational tasks and } \\
\text { problems }\end{array}$ \\
\hline $\begin{array}{l}\text { Transfer Motivation } \\
\text { of the Learner }\end{array}$ & TMO & $\begin{array}{l}\text { Willingness to apply the learned in the real work } \\
\text { environment }\end{array}$ \\
\hline $\begin{array}{l}\text { Capacity of the Transfer } \\
\text { Situation }\end{array}$ & CTS & $\begin{array}{l}\text { Practical opportunities and time to actually apply } \\
\text { the learned in the work environment }\end{array}$ \\
\hline $\begin{array}{l}\text { Transfer Climate within } \\
\text { the Team }\end{array}$ & TCL & $\begin{array}{l}\text { Willingness of the team to enable and promote } \\
\text { learning and development within the team }\end{array}$ \\
\hline $\begin{array}{l}\text { Transfer Support of the } \\
\text { Supervisor }\end{array}$ & TSU & $\begin{array}{l}\text { Support by the superiors to apply the learned in } \\
\text { the real work environment }\end{array}$ \\
\hline Professional Performance & PRP & $\begin{array}{l}\text { Development of domain-specific professional } \\
\text { skills }\end{array}$ \\
\hline $\begin{array}{l}\text { Social-communication } \\
\text { Performance }\end{array}$ & SOP & $\begin{array}{l}\text { Development of domain-specific social- } \\
\text { communication skills }\end{array}$ \\
\hline Personal Performance & PEP & $\begin{array}{l}\text { Development of declarative knowledge on own's } \\
\text { domain-specific skills }\end{array}$ \\
\hline
\end{tabular}

\section{The Empirical Model}

The above-mentioned framework model (see Figure 4) has been converted into linked hypotheses (see Figure 5).

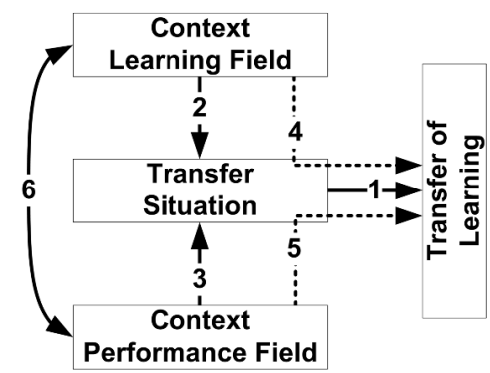

Figure 5. Linked hypotheses

The linked hypotheses are:

1. The transfer situation determines the learning transfer.

2. The transfer situation is influenced directly by the learning field.

3. The transfer situation is influenced directly by the context of the performance field. 
4. The context of the learning field indirectly influences the learning transfer by the intermediate variable transfer situation.

5. The context of the performance field indirectly influences the learning transfer by the intermediate variable transfer situation.

6. A correlation exists between the learning field and the performance field.

The hypotheses (see Figure 5) together with the latent variables (see Table 1) have been finally converted into an empirically testable model (see Figure 6).

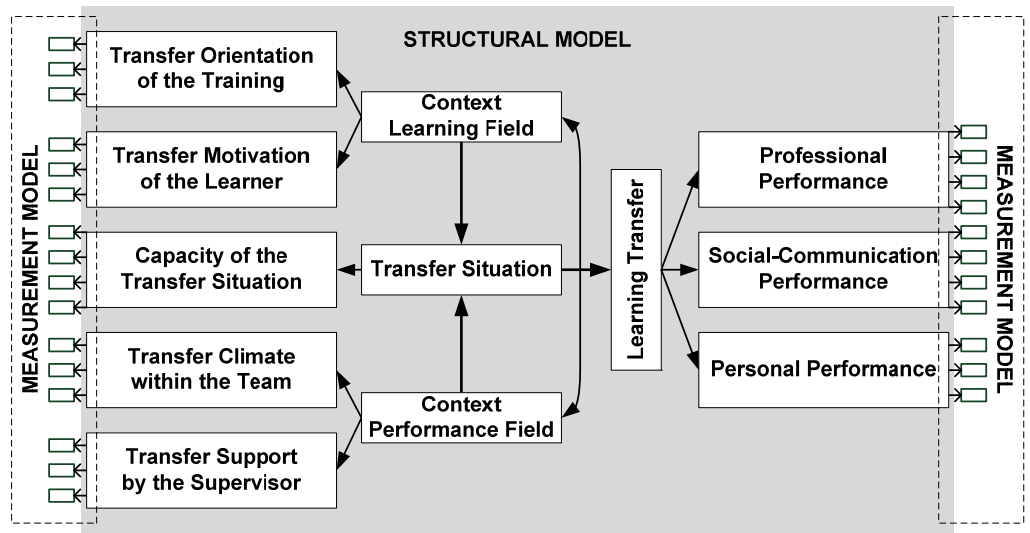

Figure 6. Structural and Measurement Model of the study

METHODOLOGY, SAMPLE AND INVENTORY

\section{Methodology}

Methodically, the objective measurement (e.g., by means of testing), the subjective assessment (e.g., by means of a survey), as well as the subjective assessment by a third party (e.g., by means of 360-degree feedback) all came into question. In this investigation, the objective measurement quickly raises the operational possibilities. For example, it is difficult to objectively measure training-working-compliance. This problem can be partly avoided if the constructs are captured via a subjective assessment as to how the individuals concerned perceive these themselves (see Hense \& Mandl, 2011, p. 252).

Since the training focused on management training and thus on 'open skills,' the amount of time between training and data collection in the practice was not allowed to be too short. In the meta-analysis at the level of 'behavioural criteria,' Arthur et al. (2003, p. 242) identified an average time period of 133.59 days (SD: 142.24), or approximately 6.5 months, after the completion of training. Based on this value, we allotted 3 to 9 months for the entire investigation period after the completion of training. 


\section{Sample}

The observed project management training covers a total of 11 days, divided into four modules with a total duration of 4 months. It is implemented countrywide according to a unified training concept which is taught by various trainers. For authorisation, all the trainers go through a comprehensive qualification and certification procedure. With regard to identification of the effects, this setting is important. Training that does not include these quality assurance procedures presumably shows another weighing of predictors. A total of 2,345 former participants of this training were invited in October 2010 to take part in an online questionnaire. The investigation took place 3 to 9 months after the individual end of the training (M: 6 months, SD: 1.7). The response rate was $27 \%(\mathrm{n}=633)$ and the average age was 38.4 years (SD: 7.7 ). The proportion of men was $77.3 \%$ $(n=489)$, while women constituted $22.7 \%(n=144)$.

\section{Inventory}

A summary of the characteristics of inventory used is presented in Table 3.

Table 3. Characteristic of the inventory

\begin{tabular}{|l|l|l|l|l|c|}
\hline Variables & Example item and number of items & M & SD & $\boldsymbol{\alpha}$ \\
\hline $\begin{array}{l}\text { TOR: Transfer } \\
\text { orientation } \\
\text { of training }\end{array}$ & $\begin{array}{l}\text { During training, we addressed problems } \\
\text { with exercises that are similar to the } \\
\text { demands of my work. }\end{array}$ & 3 & 3.94 & .86 & .72 \\
\hline $\begin{array}{l}\text { TMO: Transfer } \\
\text { motivation } \\
\text { of the participants }\end{array}$ & $\begin{array}{l}\text { During training, it was already clear to me } \\
\text { that I wanted to apply what I had learned } \\
\text { in my work. }\end{array}$ & 3 & 4.39 & .59 & .92 \\
\hline $\begin{array}{l}\text { CTS: Capacity } \\
\text { of the transfer } \\
\text { situation }\end{array}$ & $\begin{array}{l}\text { There were situations and opportunities in } \\
\text { my work to apply what I learned. }\end{array}$ & 4 & 3.62 & 1.01 & .70 \\
\hline $\begin{array}{l}\text { TCL: Transfer } \\
\text { climate } \\
\text { in the team }\end{array}$ & $\begin{array}{l}\text { In our team, we give each other tips and } \\
\text { suggestions in order to continuously } \\
\text { improve the way in which we work. }\end{array}$ & 3 & 3.62 & 1.10 & .91 \\
\hline $\begin{array}{l}\text { TSU: Transfer } \\
\text { support } \\
\text { of the superiors }\end{array}$ & $\begin{array}{l}\text { I had a conversation with my boss about } \\
\text { how to incorporate what I learned in my } \\
\text { work. }\end{array}$ & 3 & 2.08 & 1.15 & .81 \\
\hline $\begin{array}{l}\text { PRP: Professional } \\
\text { performance }\end{array}$ & $\begin{array}{l}\text { I monitor the risks in my projects more } \\
\text { closely now than before the training. }\end{array}$ & 4 & 3.63 & .94 & .84 \\
\hline $\begin{array}{l}\text { SOP: Social } \\
\text { communicative } \\
\text { performance }\end{array}$ & $\begin{array}{l}\text { I pay more attention today to binding } \\
\text { agreements with my client than before the } \\
\text { training. }\end{array}$ & 4 & 3.68 & .98 & .83 \\
\hline $\begin{array}{l}\text { PEP: Personal } \\
\text { performance }\end{array}$ & $\begin{array}{l}\text { I can evaluate my strengths and } \\
\text { weaknesses better now than before the } \\
\text { training. }\end{array}$ & 3 & 3.61 & 1.05 & .89 \\
\hline $\begin{array}{l}\text { Notes: N = 633; M arithmetic means, scale from 1 = 'do not agree' to 5 'agree'; } \\
\text { SD = standard deviation; } \alpha=\text { internal consistency. }\end{array}$ & \\
\hline
\end{tabular}


The scales point to internal consistency values of .70 up to .92 acceptable reliability values.

\section{RESULTS}

The structural model is built on a system of six hypotheses. The model shows a good fit to the data $(\mathrm{p}<.001)$. Figure 7 presents the results.

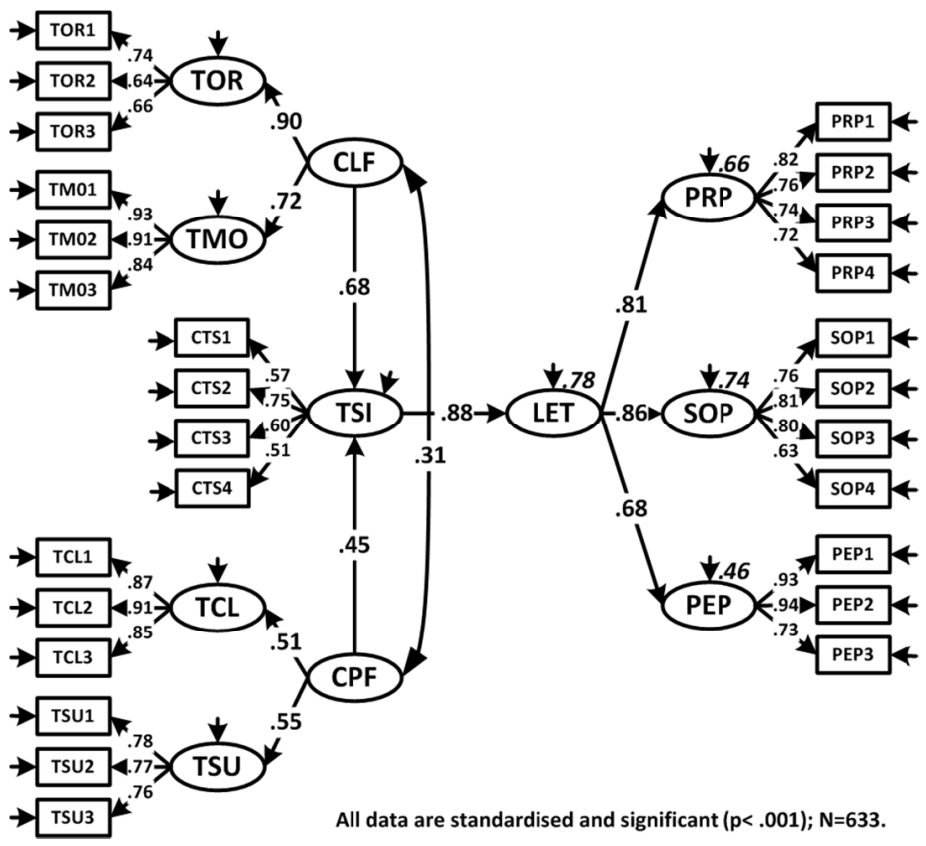

Figure 7. Parameters of the structural and measurement model

The structural model derives from a theoretical pre-understanding, which - as a necessary condition for learning transfer - defines the situational linkage of transformative contexts (= learning outcome). However, as opposed to the term 'learning outcome,' the term 'learning transfer' requires applying the learned in the real work environment for a specific period. The test of the framework model shows a good fit with the empirical data $(\chi 2=742.91$, $\mathrm{df}=313, \chi 2 / \mathrm{df}=2.37$; CFI $=.955$; RMSEA $=.047$; SRMR $=.052$ ), and the explanation rate of the variance of learning transfer is very high: $78 \%$ of the variance of the self-reported learning transfer can be explained via the framework model $(\mathrm{p}<.001)$. 


\section{DISCUSSION \& CONCLUSION}

The structural model of the latent variables has been tested and validated. The transfer orientation of the training, the transfer motivation of the learner, the transfer climate within the team, the transfer support by the supervisor and the capacity of the transfer situation have been identified as predictors of learning transfer from between 3 to 9 months after the end of a training.

The results are based on self-assessment only. This can be viewed both positively and negatively. In the context of the study presented, it is assumed that the participants are experts in their field and therefore they are able to realistically assess their learning transfer. Thus, self-assessment is seen as a potential means of further assessing the effectiveness of continuing vocational training (Sonntag \& Schäfer-Rauser, 1993). Moreover, future research should investigate whether the results are replicable in other fields of continuing vocational training apart from project management, and additional qualitative research is desirable to better explain the quantitative results.

Some questions remain unanswered. The results say nothing about a possible transfer of learning, which already takes place alongside the training participation in continuing vocational training. Additionally, the transfer process over time should be investigated in order to test the timely development of the transformation.

Recently, Hinrichs has carried out research examining the question whether learning transfer already occurs parallel to continuing vocational training. 299 participants from 82 German project management training courses nationwide were asked about their increase in work performance after 6 (out of a total of 11) training days. The online questionnaire was based on the presented study and was further developed according to the different research design.

The results point out that learning transfer in the context of continuing vocational training is not to be seen as a phenomenon which only occurs after the end of training or several months after the end of a training program. An application of the learned rather occurs as a development process in the temporal progress of the training course. Relating to learning transfer in parallel with continuing vocational training, Hinrichs (2014) has introduced a new term: collateral learning transfer.

Despite the different time points of data collection (Gessler: 3-9 months after the training; Hinrichs: parallel to the training) Gessler's (2012) structural model was confirmed in its basic structure. The empirical results of both studies highlight the central importance of the performance field (work environment) for transfer of learning to occur. To improve the work performance, the transfer orientation of the training and the transfer motivation of the learner are highly influential.

Thus, learning transfer in continuing vocational training should be considered as a context-related transformation of knowledge where both the learning field (training) and the performance field (work environment) form resources for each other. 


\section{REFERENCES}

Anderson, J. R., Greeno, J. G., Reder, L. M., \& Simon, H. A. (2000). Perspectives on learning, thinking, and activity. Educational Researcher, 29(4), 11-13.

Arbeitsstab Forum Bildung. (2001). Bildungs- und Qualifikationsziele von Morgen: Vorläufige Leitsätze des Forum Bildung. Materialien des Forums Bildung 5. Bonn: Arbeitsstab Forum Bildung in der Geschäftsstelle der Bund-Länder-Kommission für Bildungsplanung und Forschungsförderung.

Baldwin, T. T., \& Ford, J. K. (1988). Transfer of training: A review and directions for future research. Personnel Psychology, 41(1), 63-105.

Bates, R., Kauffeld, S., \& Holton, E. F. (2007). Examining the factor structure and predictive ability of the German-version of the Learning Transfer Systems Inventory. Journal of European Industrial Training, 31(3), 195-211.

Bateson, G. (1954). Eine Theorie des Spiels und der Phantasie. In G. Bateson (1994), Ökologie des Geistes: Anthropologische, psychologische, biologische und epistemologische Perspektiven $\left(5^{\text {th }}\right.$ ed., pp. 241-261). Frankfurt am Main: Suhrkamp.

Bateson, G. (1993). Geist und Natur: Eine notwendige Einheit ( $3^{\text {rd }}$ ed.). Frankfurt am Main: Suhrkamp.

Bennett, J. B., Lehman, W. E. K., \& Forst, J. K. (1999). Change, transfer climate, and customer orientation: A contextual model and analysis of change-driven training. Group Organization Management, 24(2), 188-216.

Beywl, W. (2006). Demokratie braucht wirkungsorientierte Evaluation: Entwicklungspfade im Kontext der Kinder- und Jugendhilfe. In DJI (Eds.), Wirkungsevaluation in der Kinder- und Jugendhilfe: Einblicke in die Evaluationspraxis. München: Deutsches Jugendinstitut (DJI).

Blume, B. D., Ford, J. K., Baldwin, T. T., \& Huang, J. L. (2010). Transfer of training: A meta-analytic review. Journal of Management, 36(4), 1065-1105.

Cheng, E. W. L., \& Ho, D. C. K. (2001). A review of transfer of training studies in the past decade. Personnel Review, 30(1), 102-118.

Descy, P., \& Tessaring, M. (2006). Der Wert des Lernens: Evaluation und Wirkung von Bildung und Ausbildung. Dritter Bericht zum aktuellen Stand der Berufsbildungsforschung in Europa Synthesebericht. CEDEFOP Reference Series 66. Luxemburg: Amt für amtliche Veröffentlichungen der Europäischen Gemeinschaften.

Diesner, I., \& Seufert, S. (2010). Trendstudie 2010: Herausforderungen für das Bildungsmanagement in Unternehmen. St. Gallen: SCIL Swiss Centre for Innovations in Learning.

Donabedian, A. (1966). Evaluating the quality of medical care. The Milbank Memorial Fund Quarterly, Reprint 2005, 83(4), 691-729. (Original 1966: The Milbank Memorial Fund Quarterly, 44(3), $166-$ 203)

Gessler, M. (2012). Lerntransfer in der beruflichen Weiterbildung - empirische Prüfung eines integrierten Rahmenmodells mittels Strukturgleichungsmodellierung. Zeitschrift für Berufs- und Wirtschaftspädagogik, 108(3) 362-393.

GPM Deutsche Gesellschaft für Projektmanagement, \& Gessler, M. (Eds.). (2011). Kompetenzbasiertes Projektmanagement (PM3): Handbuch für die Projektarbeit, Qualifizierung und Zertifizierung auf Basis der IPMA Competence Baseline 3 ( $4^{\text {th }}$ ed.). Nuremberg: GPM.

Hense, J., \& Mandl, H. (2011). Transfer in der beruflichen Weiterbildung. In O. Zlatkin-Troitschanskaia (Ed.), Stationen Empirischer Bildungsforschung (pp. 249-263). Wiesbaden: VS Verlag.

Hinrichs, A. C. (2014). Predictors of collateral learning transfer in continuing vocational training. International Journal for Research in Vocational Education and Training, 1(1), 35-56.

Holton, E. F. (1996). The flawed four level evaluation model. Human Resource Development Quarterly, $7(1), 5-21$.

Holton, E. F. (2005). Holton's evaluation model: New evidence and construct elaborations. Advances in Developing Human Resources, 7(1), 37-54.

Holton, E. F., Bates, R., \& Ruona, W. (2000). Development of a generalized learning transfer system inventory. Human Resource Development Quarterly, 11(4), 333-360. 


\title{
M. GESSLER \& A.-C. HINRICHS
}

Kauffeld, S. (2010). Nachhaltige Weiterbildung: Betriebliche Seminare und Trainings entwickeln, Erfolge messen, Transfer sichern. Berlin: Springer.

Kauffeld, S., Bates, R., Holton, E. F., \& Müller, A. C. (2008). Das deutsche Lerntransfer-SystemInventar (GLTSI): Psychometrische Überprüfung der deutschsprachigen Version. Zeitschrift für Personalpsychologie, 7(2), 50-69.

Kirkpatrick, J. D., \& Kirkpatrick, D. L. (2006). Evaluating training programs: The four levels ( $3^{\text {rd }}$ ed.). San Francisco: Berrett-Koehler.

Mandl, H., Prenzel, M., \& Gräsel, C. (1992). Das Problem des Lerntransfers in der betrieblichen Weiterbildung. Unterrichtswissenschaft: Zeitschrift für Lernforschung, 20(2), 126-143.

Markus, G., \& Sentis, K. (1982). The self in social information processing. In J. Suls (Ed.), Psychological Perspectives on the Self (pp. 41-70). Hillsdale, NJ: Erlbaum.

Mathieu, J. E., Tannenbaum, S. I., \& Salas, E. (1992). Influences on individual and situational characteristics on measures of training effectiveness. Academy of Management Journal, 35(4), 828847.

Noe, R. A., \& Schmitt, N. (1986). The influence of trainee attitudes on training effectiveness: Test of a model. Personnel Psychology, 39(3), 497-523.

Philipps, J. J., \& Philipps, P. P. (2010). Show me the money: How to determine ROI in people, projects and programs. San Francisco: Berrett-Koehler Publishers.

Rank, B., \& Wakenhut, R. (1998). Ein Bedingungsmodell des Praxistransfers. In B. Rank \& R. Wakenhut (Eds.), Sicherung des Praxistransfers im Führungskräftetraining (pp. 11-30). München: Mering.

Sonntag, K., \& Schäfer-Rauser, U. (1993). Selbsteinschätzung beruflicher Kompetenzen bei der Evaluation von Bildungsmaßnahmen. Zeitschrift für Arbeits- und Organisationspsychologie, 37, $163-171$.

Stufflebeam, D. L. (1972). Evaluation als Entscheidungshilfe. In C. Wulf (Ed.), Evaluation: Beschreibung und Bewertung von Unterricht, Curricula und Schulversuchen (pp. 113-145). München: Piper.

Weinert, F. E. (1997). Ansprüche an das Lernen in der heutigen Zeit. In M.f.S.u.W.d.L. NordrheinWestfalen (Ed.), Fächerübergreifendes Arbeiten: Bilanz und Perspektiven. Dokumentation der landesweiten Fachtagung im Rahmen des Dialogs über die Denkschrift der Bildungskommission NRW Zukunft der Bildung - Schule der Zukunft (pp. 12-26). Frechen: Ritterbach.

Xiao, J. (1996). The relationship between organizational factors and the transfer of training in the electronics industry in Shenzhen, China. Human Resources Development Quarterly, 7(1), 55-74.

\author{
Michael Gessler \\ Institute of Technology and Education \\ University Bremen, Germany
}

Anja-Christina Hinrichs

Mubea Muhr and Bender KG

Attendorn, Germany 
SUSANNE DAU

\title{
5. KNOWLEDGE DEVELOPMENT IN INTERNSHIP
}

\author{
A Case-study of Students' Access to Tacit and Explicit Knowledge in \\ Blended Learning (BL) Programmes
}

\begin{abstract}
INTRODUCTION
Knowledge in workplaces and within the professions is often described as procedural, processual (Guzman, 2009) and organisation-specific, or as know-how which tends to be used tacitly (Polanyi, 1966). Frequently, reference is made to theoretical perspectives on how professionals develop competencies (Benner, 1984; Dreyfus \& Dreyfus, 1991) and how they think in actions (Schön, 1983). Apprenticeship learning offers access to these kinds of knowledge and competences, but is also challenged and underestimated.

For instance, apprenticeship learning in internship becomes challenged by the theoretical college based learning and by the traditions of theoretical explicit knowledge having precedence, to the detriment of more tacit practice based knowledge (Dau \& Nielsen, 2011). Despite these challenges, internship in undergraduate education is still regarded as a space for workplace learning including elements of apprenticeship. Apprenticeship is a traditional method in internship where learning is achieved through observations, individualised coaching and practice (Collins, Brown, \& Newman, 1987). However, learning in internship seems to have moved towards expanding schooling, giving up principles of apprenticeship in workplace learning (Resnick, 1987, p. 17). Furthermore, curricula and college-based goals tend to colonise or predetermine periods of internship and workplace learning (Heggen, 1995, p. 17).

The purpose of the chapter is to shed light on how these challenges and tendencies affect students' access to tacit and explicit knowledge and the professions' knowledge development. To address these challenges, the chapter examines the question: How might periods of internship, offering different kinds of access to tacit and explicit knowledge by apprenticeship and reflection, have consequences for both students' learning and the professions' knowledge development?

The chapter presents an empirical case study of internship learning by revealing data from two Blended Learning (BL) programmes at University College North (UCN) in Denmark. The programmes offer an integration of face-to-face and online approaches (Garrison \& Vaughan, 2008). The programmes combine
\end{abstract}


academic learning and vocational learning that give access to the labour market as well as higher education also conceptualised as a hybrid qualification (Davey \& Fuller, 2010; Jørgensen \& Lindvig, 2011).

Before I return to the empirical data presented in the cases, I will make a conceptual clarification of what constitutes the field being investigated in relation to: reflection as a part of workplace learning in internship, the use of information technology (IT) as a part of internship learning, and knowledge development in the setting.

\section{Reflection - A Part of Workplace Learning in Internship}

Reflection is an element in the development of knowledge of activities of daily living (Schön, 1983) and thus contributes to the legitimation of student membership in a community of practice (COP) (Lave, 2011).

The use of workplace learning involving reflection seems to be effective as it entails "hands on" problem-solving and guided learner reflection (Dalton, 2004). Accordingly, it seems to link group interactions, real life experiences and guided reflections (Harrison, 2006). Participation, experience and reflection are thereby seen as drivers of learning.

Reflection is described by Schön (1987) in terms of knowing-in-action (tacit embodied knowledge) and reflection-in-action (partly tacit). Reflection, however, also occurs more explicit as reflection-on-reflection-in-action (Schön, 1983). The latter is most significant in the education of undergraduates and in students' periods of internship. This will be shown in the cases presented later.

\section{Use of Information Technology (IT) - A Part of Internship Learning}

Reflection in internship may be extended by the use of IT, as practical knowledge sharing is combined with other sources of online knowledge. Extended use of IT is also a matter in the two educations where blended learning is predominantly considered as an integration of thoughtful and complementary face-to-face and online approaches (Garrison \& Vaughan, 2008).

The use of IT, as a part of blended learning, at UCN is partially founded on theories of social constructivism. This frame of reference implies learning as an active social process where an individual's acquisition of new knowledge and skills is influenced and supported by the social environment (Mayes \& de Freitas, 2004). Accordingly, learning seems to be founded in a situational, social and cultural practice in both radiography and teacher education (Nyvang \& Dau, 2013).

\section{Knowledge Development in Setting}

Learning is a process of development among individuals, communities (Illeris, 2013) and organisations (Nonaka \& Takeuchi, 1995). Knowledge creation is, according to Nonaka and Takeuchi (1995), a spiralling process of interaction 
between tacit and explicit knowledge, which leads to the development of new knowledge, as pointed out in the SECI-model (Socialisation, Externalisation, Combination and Internalisation) and illustrated in Figure 1. I have enriched the model by inserting text boxes that illustrate the concepts related to learning-inpractice as discussed above. However, this is still in accordance with Nonaka and Takeuchi's use of the figure.

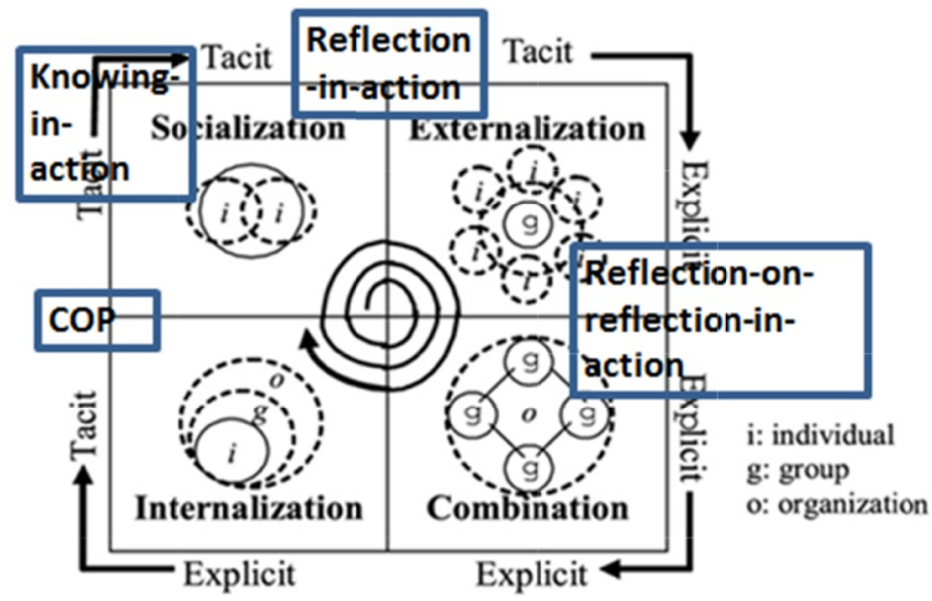

Figure 1. SECI model. Source: Adapted from Nonaka and Konno (1998, p. 43)

The model captures both tacit and more traditional explicit knowledge. Therefore, the model becomes valuable for investigating knowledge development in internship, as it illustrates both elements of apprenticeship and reflection.

Students can take part in socialisation through peripheral and full participation in the community of practice (COP) by getting access to tacit and situated knowledge (left side of Figure 1). This access also relates to apprenticeship (Nielsen \& Kvale, 1999, p.15). Furthermore, tacit knowledge is gained through experience in terms of observation, participations and actions as the foundation for knowing-in-action and reflection-in-action (left side towards the middle in Figure 1).

In the process of externalisation of tacit knowledge, more explicit dialogues and reflections are added. Externalisation is a process of concept creation triggered by dialogue or collective sharing of reflection for instance by reflection-on-reflectionin-action (right side of Figure 1).

In the combination phase of knowledge development, IT is used to combine knowledge in a broader sense. For instance, in the use of Web 2.0, technologies combining knowledge across settings extend learning in practice (Ryberg \& Dau, 2013). Finally, shared and combined knowledge can be internalised and restored in COP, developing the professionals' activities (the left side bottom of Figure 1). 
Before I return to the cases showing how periods of internship are related to the process of knowledge development, I will clarify the design and methodology which constitute this research.

\section{DESIGN AND METHODOLOGY}

The data collection, as well as methodical processing, has its main argument in critical hermeneutics with a pragmatic oriented approach to answering the research question. The empirical basis consists of both qualitative and quantitative data with the emphasis on the qualitative part.

The methodological approach is based on knowledge as context-specific, relational, dynamic, and emerging in social communities. This is an approach to knowledge-based humanities that is in accordance with the definition of knowledge described by Nonaka and Nishiguchi as "a dynamic human process of justifying personal belief toward the "truth" (Nonaka \& Nishiguchi, 2001, p. 14).

The two cases are radiography and teacher training. I have tried to achieve variation by the selection of educations that have two different approaches. Radiography is a relational-technical profession where an attempt is made to integrate the use of IT during the internship. In contrast, teacher education is articulated solely as a relational profession valuing face-to-face relationships. The use of two varied cases raises perspectives on different problems in periods of internship.

The empirical evidence which underlies the chapter is a survey (S) and eleven focus group interviews. Interviews took place two times during the first year of students' enrolment. In the following, I reveal the design and methodological considerations concerning the survey and focus group interviews.

\section{Online Survey among Students}

The online questionnaire gathered data concerning students' IT resources, experience and use of different types of online resources, preferences in relation to teaching and learning and use of or intention of using training stations. In the structuring of questions a Likert scale supplemented by multiple choice questions regarding demographic information was used.

With a response rate of 59\% for radiography and teacher training, the number of informants was $35(n=35)$ out of 59 students enrolled in the two programmes (32 teachers and 27 radiography students). Only results directly relevant in qualifying the cases are included, as data of more secondary importance are described elsewhere by Nyvang and Dau (2013) and Dau (2013).

\section{Focus Group Interviews}

Seven focus group interviews (FI) were conducted after half a year (FI1) and again after one year of the students' enrolment in education (FI2). The focus groups were 
represented by four to eight participants with some minor deviations. The groups were: teacher students (TS), radiography students (RS), radiography lecturers (RL), teacher lecturers (TL), radiography internship supervisors (RIS), teacher internship supervisors (TIS) and mentors (M). The interviews over the period included the same groups with some minor changes. Mentors' and lecturers' statements in the second interview are deselected in this paper, as they did not add any significant data to the question raised.

Selection of informants was based on representation, variation in gender and residence and was carried out by "snowballing." The focus group interviews were constructed giving respondents opportunities to develop perspectives and experiences freely within the group.

Three main themes structured the focus group interviews: 1) blended learning, 2) development of knowledge in education and 3) spaces and settings of learning. Open ended questions were used, supplied by requests of examples and verification of answers among informants.

Informants had signed a confidentiality agreement concerning the obligation of secrecy. All focus group interviews were fully transcribed. Internship specific data from the focus group interviews are included as quotes in the findings below.

\section{Critical Hermeneutic Analysis of Empirical Data - A Foundation for the Conduction of the Cases}

The critical-hermeneutical method is inspired by Riceour's (1984, 1989) interpretive description of the threefold mimesis through textual prefiguration, configuration and refiguration. This interpretation method allows putting expressed narratives emerging from focus group interviews and the survey into a textual form and process the data both in relation to the whole and the parts of the cases. It is a process of textual imitation and structuring adding explanatory elements in the interpretation of informants' perspectives (see Dau, 2013; Nyvang $\&$ Dau, 2013). The explanatory elements are composed of theory and empirical research context.

\section{FINDINGS}

The cases of radiography and teacher education are constructed around selected data from the online survey (S) and the interviews (FI). Quotations are not personified. The interpretation of empirical data integrates perspectives from theory and empirical research context as described above.

The analysis of the cases of radiography and teacher education is structured around the following themes: workplace learning in internship, IT as a part of the internship and finally learning and knowledge development in the setting. 


\section{Case 1: Internship in radiography}

Radiography students (RS) are in internship for one week in their first semester and two periods of ten weeks in their third semester. The process of internship in radiography addresses experiences and reflection combining knowledge of radiography and technology with a human-centred approach, meaning the ability to give the patient the best possible experience, care and empathy.

Access to workplace learning. The periods of internship are structured around apprenticeship. Students are allowed to observe and imitate "more skilled" practitioners in authentic situations. The students get access to tacit knowledge through these observations but also through instruction and training of skills. Transitions throughout the period from a position of a legitimate periphery participant towards a more skilled and equally accepted participant in the community of professionals (Lave \& Wenger, 1991) seem available. The periphery position is expressed like this:

But also in the beginning, I did not know where to put myself. (RS, FI1)

The function of skilled practitioners as role-models in internship is supported by the survey data, according to which $75 \%$ of the students prefer learning by observing and imitating and $88 \%$ learning by being in a COP. COP gives students access to tacit knowledge embedded in the professionals' sociality and activities. As expressed by a student:

Now, I have been on a short internship, and it was just about watching and then doing just a little. (RS, FI1)

The interplay between the novice and the expert highlights the socio-cultural and social construction of knowledge (Billett, 2001) in workplaces, where the student benefits from more experienced practitioners. Students' knowledge derives through participating in real life practice using their senses. However, sometimes disruptions and work pressure occur.

It was difficult, there ... because, often we had over 85 patients a day in the rooms ... we were pressed. (RS, FI2)

This kind of production pressure and the influence on knowledge development were also a matter of concern among lecturers:

There is a lot of production pressure in practice ... and the student can very easily be pulled into that ... there is not much tradition of actual development. (RL, FI1)

Without explication, externalisation and dialog of these experiences students' knowledge development is at risk of stagnation in socialisation.

Despite the pressure, formal and informal reflection sessions between the radiography internship supervisor and students took place. Those reflection sessions might indicate some progression in the knowledge development processes, 
considering that the explicit dialogue taking place in such sessions is supposed to make the tacit knowledge explicit and combined. The survey indicated that reflections such as reflection-on-actions were also regarded as important for more than a half of the students (56\%). An internship supervisor in radiography explains:

Reflection is the most important tool ... together with practical skills ... we do have reflection-exercises ... it helps them be aware of all the facets. (RIS, FI1)

It is a combination of apprenticeship and action and reflection ... we have to be role-models and show them how. (RIS, FI1)

These statements might indicate the existence of different kinds of reflections, e.g. reflection-on-reflection-in-action, whereas students are trained through simple reflection-exercises.

Besides reflections, nonverbal instructions and practical activities are valued. Those actions can be foundational for knowing-in-action (Schön, 1983) and for the access to tacit knowledge.

If you are to learn how to make a photograph, then you have to feel the patient ... you must touch and have the device in your hands ... It is just a craft. (RIS, FI1)

Radiography students access embodied experiences and professional craft through training and problem solving - experiences that can be internalised in students' future practice.

It is about getting the most experience possible ... in practice. (RIS, FI2)

Thereby, the workplace offers opportunities to gain specific professional practice based knowledge and experiences by apprenticeship, guided reflections and acquisitions of embodied skills by craftsmanship.

IT - an incipient part of practice. Reflections seem to be extended by the use of technology in periods of internship, for instance, when students search for guidelines and instruction on the internet.

Then you can go in and Google it ... Google is the road to knowledge ... If I looked something up on Google, then I went and talked to the other professionals to discuss if it was valid. (RS, FI2)

The use of online media seems to support learning and making sense of the immediate situations. IT becomes a tool to link codified knowledge from internet sources with situated experiences. Radiography students' choice of Google indicates that students use easily accessed web-resources, but also the professionals regional database for procedures, guidelines and instructions.

They seek knowledge at PRI [procedures, guidelines and instructions] and on the internet. (RIS, FI2) 
Technology is, furthermore, used for cooperation across hospitals in the students' second period of internship.

We had a virtual seminar using Adobe Connect but suddenly Adobe Connect broke down and shifted to It's-Learning. We were two groups of three students [from different hospitals] ... we had a really good discussion. (RS, FI2)

The above quotation illustrates positive experiences of online collaboration and knowledge sharing despite some technical problems. Such online collaboration among peers might be a starting point for using other professional online networks combining knowledge.

Challenges in the development of practice. In the first period of internship radiography students are newcomers and busy observing and absorbing impressions. In this period knowledge development seemed linked exclusively to the individual student's own learning. Radiography students' contribution to knowledge development in professional practice is first recognised later on in training:

Now we only have first and second semester students ... we miss some higher level students ... to give feedback ... They become a part of the development. (RIS, FI1)

The acknowledgement of radiography students' contribution, however, becomes challenged by existing work conditions. The production pressure and working routines are difficult to change and students face the hierarchy in their attempt to add knowledge to the profession:

Sometimes students are more focused ... and can see alternatives, where the older radiographers just do as they have always done ... but you cannot, as a student, just intrude and say: "listen, try to do it like this." (RS, FI2)

The students seem to be in a neither/nor and both/and situation as described by Akkerman and Bakker (2011), as students' knowledge development is both dependent on and limited by their positions in COP. Although students can see alternatives to existing practice, these are challenged by hierarchy and working conditions. A consequence might be a reproduction of practice instead of internalisation of new knowledge. Thereby, the full potential of the knowledge development process (SECI) seems limited.

Nevertheless, radiography students socialise, externalise and combine their knowledge to some extent. Students' own knowledge development is facilitated by opportunities in real practice. Through students' membership in the community of practice they gain insight into radiography. 


\section{Case 2: Internship in teacher education}

Teacher students are in internship in a short observation period and two periods of seven to nine weeks during their first year of enrolment. The purpose is offering students practical and theoretical experiencing as a prerequisite for their own development and learning.

Apprenticeship is underestimated. Despite $68 \%$ of the students agreeing that they learn by having a practitioner to guide and mentor them $(\mathrm{S})$, the internship is primarily a student-based activity. The periods of internship are structured around students' achievement of personalised experiences. Students are "alone" in planning, managing and having classes in the municipal school. Presumably, it is partly a consequence of the curricula aiming at training certain skills and fulfilling predetermined goals which might hinder teacher students' inclusion in the COP (Dau \& Nielsen, 2009; Heggen, 1995). As an internship supervisor puts it:

Something they have to try out, what they have learnt in Danish lessons from UCN ... Something they may use for forthcoming assignments. (TIS, FI2)

Consequently, this understanding of a curriculum directed internship prevents students from accessing "real" professional knowledge and prevents them from being a full member of the COP. An internship supervisor reflects on this:

But I thought ... that you really have to think a little beyond that ... we are in a close cooperation ... it is actually another teacher role if you planned a course together with students. Then it is not only the students' internship experience. (TIS, FI2)

An internship supervisor suggested a new type of relevant student collaboration. This finding is consistent with results from a case-study carried out by Roth, Masciotra and Boyd (1999), where they revealed how co-teaching is essential to novice teachers' mastery of study. This is apparently also the preference among many teacher students as $79 \%$ agree that they learn by acting in a COP (S).

Another limitation of access to workplace learning and tacit knowledge dimensions is the exclusion of apprenticeship as a basis for learning in the professional practice.

It does not give much meaning trying to instruct them ... this is not an apprenticeship profession ... our task as a supervisor is to ask critical questions ... they have to become reflective. (TIS, FI1)

The access to tacit knowledge embedded in the professional practice seems predominantly available in the short period of internship observation at the beginning of teacher students' enrolment.

The first week when we were out [in the observation internship] we were allowed to investigate how ... the professional teacher ... she taught, and we were allowed to watch her. (TS, FI2) 
In general the teacher students' gaining individual experiences take precedence over apprenticeship. Nonetheless, teacher students' experiences are regarded as important.

It is said that you will only begin to become a teacher when you get out ... when you get some experience. (TIS, FI1)

Experience and reflection on experience are thereby the primary approaches students face while they are in an internship at municipal schools. This is a process where externalisation is prioritised. However, this externalisation predominantly concerns the reflection of students' own experiences and planning and not a joint venture of cooperation and co-action together with the professionals.

IT in internship - students apply tools, but lacks access to knowledge in the COP. The students' access to blended learning and the use of technology in municipal school seems restricted, because they are left to their own teaching experiences rather than the professions. According to an internship supervisor, teacher students tend to reproduce prior school experiences in classroom teaching.

I do not think [students use online technology] ... When you come here as a first year student, you only refer back to how your own education has been... and it is paper and blackboard. (TIS, FI1)

This lack of technology use among students might be due to the lack of apprenticeship, as students miss observations of professionals' technology use.

We use IT a lot. (TIS, FI1)

This has become problematic since the access to supervisors' competences, e.g. in the use of Flipped Classroom and in the matter of IT integration, seems absent.

If a great deal of competence development is rooted in learning from other people, as Eraut (2007) describes, then this exclusion seems inappropriate. However, teacher students occasionally access learning management platforms and online tools available in practice:

They have been provided with a blog ... they can make their teaching and their Prezi from there. (TIS, FI2)

Teacher students are also aware of Danish online resources as a place to gain knowledge and tools for teaching:

We were using the Danish teachers associations' homepage ... we were also looking at a forum [website] ... with our supervisor ... where other professionals placed their training materials ... it was very usable. (TS, FI2)

Students' use of technology is mainly as a didactic tool and a supplement in the teaching of pupils, and technology does not seem to be rooted in collaboration with professionals or peers across settings. Thereby, the combination phase (Figure 1) seems weakened. One reason might be a lack of knowledge about how technology 
may support advanced workplace learning and the professional development of teachers.

Steps for development of practice. Internship is a unique place for students' own knowledge development as professionals (Carter \& Francis, 2001). It is something, that mostly seems to be gained through teacher students' own experiences of teaching instead of through apprenticeship. A lecturer describes how practice affords knowledge:

It is a process of formation ... when they enter school, they have four seconds to make an ethical assessment ... they must have the ability to make a qualified professional judgment, and they can only learn this in practice [internship] ... it is the complexity. (TL, FI1)

The professional judgements are achieved through experience or, as Harris, Willis, Simon and Collins (2001) describe it, through a process of formation as a kind of just-in-time learning immediately relevant for the learners.

Occasionally, however, teacher students contribute to the communities of practice knowledge base by offering new tools for professional practice.

We made a grammar-book ... we put it on the teachers' forum [online platform]. (TS, FI2)

The tool developed might to some extend contribute to the existing explicit knowledge in the COP, although the tool is exclusively developed by teacher students. However, the impact of the tool is unclear.

\section{RESULTS AND DISCUSSION}

I have raised the question: how might periods of internship, offering different kinds of access to tacit and explicit knowledge by apprenticeship and reflection, have consequences for both students' learning and the professions' knowledge development? The findings revealed different approaches, conditions and use of apprenticeship and reflection to have implications for student learning and the development of the professions.

Radiography students are given access to tacit knowledge through apprenticeship and socialisation. They are offered an opportunity to make explicit reflections in dialogue with internship supervisors and thereby externalise tacit knowledge. This is illustrated by radiography students' placement within the SECI model ( Figure 2). Unlike radiography students, teacher students are excluded from some tacit knowledge, especially regarding the professional daily use of IT in municipal schools. This is illustrated (Figure 2) by the placement of teacher students outside the tacit dimensions of knowledge development.

Radiography students exert to combine knowledge through online seminars with peers, which is not the case in the teaching internship. Teacher students, however, do gain some knowledge from the experience of teaching. Such kinds of hands on 
skills are also offered to students in radiography. The knowledge gained can be a foundation for students' future practice embedded in knowing-in-action.

To the questions of knowledge development in workplace practice, radiography students' possibilities are limited by the hierarchy and production pressure illustrated by the arrow in Figure 2. Teacher students, on the other hand, may add tools for the use of the professionals to internalise in practice, as the case of making a grammar-book showed. However, these tools are presumably exclusively developed by students without the professionals' involvement. This might limit future adoption of the tools in the COP, and thereby internalisation in practice seems uncertain. The main results concerning the knowledge development of the radiography students (RS) and the teacher students (TS) are illustrated in Figure 2.

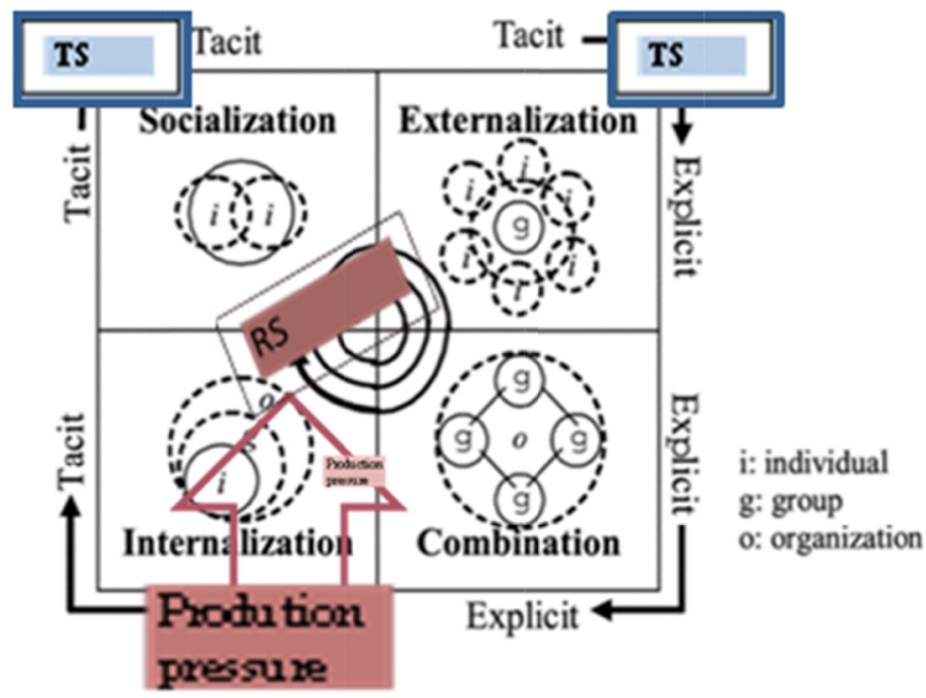

Figure 2. Students access to knowledge development and some conditions. Source: Adapted from Nonaka and Konno (1998, p. 43)

Students' access to knowledge development (Figure 2) and the professions' development are both influenced by the access to the professionals tacit and explicit knowledge and the conditions available for getting access to these kinds of knowledge.

The teaching students' process of knowledge development in internship seems weakened by the lack of access to tacit knowledge and lack of cooperative apprenticeship (illustrated by the TS-boxes in Figure 2, where TS are placed outside or only partly included as individuals), and the radiography students' process of knowledge development, by the conditions of hierarchy and production pressure (marked by the big arrow in Figure 2). 
Occasionally, online technology in both educations offers possibilities regarding connection to other students and supervisors across hospitals and municipal schools, but these connections are still geographically bounded. This may reduce participants' access to broader perspectives into practical problems. If students extended their participation in professional online networks nationally or internationally, they could assess, extend and combine their local knowledge and learn from other professionals (Hanson-Smith, 2013). The relationships of these kinds of online social networks are tenuous but may represent what Granovetter (1973) calls weak ties with the potential to facilitate and spread ideas beyond a hospital or a municipal school unit.

Finally, internalisation of students' gained knowledge calls for students as equal, respected participants in a real community of practice. This participation might be afforded by longer periods of internship and acknowledgement of students' ability to extend the existing knowledge in workplaces. However, there is a need for further research to evaluate such interventions.

\section{REFERENCES}

Akkerman, S. F., \& Bakker, A. (2011). Boundary crossing and boundary objects. Review of Educational Research, 81(2), 132-169.

Benner, P. (1984). From novice to expert. Excellence and power in clinical nursing practice. San Francisco, CA: Addison-Wesley Publishing Company.

Billett, S. (2001). Learning throughout working life: Interdependencies at work. Studies in Continuing Education, 23(1), 19-35.

Carter, M., \& Francis, R. (2001). Mentoring and beginning teachers' workplace learning. Asia-Pacific Journal of Teacher Education, 29(3), 249-262.

Collins, A., Brown, J. S., \& Newman, S. E. (1987). Cognitive apprenticeship: Teaching the craft of reading, writing and mathematics. Technical Report No. 403. Cambridge, MA: BBN Laboratories, Centre for the Study of Reading, University of Illinoisnick.

Dalton, J. (2004). "A" is for applied: what is applied learning? Fine Print, 1, 8-15.

Dau, S. (2013). When creating new learning spaces, the affordance is a key study aspect. Paper presented at the London International Conference on Education (LICE-2013), London, 4-6 November.

Dau, S., \& Nielsen, G. (2009). Praksis og Teori - vidensgrundlag, mangfoldighed og utydelighed København: Books on Demand.

Dau, S., \& Nielsen, G. (2011). Vidensgrundlaget i professionsuddannelserne - kognition som fundament eller forplumring? Gjallerhorn Tidsskrift for professionsuddannelser, 14, 70-80.

Davey, G., \& Fuller, A. (2010). Hybrid qualifications increasing the value of vocational education and training in the context of lifelong learning. England Country Report. Southampton Education School: University of Southampton.

Dreyfus, H., \& Dreyfus, S. (1991). Intuitiv ekspertise. Den bristede drøm om toenkende maskiner København: Munksgaard.

Eraut, M. (2007). Learning from other people in the workplace. Oxford Review of Education, 33(4), 403-422.

Garrison, R., \& Vaughan, H. (2008). Blended learning in higher education: Framework, principles and guidelines. San Francisco, CA: Jossey-Bass.

Granovetter, M. S. (1973). The strength of weak ties. American Journal of Sociology, 78(6), 13601380.

Guzman, G. (2009). What is practical knowledge? Journal of Knowledge Management, 13(4), 86-98. 
Hanson-Smith, E. (2013). Online communities of practice. The Encyclopedia of Applied Linguistics.

Harris, R., Willis, P., Simons, M., \& Collins, E. (2001). The relative contributions of institutional and workplace learning environments: An analysis of apprenticeship training. Journal of Vocational Education \& Training, 53(2), 263-278.

Harrison, L. (2006). "What is applied learning?" Exploring understandings of applied learning amongst beginning teachers. Paper presented at the Australian Association for Research in Education Conference, Adelaide.

Heggen, K. (1995). Sykehuset som 'klasserom' Praksisopplcering i professjonsutdanninger. Oslo: Oslo Universitetsforlag.

Illeris, K. (2013). Transformativ laering og identitet. Frederiksberg: Samfundslitteratur.

Jørgensen, C. H., \& Lindvig, K. (2011). Hybrid qualifications. Increasing the value of vocational education and training in the context of lifelong learning: Country report 2 Denmark. Views and experiences of stakeholders in relation to hybrid qualifications. European Commission.

Lave, J. (2011). Apprenticeship in critical ethnographic practice. University of Chicago, IL: Chicago Press.

Lave, J., \& Wenger, E. (1991). Situated learning. Legitimated peripheral participation. Cambridge: Cambridge University Press.

Mayes, T., \& de Freitas, S. (2004). Review of e-learning theories, frameworks and models. London: JISC e-learning models study report. The Joint Information Systems Committee.

Nielsen, K., \& Kvale, S. (1999). Mesterlære som aktuel læringsform. In K. Nielsen \& S. Kvale (Eds.), Mesterlcere laering som social praksis (pp. 11-32). København: Hans Reitzels Forlag.

Nonaka, I., \& Nishiguchi, T. (2001). Knowledge emergence: Social, technical, and evolutionary dimensions of knowledge creation. New York: Oxford University Press.

Nonaka, I., \& Takeuchi, H. (1995). The knowledge-creating company. New York, Oxford: Oxford University Press.

Nyvang, T., \& Dau, S. (2013). Læringsrum og vidensudvikling i professionsuddannelser. Tidsskriftet Laering og Medier (LOM), 6, 11.

Polanyi, M. (1966). The tacit dimension. New York: Doubleday Garden City.

Resnick, L. B. (1987). The 1987 presidential address: Learning in school and out. Educational Researcher, 16(9), 13-54.

Ricoeur, P. (1984). Time and narrative (Vol. 1, McLaughlin, K. \& Pellauer, D. Trans.). Chicago: University of Chicago Press.

Ricoeur, P. (1989). The conflict of interpretation. London: The Abalone Press.

Roth, W-M, Masciotra, D., \& Boyd, N. (1999). Becoming-in-the-classroom: A case study of teacher development through coteaching. Teaching and Teacher Education, 15, 771-784.

Ryberg, T., \& Dau, S. (2013). Sociale medier i klinisk praksis - nye læringslandskaber og muligheder. In S. Glasdam \& S. Hundborg (Eds.), Laring i og af klinisk praksis (pp. 195-216). København: Nyt Nordisk Forlag Arnold Busck.

Schön, D. A. (1983). The reflective practitioner: How professionals think in action. Aldershot: Basic Books Inc.

Schön, D. A. (1987). Educating the reflective practitioner. San Francisco, CA: Jossey-Bass Publishers.

\author{
Susanne Dau \\ Institute of Communication \\ Aalborg University, Denmark
}




\section{LEADERSHIP IN TIMES OF GLOBALISATION AND UNCERTAINTY}

\section{INTRODUCTION}

Contemporary work organisations around the world are lured by the same mantra repeating globalisation, globalisation, globalisation ... The word brings with it a compelling imperative for organisational attention and action in order for them to survive and prosper in a constantly changing global marketplace where earlier models for thought and practice are proclaimed as being outdated (Lane \& Down, 2010; Terrell \& Rosenbusch, 2012). The key to organisational success often spells Leadership, focusing on the leader often in grandiose, heroic and mythological terms (Alvesson, 2012). Organisational leadership has been of theoretical interest for the last century and research as well as management literature is vast. The question of what constitutes effective leadership has been a topic for research since the beginning of the 1900s (Van Wart, 2012). Long before that, it attracted philosophical attention (e.g., in Plato's The Republic) and practical implications in different organisations, such as the military and the church. The focus of leadership research started by targeting the characteristics of the leaders and eventually on leadership relationships between leaders and their employees in concrete work situations. Lately the research focus has changed direction towards the cultural aspects of effective leadership in times of globalisation (Northouse, 2013). Such a change of research focus and understanding of leadership as a phenomena leads to new questions that deserve to be addressed and scrutinised today.

This chapter is based on a study of the aspects that are rhetorically highlighted as important and desirable in contemporary research and how these connotations may differ from earlier research. The terms 'earlier' and 'contemporary' are not to be understood as fixed time categories, but rather as markers of change, which Foucault (1972) describes as discursive breaks, or discontinuities. Such breaks are not always clear cuts, but may appear as overlaps. This study has the present (contemporary) leadership discourse as its focal point. To be more specific, the study aims to analyse how organisational leadership in a globalised working life is discursively produced in contemporary research rhetoric as something different from earlier discourses. The expression 'earlier' may seem odd term since leadership has been discursively produced in various ways historically, but it may be useful as a term to differentiate the present from the past.

Rhetoric can be understood in different ways, for example as an attempt to persuade organisations of the logical, ethical and emotional necessities of adapting 


\section{G. SPARRHOFF}

to the demands of a global market place (Sigrell, 2001) or as an expression of a present organisational discourse highlighting certain things as urgent, desirable and normal features of the present time (Edwards et al., 2004). The latter example views rhetoric as something more exhaustive than 'merely' persuasive techniques. Instead, rhetoric is understood as an expression of discourse. Such discourse production not only reveals the normalised and taken for granted truths about the conditions for working life today, it also tells us something about how we perceive ourselves and our present time in general.

The theoretical assumptions rest on Foucault's (1972) notion of 'a history of the present' referring to "those particular truths which have come to be accepted (almost without question) as realities of and for the present era" (Jose, 1998, p. 3). A history of the present can therefore be understood as those narratives, or stories, of normalised truths that we tell about ourselves and our present time and place, that is, our understanding of ourselves and the world we live in. Such historicised stories may be referred to as (hi)stories and they are the results of the discursively produced truths that make up a certain discourse (Foucault, 1972). (Hi)stories can be 'read' in all sorts of discursive artefacts such as written or oral communication, articulated in art, music, dance etc. (Foucault, 1972). A discourse can be understood as a regime of knowledge and truth in which some things have come to be held as true, desirable and normal, which means that some things are possible to think, do and say whereas other things are not (ibid.). Research is not immune from such discourse production. Rather, it has a privileged power and knowledge position (Foucault, 1972) in the formulation of what leadership is and does in organisations.

\section{METHODOLOGICAL APPROACH}

The empirical data for this study consist of research literature, which is to be regarded as artefacts telling (hi)stories about how leadership is discursively produced today.

The selection of data took its starting point in the keywords leadership and leadership development, which resulted in a vast amount of articles. Since all artefacts tell discursively produced (hi)stories it is neither the quantity nor the type of research articles that is of interest for this study. The first articles were therefore selected randomly. The only criterion was that they should deal with organisational leadership and be published as recently as possible after the year 2000. The first articles told (hi)stories about leadership as something strongly connected to globalisation and change, which needed further exploration as it appeared to be a significant sign of the present leadership discourse. This resulted in a snowball selection of new key words such as globalisation, culture and change in combination with the earlier keywords, which in turn led to further reading of contemporary research literature (marked with an asterisk, ${ }^{*}$, in the reference list). All in all, the selection of documents ended up with 25 academic journal articles published between 2001-2013. The majority of the articles were published 2007 or later, with a peak in 2010. They were published in journals covering a wide range 
of academic fields such as Leadership, Management, Psychology, Human Resource Management, Sociology, Business and Education.

The analysis of the documents was accomplished in three steps. The first step focused on identifying the prominent keywords in order to categorise and establish the central themes in the (hi)stories about present leadership research. The second step focused on the argumentation and rhetoric by identifying explicit and implicit binary couples showing what aspects that were held as desirable versus undesirable. The third step contained a comparison between earlier leadership research and present research in terms of how present leadership is understood as something different from earlier leadership.

\section{Organisation of the Chapter}

To be able to identify discursive breaks and possible overlaps between the contemporary and earlier leadership research there is first a short review of the main characteristics of the evolvement of leadership research in terms of theories and approaches in the section Earlier leadership research (hi)stories. The section Leadership (hi)stories of the present presents the central themes of the present leadership discourse related to globalisation based on the document study. The section Leadership in globalised organisations analyses discursive brakes and overlaps between earlier and contemporary leadership discourses in order to understand how the present (hi)stories are different from past (hi)stories. The last section summarises the findings of the study.

\section{EARLIER LEADERSHIP RESEARCH (HI)STORIES}

In the early 1900 s leadership research showed an interest in identifying key characteristics of 'great leaders' and what made them different from non-leaders. Researchers came to focus on individual leader traits (Bass, 1990; Lord, DeVader \& Alliger, 1986; Stogdill, 1948). After finding a large number of characteristics, of which some may not be unique to leaders, the list has been narrowed down to five major traits, called the Big Five (Goldberg, 1990), that make up leader personality: neuroticism, extraversion, openness, agreeableness and conscientiousness. This line of research construe leadership in terms of the characteristics of the leader and how great leaders are as persons (Northouse, 2013).

In the 1950s, Katz developed a three-skill model based on technical skills, human skills, and conceptual skills (Katz, 1955). He suggested that particular leader skills varied depending on the organisational level in the management hierarchy. According to this theory, top management required less technical skills but more human and conceptual skills; middle management called for a high degree of all these skills; and supervisory management required a high degree of technical and human skills and less conceptual skills. The focus on leader skills produces a discourse of leaders in terms of what they know rather than what they are (Northouse, 2013). 


\section{G. SPARRHOFF}

Researching leader styles has been another theoretical approach where leader behaviours, in terms of activities and actions, have gained attention. Such studies, for instance Stogdill (1963), Bowers and Seashore (1966), Blake and Mouton (1985), have identified behaviours concerning tasks, relations, participation and change, and, in some cases, a mix between the task and/or the situation in combination with leader behaviour. The model "the leadership grid" developed by Blake and Mouton (1985) identifies two different leader concerns; concern for people and concern for results. Research on leader behaviour focuses on what leaders do rather than what they are.

The three approaches above all understand leadership in terms of the leader. In the late 1960s Hersey and Blanchard (1969), inspired by the style approach and the different leader concerns in the leadership grid, formed a model called Situational leadership (Blanchard et al., 1985). Instead of focusing on the leaders' being or doing, this approach highlights the situation and the relationship with other people as important contextual and relational aspects. This approach inspired other theories such as Contingency theory (Fiedler, 1964) aiming at matching the situation with the right leader style, Path-goal theory (House \& Mitchell, 1974) emphasising the relationship between the leader's style, the characteristics of the subordinates and the work setting, and Leader-Member exchange theory (Graen, \& Cashman, 1975) focusing on the interactions between the leader and the subordinates suggesting that leaders have different relationships with different subordinates.

An approach to leadership that has gained popularity in many contemporary organisations is Transformational leadership (Lowe \& Gardner, 2001). This approach has its roots in something called charismatic leadership, which was located within the style approach in the late 1970s. Transformational leadership also puts forward the assumption that the leader's behaviour is central to good (and bad) leadership. Good leaders should be concerned with improving the followers' performances and enabling them to reach their full potential. Good leaders are depicted as being inspirational role models, with strong internal values and ideals, who motivate their followers to act in ways that support the greater good rather than their own self-interests. Although the discourse of transformational leadership focuses on what leaders do (i.e., they inspire), it rather emphasises the leaders in terms of their personal characteristics in terms of what they are (i.e., they are inspirational).

\section{LEADERSHIP (HI)STORIES OF THE PRESENT}

Five themes emerged as especially significant features of the contemporary leadership discourse in the analysis of the studied documents: 1) Complexity and continuous change, 2) A new competitive landscape, 3) Cross-border relationships, 4) New expectations and careers, 5) Global leadership and culture, and 6) Globalisation and leader development. These themes will be developed below. 


\section{Complexity and Continuous Change}

Complexity and continuous change may be one of the strongest themes in the studied articles when it comes to describe globalisation and its challenges. Turbulence, high chaos, risk and uncertainty are pointed out as inherent features of globalisation (Arnett, 2002; Lane \& Down, 2010; Robinson \& Harvey, 2008; Terrell \& Rosenbusch, 2012; Wang, 2008). The challenge for leadership is described as to "enhance and maximize organisations' capacity in identifying, preparing for, preventing, resolving, and recovering from each crisis" (Wang, 2008, p. 427).

\section{A New Competitive Landscape}

Research on leadership and globalisation show great concern for a large number of challenges inherent in globalisation. Li and Tallman (Sheppard et al., 2013) even go so far as to warn that globalisation may threaten social, political, organisational and cultural health, well-being and security. Instability and insecurity of international finances and the global market place are reoccurring themes in contemporary research and are for example referred to in terms of "global financial crisis and organisational ethic mismanagement" (Sheppard et al., 2013) or "global financial melt-down" (Jacoby \& Meunier, 2010). Financial insecurity is closely linked to the new competitive landscape (Hitt \& Serpa, 2010), which according to them has changed the prerequisites for organisations due to a global economy, international business and politics as well as new technology (Hitt \& Serpa, 2010). Lane and Down (2010) argue that the competition in the global market place has led organisations to set short-time goals rather than long-term goals.

\section{Cross-border Relationships}

The challenges of the globalised world also concern cross-border relationships (Hitt \& Serpa, 2010; Lim \& Tsutsui, 2012; Sheppard et al., 2013). This is described as a complex network of relationships across national borders, with increasing multi-national and transnational connections and trade. The relationships between people take many different forms, for instance via physical meetings "IRL" (in real life) due to cheaper and faster communications, synchronic and asynchronic connections using new technology such as the Internet, so-called smart communication devices such as mobile phones, tablets etc. These new ways of connections and communication has led to increased interchange, interconnectedness, integration and thereby interdependence among organisations, countries and economies (Arnett, 2002; Hitt \& Serpa, 2010; Sheppard et al., 2013). The world seems to have become smaller due to more frequent connections between people and organisations from different parts of the world, but at the same time there are territorial, religious, political and cultural differences leading to many organisational challenges (Sheppard et al., 2013). Another aspect of this is that globalisation and localisation take place at the same time leading to a 


\section{G. SPARRHOFF}

psychological tension between global and local identities and understandings (Arnett, 2002).

\section{New Expectations and Careers}

The neoliberal globalised world with its focus on competition and demand for new knowledge, skills, attitudes and style has also led to new expectations and careers, on leaders and employees and as well as the young generation about to enter the labour market (Lim \& Tsutsui, 2012; Terrell \& Rosenbusch, 2012). Our contemporary globalised world is often labelled a knowledge society or learning society (Berglund, 2008). Such a society recognises the changing nature of knowledge and the need for continuous learning, so-called lifelong learning in order to learn new skills and develop a new identity as an entrepreneurial self (Alvesson, 2000; Fejes, 2008) sometimes referred to as a 'lifelong learner' (Berglund, 2008) or 'knowledge worker' (Hitt \& Serpa, 2010). Such identities also promise a completely new form of freedom where different forms of knowledge are always under social construction (Hermans \& Dimaggio, 2007). Carden and Callahan (2010) also refer to the construction of cultural-ideological identities in terms of self and collective identities and that there are conflicting roles and identities with blurred boundaries between work and non-work. From a leadership perspective there are thus many challenges when it comes to lead such a diversity of entrepreneurial selves with their individual global-local and work-non-work identities who do not fit the traditional notions of employees (Arnett, 2002; Carden $\&$ Callahan, 2010). The challenge is also to adapt to such a new identity as a leader and to face "the horrible realisation that in order to make it, you're going to have to change" (Carroll \& Levy, 2010, p. 218).

\section{Global Leadership and Culture}

Another important theme is that of global leadership and culture. One of the questions researchers have asked is whether global leadership is the same thing as traditional notions of leadership. The answer is mostly no (Robinson \& Harvey, 2008; Terrell \& Rosenbusch, 2012). In addition to more traditional leadership skills global leaders are argued to need- or develop - certain global skills and knowledge having to do with culture (Hitt \& Serpa, 2010; Terrell \& Rosenbusch, 2012). They also need a 'global mind-set' (Hitt \& Serpa, 2010; Sheppard et al., 2013; Terrell \& Rosenbusch, 2012). Javidan et al. (2006, p. 67) has identified an important aspect of global leadership.

Global leadership has been identified as a critical success factor for large multinational corporations. While there is much writing on the topic, most seems to be either general advice (i.e., being open minded and respectful of other cultures) or very specific information about a particular country based on a limited case study (do not show the soles of your shoes when seated as a guest in an Arab country). Both kinds of information are certainly useful, but 
limited from both theoretical and practical viewpoints on how to lead in a foreign country.

The research literature develops arguments about culture in many different ways using concepts such as multi-culture, diversity, pluralism, cultural sensitivity and cultural transferability to highlight cultural differences concerning for example identities, habits and traditions, corporate language, religion etcetera (Day, 2001; Dugan et al., 2011; Javidan et al., 2006; Kowske \& Anthony, 2007; Lim \& Tsutsui, 2011; Robinson \& Harvey, 2008; Rogerson-Revell, 2007; Van den Born \& Peltokorpi, 2010). Marga (2010) points out that it is an essential difference between learning about culture and understanding culture, and that understanding actually can be learned through reflecting on ones experiences. The concepts above mostly refer to national, ethnical, political or religious aspects. Alvesson (2012) also adds the social construction and labelling of gender as an important cultural and diversity aspect that influences the discursive production of leaders and leadership.

\section{Globalisation and Leader Development}

All the aspects (themes) of globalisation and leadership identified above are subject to leadership development since many leaders in contemporary organisations seem to lack the specific skills, knowledge, identity and global mind-set demanded in a globalised labour market (Carden \& Callahan, 2007; Carroll \& Levy, 2010; Day, 2001; Hitt \& Serpa, 2010; Kowske \& Anthony, 2007; Robinson \& Harvey, 2008; Terrell \& Rosenbusch, 2013). Contemporary research on global leadership often reflects a theoretical and philosophical understanding of culture and identity as aspects that are socially constructed and thus something that can be learned through leadership development. Day (2001) argues that there is a difference between leadership development and leader development. Leadership development refers to the strategic design work of building leadership capacities in an organisation, which contains how to attract, recruit and develop the leaders that are suitable and desired for the specific organisation from a strategic and long-term perspective. Garavan (2007) relates such strategic leadership development planning to that of strategic human resource and development (SHRD). Leader development on the other hand refers to the development of individual leaders (Day, 2001) and should follow the strategic leadership and leadership development plan for the organisation. Carroll and Levy (2010) suggest that leadership development should have a lifelong framework consisting of three steps: self-reading, self-authoring and self-revising.

\section{LEADERSHIP IN GLOBALISED ORGANISATIONS}

The literature review gives at hand that present leadership research is discursively construed around a number of explicit and implicit binary couples, for example: stability-change, the known-the unknown, mono-multi and local-global. Such 


\section{G. SPARRHOFF}

binaries suggest that not only the conditions for leadership have changed over time, but also the notions of what leadership is and does.

One sign of a discursive brake between earlier leadership and contemporary research is the argument by Terrell \& Rosenbusch (2012) and Hitt and Serpa (2010) that traditional leadership is not enough to deal with the challenges that are inherent in globalisation. They point out that globalised work organisations demand a deeper understanding of culture and diversity. Such a notion has come to be a normalised truth in contemporary working life, something that was not part of earlier discourses.

Another discursive brake concerns the stability-change binary where earlier research do not explicitly emphasise the changing character of the labour market or societal changes, but rather address leadership in terms of constant and stable traits, skills or styles. Leadership in the earliest studies is thus understood in terms of the leader. The desirable leader subject is discursively construed as someone who is, naturally or due to training, knowledgeable about the appropriate ways of handling the organisations and its employees. The focus is on leadership of the known and familiar. More recent research challenges this notion of stability and suggests that leadership is, to a large extent, about the unknown. Contemporary research on leadership is part of a wider discourse where change, complexity and competition are normalised features that organisations must adapt to and handle (Avolio et al., 2009). Such a discourse is characterised by narratives about risk, chaos and uncertainty (Arnett, 2002; Harvey, 2008; Lane \& Down, 2010; Robinson \& Wang, 2008; Terrell \& Rosenbusch, 2012).

The mono-multi binary can be seen in the earlier focus on the leader as a role model versus contemporary understandings of leadership as the management of diversity. This indicates a discursive brake between an earlier discourse of best practice and conformity where there is a best way of doing things in an organisation and the leader has the skills and knowledge to be a good role model (Lowe \& Gardner, 2001), and a contemporary discourse celebrating best fit focusing on organisational sensitivity towards a plurality of understandings and knowledge (Day, 2001; Dugan et al., 2011; Javidan et al., 2006; Kowske \& Anthony, 2007; Lim \& Tsutsui, 2011; Robinson \& Harvey, 2008; RogersonRevell, 2007; Van den Born \& Peltokorpi, 2010). The contemporary discourse shows a normalised ideal of working with leadership strategies that include diverse cultures. It also shows a normalised ideal for organisations to work with strategic leadership development to suit the ever-changing globalised workplace (Day, 2001; Garavan, 2007).

The main rhetorical argument for change in the contemporary leadership discourse is globalisation. Globalisation should accordingly lead to new ways of thinking about and doing leadership. Accordingly, complex societies and complex organisational conditions demand a view on leadership in terms of complex and emergent dynamics in organisations (Avolio et al., 2009). Globalisation together with the rapid speed of new inventions and new technology is referred to as a complexity that is unique in history (Hitt \& Serpa, 2010). The rhetoric in contemporary research implies that earlier leadership research and practice had a 
normalised understanding of leadership as something non-complex, or even simple, carried out in local organisations by leaders with local leadership identities whereas leadership today is about leadership in globalised organisations demanding a global identity and mind-set (Arnett, 2002). The present discourse suggests that the construction of desirable leadership is not to be understood in absolute and general terms since the conditions for leadership are continuously on the move. Leadership is rather to be understood as a contextualised and changing phenomenon in complex organisations (Arnett, 2002; Hermans \& Dimaggio, 2007). The localglobal binary is thus another sign of a discursive brake.

Competition is yet another feature that is construed as a significant sign of the present organisational discourse (Hitt \& Serpa, 2010; Lane \& Down, 2010). In earlier leadership research the notion of competition was not so visible even though it got more and more attention as corporations grew bigger and expanded internationally. When competition was mentioned in leadership literature it was something that mostly concerned big organisations in the private sector (Moqvist, 2005). It is still too early to distinguish whether there is a discursive brake or an overlap in the research discourse when it comes to the localisation of leadership. The main contributions to international leadership research focus on large national or multinational companies in the private sector in the western world (Northouse, 2013). Leadership is still conceptualised in terms of male leaders (Alvesson, 2012) in the private sector (Moqvist, 2005). Far less research has been committed to leadership in the public sector, which often is quite different due to the specific power relationship between political leadership, and so-called white-collar public leadership and administration (Moqvist, 2005). In the contemporary discourse competition is a normalised truth, both nationally and internationally, between and within organisations and between individuals.

\section{SUMMARY}

This study shows how the notion of leadership has changed over time. In this study contemporary leadership research has been analysed as a (hi)story of the present, i.e. a historicised narrative showing the normalised truth production about leadership. The present leadership narrative differs from earlier notions and understandings of leadership through a number of discursive breaks, which are illustrated by binary couples such as stability-change, the known-the unknown, mono-multi and local-global. In the present narrative leadership is intertwined with aspects such as globalisation, culture, diversity, identity formation and continuous change. Six themes have been identified as significant signs of the present discourse: 1) Complexity and continuous change, 2) A new competitive landscape, 3) Cross-border relationships, 4) New expectations and careers, 5) Global leadership and culture, and 6) Globalisation and leader development. To conclude, the present (hi)story of organisational leadership is a narrative of leadership as a complex phenomenon that demands something more than a grandiose, heroic and mythological leader (Alvesson, 2012) to manage the complexity of globalised organisations. It is a (hi)story that produces truths about a shrinking world where 


\section{G. SPARRHOFF}

globalisation not only takes place 'out there' in other countries, but at home in the own organisation at the same time. According to the present narrative globalisation demands a strategic leadership involving organisational self-awareness, selfreflection and a will to change. Maybe the most profound discursive break is that between the earlier trust in confident and 'natural' leaders who knew how to act and the contemporary urge for humble leaders who are able to lead their organisations in times of change and uncertainty.

\section{REFERENCES}

NOTE: References marked with an asterisk (*) are part of the empirical documents that this study is based on.

Alvesson, M. (2012). Critical leadership studies: The case for critical performativity. Human Relations, 65(3), 367-390.*

Alvesson, M. (2000). Social identity and the problem of loyalty in knowledge-intensive companies. Journal of Management Studies, 37(8), 1101-1123.*

Arnett, J. J. (2002). The psychology of globalization. American Psychologist, 57(10), 774-783.*

Avolio, B. J., Walumbwa, F. O., \& Weber, T. J. (2009). Leadership: Current theories, research, and future directions. Annual Review of Psychology, 60, 421-449.*

Bass, B. M. (1990). Bass and Stogdill's handbook of leadership: A survey of theory and research. New York: Free Press.

Berglund, G. (2008). On lifelong learning as stories of the present. Doctoral Dissertation, No 84. Umeå: Umeå University, Department of Education.*

Blake, R. R., \& Mouton, J. S. (1985). The managerial grid III. Houston, TX: Gulf Publishing Company.

Blanchard, K., Zigarmi, P., \& Zigarmi, D. (1985). Leadership and the one minute manager: Increasing effectiveness through situational leadership. New York: William Morrow.

Bowers, D. G., \& Seashore, S. E. (1966). Predicting organizational effectiveness with a four-factory theory of leadership. Administrative Science Quarterly, 11, 238-263.

Carden, L. L, \& Callahan, J. L. (2010). Creating leaders or loyalists? Conflicting identities in a leadership development programme. Human Resource Development International, 10(2), 169-186.*

Carroll, B., \& Levy, L. (2010). Leadership development as identity construction. Management Communication, 24(2), 211-231.*

Day, D. V. (2001). Leadership development: A review in context. Leadership Quarterly, 11(4), 581613.*

Dugan, J. P., Rossetti Morosini, A. M., \& Beazley, M. R. (2011). Cultural transferability of socially responsible leadership: Findings from the United States and Mexico. Journal of College Student Development, 52(4), 456-474.*

Edwards, R., Nicoll, K., Solomon, N., \& Usher, R. (2004). Rhetoric and educational discourse: Persuasive texts? London: Routledge Falmer.

Fejes, A. (2008). European citizens under construction: The Bologna process analysed from a governmental perspective. Educational Philosophy and Theory, 40(4), 515-530.*

Fiedler, F. E. (1964). A contingency model of leadership effectiveness. In L. Berkowitz (Ed.), Advances in experimental social psychology, (pp. 149-190). New York: Academic Press.

Foucault, M. (1972). The archaeology of knowledge. New York: Pantheon Books.

Garavan, T. N. (2007). A strategic perspective on human resource development. Advances in Developing Human Resources, 9(1), 11-30.*

Goldberg, L. R. (1990). An alternative "description of personality": The big-five factor structure. Journal of Personality and Social Psychology, 59, 1216-1229. 
Graen, G. B., \& Cashman, J. (1975). A role-making model of leadership in formal organizations: A developmental approach. In J. G. Hunt \& L. L. Larson (Eds.), Leadership frontiers (pp. 143-166). Kent, OH: Kent State University Press.

Hermans, H. J. M., \& Dimaggio, G. (2007). Self, identity, and globalization in times of uncertainty: A dialogical analysis. Review of General Psychology, 11(1), 31-61.*

Hersey, P., \& Blanchard, K. H. (1969). Life-cycle theory of leadership, Training and Development Journal, 23, 26-34.

Hitt, M. A., Haynes, K. T., \& Serpa, R. (2010). Strategic leadership for the $21^{\text {st }}$ century. Business Horizons, 53, 437-444.*

House, R. J., \& Mitchell, R. R. (1974). Path-goal theory of leadership. Journal of Contemporary Business, 3, 81-97.

Jacoby, W., \& Meunier, S. (2010). Europe and the management of globalization. Journal of Public Policy, 17(3), 299-317.*

Javidan, M., Dorfman, P. W., Sully de Luque, M., \& House, R. J. (2006). In the eye of the beholder: Cross cultural lessons in leadership from project GLOBE. Academy of Management Perspectives, 20(1), 67-90.*

Jose, J. (1998). Biopolitics of the subject: An introduction to the ideas of Michel Foucault. Darwin: Northern Territory University Press.

Katz, R. L. (1955). Skills of an effective administrator. Harward Business Review, 33(1), 33-42.

Kowske, B. J., \& Anthony, K. (2007). Towards defining leadership competence around the world: What mid-level managers need to know in twelve countries. Human Resource Development International, 10(1), 21-41*

Lane, D. A., \& Down, M. (2010). The art of managing for the future: Leadership of turbulence. Management Decision, 48(4), 512-527.*

Lim, A., \& Tsutsui, K. (2012). Globalization and commitment in corporate social responsibility: Crossnational analyses of institutional and political-economy effects. American Sociological Review, $77(1), 69-98 * *$

Lindqvist Grinde, J. (2008). Klassisk retorik för vår tid (Classical rhetoric for our time). Lund: Studentlitteratur.

Lord, R. G., DeVader, C. L., \& Alliger, G. M. (1986). A meta-analysis of the relation between personality traits and leadership perceptions: An application of validity generalization procedures. Journal of Applied Psychology, 71, 402-410.

Lowe, K. B., \& Gardner, W. L. (2001). Ten years of the leadership quarterly: Contributions and challenges for the future. Leadership Quarterly, 11(4), 459-514.

Marga, A. (2010). Globalization, multiculturalism and brain drain. Journal of Organisational Transformation and Social Change, 7(1), 105-115.*

Moqvist, M. (2005). Ledarskap $i$ vardagsarbetet: en studie av högre chefer $i$ statsförvaltningen (Leadership in everyday work: A study of top managers in public administration). Doctoral Dissertation, No 100. Linköping: Linköping University, Department of Behavioural Sciences.

Northouse, P. G. (2013). Leadership: Theory and practice (6 $6^{\text {th }}$ ed.). Los Angeles: Sage.

Robinson, D. A., \& Harvey, M. (2008). Global leadership in a culturally diverse world. Management Decision, 46(3), 466-480.*

Rogerson-Revell, (2007). Using English for international business: A European case study. Elsevier Science Direct: English for Specific Purposes, 26, 130-120.*

Sheppard, J-A., Sarros, J. C., \& Santor, J. C. (2013). Twenty-first century leadership: International imperatives. Management Decision, 51(2), 267-280.*

Sigrell, A. (2001). Att övertyga mellan raderna: en retorisk studie om underförståddheter $i$ modern politisk argumentation (To persuade in-between the lines: A rhetorical study on implications in political argumentation). Åstorp: Rhetor.

Stogdill, R. M. (1948). Personal factors associated with leadership: A survey of the literature. Journal of Psychology, 25, 35-71. 


\section{G. SPARRHOFF}

Stogdill, R. M. (1963). Manual for the leader behavior description questionnaire form XII. Columbus: Ohio State University, Bureau of Business research.

Terrell, R. S., \& Rosenbusch, K. (2012). How global leaders develop. Journal of Management Development, 32(10), 1056-1079.*

Van den Born, F., \& Peltokorpi, V. (2010). Language policies and communication in multinational companies. Journal of Business Communication, 47(2), 97-118. *

Van Wart, M. (2012). Leadership in public organizations: An introduction. New York: M.E. Sharpe.

Wang, J. (2008). Developing organizational learning capacity in crisis management. Advances in Developing Human Resources, 10(3), 425-445.*

Yukl, G. (2012). Leadership in organisations ( $8^{\text {th }}$ ed.). New York: Pearson.

Gun Sparrhoff

Department of Behavioural Sciences and Learning

Linköping University, Sweden 
PART 2

MESO LEVEL OF WORKING AND LEARNING 



\section{POLICE STUDENTS' VALUES OF COMPETENCE RELATED TO A PROFESSIONAL CAREER}

\section{INTRODUCTION}

The Swedish police training program is currently a traditional vocational education program. The program's overall aim is to develop competences that are relevant to one's future career. This study focuses on Swedish police students' values of competence related to a professional career.

The overall question in this study is whether and how the police students' values of competence related to a professional career change during the training program. In this study, competence is defined as: (1) specific knowledge, (2) practical skills and (3) reflexive knowledge. This definition is based partly on the different individual skills (psychomotor, cognitive, affective, personality and social factors) presented by Ellström (1992) and partly on the knowledge dimensions used in the questionnaire of the Recruitment, Education and Career in the Police project (RECPOL) and used in similar studies of various vocational education programs in Norway (Smeby, 2007). The definition of competence used in this study constitutes a summary of the abilities, knowledge, skills, and insights that police training aims for (Swedish National Police Academy, 2014).

From the early 2000s, various studies on the future of the police training program have been conducted in which the issue of an academisation of the education has been discussed. The latest investigation showed a strong consensus that the police training program should become a full higher education program (SOU, 2008, p. 39). After this investigation was presented, the issue of the police training program's academisation has been subject to political agendas several times but without getting any definitive solution. In a time of uncertainty about how the future of the police training program will be, we need knowledge about how students perceive the current training program and how we best can influence the debate about the future police training program.

The Swedish police training program is conducted at three different locations; two are located at universities (Umeå and Växjö) and the third is conducted at the Swedish National Police Academy. The current Swedish police training program includes four semesters of study and one semester of internship at a police department. The study is characterised by a high level of subject integration, where theory and practice are mixed. In semesters 2 and 3, the students carry out one week of field studies at a police department. Teaching is conducted by both "police teachers," i.e., professional police officers who work as teachers, and academic 


\section{T. BÄCK}

teachers who are subject representatives of various topics in the training program. Teaching is based on problem-based learning, combined with various forms of skill training (Swedish National Police Academy, 2014). Recruitment for the police training program takes place twice a year and includes a large number of applicants. When the selection is completed and the students begin the police training program, they are basically guaranteed a job at one of the police departments.

The study presented in this chapter is a continuation of a pilot study conducted with two different groups of police students, one group that was at the beginning of the training program and another that was at the end of the same program (Wolming \& Bäck, 2011). This continuing study is based on a questionnaire given to all Swedish police students who began the police training program during the spring semester of 2011 and finished the program in the fall semester of 2012.

The study is part of a larger European collaboration project; RECPOL, with is an ongoing collaboration between police training programs in Sweden and other European countries (Norway, Denmark, Belgium, Finland, Iceland, Scotland and Spain [Catalonia]). The RECPOL project's overall aim is to coordinate the collection of survey data on police training programs in different countries with different systems for police training programs, both academic and more traditional vocational training programs.

\section{RESEARCH ON THE TRANSITION FROM EDUCATION TO WORK}

Previous research shows that it is often a challenge to implement vocational training. It is not just a matter of communicating various competences as jobspecific theoretical knowledge and practical skills, but also a question of how to bridge the gap between theory and practice (Smeby, 2007). Concepts such as "extended learning" and "connective learning" emphasise the importance of a link between critical reflection and practical applications to develop these skills.

Jørgensen (2004) describes, from a historical perspective, how vocational education has developed and changed over the past 50 years. Previously, education and the acquisition of skills were linked with work and conducted within the workplace. Now, vocational education has been transferred into the higher educational system; at the same time, theoretical knowledge has become more important. Lindberg describes in his thesis the transition from medical education to working life as a doctor, as well as the gap between theoretical knowledge from training and practical professional skills that are in demand in working life, such as social skills and the ability to handle difficult situations in the workplace (Lindberg, 2012).

Discrepancies between higher education and working life have been attributed to, among other things, different rationalities. Knowledge is valued differently within the educational system and working life. In the educational system, theoretical knowledge is valued highly, while in working life, practical skills are more valuable (Jørgensen, 2004). To provide viable interactions based on these different rationalities, an institutional framework to mediate between them is 
needed. Jørgensen (2004) suggested that a modernised version of the dual system of vocational training may be the best to provide such a framework. Professional occupational areas are broad and difficult to grasp, and in constant and rapid change, which makes it difficult to predict what kind of competences will be required in future working life (Barnett, 2004).

As professional practice is largely unpredictable and characterised by unique problems and situations, it is not possible to fully prepare for professional work through higher education. Professional competence is about reflection, and professional work requires constant reflection, both in action and at work (Schön, 1983).

Results from one study show that students' expected learning outcomes, in terms of specific knowledge, practical skills, and reflexivity, were positive, in relation to the connections among respective knowledge dimensions at the end of their training program. This is not necessarily a criticism of education quality, but can also imply that the students developed a "wanting structure" and realised that they needed to continually develop new skills (Smeby, 2007).

Vocational training emphasises the promotion of knowledge and technical skills to satisfy the required skills for a profession. Colley et al. (2003) developed the concept of "vocational habitus" to explain a key aspect of students' experiences. Students find themselves included as they orientate themselves to a vocational habitus - a set of dispositions, both idealised and realised - and are informed of the guiding ideologies in the vocational culture (Colley et al., 2003). Nielsen (2009) suggests that there is a tendency towards egocentrism in the vocational education field, which means that education and the workplace consider themselves more valuable or more professionally qualified than the other environment. Nielsen also believes that we must begin to see the transfer of competence not as a threat that we must overcome, but as an opportunity to help us develop new ways of doing things, both in vocational education and the workplace (Nielsen, 2009). One way to better understand what influences the transfer of competence between education and working life can be studying how students' values of competence and job values are developed during education and at work.

Dæhlen (2005) showed that job values change during training, but that these changes are small and do not seem to be related to gender or type of education. Differences in job values between men and women, and especially between students in different programs, were maintained during the study, suggesting that the choice of education is the first step in realising work preferences. Based on previous research about the transition from education to work, it is therefore of interest to deepen the understanding of police research, particularly on police training and the professional competence of police. The first step is to investigate how the valuations of different competences change during the police training program, and after that, to study this in the transition between education and working life. 


\section{RESEARCH ON POLICE EDUCATION AND VALUES OF COMPETENCE}

Previous research on police has often been about the police profession and different policing methods (Weisburd \& Braga, 2006; Reiner, 2010; Valland, 2011). Police research has also touched upon the socialisation of police and their professional culture which, according to many, is special to the police (Finstad, 2000; Granér, 2004; Lauritz, 2009; Loftus, 2009).

Paterson (2011) reviews English-language literature describing developments in police training and education to find areas where higher education can add value to police training and development. According to Roberg and Bonn (2004), there has been a long-standing debate in the US about whether higher education for police officers is desirable or even necessary. Today, with the ever growing complexity of police work, a rapidly changing social landscape and rapid technological developments have renewed the debate about higher education for police officers. Jaschke (2010) describes similar developments in the EU, where problem-oriented and intelligence-led policing is built on the latest developments in society. Risk assessment and risk management have become increasingly important parts of police work. Although research has shown the value of higher education, little empirical research has been done on the impact of higher education on police behaviour and performance (Feltes, 2002; Jaschke, 2010).

From a Swedish and Nordic perspective, there have been few studies dealing with police training, competence, norms, job-values and social background. Bäck (2010) describes the discrepancy between the competence that students felt they got through the police training program and the competence demanded in the profession. This may be due to the problems that are usually found in the transition between education and work. One reason why there are difficulties with this transition is that there seem to be strong professional norms. Such norms are defined by police officers in the field, and describe the competences and skills they believe are needed in the profession. These norms also seem to permeate education and influence students early in their training programs. This, in turn, results in police students who tend to focus more on the competence and skills that these norms dictate than those aiming to promote and encourage change and professional development (Karp \& Stenmark, 2011).

Sundström and Wolming (2013) have studied police students' job values in relation to gender and educational background. The results show that the students estimated altruistic values were higher than their intrinsic and extrinsic values, and that female students valued altruistic and intrinsic job values as being more important than male students did. One of their conclusions was that future studies should examine whether police students' job values change during education and in their transition to work.

\section{THEORETICAL FRAMEWORK}

Competence is a broad concept that has been discussed and defined by a number of researchers (Anderson \& Krathwohl, 2001; Ellström, 1992). When interpreting the 
concept of competence, it is useful to distinguish between different aspects. Ellström (1992) presents a definition of competence based on a number of conditions. Competence is about the relationship between the individual and work or a specific task. Ellström (1992) further describes how skills can be understood in terms of different individual skills (e.g., psychomotor, cognitive, affective, personality and social factors) (Ellström, 1992). In this study these individual skills are defined as specific knowledge, skills, and reflexivity (Smeby, 2007).

A fundamental characteristic of most professions is that they combine discipline-based knowledge and concepts with practical knowledge and experience (Eraut, 1994). This corresponds to the classical distinction between "knowing that" and "knowing how" (Ryle, 2009). In this study, the terms "specific knowledge" and "practical skills" are used to distinguish between these two aspects. Schön (1983) introduced the concept of reflection-in-action, which he claimed was needed to mediate between theory and practice. He expressed the value of reflection in the development from knowing-in-action to knowledge-in-action. In this study, reflexive knowledge is the third dimension of competence.

\section{PURPOSE}

The overall aim of the study presented in this chapter is to investigate whether and how the police students' values of competence change during the police training program. The more specific questions are:

- How do police students at the beginning and end of a police training program value different forms of competence in the program, in relation to their future career?

- Do these values differ according to gender and place of study?

\section{METHODS}

In this section, the participants, study design, instruments, and analysis are described.

\section{Participants}

The participants in this study were all police students at training locations in Sweden, who began their training program during the spring semester of 2011 (T1) and finished the fourth semester of their training program in the fall semester of 2012 (T4). There were 363 students who began the training program (T1). Of these, 350 students answered the questionnaire, which meant a loss of 3.6 percent. The students at the end of term 4 (T4) numbered a total of 360 . Of these, 320 students answered the questionnaire, which meant an overall loss of 11.1 percent. The loss between $\mathrm{T} 1(\mathrm{~N}=350)$ and $\mathrm{T} 4(\mathrm{~N}=320)$, may be due to a number of factors. For example, the students may have taken a study break, 


\section{T. BÄCK}

dropped out of their studies, or failed to respond to all of the questionnaire's subquestions.

The proportion of men was 62 percent, and the proportion of women was 38 percent. The average age was 26.9 years at the first measurement. Additional background variables will be presented in the Results section.

\section{Design and Instruments}

To investigate the possible changes in the police students' values of competence, a follow-up design with two assessments was used. The choice of design was motivated by the fact that the two student groups consisted of the same individuals, but at different stages of the training program (the beginning and the end of the training, respectively).

The issues that the police students were asked about are part of the European police research comparative study, RECPOL (Recruitment, Education and Careers in the Police - A European Longitudinal Study). The RECPOL comparative study includes countries such as Sweden, Norway, Denmark, Belgium, Finland, Iceland, Scotland and Spain (Catalonia). The questionnaire that the police students answered, is part of a larger study based on a Norwegian study. The Norwegian survey was developed by the Centre for the Study of Professions, Oslo University College, to study vocational education programs of various kinds and is part of the so-called Stud-Data project (Smeby, 2007). In addition to questions about campus, age, and gender, the police students' values of competence in relation to future career are focused upon in this study. Concretely, this means that the police students estimated the relevance of different competence dimensions in relation to their future professional career.

In the present study, the competence dimensions are based on the dimensions applied by Ellström (1992), the knowledge dimensions used in different Stud-Data projects, and those from Smeby (2007). These dimensions of competence are: specific knowledge (Items 1a-1b), practical skills (Items 2a2c), and reflexive knowledge (Items 3a-3d). Table 1 shows all items for each competence dimension. The relevance of the competence dimensions in relation to future careers was estimated on a 5 -point scale $(1=$ not at all, $5=$ very much).

The competence dimensions were used in an exploratory factor analysis, and the estimation showed a good agreement between competence dimensions and the items listed in Table 1. The internal consistency (Cronbach's alpha) for each competence dimension was also examined: specific knowledge (T1: $\alpha=.43, \mathrm{~T} 4: \alpha$ $=.70)$, practical skills (T1: $\alpha=.59$, T4: $\alpha=.67)$, and reflexive knowledge (T1: $\alpha=$ $.77, \mathrm{~T} 4: \alpha=.86)$. 
Table 1. Items related to competence dimensions

\begin{tabular}{lll}
\hline Competence dimension & Item & \\
\hline Specific knowledge & la & Occupation-specific knowledge \\
& $1 \mathrm{~b}$ & Understanding of rules and regulations \\
Practical skills & $2 \mathrm{a}$ & Ability to work independently \\
& $2 \mathrm{~b}$ & Ability to take the initiative \\
& $2 \mathrm{c}$ & Ability to lead others \\
Reflexive knowledge & $3 \mathrm{a}$ & Tolerance, ability to appreciate different points of \\
& & view \\
& $3 \mathrm{~b}$ & Ability to make ethical judgement \\
& $3 \mathrm{c}$ & Ability to empathise with the situation of others \\
& $3 \mathrm{~d}$ & Values and attitudes \\
\hline
\end{tabular}

Analysis

The calculations performed included the mean, standard deviation, t-test, and exploratory factor analysis. Several methods exist to create composite variables. In this study, the value of each item was summed and divided by the number of items in each dimension, resulting in an average value for each competence dimension. In the present study, the analysis groups (T1 and T4) are not considered to be random but as two separate groups from the same cohort. All of the analyses in this study were conducted with IBM SPSS Statistics 22.

\section{RESULTS}

In this section, the mean, standard deviation, and differences between $\mathrm{T} 1$ and T4 will be presented. The results will also be presented for gender and place of study.

\section{Values of Competence and Future Careers}

The results show a generally high level of estimation and measurement of how important each competence dimension/object was for the student's future career at both T1 and T4. All of the mean values are above the scale's midpoint. For each item, the mean values at $\mathrm{T} 4$ were reduced overall compared to $\mathrm{T} 1$. In the material, there is a significant difference between the estimated values at T1 compared to T4, except for Items $1 \mathrm{a}$ and $2 \mathrm{~b}$. Table 2 shows the means, standard deviations, and significance for Items $1 \mathrm{a}-3 \mathrm{~d}$.

A breakdown by gender indicates some differences in how the men and women valued each competence dimension. Table 3 presents the mean values and differences in competence dimensions by gender. 
Table 2. Mean and standard deviation for items $1 a-3 d$

\begin{tabular}{|c|c|c|c|c|c|c|c|}
\hline \multirow[b]{2}{*}{ Item } & & \multicolumn{2}{|c|}{$T 1$} & \multicolumn{2}{|c|}{ T4 } & \multirow[b]{2}{*}{ Diff. } & \multirow[b]{2}{*}{$P$-value } \\
\hline & & $M$ & $S D$ & $M$ & $S D$ & & \\
\hline & Specific knowledge & & & & & & \\
\hline 1a & $\begin{array}{l}\text { Occupation-specific } \\
\text { knowledge }\end{array}$ & 4.38 & .80 & 4.33 & .91 & -0.05 & .446 \\
\hline $1 b$ & $\begin{array}{l}\text { Understanding of rules and } \\
\text { regulations }\end{array}$ & 4.54 & .63 & 4.34 & .84 & -0.20 & .000 \\
\hline $2 \mathrm{a}$ & $\begin{array}{l}\text { Practical skills } \\
\text { Ability to work } \\
\text { independently }\end{array}$ & 4.05 & .83 & 3.79 & .92 & -0.26 & .000 \\
\hline $2 b$ & Ability to take the initiative & 4.53 & .61 & 4.45 & .80 & -0.08 & .148 \\
\hline $2 \mathrm{c}$ & Ability to lead others & 3.97 & .83 & 3.66 & .87 & -0.31 & .000 \\
\hline & Reflexive knowledge & & & & & & \\
\hline $3 a$ & $\begin{array}{l}\text { Tolerance, ability to } \\
\text { appreciate different points of } \\
\text { view }\end{array}$ & 4.62 & .59 & 4.18 & .85 & -0.44 & .000 \\
\hline $3 b$ & $\begin{array}{l}\text { Ability to make ethical } \\
\text { judgement }\end{array}$ & 4.62 & .57 & 4.11 & .89 & -0.51 & .000 \\
\hline $3 \mathrm{c}$ & $\begin{array}{l}\text { Ability to empathise with the } \\
\text { situation of others }\end{array}$ & 4.69 & .53 & 4.26 & .85 & -0.43 & .000 \\
\hline $3 d$ & Values and attitudes & 4.41 & .67 & 4.12 & .85 & -0.29 & .000 \\
\hline
\end{tabular}

$p=<0.05$

Table 3. Mean values and differences in competence dimensions by gender

\begin{tabular}{llcccc}
\hline Gender & Competence dimensions & T1 & T4 & Diff. & P-value \\
\hline Male & & & & & \\
& Specific knowledge & 4.47 & 4.35 & -0.12 & .075 \\
& Practical skills & 4.14 & 3.99 & -0.15 & .030 \\
& Reflexive knowledge & 4.52 & 4.17 & -0.35 & .000 \\
& & & & & \\
Female & Specific knowledge & 4.46 & 4.33 & -0.13 & .113 \\
& Practical skills & 4.26 & 3.93 & -0.33 & .000 \\
& Reflexive knowledge & 4.67 & 4.15 & -0.37 & .000 \\
\hline
\end{tabular}

$p=<0.05$

At the end of the training program, the men and women valued the importance of the different dimensions relatively equally. If we look at the difference between the men and women for each competence dimension, no differences are found in the mean values for the "specific knowledge" dimension. The decrease is the same for both sexes. Differences are found, however, for the dimensions of practical 
skills and reflective knowledge. The resulting image shows that the reduction was greater for women than for men.

Since the police training program was conducted at three different locations in Sweden, there is an interest in whether the place of study could explain the overall picture of the results concerning competence-dimensional estimates. Table 4 shows the averages and differences in competence dimensions divided by place of study.

Table 4. Mean values and differences in competence dimensions divided on place of study

\begin{tabular}{llcccc}
\hline Place of study & Competence dimensions & T1 & T4 & Diff. & P-value \\
\hline Solna & & & & & \\
& Specific knowledge & 4.49 & 4.40 & -0.09 & .241 \\
& Practical skills & 4.20 & 4.03 & -0.17 & .011 \\
Växjö & Reflexive knowledge & 4.58 & 4.22 & -0.36 & .000 \\
& & & & & \\
& Specific knowledge & 4.39 & 4.28 & -0.11 & .388 \\
& Practical skills & 4.17 & 3.94 & -0.23 & .068 \\
Umeå & Reflexive knowledge & 4.59 & 4.18 & -0.41 & .001 \\
& & & & & \\
& Specific knowledge & 4.47 & 4.24 & -0.23 & .064 \\
& Practical skills & 4.18 & 3.87 & -0.31 & .002 \\
& Reflexive knowledge & 4.59 & 4.05 & -0.54 & .000 \\
\hline$p=<0.05$ & & & & &
\end{tabular}

The results show some differences between all three places of study regarding how their students estimated the importance of each competence dimension. For all three dimensions, the reduction was greatest in Umeå, while it was lowest in Solna. It is interesting that practical skills are valued lower than specific and reflexive knowledge at all of the places of study. At all three places of study, reflexive knowledge was valued highest at the start of the training program, and specific knowledge was valued highest at the end of the training program.

\section{Summary of Results}

The students' estimates of the various dimensions of competence were generally high at both T1 and T4. All of the estimates are above the scale's centre value. The overall result was that there is a general reduction in police students' assessment of the various forms of competence, from the beginning compared to the end of the training program.

When the comparison between $\mathrm{T} 1$ and $\mathrm{T} 4$ is divided by gender, the results show that there were no differences between the men and women for specific knowledge. For the dimensions of practical skills and reflective knowledge, the reduction was greater for the women compared with the men. 


\section{T. BÄCK}

When the comparison between T1 and T4 is divided by place of study, it turns out that the highest difference between $\mathrm{T} 1$ and $\mathrm{T} 4$ for all competence dimensions can be linked to Umeå. The practical skills dimension was valued lowest at all places of study, both at the beginning and end of the training program. At all three places of study, reflexive knowledge was valued highest at the start of the training program, and specific knowledge was valued highest at the end of the training program.

\section{DISCUSSION}

One explanation why the students' values for the studied competence dimensions were lower at the end of the training program might be, aside from several exceptions, because they will be offered employment as police officers. This, in turn, depends on there being a need for professional police officers, since the Swedish government has had a goal to increase the number of professional police officers over a number of years. Therefore, the present working life and professional culture of police officers are more interesting than the competences needed to develop the profession and the professional role.

Another explanation for this result may be that students in the latter part of the training program have a significantly larger and more relevant understanding of how each knowledge dimension is actually related to their future professional career. According to Karp and Stenmark (2011), police students are subjected to strong professional norms that are defined by professional police officers, and these norms may have an impact on the students at the beginning of their education. The students may have also realised the need to develop new skills or for "wanting structure" (Smeby, 2007).

A further explanation may be that the students in the latter part of the training program had experience with working life, in the forms of field studies and meetings with professional police officers. Bäck (2010) argue that there is a discrepancy between the image of the profession, as conveyed in the police training program, and the image they encounter in professional practice. This could mean that the students get an idea of the profession during the field studies that also affects how they value the competences conveyed in the training program.

The results from this study show a relatively large conformity with previous research regarding the relationship between education and working life (Jørgensen, 2004; Barnett, 2004). The reflexive dimension of knowledge (Schön, 1983) was highly valued by students, especially at the beginning of training. This is also consistent with the guidelines of the Swedish National Police Academy (2014).

The differences that emerge when comparing women and men are somewhat difficult to interpret. One explanation is that the police profession is traditionally male-dominated, and practical skills are highly valued. Women seeking maledominated professions that are traditionally considered to be practical can attribute too great of a weight to practical skills. This may indicate that men and women do not apply and begin the police training program with the same ideas about 
education and the police profession. Also, this result may be due to the influence of the strong professional norms that Karp and Stenmark (2011) described in their study. The valuation of the knowledge dimensions by place of study shows some interesting results. For all dimensions of knowledge, the difference between T1 and T4 is lower in Solna compared to the other study locations. It is difficult to speculate about any explanation for this result; further research is needed to show how the training programs differ.

The study results have generated some knowledge and understanding related to police training and the police profession. In light of the investigations (e.g., SOU, 2008:39) conducted on the future of police training, in which a large consensus exists that the Swedish police training program should become a full college education, it is important to continue to examine the interface between education and the profession according to Sundström and Wolming (2013). In the present study, only the students' individual values regarding different knowledge dimensions were investigated. It would be desirable to find external and objective measures of students' actual knowledge. This would create opportunities to relate to individual valuations, students' actual competence in these areas, and the real competence that the police profession requires, thereby creating the conditions for a future police training program, where the training objectives and performance are more consistent with the future police profession's competence requirements.

There is currently uncertainty over whether the Swedish police training program should be transformed into formal higher education or remain as traditional vocational training. If the Swedish police training program were changed to formal higher education, it would be an interesting and exciting development in many ways, not least from an educational perspective. What does it mean for education to become academically compared to the current mission training? For this reason, it is of interest to study education/training programs before and after any such change. In future research, it will therefore be of interest to study whether and how the police students' values and competence change during the police training program, both in different educational contexts and in the transition to the police profession. The quantitative data presented in this study need to be complemented by qualitative data, in order to better show the changes in students' valuation of competence.

\section{REFERENCES}

Anderson, W., \& Krathwohl, D. R. (2001). A taxonomy for learning, teaching and assessing. A revision of Bloom's taxonomy of educational objectives. New York: Addison Wesley Longman.

Bäck, T. (2010). Från student till yrkesverksam polis - Mental träning i polisutbildningen och yrkeslivet [From student to professional police officer - Mental preparation training in Police Academy and profession]. (Licentiate dissertation). Umeå: Department of Education, Umeå University.

Barnett, R. (2004). Learning for an unknown future. Higher Education Research \& Development, 23(3), 247-260. 


\section{T. BÄCK}

Colley, H., James, D., Diment, K., \& Tedder, M. (2003). Learning as becoming in vocational education and training: Class, gender and the role of vocational habitus. Journal of Vocational Education and Training, 55(4), 471-496.

Dæhlen, M. (2005). Change in job values during education. Journal of Education and Work, 18(4), $385-400$.

Ellström, P. (1992). Kompetens, utbildning och lärande $i$ arbetslivet: Problem, begrepp och teoretiska perspektiv. Stockholm: Publica.

Eraut, M. (1994). Developing professional knowledge and competence. London: Falmer

Feltes, T. (2002). Community-oriented policing in Germany - Training and education. Policing - An International Journal of Police Strategies and Management, 25(1), 48-59.

Finstad, L. (2000). Politiblikket. Oslo: Pax Forlag.

Granér, R. (2004). Patrullerande polisers yrkeskultur. Doctoral Dissertation. Lund: School of Social Work. Lund University

Jashke, H. (2010). Knowledge-led policing and security. Policing: A Journal of Policy and Practice, $4(3), 302-309$.

Jørgensen, C. H. (2004). Connecting work and education: Should learning be useful, correct or meaningful? Journal of Workplace Learning, 16(8), 455-465.

Karp, S., \& Stenmark, H. (2011). Learning to be a police officer. Tradition and change in the training and professional lives of police officers. Police Practice and Research, 12(1), 4-15.

Lauritz, L.-E. (2009). Spirande polisidentiteter. En studie av polisstudenters och nya polisers professionella identitet [Police identities. A study of student police officers and new police officers' professional identity]. Doctoral Dissertation. Umeå: Umeå School of Business. Umeå University.

Lindberg, O. (2012). Let me through, I'm a doctor: Professional socialization in the transition from education to work. Doctoral Dissertation. Umeå: Department of Education, Umeå University.

Loftus, B. (2009). Police culture in a changing world. Oxford: Oxford University Press.

Nielsen, K. (2009). A collaborative perspective on learning transfer. Journal of Workplace Learning, 21(1), 58-70.

Paterson, C. (2011). Adding value? A review of the international literature on the role of higher education in police training and education. Police Practice and Research, 12(4), 286-297.

Polishögskolan (2014). Utbildningsplan för polisprogrammet [Syllabus for the police Training Program]. Stockholm: Swedish National Police Academy.

Reiner, R. (2010). The politics of the police. Oxford; New York: Oxford University Press.

Roberg, R., \& Bonn, S. (2004). Higher education and policing: Where are we now? Policing - An International Journal of Police Strategies and Management, 27(4), 469-486.

Ryle, G. (2009). The concept of mind. New York: Routledge.

Schön, D. (1983). The reflective practitioner. How professionals think in action. New York: Basic Books.

Smeby, J. C. (2007). Connecting to professional knowledge. Studies in Higher Education, 32(2), 207224.

SOU 2008:39. Framtidens polis [The future police]. Stockholm: Fritze.

Sundström, A., \& Wolming, S. (2014). Swedish student police officers' job values and relationships with gender and educational background. Police Practice and Research, 15(1), 35-47.

Valland, T. (2011). Nordisk politiforskning 2004-2009. En kommentert oversikt. PHS Forskning, No. 3. Oslo: Politihøgskolen.

Weisburd, D., \& Braga, A. (2006). Police innovation and crime prevention: Lessons learned from police research over the past 20 years. Cambridge: Cambridge University Press.

Wolming, S., \& Bäck, T. (2011). Polisstudenters kunskapssyn i relation till det framtida yrkeslivet [Police students view of knowledge in relation to future professional careers]. In L.-E. Lauritz \& M. Ghazinour (Eds.), Nordisk polisforskning (pp. 3-14). Polisutbildningens Skriftserie, nr 1. Umeå: Umeå universitet. 
POLICE STUDENTS' VALUES OF COMPETENCE

Thomas Bäck

Department of Education

Umeå University, Sweden 



\section{POLICE LEADERSHIP PRACTICE IN TIMES OF UNCERTAINTY AND ORGANISATIONAL TURMOIL}

\section{INTRODUCTION}

Resonating on the themes of globalisation, change and uncertainty, the following chapter offers a critical discussion regarding the role of leadership in occupational and organisational ambitions of renewal. An often espoused image of leaders in times of change is that of a guide showing the way for a work-group or organisation on a journey towards the desired future state of being (cf. Gill, 2002). Ironically, leadership of (and in) change in this way often tends to be described as something static and durable in an otherwise transforming environment. From this perspective, leaders are often conceptualised as change agents betrothed in the development of visions of the future that are operationalised into strategies aimed to bring visions to reality (Hooper \& Potter, 2000). As indicated by current research on leadership based on interpretative frameworks (cf. Crevani, Lindgren, $\&$ Packendorff, 2010), images such as these are unfortunate, as they tend to tie leadership to individual 'heroic' leaders with certain formal or informal mandates and thereby obscure several distinguishing characteristics of leadership in times of change and uncertainty.

The present chapter aims to outline a practice theory of leadership based on Schatzki (2001b, 2005). The chapter builds on a study of police leaders and police policy documents (Haake, Rantatalo, \& Lindberg, forthcoming), and in the following, we develop and explain the theoretical underpinning of the practice theory analysis of leadership. We argue that practice theory has merits in the study of leadership, as it allows an adoption of what can be termed a post-heroic view of leadership in which leading is less a question of who leads than what leads in a given situation. Our study takes this as a starting point as we analyse expectations on police leaders. In detail, we use interview data and an analysis of policy documents to analyse leadership in terms of expectations. This entails an attempt to highlight some important facets of the 'nitty-gritty details' of leadership routine and practice (see also Bryman, 2004; Chia \& Holt, 2006; Chia, 2004). In other words, our study follows research that focuses on the 'mundane' (Alvesson \& Sveningsson, 2003) work and expectations of leaders in everyday practice.

With examples drawn from a current case study of Swedish police leadership, the chapter demonstrates the possibility of focusing on leadership in terms of performances (Butler, 1993) taking place within different nexuses of doings and 


\section{O. LINDBERG ET AL.}

sayings (practice). With this aim, the chapter's contribution can be located in the formulation of a framework for research that holds the potential to forward discussions and contribute to knowledge development on the issue of leadership practice without resorting to traditional pitfalls of a heroic view on leadership.

\section{THE MERITS OF A PRACTICE THEORY \\ FRAMEWORK FOR LEADERSHIP RESEARCH}

In recent years, practice theory has been presented as a viable solution to a number of resilient and problematic dualisms of social theory, such as mind-matter and actor-structure (Sandberg \& Tsoukas, 2011; Schatzki, 2001a). In Schatzki's theory, a practice is defined as an organised, open-ended, spatial-temporal manifold of actions (e.g., cooking, farming, policing, and, of course, leading). Schatzki (2005) argues that practice theories are 'site ontologies', taking as their starting point neither individual nor structure but rather action. We should, according to Schatzki, not view an organisation as an array of individuals or as super-individual structures without room for agency.

Instead, the key to understanding 'the practice turn' in contemporary theory is to realise that it is actions rather than people that are organised. Actions are, in Schatzki's theory, primarily organised by understandings, rules and teleoaffectivity. 'Understandings' concern humans' past experiences with how to do things, such as understanding how to bake a cake or use a word processor. 'Rules' concern both explicit rules and laws, 'rules of thumb' and implicit rules of how things should be done. However, Schatzki (e.g., 2001b) devotes most of his explanation of understanding human action to teleoaffectivity. Teleo signifies that actions are goal-oriented; actions are undertaken to accomplish something (even though we often fail to accomplish what we intended) and are thus guided by hopes, beliefs and expectations. Affective, on the other hand, signifies that actions also originate from emotions, moods and, most importantly, what matters to humans. The degree of affection also determines importance to humans and how humans have invested in the carrying out of an action. Hence, Schatzki argues that people do what makes sense to them to do; it is not always what we would recognise as a rational act, but rather, it is dependent on specific goals for the action as well as present affection. This is what Schatzki calls practical intelligibility.

In the present chapter, we conceptualise leadership as a 'site'. This site is an analytical focus on specific performances concerning leading in an organisation. Lindberg (2012; 2013) as well as Lindberg and Rantatalo (2015) developed an analysis of interview statements based on the concept of teleoaffective structure in Schatzki's practice theory. Teleoaffective structure is described by Schatzki (2001) as:

... a range of acceptable or correct ends, acceptable or correct tasks to carry out for these ends, acceptable or correct beliefs (etc.) given which specific tasks are carried out for the sake of these ends, and even acceptable or correct emotion out of which to do so. [...] So practices establish social order, first, 
because they help mold the practical intelligibility that governs their practitioners' actions and thereby help determine which arrangements people bring about. (Schatzki, 2001b, pp. 53-54)

However, future actions also shape and reshape this structure. In this way, teleoaffective structure is, as a construct, reminiscent of performativity and citationality in, for instance, the works of Judith Butler (e.g., 1993). To operationalise the concept of teleoaffective structure, our empirical study focuses on the analysis of interviews and documents on espoused leadership performances. A leadership performance is defined as any action thought to be part of leadership, i.e., actions that are signified as belonging to the performance of leadership in the organisation. Bringing teleoaffectivity into the analysis, we also analyse the espoused normative dimension of these performances. Leadership performances are, in other words, described as good (acceptable, correct, desirable) or bad (unwanted, incorrect, undesirable) or as any point on a scale between these two.

The teleoaffective structure of leadership is hence investigated through the normative value that is given to certain leadership performances. We use the term expectations to map the teleoaffective structure governing leadership performance, constructed both around statements that positively (do like this) as well as negatively (do not do like this) point out leadership performance. Expectations on leadership performances are expressed in various forms: formally (as in policy), informally (as during a conversation with a co-worker), directly (as in orders and directives) or indirectly (as in consequences for measures taken in a given situation). Expectations can also be self-driven and self-perceived. In the 'fluidity' of leadership practice (Weick, 1993), demands, wishes and self-evaluations are all a part of teleoaffective structure in which leaders (and others that perform leadership) act and are acted upon.

An important point in focussing leadership performances is that they are not limited to the behaviour of leaders. Leadership research has, particularly within police leadership research, to a great extent been involved with the effectiveness of certain leadership traits and behaviours. As a site ontology, practice theory gives room for other performances and other arrangements (such as material arrangements or other people) performing leadership.

\section{LEADERSHIP IN UNCERTAIN TIMES AND CHANGE}

As an empirical context suitable for the study of leadership in change, it can be concluded that policing institutions in many Western countries currently are undergoing substantial restructuring in the light of changing security discourses and new forms of governance coupled with an era of globalisation. In Sweden, the police currently face developments towards increased public demands on service delivery; changing societal demographics; new security discourses; transnational crime patterns; and increased demands of the police to serve in a 'multifunctional' fashion (Lauritz \& Hansson, 2013). Change pressures such as these have led to attempts of renewed definitions of purposes and methods of policing. Prominent 


\section{O. LINDBERG ET AL.}

examples on the level of reform are, for instance, the incorporation of new public management (NPM) as an administrative restructuring oriented towards service alignment. Also, on an organisational level, a need for change is evident and has been manifested in organisational countermeasures, such as moves from experiential models of policing towards knowledge- and problem-based policing, which builds on evaluation, the utilisation of research, the fostering of learning climates and overall ambitions to become a 'learning organisation' (cf. Andersson Arntén, 2013; SOU, 2012, p. 13). In policy discourse surrounding these transformations, a dominant theme of discussion has targeted the importance of leadership to achieve the successful implementation of changes. For instance, a recently conducted state investigation of the Swedish police organisation (SOU, 2012, p. 13), emphasised how the effective management of police 'for the future' is 'dependent on the development of modern leadership' (e.g. p. 32, emphasis added). However, what this 'modern leadership' is supposed to entail is not elaborated on in the report.

Given that leadership currently is promoted as a solution to many of the Swedish police's current challenges, we aim to exemplify how a practice theoretical analysis of leadership may highlight some of these issues.

The case study seeks to answer how police leaders' accounts of leader practice relate to expectations from higher ranks (above), subordinates (below) and police policies concerning leadership. The case consists of interviews with 28 lower or middle managers in the police (11 women and $17 \mathrm{men})$, referred to as police leaders in the present chapter. These leaders were selected from two counties in Northern Sweden and from different ranks of the police organisation, from field officers to the heads of units. They all have responsibilities for staff that perform police work such as patrolling, crime-prevention, investigations or crime-fighting. The police leaders are supposed to assume three roles; as being accountable for operations, as employer representatives, and as leadership practitioners (Rikspolisstyrelsen, 2011b).

With the objective of examining how police leaders' experiences of leadership relate to expectations from higher ranks, from subordinates and from policy, we conducted a content analysis and categorisation of interview statements from 28 police leaders (in quotations named as woman 1-11, man 12-28). This method was combined with analysis of Swedish police leadership expectations as expressed in policy documents.

In order to conceptualise leadership as processual and rooted in performance, the study investigated the relationship between different accounts of leadership performances by constructing different domains of expectations. The domains are empirical categories (originating in the data sources) aimed at making comparisons and cross-references of different expectations. As such, they are constructed simply as the source of the leaders' perceived expectations. The domains were constructed as expectations from policy, expectations from above (i.e., higher ranking topmanagement) and expectations from below (i.e., the subordinated employees). After describing these domains of expectations, the results focus upon how police 
leaders describe their own leadership performances in their day-to-day practices of leadership.

\section{Expectations in Official Police Policy}

Three documents are paramount in defining Swedish police leadership: the police's organisational core values (Rikspolisstyrelsen, 2008), the police's employee policy (Rikspolisstyrelsen, 2011a), and the police's internal leader criteria (Rikspolisstyrelsen, 2011b). These documents are linked to each other with several cross references and can be said to constitute three pillars in defining Swedish police leadership on a policy level. Through content analysis of these documents, we identified 41 different expectations. These are exemplified in the following (for the full presentation, see Figure 1).

Within the core values, three central concepts are put forth as guiding principles for all of the police undertakings. The core values state that the police should work towards increased engagement (from employees internally and externally with local communities); that the police should work in a manner of efficiency (with an orientation towards results); and that the police should strive to be available (both externally and internally).

Building on the core values, the employee policy operationalises a number of desirable leader traits and expectations of leaders regarding what roles to take on in relation to subordinates, stakeholders, and the professional mandate the police must uphold. These roles are described in detail through a number of prescribed performances. Furthermore, the employee policy also discusses leadership on three hierarchical levels: direct leaders (i.e., first-line managers within the police), indirect leaders (i.e., middle management level) and, finally, strategic leaders (who, as the name implies, function on a top-tier strategic level). These levels of leadership are developed within the police's official leader criteria, which further details leadership performances.

Altogether, the policy texts give direction regarding desirable performances connected to the leaders. For instance, the leaders are expected to demonstrate proactivity, pathos, development orientation and facilitation skills in relation to their subordinate workgroups.

\section{Expectations from Top Management and Subordinates}

Starting with what can be referred to as 'top-down' desirable leadership performances, the interviewed leaders describe what kinds of demands and expectations they experience from above. Statements in this section concern performance management as the ability to make the unit perform well and maintain budget. Police leaders' experiences with pressures from above mainly concern expectations on leaders to act as employer representatives and to work towards measurable goals, which includes expectations of effectiveness, economy and performance. Personnel issues (HR management) are largely absent in the expectations on leaders from above. 


\section{O. LINDBERG ET AL.}

The respondents' descriptions of demands and expectations from subordinates (bottom-up) are more varied. 'Soft' issues, such as being a facilitator and working with personnel issues, are mixed with more performance-oriented, result-focused and 'hard' issues. The facilitating areas of demands and expectations concern creating a good work environment and pleasant work conditions for employees. Another considerable area of expectations from below on their leadership performances concerns being a good employee representative by representing the unit from the bottom towards the top of the system, which includes acting as a representative for their employees, shielding the employees from adverse organisational changes and voicing their concerns towards top management.

They also experience expectations of authority from employees, which includes being an employer representative and explaining directions from above. The expectations are also about proactive performances, such as developing the work conditions and creating cohesive activities for the unit.

\section{DOMAINS OF EXPECTATIONS}

Expectations expressed in policy combined with police leaders' perceived demands from below and above are illustrated in Figure 1. Each circle represents a domain of expectations. The letter A signifies expectations from above, and B represents expectations from below. Numbers within parentheses denote how frequently different expectations were mentioned in the interviews.

As the analysis shows, expectations from below show the greatest discrepancy from official policy with a number of expectations of leaders that cannot be found in policy, such as questions about salaries, benefits and vacations. Instead, expectations from above are more formalistic, emphasising result orientation and efficiency. The co-occurrence of expected leadership performances between different domains of expectations are found regarding the leader's role as an authority and employer representative. An interesting finding is also that the majority of expectations formulated in the policy arena do not seem to be reflected in leaders' perceived expectations of their leadership, neither from above nor from below.

\section{Leader Practice as the Management of Expectations}

When the interviewed police leaders describe their own leadership, the most common descriptions are more congruent with demands and expectations from below than from above. The expressions of their own leader practice show that they predominantly, and much more than what is expected and demanded from both higher ranks and from employees, act in a facilitating manner by being stafforiented, being caring, being supportive, being inclusive, being responsive, listening, motivating joy for work and encouraging staff to take responsibility. As a couple of respondents highlighted: 


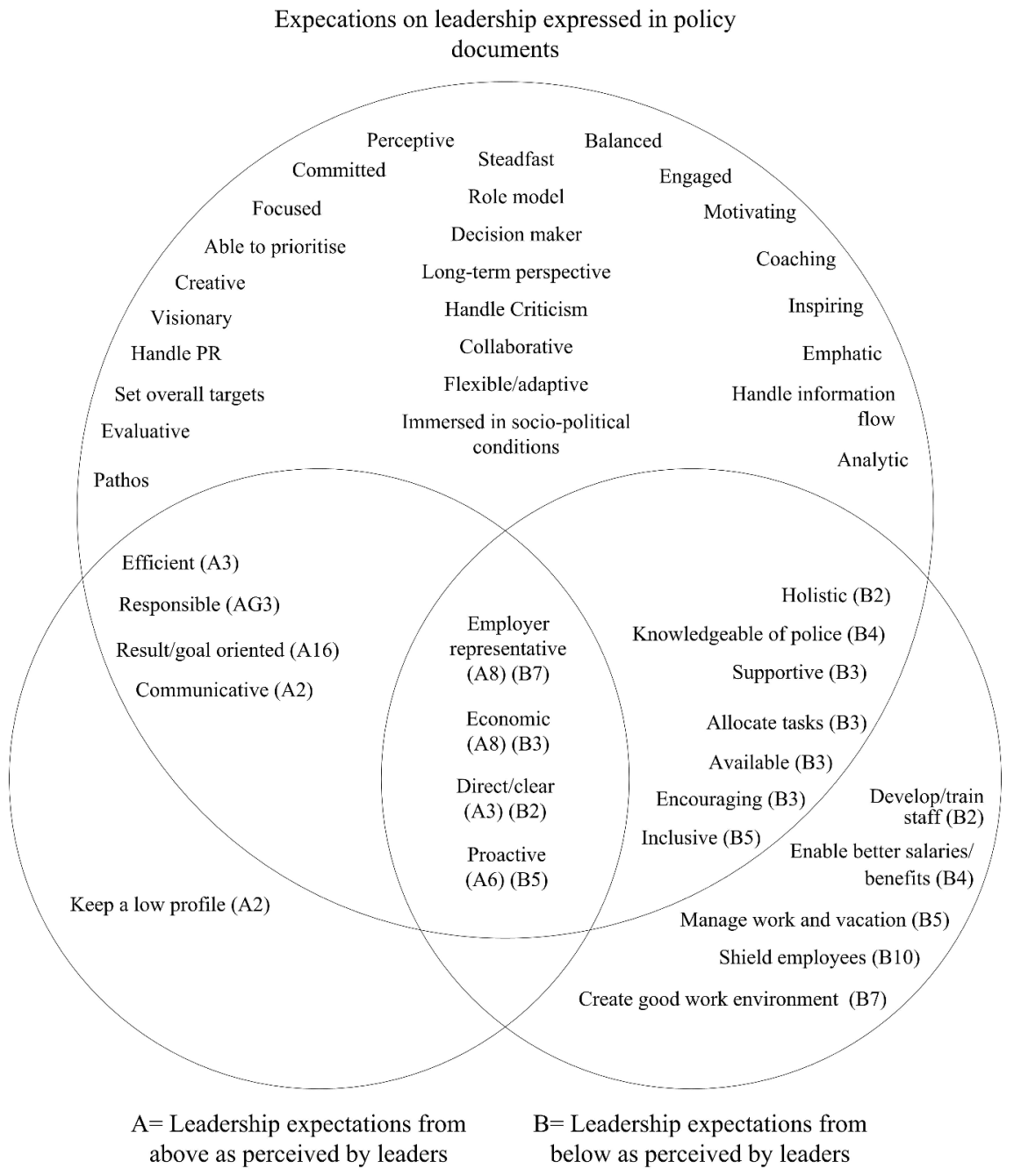

Figure 1. Domains of expectations on leadership performances

I treat people with respect. I'm good at listening and interpreting my subordinates and the general climate at work. My motivation is that they should enjoy their work, and that they should be as content as possible. (Woman 9) 


\section{O. LINDBERG ET AL.}

[My leadership style] is in any case non-authoritarian. What I strive for is that when we, me and my staff, begin a session we plan the day together ... we discuss it together. I listen to what they think we need to do, as well as the demands that are put on us. It is important to do this together. (Man 22)

The descriptions of the respondents' own leadership also show that they value engagement and a motivating approach to leadership, where self-expectations such as being gentle, positive and humorous are important.

Concerning actions of authority (such as being clear and decisive, brave, daring, not afraid of conflicts, exact, accurate, demanding, honest, trustworthy and loyal), the leaders' descriptions of their own practice and expectations from both topdown and bottom-up are very similar.

I believe that they [employees] think I'm kind, but at the same time rather clear and decisive (...) If I think something is not working well (...) I tell them immediately: this wasn't that good. They shouldn't need to second guess what I think and what I value. (Woman 11)

In the same manner, another respondent also emphasised clarity and decisiveness as important facets of self-expectations:

I'm rather direct and clear in regarding what I stand for and think. I (...) try to be as fair as possible. And I'm rather clear about how I want things to be.

I'm also rather good at giving feedback and I'm not afraid to say what I find to be demanding things in the system. (Man 24)

Having authority is thereby something that in this study shows to both be expected and acted upon in the leader practice within the police.

Concerning being able as a leader to navigate in the organisation, the respondents emphasised how these abilities were dependent on communicative performances. Expectations regarding experience, skill and strategic performance are mostly of interest in policy texts and are not perceived as important leadership performances from leaders themselves or from above or below. Interesting to note is also that the interviewed leaders refer much less to performances such as being well-organised, goal-focused and result-oriented as a part of their daily leader practice than what is visible in their expressions of top-down and bottom-up expectations. In particular, they describe performance management in terms of expectations from above:

Performance management and good economical results are the big thing right now and have been for a while. Everything seems to be about money and that is often in conflict with being an operative manager and in need of handling acute operations. I can't think of economical things at the same time as I need to handle a mountain rescue where I need a helicopter. (...) Economical demands is the toughest thing to handle when it at the same time requires that we should perform better and deliver more, while at the same time, we get lesser time for the staff. (Woman 2) 
Performances concerning defending and representing the unit's staff against top management is a lesser part of the leaders' descriptions than expected by their subordinates. Instead, they describe some aspects that are neither referred to in policy nor in expectations from above or below that concern authenticity in leadership. Authenticity is described as being able to show weaknesses and allow for being personal.

Yes, I'm stubborn, that I can tell you and then I have problems with dropping questions when I feel I have right even though others say I'm wrong. That is a weakness that I have trouble letting things go. (Man 12)

\section{THE ROLE OF CHANGE AGENTS FROM A PRACTICE THEORY PERSPECTIVE}

Focusing on the teleoaffective structure of leadership practice is asking what matters to these leaders and what makes sense for them to do. By looking at different domains of expectations perceived from above, below and from official policy, we get an overview of different sets of expectations, how they interact or, by contrast, how expectations are not congruent at all. In the second step, we analysed how leaders' account of their own practice related to these domains of expectations.

As opposed to much research on leadership, the practice theory approach does not focus on individual styles, traits and behaviours of leaders. In these other approaches, leadership styles, traits and behaviours tend to be viewed as universal - transferable - and, as such, either effective or ineffective. The practice theory perspective, on the other hand, recognises the contextuality of performance in organisations. Understanding why a certain way of doing things is working or not working to achieve a given goal must be understood by the analysis of context, organisational culture, views of followers and the perceived purpose of the organisation as well as the leaders themselves. In short, an analysis of teleoaffective structure recognises both the contextual as well as the processual nature of leadership.

The other main advantage of a practice theory analysis of leadership concerns the clear focus on performance rather than person or function. Leadership performances can be (and most probably are) carried out by people other than leaders. It is, as stated in the introduction, less a question of who leads than what leads in a given situation. Although we have not had the opportunity to do so in our empirical example presented, we can also imagine an analysis of material arrangements (such as geography/location, infrastructure, etc.) that might have more impact on leadership performances than any leadership method or style does.

We also assert that the teleoaffective elements of human performance - a structure - do not rid agents of agency. Plenty of room exists for both individuality and unexpected outcomes of performance. As Schatzki (2001b) concludes, practice is a process and is therefore becoming. A discourse perspective, as an example of a related form of analysis, should, according to Schatzki, be seen as a product (or a 


\section{O. LINDBERG ET AL.}

snapshot) of this process. In addition, a practice theory analysis of teleoaffective structure does not conflate to rational choices of autonomous individuals. Teleoaffectivity is governing practices and constitutes the history from which humans act and interact. Future actions also shape and reshape this structure.

Interviews and document (policy) analysis are well-suited for the purpose of describing teleoaffective structure. Through interviews, the interviewing researcher has the opportunity to directly ask about what they feel is expected of the leaders. In addition, people have seemed to be quite capable of describing what they do and what they feel are expected of them, as opposed to being asked to account for their beliefs and conceptions of certain phenomena that might be the target of other analyses. Talking about practice is concrete and makes the interview run more smoothly. Policy is also a strong source of mapping expectations, as policy contains explicit formulations of desirable performance. However, policy analysis alone is not sufficient for describing teleoaffective structure of practitioners. On the contrary, policy is, in this example and in many other studies, shown to have a limited impact on practitioners' views. Rather, policy constitutes an important point of reference for interview accounts, in particular, with reference to the expected role as change agents.

There are, however, two important limitations to the analysis we have exemplified in this chapter. First, the analysis of teleoaffective structure through policy and interviews does not primarily describe what leaders actually do or how leaders and followers interact in the construction of leadership. This is why we recommend that practice theory analysis should also incorporate observational data for a rich description of practice. Observation in the form of shadowing (Czarniawska, 2008), where the researcher can also ask questions about motives and goals (why did you do this?) and emotions (how do you feel about this that you do), would be well-suited for this kind of analysis, as it allows for a fine-grained analysis of how practice is accomplished through the 'here-and-now' of situated practicing. Secondly, and contrasting with the first limitation, our chapter does not offer an analysis that specifically targets how leadership practice is connected to what Nicolini (2010, p. 1392) calls the "elsewhere-and-then" of other practices. This type of analysis could take into account how leadership practice is contextualised relative to the historical change of production, division of labour or other cultural and historical conditions. Theoretically, a practice theory framework allows for analysis that acknowledges the local routines of activity while not losing sight of how practice is embedded within, and infused with, wider assemblages of practices (i.e., what Nicolini, 2010, discusses as an analysis that has the capacity to zoom in as well as zoom out). To explicate the connections between local leadership practice and historical, translocal conditions is an important array for further research into the subject. 


\section{Features of a Police Leadership Teleoaffective Structure}

Turning to our empirical example of a practice theory analysis, we are able to draw two main conclusions concerning police leadership practice in times of reorganisation and globalisation. These conclusions are particularly aimed at the readiness of police leaders to constitute change agents (cf., Hooper \& Potter, 2000) in these processes.

First, we conclude that the police leader is in a squeezed position between different domains of expectations. While this conclusion is not new (e.g., Gabel, 2002), we can show how these different and opposing demands result in how these leaders make sense of them in their own leadership performances. The policy texts give the impression that leaders are expected to do everything in every aspect of leadership - from strategist to facilitator. Concurrently, the expectations from above and from below are different from their own ways of leading their units. This mismatch can create a situation in which police leaders experience high pressure pertinent with a squeezed position. The squeeze position of leaders is also highlighted in research into other organisations due to, for instance, economic cutbacks or problems in directing soloists in highly professional organisations (Haikola, 2000; Hailey \& James, 2004). The following is an example of how a police leader reasons about the pitfalls of managing a manifold of expectations:

Today, leaders in my position should be partly operative and partly strategic. We are expected to be quite go-ahead, really. We are expected to have a big range of competencies. (...) [The police] is such a complex organisation and the demands are so various. It's not easy to make it ... it's no assembly line. Sometimes I wonder, the manager position, it's no easy task, both for men and women. And I've noticed that, many are young and have great ambitions, they're very competent, educated, and on top of that have a family to care for. And then to combine this with work ... I mean, a lot of young managers burn out pretty fast because the demands from all directions are quite harsh. (Man 25)

Our second empirically supported conclusion is that these leaders incline towards leading in a way that is more congruent with demands from the lower ranks and immediate daily practice rather than leading in ways that correspond with demands from higher ranks and policy. In short, the Schatzkian 'site' of Swedish police leadership seems to be one that is characterised by everyday issues and similar understandings between leaders and followers. These results align with conclusions from previous studies by, for instance, Andersson and Tengblad (2009) and Harding, Lee, and Ford (2014), who question the passive 'lynchpin' role of middle managers as transmitters of change in the rational top-down implementation of reforms. Rather, a practice theory approach to leadership enables an analysis that recognises that leaders actively engage in re-interpretations and sense-making of strategic plans based on their outlooks on the organisation. 


\section{O. LINDBERG ET AL.}

The case study indicates that such outlooks in large part coincide with traditional 'shop-floor' understandings of whom and what the police should be in contemporary society. It seems as if the interviewed police leaders are more immersed in the daily work of the police and therefore embody police organisational culture more than previously observed. A possible explanation for this is that leaders work within the boundaries of a police culture shared by subordinate workgroups. As indicated by, for instance, Fielding (1994) and Reiner (2000), such a culture contains shared values and norms and a clear us-vs.-them perspective. However, previous research has constructed 'them' as an external outgroup associated with the general public.

Our results indicate that a similar internal us-vs.-them mentality exists within the police between top management and other leader tiers. Thus, it seems that an increasing adoption of new public management strategies and a focus on organisational innovation (cf. Kingshott, 2006; Gordon, 2010) that is promoted from the top management level in the police may result in suspicion and resistance from leaders in lower management positions. Our results indicate that, in light of current changes, these leaders adopt a 'grounded' leadership in which traditional values and employees are safeguarded and prioritised in contrast to the demands posted by top management within the police. As changes presently are implemented from top-down in the Swedish police, our results point towards the conclusion that leaders are reluctant to assume the role of 'change agents'. In conclusion, there is a need for studies on daily leadership practice, as such studies hold great potential to problematise some 'root assumptions' (cf. Alvesson \& Sandberg, 2011) regarding leadership in times of change and turmoil.

\section{REFERENCES}

Alvesson, M., \& Sandberg, G. (2011). Generating research questions through problematization. Academy of Management Review, 36(2), 247-271.

Alvesson, M., \& Sveningsson, S. (2003). Managers doing leadership: The extra-ordinarization of the mundane. Human Relations, 56(12), 1435-1459.

Andersson Arntén, A.-C. (2013). Är Polisen en lärande organisation? En intervjustudie om polisens ledningsstruktur. Stockholm: Rikspolisstyrelsen.

Andersson, T., \& Tengblad, S. (2009). When complexity meets culture: new public management and the Swedish police. Qualitative Research in Accounting \& Management, 6(1/2), 41-56.

Avolio, B. J., Walumbwa, F. O., \& Weber, T. J. (2009). Leadership: Current theories, research, and future directions. Annual Review of Psychology, 60, 421-449.

Bryman, A. (2004). Qualitative research on leadership: A critical but appreciative review. The Leadership Quarterly, 15(6), 729-769.

Butler, J. (1993). Bodies that matter: on the discursive limit of "sex". New York: Routledge.

Czarniawska, B. (2008). Organizing: How to study it and how to write about it. Qualitative Research in Organizations and Management: An International Journal, 3(1), 4-20.

Chia, R. (2004). Strategy-as-practice: Reflections on the research agenda. European Management Review, 1(1), 29-34.

Chia, R., \& Holt, R. (2006). Strategy as practical coping: A Heideggerian perspective. Organization Studies, 27(5), 635-655.

Fielding, N. (1994). Cop canteen culture. In T. Newburn \& E. Stanko (Eds.), Just boys doing business: Men, masculinity and crime (pp. 163-184). London: Routledge, 
Fleming, J. (2008). Managing the diary: what does a police commissioner do? Public Administration, $86(3), 679-698$.

Gabel, S. (2002). Leading from the middle: surviving the squeeze of apparently irreconcilable forces. Leadership \& Organization Development Journal, 23(7), 361-371.

Gill, R. (2002). Change management - Or change leadership? Journal of Change Management, 3(4), 307-318.

Gordon, R. D. (2010). Dispersed leadership: exploring the impact of antecedent forms of power using a communicative framework. Management Communication Quarterly, 24(2), 260-287.

Hake, U., Rantatalo, O., \& Lindberg, O. (forthcoming). Police leaders make poor change agents: Leadership practice in the face of a major organisational reform. Policing \& Society.

Haikola, L. (2000). Att dirigera solister. Om ledning och ledarskap vid Lunds universitet (Directing soloists. Management and leadership at Lund University). Report No. 2000:208. Lund University: Utvärderingsenheten.

Hailey, J., \& James, R. (2004). "Trees Die From the Top": international perspectives on NGO leadership development. Voluntas: International Journal of Voluntary and Nonprofit Organizations, 15(4), 343-353.

Harding, N., Lee, H., \& Ford, J. (2014). Who is “the middle manager”? Human relations, iFirst article.

Hooper, A., \& Potter, J. (2000). Intelligent leadership. Random House: London.

Kingshott, B. F. (2006). The role of management and leadership within the context of police service delivery. Criminal Justice Studies, 19(2), 121-137.

Lauritz, L. E., \& Hansson, J. (2013). Lära är livet - att vara polis i en föränderlig värld (Learning is life - Being a police in a changing world). In N. Eklund \& L. Landström (Eds.), Polisen - verksamhet och arbete (The police - Activity and work) (pp. 66-83). Malmö: Liber.

Lindberg, O. (2012). 'Let me through, I'm a doctor!' Professional socialization in the transition from education to work. Academic Dissertation. Umeå University.

Lindberg, O. (2013). Gatekeepers of a profession? Employability as capital in the recruitment of medical interns. Journal of Education and Work, 26(4), 431-452.

Lindberg, O., \& Rantatalo, O. (2015). Competence in professional practice: A practice theory analysis of police and doctors. Human Relations, 68(4), 561-582.

Nicolini, D. (2010). Zooming in and out: Studying practices by switching theoretical lenses and trailing connections. Organization Studies, 30(12), 1391-1418.

Reiner, R. (2000). The politics of the police ( $3^{\text {rd }} \mathrm{ed}$.). Oxford: Oxford University Press.

Rikspolisstyrelsen (2008). Polisens värdegrund (The police's core values). Stockholm: Rikspolisstyrelsen.

Rikspolisstyrelsen (2011a). Polisens medarbetarpolicy (The police's employee policy). Stockholm: Rikspolisstyrelsen.

Rikspolisstyrelsen (2011b). Polisens ledarkriterier (The police's leader criteria). Stockholm: Rikspolisstyrelsen.

Sandberg, J., \& Tsoukas, H. (2011). Grasping the logic of practice: Theorizing through practical rationality. Academy of Management Review, 36(2), 338-360.

Schatzki, T. (2001a). Introduction: practice theory. In T. Schatzki, K. Knorr Cetina, \& E. Von Savigny (Eds.), The practice turn in contemporary theory (pp. 1-14). New York: Routledge.

Schatzki, T. (2001b). Practice mind-ed orders. In T. Schatzki, K. Knorr Cetina, \& E. Von Savigny (Eds.), The practice turn in contemporary theory (pp. 50-63). New York: Routledge.

Schatzki, T. (2005). Peripheral vision: The sites of organizations. Organization Studies, 26(3), 465-484.

SOU (2012:13). En sammanhållen svensk polis (A unified Swedish police). Stockholm: Regeringskansliet.

Weick, K. E. (1993). The collapse of sensemaking in organizations: the Mann Gulch disaster. Administrative Science Quarterly, 38(4), 628-652. 
O. LINDBERG ET AL.

Ola Lindberg

Department of Education

Umeå University, Sweden

Oscar Rantatalo

Police Education

Umeå University, Sweden

Ulrika Haake

Department of Education

Umeå University, Sweden 
KIRSI KALLIO

\section{DILEMMAS IN AUTOMATION ENGINEERS' DAILY WORK AND THE CHANGING FORM OF LEARNING}

\section{INTRODUCTION}

The profitability of automation firms is increasingly grounded in high-level automation software solutions and their related performance and consultation services rather than the production and delivery of basic automation products (Ylén et al., 2010). In this type of business activity value is created in a close, innovationoriented collaboration between suppliers and their clients during the entire life cycle of an automation solution. According to the seminal analysis of Victor and Boynton (1998) this type of co-configurative production is the latest stage in the historical development of forms of work that evolved as a resolution for the emerging contradiction between fixed products on the one hand, and the rapid changes of technology and customer needs on the other.

This shift towards a historically new type of work and production is widely recognised among scholars (Normann, 2007; Prahalad \& Krishnan, 2008). However, the related changes in learning and competence development have been rarely analysed empirically at the level of mundane work actions. This chapter is an attempt to eliminate this gap by focusing on the dialectical, and often very contradictory, relation between the long-term transformation of business activities and existing forms of work as they are related to learning and competence development.

The primary aim of this chapter is to investigate changes in learning in the automation service work on the front line of providing customers with high-level automation software solutions. Secondly, a Boundary-Crossing Change Laboratory (BCCL) (Engeström, Engeström, \& Vähäaho, 1999), an application of the Change Laboratory (CL) (Virkkunen \& Newnham, 2013) is presented as a method to develop the needed new forms of work-related learning. The case example is Metso Automation, a firm that operates internationally producing automation solutions for the process industry. In 2003 researchers from the University of Helsinki (including the author) carried out a Boundary-Crossing Change Laboratory investigation at Metso Automation in order to identify the central current challenges and possibilities for the further development of its relatively new venture of providing process optimisation software systems for pulp production. 


\section{UNDERSTANDING CHANGES IN WORK AND LEARNING: AN ACTIVITY THEORETICAL APPROACH}

The transformation of any business activity is a lengthy process that comprises of qualitatively different phases in which also the nature of learning challenges changes. The cultural-historical activity theory (CHAT) (Engeström, 2005; Leontjev, 1978; Vygotsky, 1978) offers a perspective to view these changes in learning within the context of developing activity (see Toiviainen in this volume). From the activity-theoretical perspective an actor's interaction with the object of his/her actions is seen as mediated through various culturally evolved tools and signs that function as psychological instruments for self-control. Individual actions are realised within collective activity. The object (and the expected outcome) of a given activity represents the true motive of activity both collectively and for individuals (Leontjev, 1978).

An activity system is constantly working through contradictions within and between its elements. The contradictions typically emerge in the historical transformation when the traditional mode of production gives way to the new one. These inner structural tensions are understood as a driving force for expansive learning that is, resolving current contradictions by developing a qualitatively new form of activity based on an expanded understanding of the object of this activity (Engeström, 1987). On the management level, this kind of an expansive development of business activity typically starts from a diffuse need state created by lessening economic viability and success in meeting the needs of markets.

The inner systemic contradictions between and within the elements of activity system cannot be observed directly; instead they can only be identified through their empirical manifestations (Engeström \& Sannino, 2011, p. 369). These manifestations occur as different kinds of dilemmas, disturbances and double-bind situations when contradictory demands draw practitioners to opposite directions in their daily work actions (Engeström, 2001, pp. 134-137). I concentrate on the early phases of Boundary-Crossing Change Laboratory (BCCL) in Metso Automation. In the BCCL, the difficulties in automation engineers' work, as well as individual attempts to solve them were systematically analysed. The analysis aimed at identifying the systemic contradictions in the present activity. I also describe how this analytic work in BCCL-sessions led to the reconceptualisation of the purpose of the business activity, particularly in regard to the provision of optimisation software solutions.

\section{PULP PRODUCTION OPTIMISATION BUSINESS OF METSO AUTOMATION}

The case of optimisation automation in Metso Automation is an illustrative example of learning challenges emerging in the subsequent stages of expansive transformation of business. The provision of optimisation solutions differs essentially from the provision of basic automation products, which was the primary business of Metso Automation before the optimisation software business developed. Rather than as a single product, optimisation software is conceived as an offering consisting of physical products, software, and related services. The 
concept of offering thus implies a reconfiguration of the whole process of value creation so that the process - rather than the physical product - is optimised. As Normann (2007, p. 117) states, an offering is a genetic code for learning. This means that value is not created in separate transactions of physical products or related services between suppliers and their customers, but rather in collaborative, innovation-oriented learning between them.

Metso Automation's innovation-oriented work with customers is a representative example of co-configurative production. Drawing on Victor and Boynton's (1998) presentation Engeström (2005) summarises the criteria of coconfiguration: (1) adaptive "customer-intelligent" products or services or, more typically, integrated product-service combinations, (2) continuous relationships of mutual exchange between customers, producers, and the product-service combinations, (3) ongoing configuration and customisation of the product-service combination over lengthy periods of time, (4) active customer involvement and input into the configuration, (5) multiple collaborating producers that need to operate in networks within or between organisations and (6) mutual learning from interactions between the parties involved in the configuration actions (Engeström, 2005, pp. 438-439).

Traditionally, when a pulp mill orders a basic automation system, the provider, in this case Metso, produces the equipment, installs it, and leaves the pulp mill when the equipment fulfils the requirements set by the customer. A basic automation system is built from standard elements that can be installed with little customisation and is subject to normal wear and breakage requiring regular service and periodic replacement. After installation of the automation system, its maintenance is typically handed over to Metso's service organisation. Thus, the provision of basic automation systems corresponds to the traditional linear sequence from product development to installation and then to service.

The strict division of labour between product development, installation, and maintenance services is not, however, possible in the provision of optimisation software. Unlike basic automation products, optimisation software is never ready in the conventional sense. It functions well only if continuously re-customised according to changes in the production process and the requirements set for its optimisation. In Metso Automation, work related to a specific client-software combination is carried out by a working pair of a product development unit engineer and an engineer from the Metso's local service organisation. The local service engineer helps a product developer in the installation of the optimisation software and subsequently handles the maintenance and re-configuration of it in collaboration with representatives from the customer's mill. The primary responsibility for the functionality of the product lies with the product developer, who designs the solution. The optimisation software solution is always designed specifically for the each phase of the pulp production process. Thus developing and configuring it requires in-depth knowledge and specialisation know-how related to every single phase of the pulp process.

After the implementation stage, primary responsibility for the individual customer moves to the local service engineer who consults as necessary with the 
product developer. However, this division of responsibility cannot be as clear-cut as in provision for the traditional automation system, because the reconfiguring often involves product development, which has to be carried out together with the clients in their plants. Figure 1 shows the main activity systems involved in the provision of optimisation software solutions.

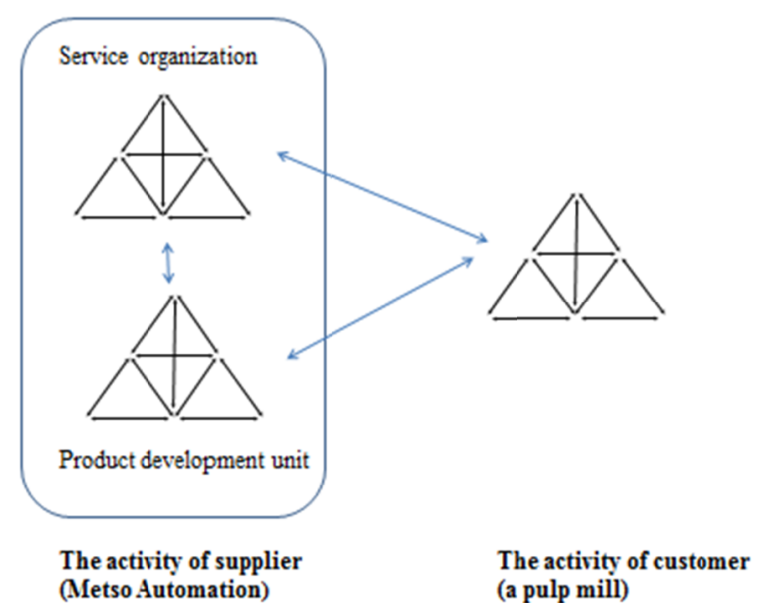

(Metso Automation) (a pulp mill)

Figure 1. The structure of activity systems involved in the provision of optimisation software solutions

\section{BOUNDARY-CROSSING CHANGE LABORATORY AS A METHOD FOR CHANGE INTERVENTION}

As the object of activity expands to a qualitatively new form, actors' possibilities to control and influence their work practices are changed. The difficulties stemming from the historically evolved contradictions within and between the elements of developing activity, however, can seldom be solved on the level of situated individual action (Virkkunen, 2006). Neither is it possible to study them outside of this action. Potential solutions to overcome structural contradictions can be figured out by analysing actors' experiences together with the historically evolved possibilities. In other words, managing dilemmas experienced in daily work requires perspectival thinking through a collective inquiry and a multi-voiced dialogue, by means of which the actors may view their joint activity from different perspectives (Haynes, 2001). Through perspectival thinking actors are able to understand the present as an outcome of past development and the future - not as a continuation of the present - but as a new perspective that harnesses the historically evolved possibilities.

The boundary-crossing Change Laboratory is an intervention method for organisational actors to examine their historically evolved activity and the systemic 
causes of any acute disturbances and double-binds they experience in their mundane work actions (Engeström, Sannino, \& Virkkunen, 2014). The guided instruments of the Change Laboratory enable the participants to analyse difficulties they may find in their present activities (contradictions) by moving between the first-hand empirical data and abstract models for analysing empirical observations, as well as proceeding from analysis of the past and present activities towards envisioning future models. With the help of generic conceptual models and tools the practitioners can identify the historical and systemic causes of their daily problems and envision a new model of activities that may make it possible to overcome them.

Metso Automation's Change Laboratory process targeted the implementation of a new strategy for expanding the business towards innovation-oriented collaboration with its clients. The product development unit, the pulp product group, spearheaded the realisation of the principles of this new strategy in the provision of optimisation software solutions. In the early 2000 s the emphasis on product development of optimisation software solutions shifted from the development of new products to the improvement of existing ones. The number of installed optimisation software systems increased rapidly, highlighting the need to rationalise the work and to develop tools for it. In creating a new model for the next phase of optimisation business, crossing boundaries between the product development, installation, and maintenance was central. Therefore three service engineers from one of Metso's local service offices were also invited to take part in the project which was then re-named the Boundary-Crossing Change Laboratory (BCCL).

The BCCL-process consisted of 12 two-hour sessions supervised by two researcher-interventionists. In the sessions, the product developers of the pulp group $(\mathrm{N}=5)$ and the service engineers from the local service unit $(\mathrm{N}=3)$ analysed and discussed their work activities and presented possible solutions for their current problems. The researchers has collected ethnographic data on the participants' daily work activities and prepared "mirror data" that the participants used in analysing the past history and current challenges of the software optimisation process. The conceptual models of the BCCL served as the tools for the analysis. The data gathered for the mirror data of the BBCL consisted of several interviews with engineers, other staff members from Metso Automation, and with some key customers. Local service engineers' actions were also observed and videotaped when they visited customers' pulp mills and interacted with customers' operators and engineers.

The discussions of each laboratory session were transcribed for the use of researchers. While analysing these transcriptions, I paid attention to the many implications of various kinds of dilemmas, disturbances and double-binds in the daily work of local service engineers operating on the front line with their customers. These disturbances and double-binds are dilemmatic situations experienced by service engineers. They seemed to stem from adhering to the official rules, contract, and divisions of labour that made it dilemmatic to carry out their work. I will analyse these difficulties and individuals' attempts to solve them 
in order to shed light on the historical changes in automation service work and related learning. The research questions are: (1) what kinds of disturbances, dilemmas and double-binds occur in the daily work of automation service engineers, and (2) what do these reveal about the changes of learning and competence development in the frame of historically transforming business activity.

\section{EXPERIENCED DILEMMAS IN AUTOMATION SERVICE ENGINEERS WORK}

Participants of boundary-crossing Change Laboratory identified many dilemmas in their daily work on software optimisation. These difficulties were classified into two clusters. The first concerned dilemmas in the development of expertise and the division of labour between product developers and service engineers, and the second involved problems in accounting systems and principles of compensation. Service engineers working on the front line with customers seemed to experience these difficulties more acutely than the product developers.

\section{Dilemmas Related to the Development of Expertise and the Division of Labour}

Installations of hi-tech optimisation solutions demand very different kinds of expertise than the provision of basic automation products. Therefore three dilemmas related to the development of expertise in automation service work as well as the division of labour between product developers and service engineers were reported during the BCCL-sessions.

The first difficulty was that the local service engineers were highly motivated to work and invest in personal development as pulp production optimisation experts, but they faced difficulties related to their capabilities for development. While new technology forced them to improve their expertise in one phase of pulp production they were also responsible for the configuration of software solutions for several other phases of the pulp production process. This situation created tension between the need to deepen their knowledge and to "survive with a customer" as follows:

Interviewer: Could it be said that you handle every phase of the production process, that is, all of the optimisation packages?

Service engineer 1: No, you cannot deeply understand all of them.

Service engineer 2: You can have a superficial knowledge of all of the packages, but not an in-depth knowledge of them all.

Service engineer 1: You do not have enough time to properly learn all of them.

Service engineer 2: It is a totally different level of knowledge to properly know and, have an in-depth understanding of each of the packages than to just survive with a customer ... and to know what is happening in all of the 
mills. Here, in customer interactions it is more important to survive than to have deep knowledge.

The second kind of dilemmas in service engineers' work was related to the possibilities to configure optimisation software solutions according to "specs", the pre-defined documented specifications for the software. On one hand, working according to standards ("specs") was experienced as a good way to work. For example, basic automation systems are built according to the requirements set by the client using standard elements and, thus, can be installed according to standard instructions with little customisation. In this case, "specs" serve as rules to guide, instruct and restrain how an automation system is installed or maintained according to quality standards.

On the other hand, the optimisation software is not a standard mass product. The production processes of different pulp mills vary greatly; thus every optimisation solution is customised according to client-specific requirements. To do this, a customer's mill is carefully audited before the final compilation of the software. An important part of product development takes place during the customisation phase in close collaboration with the customers' production organisation at the mill.

Therefore, the installation of optimisation packages and their continuous configuration call for a competency in analysing the variations in the customer's production process and mill environment. Local service engineers found it important to question the ideas concerning the relationships between variables in the client's production process. Questioning was not possible by simply following the pre-defined instructions:

Service engineer: If you know something about the pulp production process you more eagerly question your own ideas compared to the person who does not know as much and only follows instructions.

The service engineers pointed out that it was important to document not only how things should be done but also the systemic ideas behind instructions, and, why things should be done in a specific way, that is, to understand the relationships between production process parameters. In actual work, these kinds of instructions were used, however, not as restrictive rules, but rather as tools for analysing and learning to understand the ideas behind optimisation solutions and the variations in pulp production processes.

Thirdly, one of the main problems of the service engineers was that they did not get involved in the installation projects early enough, which prevented them from effectively learning and knowing the client's process. Keeping the software up-todate called for continuous small-scale development, which requires a thorough understanding of both the optimisation solutions and the phases of production. In addition, the service engineers wished to get more involved in the product development.

During the BCCL intervention sessions, a solution to this problem was proposed. Whereas product developers would continue to take the main responsibility for the development of new software solutions, service engineers, for 
their part, would be in charge of the small-scale further development of the software.

\section{Dilemmas in Accounting Systems and Principles of Compensation}

Another cluster of dilemmas experienced in daily service work emerged from the notion that the logic of creating value in the optimisation business was different from that of providing basic automation products. When providing basic automation, the client pays for the system and for potential maintenance services that are charged based on work hours. However, when providing optimisation packages, the amount paid by the customer is to a great extend based on improvements in the client's pulp production process gained through the application of optimisation software. In BCCL-sessions four problems involved in the dilemmas between traditional accounting systems and the new principles of compensation were discussed.

First, to manage this new kind of business related to optimisation packages, Metso Automation had launched a new type of gains-sharing agreement with its customers called a "development agreement." According to this contract, although the client was paying a basic price $(20 \%)$ for the software package, $80 \%$ of the price was tied to the attainment of agreed improvement targets in certain production parameters. Through the development agreement activity, the object of work of local service engineers had expanded from carrying out separate service tasks to the total management of customer relationships. On the one hand, this overwhelmed them but, on the other, it proved inspiring:

Service engineer 2: Traditionally different persons have done the work, while others calculated euros and profits. However, in the development agreement activity, the local godfather is completely in charge of the management and profitability of contracts.

Service engineer 1: On the other hand, it is good for us to learn to manage financial budgets and projects.

Service engineer 2: You get an overall picture of projects and know what is covered.

Service engineer 1: You can consider the input and efficiency of your work.

However, the service engineers argued that the firm's accounting system was still based on automation products (the old value creation logics) rather than client relationships and, therefore, did not properly reflect the nature of their work with optimisation solutions. The installation of the optimisation software and work in development agreement activity were classified as separate products although they were intimately interlinked.

The accounting system that was based on a mass-production type product classification overlooked the possibility that the service engineer would carry out co-configuration type complementary work for the customer - typically the small- 
scale further development of the software systems done as part of service and maintenance work in a client's mill. Therefore the service engineers claimed that this kind of development is done "secretly."

The second example of the incongruity between the accounting system and the nature of the actual work is found in so-called "covert sales". Historically in Metso Automation, specialists carry out marketing and sales. However, while interacting with customers in their mills local engineers sell many additional product components and services which are not always taken into account when calculating their efficiency. The nature of local work with a customer is auspicious for "covert sales" as described here:

Service engineer 1: Covert sales rely on a different approach than traditional sales. If you enter a mill with the intent to sell something, the client will feel defensive. However, we do not disturb the harmony of the mill. We can enter into the daily interaction smoothly.

Service engineer 2: And we are viewed more as work mates and our suggestions are taken seriously. Customers do not perceive us as the henchmen of the supplier.

Service engineers also felt that when the optimisation software was functioning well they did not need to invest so many hours; solid results in the client's processes were achieved and full compensation was collected by the firm. However, in more problematic cases, they invested many hours, while the gains in productivity were small and the firm did not earn much.

Thirdly, the engineers pointed out that when the client's process was optimised with the help of the software, great gains were initially achieved with a reasonable amount of work. As the process approached optimal values, however, it was more and more difficult to achieve remarkable improvements. Since the client was paying for improvements, there was a risk that the business would become less and less profitable for Metso Automation. For these reasons, local service engineers recommended calculating the profitability of a client relationship over a longer time span, which would better reflect the nature of their work. It would also reflect the results of preparatory work and any sales they made in their collaborations with clients.

The fourth notion discussed was that in official development agreements, Metso and the client agreed that: "the customer orders and enables the provider to maintain and develop any optimisation software the provider had previously installed." However, according to the spirit of Metso Automation's renewed strategy the relationship with a client should not be based on a reactive request for help, but should be based on the possibility of proactive improvements in production with the aid of optimisation packages. In addition, local service engineers saw the future of their work as being more proactive:

Service engineer 2: We think that the core of this whole optimisation business is that we can identify problems in client's process earlier than the clients themselves. 
To summarise, dilemmas in accounting systems and principles of compensation reflected the changing object of business. Instead of installation and reconfiguration of the optimisation software, service engineers viewed the analysis of problems in clients' production processes and their refinement together with them as the real object and motive of their work. In addition, representatives of the clients viewed the development of production, not the maintenance of the software as such, as the primary object of the collaboration with Metso Automation.

As the solution to this dilemma product developers and service engineers drafted a new model for the next phase of the activity related to optimisation business. This model was based on the idea of a new form of consultative service used to analyse bottlenecks and developmental possibilities across the customer's entire pulp mill or within a single production line.

\section{FINDINGS IN THE FRAME OF HISTORICALLY TRANSFORMING BUSINESS ACTIVITY}

The analysis of the first research question, what kinds of disturbances, dilemmas and double-binds occur in a daily work of automation service engineers, revealed two clusters of dilemmas. The first cluster concerned the development of expertise in automation service work and the division of labour between product developers and service engineers. The competence needed in optimisation software business was different from that for providing basic automation products. Also the strict division of labour between product developers and service engineers was eroding due to the need for continuous re-configuration of optimisation software. Normann (2007, pp. 65-66) highlights the fact that we have to move away from focusing on competencies required to manufacture and sell a product and focus on the much broader set of competencies related to the design and functioning of a valuecreating system. This kind of competency requires flexible movement across strict divisions of labour and existing rules typical for mass production.

The knowledge needed in the product development of optimisation software solutions was largely embedded in the mastery acquired by the individual product developers. Similarly, local service engineers gained a wealth of knowledge while interacting with customers. This kind of craft-specific learning is typical when there are changes in market conditions (Victor \& Boynton, 1998, pp. 19-46). Since Metso's optimisation business had expanded rapidly, documenting individual knowledge into specifications and instructions was necessary. However, due to the co-configurative character of optimisation software, these documents could not be used to draft the compelling rules as they could in traditional mass production. An engineer needs a deep understanding of the optimisation products as well as the customers' processes under changing circumstances. Understanding this value creation system is the core of the co-configurative business (Normann, 2007). Attempts to standardise and codify such knowledge through rules would always lag behind the knowledge needed to solve problems experienced by a customer in the field. 
The second cluster of dilemmas emerged from the notion that the logic of creating value in the optimisation business was different from that of providing basic automation products. The real object of collaboration with a client was not the maintenance of software, as such, but the development of the client's production process. As service work became more innovative and proactive, service engineers had to survive by developing individual solutions (e.g., "secret development", "covert sales") for problems that arose. They had to learn something not recognised within the organisation's formal system. Since this kind of work was not legitimised through the firm's existing accounting system and contracts, learning remained mostly informal. Ironically, from the viewpoint of the renewed strategy of Metso Automation, this informal learning on the "peripheral" front line could be strategically significant (see Ahonen, 2005).

The participants of the BCCL drafted an idea for a new form of consultative service that could identify the bottlenecks and developmental possibilities in a customer's production process. The proposed model could be seen as a qualitatively new way to create value and the requirement for expansive learning: from the confines of a strict division of labour and product-based rules to a completely new kind of activity. In this model, the object of Metso engineers' work is no longer optimisation software and related services. Rather, software is viewed as a shared tool, or platform (cf. Ciborra, 1996), for information sharing and collaborative learning between three parties, the product developers, service engineers and representatives from client mills.

The second research question analysed is, what do the disturbances, dilemmas and double-binds reveal about the changes in learning and competence development within the framework of historically transforming business activities? The findings show that these experienced problems arose from historical changes in the methods associated with the production and delivery of automation systems and their maintenance based on mass production as they moved towards co-configurative work with customers. This refers to the change from product-based value creation towards an offering-based business (Normann, 2007; Victor \& Boynton, 1998). Local service engineers witnessed this change on the front line while working with their customers. It could be interpreted as the traditional division of labour and rules covering service work (accounting systems and contracts) partially contradicted the nature of this new, evolving form of work and thus leading to a contradiction between old and new elements of activity.

The findings on the changing forms of learning are summarised in Table 1 that presents: (1) the object (= the motive) of learning, (2) the main methods of learning, (3) the carriers of learning and (4) the division of labour and the rules used for learning. The columns include the current form of learning in automation service work at Metso Automation and the emerging new form of learning. The columns in the middle summarise the dilemmas analysed, which mediate the transformation from the current to the new form of learning. 
Table 1. Dilemmas of daily work and the changing form of learning in automation service work

\begin{tabular}{llll}
\hline $\begin{array}{l}\text { Components of } \\
\text { learning }\end{array}$ & $\begin{array}{l}\text { Current form of } \\
\text { learning }\end{array}$ & $\begin{array}{l}\text { Dilemmas } \\
\text { experienced } \\
\text { in daily work }\end{array}$ & $\begin{array}{l}\text { Newly emerging } \\
\text { form of learning }\end{array}$
\end{tabular}

\begin{tabular}{|c|c|c|c|}
\hline $\begin{array}{l}\text { 1. The object of } \\
\text { learning }\end{array}$ & $\begin{array}{l}\text { Characteristics of one } \\
\text { or two optimisation } \\
\text { software solutions; } \\
\text { configuring them for } \\
\text { the requirements of the } \\
\text { clients' processes; } \\
\text { reactively solving } \\
\text { problems in the } \\
\text { optimisation of } \\
\text { production process }\end{array}$ & $\begin{array}{l}\text { Need to learn the } \\
\text { phases of pulp } \\
\text { production in- } \\
\text { depth; manage the } \\
\text { entire customer } \\
\text { relationship over a } \\
\text { longer time span }\end{array}$ & $\begin{array}{l}\text { Proactively analyse } \\
\text { bottlenecks and } \\
\text { developmental } \\
\text { possibilities of a } \\
\text { customer's } \\
\text { production process } \\
\text { in collaboration } \\
\text { with other partners } \\
\text { involved }\end{array}$ \\
\hline $\begin{array}{l}\text { 2. The method of } \\
\text { learning }\end{array}$ & $\begin{array}{l}\text { Adaptive guidance } \\
\text { training by product } \\
\text { developers; individual } \\
\text { survival while } \\
\text { handling problems at } \\
\text { hand }\end{array}$ & $\begin{array}{l}\text { Managing the } \\
\text { diversity of and } \\
\text { constant changes } \\
\text { in clients' } \\
\text { production } \\
\text { processes by } \\
\text { innovating } \\
\text { solutions for the } \\
\text { problems at hand }\end{array}$ & $\begin{array}{l}\text { Negotiation and } \\
\text { problem-solving } \\
\text { across the } \\
\text { boundaries of } \\
\text { different areas of } \\
\text { expertise and } \\
\text { organisations }\end{array}$ \\
\hline $\begin{array}{l}\text { 3. The carrier of } \\
\text { learning }\end{array}$ & $\begin{array}{l}\text { Pre-defined } \\
\text { instructions and } \\
\text { descriptions of } \\
\text { software and } \\
\text { production processes } \\
\text { as rules for work; tacit } \\
\text { knowledge embedded } \\
\text { in daily work }\end{array}$ & $\begin{array}{l}\text { Complementary } \\
\text { (tacit) knowledge } \\
\text { gained through } \\
\text { daily work; need } \\
\text { for documenting } \\
\text { and sharing this } \\
\text { knowledge as tools } \\
\text { for work }\end{array}$ & $\begin{array}{l}\text { Optimisation } \\
\text { software as a } \\
\text { shared platform for } \\
\text { joint development } \\
\text { and learning }\end{array}$ \\
\hline $\begin{array}{l}\text { 4. Division of } \\
\text { labour and rules } \\
\text { used in learning }\end{array}$ & $\begin{array}{l}\text { Based on the lines and } \\
\text { phases of optimisation } \\
\text { and areas of expertise; } \\
\text { based on the stages of } \\
\text { the lifecycle of the } \\
\text { optimisation product }\end{array}$ & $\begin{array}{l}\text { Flexible movement } \\
\text { across strict } \\
\text { divisions of labour } \\
\text { and existing rules }\end{array}$ & $\begin{array}{l}\text { Contributions to } \\
\text { the partially shared } \\
\text { object of activity } \\
\text { (developing } \\
\text { client's pulp } \\
\text { production) on the } \\
\text { basis of different } \\
\text { expertise }\end{array}$ \\
\hline
\end{tabular}


Since the knowledge related to optimisation software solutions was poorly documented and distributed among involved actors, the automation engineers' main method of learning was adaptive guidance training by product developers as well as individual survival in handling problems at hand. However, the changing object of service work activity demanded jointly understood tools in order to be able to negotiate across the boundaries between different areas of expertise and organisations. The existing main carriers of learning were pre-defined instructions for service work ("specs") and the tacit mastery of individual engineers. However, during the BCCL-sessions there were wide ranging discussions concerning the fact that the engineers' work rather than being seen as an object of service optimisation solutions, would be better understood if it were seen as shared tools or a platform for joint development and learning between the involved parties.

The existing division of labour is strictly based on different areas of expertise and on the stages of the lifecycle of the optimisation product (product development, sales, and service). However, the changing business demanded that all the involved actors should contribute to the partially shared object, i.e., development of client's pulp production process, which requires flexible movement across strict divisions of labour and existing rules.

\section{CONCLUSIONS}

Even though the shift towards more collaborative business with customers is widely recognised, the related changes in learning and competence development have been rarely empirically analysed in mundane work situation. This chapter has expanded the analytical scope by investigating the changes in learning in automation engineers' work in the context of a long-term transformation process of business activity. The structural contradiction found between the traditional product-based value creation of the mass production and the offering-based emerging business of co-configuration, helps us understand the learning challenges in automation service work on the front line with customers and propose concrete steps for competence development.

A formative intervention method, the boundary-crossing Change Laboratory, is presented as a tool for practitioners to study difficulties in their work activities from the perspective of the historical development of their productive activity. Through systemic-level collective analyses participants are able to generate new models for their future activities and forms of learning needed in changing business. As Virkkunen and Ahonen (2001, p. 71) argue, in the conditions of rapid technological and business development this kind of meta-level method is clearly needed.

\section{REFERENCES}

Ahonen, H. (2005). Työyhteisön oppimiskäytäntöjen strategisuus (The strategic potential of local learning practices. English abstract). Hallinnon tutkimus, 24(2), 96-112.

Ciborra, C. (1996). Improvisation and information technology in organizations. ICIS 1996 Proceedings, $26,369-380$. 


\section{K. KALLIO}

Engeström, Y. (1987). Learning by expanding. Helsinki: Orienta-konsultit, Oy.

Engeström, Y. (2001). Expansive learning at work: Toward an activity theoretical reconceptualization. Journal of Education and Work, 14(1), 133-156.

Engeström, Y. (2005). Developmental work research: Expanding activity theory in practice (Vol. 12). Berlin: Lehmanns Media.

Engeström, Y., Engeström, R., \& Vähäaho, T. (1999). When the center does not hold: The importance of knot-working. In S. Chaiklin, M. Hedegaard, \& U. J. Jensen (Eds.), Activity theory and social practice: Cultural-historical approaches (pp. 345-374). Aarhus: Aarhus University Press.

Engeström, Y., \& Sannino, A. (2011). Discursive manifestations of contradictions in organizational change efforts: A methodological framework. Journal of Organizational Change Management, 24(3), 368-387.

Engeström, Y., Sannino, A., \& Virkkunen, J. (2014). On the methodological demands of formative interventions. Mind, Culture, and Activity, 21(2), 118-128.

Haynes, J. D. (2001). Churchman's Hegelian inquiring system and perspectival thinking. Information Systems Frontiers, 3(1), 29-39.

Leontjev, A. N. (1978). Activity, consciousness, and personality. Englewood Cliffs: Prentice Hall.

Normann, R. (2007, reprinted). Reframing business: When the map changes the landscape. Chichester: John Wiley \& Sons Ltd.

Pihlaja, J. (1995). Learning in and for production. An activity-theoretical study of the historical development of distributed systems of generalizing. Helsinki: Helsinki University Press.

Prahalad, C. K., \& Krishnan, M. S. (2008). The new age of innovation: Driving cocreated value through global networks (Vol. 1). New York: McGraw-Hill.

Victor, B., \& Boynton, A. C. (1998). Invented here. Maximizing your organization's internal growth and profitability. Boston: Harvard Business School Press.

Virkkunen, J. (2006). Dilemmas in building shared transformative agency. @ctivités, 3(1), 44-66, http://www.activites.org/v3n1/virkkunen.pdf

Virkkunen, J., \& Ahonen, H. (2004). Transforming learning and knowledge creation on the shop floor. International Journal of Human Resources Development and Management, 4(1), 57-72.

Virkkunen J., \& Newnham, D. S. (2013). The Change Laboratory. A tool for collaborative development of work and education. Rotterdam: Sense Publishers.

Vygotsky, L. S. (1978). Mind in society: The psychology of higher mental functions. Cambridge, MA: Harvard University Press.

Ylén, J.-P., Ventä, O., Tommila, T., Lappalainen J., Hirvonen, J., Karhela, T., Paljakka, M., Lehtinen, H., Heilala, J., Peltonen, J., Malm, T., Valkonen J., \& Voho, P. (2010). Automaatio liiketoimintaprosessien tukena (Automation supporting business processes). Finnish Technical Report. Helsinki: Tekesin katsaus 271.

Kirsi Kallio

Center for Research on Activity, Development and Learning (CRADLE)

Institute of Behavioural Sciences, University of Helsinki, Finland 


\title{
DAN RÖNNQVIST, ANDREAS WALLO, PETER NILSSON \\ AND BO DAVIDSON
}

\section{EMPLOYEE RESOURCING IN ELDERLY CARE}

\author{
Attracting, Recruiting and Retaining the Right Competence
}

\section{INTRODUCTION}

Caring for elderly people is a struggle for most public sector organisations around the world. Especially troublesome is the task of attracting, recruiting, and retaining competent employees to work in the elderly care sector (Johansson \& Moss, 2004; National Commission on Nursing Workforce for Long-Term Care, 2005). For instance, the expected labour shortage in the Western world and the upcoming retirements of so-called baby-boomers are expected to become particularly problematic in the elderly care sector by creating an imbalance between the future potential workforce and the number of senior citizens (Benjamin et al., 2008; Henkens, Remery, \& Schippers, 2008; McNeese-Smith, 2001). Another contributing factor is the difficulty connected with retaining employees for reasons such as low salaries and high workload (Castle \& Engberg, 2006).

In this chapter, the situation described above is studied within the context of the Swedish elderly care sector, which is currently confronting four main challenges. First, a substantial portion of the employees in this sector are nearing retirement. By 2030 , there will be a deficit of 150,000 health and elderly care employees with upper-secondary educations (Statistics Sweden, 2011). Second, the total number of Swedish citizens aged 65 or older will increase by approximately 600,000 from 2010 to 2030 (Statistics Sweden, 2011). Third, both the number of youths who choose to follow the health care education programme in upper-secondary school and the general attraction of the programme are decreasing (Statistics Sweden, 2011). Fourth, there is a gap between political visions of what health care work should be and the daily work practices in organisations in the labour market. There appears to be a lack of knowledge of human resource management and development issues in Swedish elderly care. According to Johansson and Moss (2004), elder care work in Sweden lacks clear career paths and effective strategies for recruiting personnel. Managers in elderly care do not appear to have the competence or the authority needed to translate political visions into practice.

When all of these factors are considered, ensuring the continued supply of competent personnel in the elderly care sector is a difficult and rather complex task. A possible scenario is that fewer employees will be available to care for an increasing number of elderly citizens. On the national level, this caregiver shortage 
may force public policy makers to find resources and strategies for employee resourcing that target both the labour market and the educational system. However, consistent with the fourth challenge described above, the important question of what actions can be taken at the organisational level has received less attention in both the public debate and in previous research. Rather than merely placing problems and potential solutions outside of the organisational sphere of influence and thereby viewing organisations as victims of these circumstances, more focus could be placed on the factors and processes at work within organisations. What strategies can be used to address these issues, and how can work organisation, management, opportunities for development, and the working environment encourage youths to seek employment in this sector? Given these questions, this chapter is dedicated to problematising the process of attracting, recruiting and retaining employees in Swedish elderly care from an organisational perspective. Naturally, macro-level factors influence these processes; however, this chapter primarily focuses on the opportunities for change within organisations.

\section{ATTRACTING, RECRUITING AND RETAINING PERSONNEL}

To understand employee resourcing activities in health care organisations, the importance of theories and models within a human resource management (HRM) and human resource development (HRD) framework has previously been emphasised (Buchan, 2006; Kabene et al., 2006). In this section, we draw on an HR system model that describes employee resourcing as three interlocked processes: inflow, internal flow, and outflow (Nilsson et al., 2011). The inflow process concerns how to attract and recruit new employees. Internal flow focuses on how to introduce, retain and develop those who are already employed. Outflow concerns the termination and relocation of employees. How these three processes are managed in practice is influenced by internal factors, such as goals and strategies, and external factors such as legislation and unions. Consistent with the aim of this chapter, the first two processes receive the most focus.

\section{Attracting Personnel}

Beginning with the question of how to attract competent personnel, the HR literature has devoted much attention to the concept of employer branding (Martin et al., 2004), which has also been addressed within the health care sector (Heilmann, 2010; Johnson \& Roberts, 2006). Employer branding encompasses activities that aim to strengthen the reputation and attractiveness of an organisation. For many organisations, this aim implies an offering that is more appealing than the offerings of other organisations. For instance, such offerings could include a high salary, career opportunities, or flexible working hours (Torrington et al., 2008).

The attractiveness of an organisation is dependent on several factors. One factor is a potential applicant's view of how s/he would fit into the organisation (Carless, 2005). For youths, another important issue is the possibility of balancing work and 
free time (Carless \& Wintle, 2007). However, different factors appear to have different levels of significance for work applicants during the various stages of the recruitment process. In the initial stages, factors such as salary, benefits, and development possibilities are regarded as the most important (Boswell et al., 2003). When the time comes to accept an employment offer, however, the focus of the applicant tends to shift to the reputation and size of the organisation as well as to the sector in which the organisation is located (Cable \& Turban, 2003). Furthermore, studies have shown that although opportunities for development are generally of great significance to an organisation's reputation, the actual work conditions and the match between competence and work content may even be more appealing to applicants (Thomas \& Wise, 1999). Thus, those who are already employed must promote both the occupation and the organisation to increase its attractiveness to potential employees (Osborne, 2001; Van Hoye, 2012).

In a recent study of employer branding in a Finnish hospital, Heilmann (2010) reveals a lack of structure and strategy for marketing activities. However, Heilmann suggests a number of possibilities for improving the situation, such as increasing visibility on the Internet, strengthening communication with educational institutions, and arranging recruitment events.

\section{Recruiting Personnel}

The primary functions of recruitment are to secure a sufficient number of applicants to the position at hand and to ensure that applicants have the competence that is required to perform the work. The goal is also to encourage the applicant to accept an employment offer (i.e., pre-hire outcomes), but it is also important to consider post-hire outcomes, such as ensuring that employed individuals will not terminate their employment prematurely (Breaugh \& Starke, 2000; Thomas \& Wise, 1999).

Ideally, a recruitment process begins with goal formulation. Based on these goals, a strategy is developed to cover issues such as who should be recruited and how, and when the recruitment should occur (Breaugh \& Starke, 2000). Price (2011) describes three common strategies for recruitment. The first strategy, 'the right person for the right job', implies that the newly employed is only expected to perform the appointed assignments. Organisations that apply this strategy typically have a traditional hierarchical order with clearly definable tasks. The second strategy, 'the right person in the right organisation', emphasises the importance of matching the newly employed with the organisational culture. Therefore the alignment of the personality of the employee with the organisational culture is more important than whether s/he has the required technical skills. The third strategy, 'the right person for the future', is based on upcoming needs and can be characterised as a more long-term approach. The traits of being flexible and development oriented are important in this strategy (ibid.).

In elderly care, the recruitment of competent personnel is an ongoing struggle. According to Johansson and Moss (2004), the recruitment base for work in Swedish elderly care has traditionally consisted of middle-aged housewives with 
young children, but new recruitment strategies are emerging in Swedish municipalities. The official strategy today is to handle recruitment by increasing the value of formal education while also broadening the recruitment base to include male care workers and minority ethnic care workers. However, evidence from Johansson and Moss's (2004) study suggests that this strategy has not yet been realised. The value of life experience, preferably working life experience, often outweighs the value of educational background.

\section{Retaining Personnel}

In regard to retention, studies show that if a recruiter provides applicants with accurate information, then those individuals are likely to remain in the organisation (Dahr, 2012). Another critical element is the orientation period in the organisation. Research has shown that it is important for the newly employed to quickly become embedded in organisations (Allen, 2006). If the introduction of employees is arranged in a group, follows a schedule and considers the previous knowledge and experience of participants, then individuals will become more embedded in the organisation than they would if other tactics were used. This greater involvement will in turn lead to a lower inclination to terminate employment (ibid.).

For organisations, it is important to consider the various reasons that employees terminate their employment. These reasons could be external factors, such as a partner procuring a job in another town; functional factors, such as a lack of competence or overqualification in relation to work tasks; or dissatisfaction with one's career and development opportunities or with one's salary. The reasons could also relate to social factors, such as whether one works well with co-workers, managers or clients (Nilsson et al., 2011; Tran et al., 2012). Studies indicate that social factors may be particularly relevant for understanding turnover in the health care sector (cf. Chou, 2012; Ellenbecker, 2004). For instance, the findings of a study of Canadian nursing homes (Monahan \& Carthy, 1992) show that fondness for residents was a major reason for nurse aides to remain in their jobs. In addition, the findings of Sellgren et al. (2007) suggest that leaders who create a work climate that promotes job satisfaction may reduce nursing staff turnover.

Capelli (2000) argues that organisations can take a number of different measures when confronting staff turnover issues. First, there are several forms of compensatory economic measures. These measures are short-sighted and easy for competitors to match. A more long-term measure is to tailor the work content to certain groups of employees (e.g., reducing low-qualification assignments). Another long-term measure is to introduce selective programmes that aim to enhance the ability of employees to balance their work and private lives. Such programmes could range from development and career planning to social networks. These measures are characterised by a view of individuals as complex with different needs and driving forces that may change over time (Schein, 1988). 


\section{METHODOLOGY}

The data presented in this chapter were collected in a Swedish municipality using a mixed-methods design. The empirical material originates from interviews with first-line managers in elderly care $(\mathrm{N}=3)$, interviews with the headmaster and two teachers from an upper-secondary health care programme $(\mathrm{N}=3)$, and a survey of final-year students in the programme $(\mathrm{N}=74)$. The respondents were selected in consultation with upper management in the municipality and the headmaster at the school that provided the health care programme. A criterion for selection was that the respondents needed to have broad experience working in their respective fields. To complement the interviews, a survey was distributed to the students in three classes during the final year of the programme. The response rate was 80 per cent (74 of 93 students).

The interviews with first-line managers and school staff followed a guide that addressed topics such as recruitment to elderly care, skill demands in elderly care, conceptions of the health care programme, and the transition from the programme to work in elderly care. The survey of the final-year students in the health care programme was performed using a questionnaire comprising 29 Likert-type items (1 through 7) covering topics such as factors influencing the choice of programme, preferences for future employment, and factors influencing the choice of future work.

The interview data were organised in relation to the themes of the study, namely, attracting, recruiting and retaining employees, and typical quotations were chosen to illustrate the interviewees' conceptions of these topics. The data from the questionnaire were analysed using descriptive measures. Two sections of the questionnaire, namely, 'Factors influencing the choice of programme' and 'Factors influencing the choice of future work', were factor analysed (using principal component analysis for extraction and varimax rotation) to reduce the data and to find a clear structure for presentation and overall analysis. For the first section, three factors were obtained, and for the second section, two factors were obtained. The factors were used to construct composite indexes, which are presented in Table 1. The findings were fed back to and validated by the respondents of the interview study.

Table 1. Indexes based on factor analysis in the student questionnaire

\begin{tabular}{ll}
\hline Section of items in the questionnaire & Index \\
\hline Factors influencing the choice of & 1. Parents, friends, academic counsellors, etc. \\
programme & 2. The school's reputation and the possibility of \\
& 3. future higher education after the programme \\
& 4. One's own choices early in life \\
\hline Factors influencing the choice of & 5. Work content \\
future work &
\end{tabular}




\section{RESULTS}

In this section, the results based on the interview and survey data are presented.

\section{First-line Managers}

The first-line managers list several factors related to attracting employees to work in the field of elderly care. Notably, the first-line managers view the entire process of attracting, recruiting and retaining personnel in relation to the low status of elderly care work. This factor is the single most important regarding employee resourcing.

According to the managers, work in the elderly care sector can be made increasingly attractive if employees were to express a more positive attitude to their work and through better marketing. When the managers describe the organisation and content of the actual work, they mention several aspects that can be improved. Such aspects include better schedules, higher salaries, increased benefits and development possibilities as well as a refinement of the work content with a stronger focus on care (i.e., outsourcing services such as cleaning). The managers also mention competence development through validation for an assistant nursing degree for those without formal education.

Regarding the status of work in the care sector, the managers anticipate that future qualification demands will increase as a consequence of caretakers needing more medical care. One reason for this change is that people are sent home from hospitals sooner and will thus need more qualified medical care in their homes.

There is going to be an increase in the demand for more specialised skills, especially in home care. Overall, there is a large group - and this will increase - of elderly people with psychological problems. Another big group are the cancer patients, who we are supposed to be able to work with. We will

have to strengthen our competence or organise specialised teams.

The managers anticipate that this change will increase the demand for responsibility, medical and technical competence, and the ability to cooperate with caretakers and their relatives.

The first-line managers are aware that students from the health care programme are unwilling to seek employment in the elderly care sector. One reason for this reluctance is that the practice period in elderly care occurs during the first year of the programme, while the practice period in medical care occurs in the final year. This situation is a signal to students that elderly care holds a lower status relative to medical care. Furthermore, the managers mention that the students falsely believe that they will not have the opportunity to use the skills that they have acquired during the programme if they choose to work in the elderly care sector. Finally, the difficulties in securing permanent employment in elderly care makes students even more reluctant to seek employment in this sector.

The role of first-line managers in the recruitment process is complicated. Their conception relates to the lack of clear, communicated policy regarding competence 
development or recruitment in the organisation. Furthermore, these managers do not have the authority to recruit employees on a permanent basis. The recruitment process could be simplified if the bureaucracy was not so complicated. Finding temporary workers is fairly easy, but it is difficult to find the right individuals for permanent employment.

\section{School Staff in the Health Care Programme}

The headmaster's and teachers' conceptions of the elderly care sector largely mirror those of the first-line managers. The low status of the elderly care sector emerges as the central factor in the school staff's description of the problem of attracting, recruiting and retaining employees. The negative image of the sector in the media is considered a serious obstacle, and a more positive portrayal of elderly care could improve this situation. Furthermore, several factors in the actual work situation contribute to these problems. The school staff believes that the status of the elderly care sector can be improved through better salaries and better working conditions.

The headmaster and the teachers also anticipate a future increase in qualification demands, including medical competence, the ability to work in a team, and social skills. The main reason for this development is that caretakers will need more medical care in their homes. As a possible consequence of this scenario, the status of the elderly care sector may improve, and the work may become more appealing.

The headmaster and the teachers also cite the influence of gender in relation to elderly care work. Female employees exclusively dominate the sector. A more gender-balanced workforce could make the work more attractive in the future. The school staff is aware that working life in its entirety is divided along gender lines and that this division influences students' choice of education and work early in life. A more gender-balanced care sector would be more likely to attract students. The different specialisations of the health care programme are also relevant to the problem of attracting and recruiting elderly care employees. Among the programme specialisations, both the social and natural science specialisations are regarded as good starting points for higher education. Students with good grades and a clear view of their academic career and future work choose these specialisations. The school staff notes that these students do not plan to work in elderly care at all. The general specialisation, by contrast, has the reputation of being easy and attracts students who do not intend to progress to higher education.

It has got the reputation of being an easy programme. It's just care! Social sciences and natural sciences, they have the tradition of being tough theoretical programmes, even if they also have some care. The general programme has the reputation of being easy.

The structure of the health care programme, in conjunction with factors such as the low status of the elderly care sector and gender, influences students' education and work choices. However, the headmaster and the teachers believe that this situation could, to a degree, be addressed by better cooperation between school and working 


\section{RÖNNQVIST ET AL.}

life. For instance, practice periods in elderly care must be further developed by providing a strong introduction, supervision and mentoring to make the sector more attractive. If the practice period in elderly care is moved from the first year to later in the programme, such a move may facilitate the transition from school to work and may also signal a higher status of the elderly care sector. Better marketing is another possible factor, but according to the school staff, providing better salaries and developing work content are the main areas to address.

\section{Students in the Health Care Programme}

Variables from the survey of health care programme students are presented to illustrate the problem of attracting, recruiting and retaining employees in elderly care, namely, factors influencing the choice of programme, the sector in which students wish to work, and their choice of future work.

Table 2. Factors influencing the choice of programme

\begin{tabular}{lll}
\hline Index & Mean $(1=\min , 7=\max )$ \\
\hline 1. & Parents, friends, academic counsellors, etc. & 2.58 \\
2. & The school's reputation and the possibility of future & 5.01 \\
& higher education after the programme & \\
3. $\quad$ One's own choices early in life & 4.24 \\
\hline
\end{tabular}

The analysis shows that the students' perception of the reputation of a particular school and the many possible alternatives for higher education after programme completion are the most important factors in choosing to study in the health care programme. The second most important factor for students is that they have often made the choice early in life to work in the field of medicine and care. The students' rate influences from parents, friends, academic counsellors and others as the weakest factor. These results imply that students have a fairly clear view of why they choose the programme and what they plan to do later in life.

Next, the students were asked to select the sector of the field in which they wished to work after completing their education. In the questionnaire, the students could choose between different alternatives in the health care sector or an open alternative, in which they were asked to state their preferences.

Table 3. Sectors in which the students wish to work after completing the programme related to specialisation

\begin{tabular}{lllllc}
\hline \multicolumn{6}{c}{ Specialisation } \\
\hline Sector & General & Social sciences & Natural sciences & Total \\
\hline Health/Medicine & 13 & 14 & 10 & 37 & $50.7 \%$ \\
Elderly Care & 3 & 2 & 0 & 5 & $6.8 \%$ \\
Disability Care & 3 & 7 & 0 & 10 & $13.7 \%$ \\
Other & 1 & 16 & 4 & 21 & $28.8 \%$ \\
\hline Total & 20 & 39 & 14 & 73 & $100 \%$ \\
\hline
\end{tabular}


Slightly more than half of the students report wanting to work in the health/medicine sector. The second most popular choice includes occupations other than the prescribed alternatives, such as social worker, teacher, policeman, firefighter, childcare worker, ambulance driver, psychologist, music therapist, orthopaedist, researcher, or some type of higher education. A mere 6.8 per cent choose the elderly care alternative. To further illustrate the low status of the elderly care sector, the students who choose this alternative are primarily from the general specialisation, which is perceived as the easiest of the three options.

In the last section of the questionnaire, the students were asked to rate the factors that influence their choice of future work.

Table 4. Factors influencing the choice of future work

\begin{tabular}{ll}
\hline Index & Mean $(1=\min , 7=\max )$ \\
\hline 1. Salary and career opportunities & 4.91 \\
2. Work content & 5.43 \\
\hline
\end{tabular}

Of the two factors influencing the choice of future work, the students rate the content of their future work as slightly higher than salary and career opportunities, although both factors receive medium-high ratings.

\section{DISCUSSION}

The main findings of this study confirm the situation described in the introduction of this chapter - the troubling situation regarding the process of attracting, recruiting and retaining employees in Swedish elderly care. The results from both the interviews and the survey reflect the low status of work in the elderly care sector as the main problem with attracting workers. With regard to the recruitment process, the limited authority of first-line managers, combined with the underdeveloped policies and strategies for recruitment, is viewed as a considerable obstacle. Cooperation between school and the workplace is another area for development that can facilitate the recruitment process. The problem of retaining employees is linked to low status, low salaries, poor development opportunities, inadequate cooperation between school and work, underdeveloped HRM strategies, and students' unwillingness to work in the elderly care sector.

In view of these main findings, the following discussion will be dedicated to three areas identified as needing further problematisation and development. The first area concerns employer branding-related problems, such as the low status of the elderly care sector (cf. Heilmann, 2010; Johnson \& Roberts, 2006). The poor reputation of the entire sector can affect the ability of a single organisation to attract and recruit employees who want to remain in the organisation (Breaugh \& Starke, 2000). Elderly care tends to become temporary employment or is viewed as an occupation suitable for the transition between education and career (Johansson \& Moss, 2004), and the students in this study have goals that do not include working in this field. One way to increase the attractiveness of the occupation is to 


\section{RÖNNQVIST ET AL.}

begin with the attitudes of employees. Employees are often the ambassadors of such organisations and important co-creators of the image that is mediated to the surrounding world by word of mouth information (Osborne, 2001; Van Hoye, 2012).

Here it would be possible for organisations to shift the focus from a negative form of employer branding to a positive one. In other words, a possible outcome of this kind of work would both alter the employees' notions of their own work situation and increase the status of this sector on the labour market. Another way of working with attracting and embedding new employees is to focus on the cooperation between the workplace and the school (Heilmann, 2010). For instance, by moving the period of practice from the first to the final year of the educational program would send a signal to students that elderly care requires formal competence (Johansson \& Moss, 2004). This change would also alter the conditions for attracting new employees and would allow better opportunities for such organisations to attract students as future employees.

The second area of development concerns the limited authority of first-line managers. These managers do not have the full authority to employ people permanently when vacancies arise. Reassignments and redundant employees have priority over this type of employment. Pinnington and Edwards (2000) claim that the ability to secure the right number of employees with the right competence at the right time is crucial for organisations to reach their goals. To have responsibilities for daily operations without the ability to employ the most suitable individuals is a paradox for first-line managers in elderly care. Such employment issues are often handled higher in the organisational hierarchy. Therefore, the firstline manager is forced to develop a personal strategy or an 'emergent strategy' (Mintzberg, 1998) of using short-term employment to solve the organisation's need for competence. This situation that arises when different levels of an organisation do not appear to cooperate is similar to what Mintzberg refers to as a 'disconnected strategy'. A comparison of this method of handling recruitment issues with Price's (2011) three strategies shows that none of these strategies is applied in this case. Rather, it appears that a fourth strategy - 'anyone will do' - best describes the situation. The assumption that anyone can work in the elderly care sector, as long as they have some type of work experience, remains prevalent in the sector (Johansson \& Moss, 2004). However, we have reasons to question whether this way of working is cost effective and successful. A dialogue-based model in which organisational and HR strategies are closely linked may be more successful (Torrington et al., 2008). In the long term, the current situation may lead to negative effects in both the quality and status of elderly care work.

The third area of development is related to the terms of employment (and working conditions). Organisations often encounter difficulties in offering full-time employment, salary increases, and opportunities for career development. Foremost politicians within the municipality need to know that these factors most likely have a negative effect both on the quality of work and on current and future possibilities to attract, recruit, and retain employees in the elderly care field. However, rather than focusing solely on economic incentives, policymakers must also address 
factors such as the balance between private life and work life, supportive leadership, and social networks (Capelli, 2000; Ellström, 2012; Sellgren et al., 2007).

\section{CONCLUSION}

In conclusion, the findings of this study indicate that problems with attracting, recruiting and retaining employees in the Swedish elderly care sector will continue to arise if businesses proceeds as usual. The HRM and HRD processes in this sector can at best be described as rather underdeveloped, which may constitute a threat to the quality of elderly care in terms of the negative effects on elderly citizens' health and wellbeing (cf. Kabene et al., 2006). The existing problems may also affect the municipality from the employer perspective, presenting difficulties in attracting competent employees. Of course, these two negative outcomes are interrelated and can be described as a negative spiral. However, this negative situation is not necessarily unchangeable. From an HR perspective, organisations may have more room to manoeuvre than their current practices reflect. The challenge for future processes of employee resourcing within the Swedish elderly care sector is to consciously work with HRM and HRD processes at both the operative and strategic levels and to integrate the inflow, internal flow, and outflow in the HR system (Nilsson et al., 2011).

\section{REFERENCES}

Allen, D. G. (2006). Do organizational socialization tactics influence newcomer embeddedness and turnover? Journal of Management, 32(2), 237-256.

Benjamin, A. E., Matthias, R. E., Keitzman, K., \& Furman, W. (2008). Retention of paid related caregivers: Who stays and who leaves home care careers? The Gerontologist, 48, 104-113.

Boswell, W. R., Roehling, M. V., LePine, M. A., \& Moynihan, L. M. (2003). Individual job-choice decisions and the impact of job attributes and recruitment practices: A longitudinal field study. Human Resource Management, 42(1), 23-37.

Breaugh, J. A., \& Starke, M. (2000). Research on employee recruitment: So many studies, so many remaining questions. Journal of Management, 26(3), 405-434.

Buchan, J. (2004). What difference does ("good") HRM make? Human Resources for Health, 2(6), $1-7$.

Cable, D. M., \& Turban, D. B. (2003). The value of organizational reputation in the recruitment content: A brand-equity perspective. Journal of Applied Social Psychology, 33(11), 2244-2266.

Cappelli, P. (2000). A market driven approach to retaining talent. Harvard Business Review, 78(1), 103-110.

Carless, S. A. (2005). Person-job fit versus Person-organization fit as predictors of organizational attraction and job acceptance: A longitudinal study. Journal of Occupational and Organizational Psychology, 78(3), 411-429.

Carless, S. A., \& Wintle, J. (2007). Applicant attraction: The role of recruiter function, work-life balance policies and career salience. International Journal of Selection and Assessment, 15(4), 394404.

Castle, N. G., \& Engberg, J. (2006). Organizational characteristics associated with staff turnover in nursing homes. The Gerontologist, 46(1), 62-73. 


\section{RÖNNQVIST ET AL.}

Chou, R. J. A. (2012). Resident-centered job satisfaction and turnover intent among direct care workers in assisted living: A mixed-methods study. Research on Aging, 34(3), 337-364.

Dhar, R. L. (2013). Reality shock: Experiences of Indian Information Technology (IT) professionals. Work: A Journal of Prevention, Assessment and Rehabilitation, 46(3), 251-262.

Ellenbecker, C. H. (2004). A theoretical model of job retention for home health care nurses. Journal of advanced nursing, 47(3), 303-310.

Ellström, E. (2012). Managerial support for learning at work: a qualitative study of first-line managers in elder care. Leadership in Health Services, 25(4), 273-287.

Heilmann, P. A. (2010). Employer brand image in a health care organization. Management Research Review, 33(2), 134-144.

Henkens, K., Remery, C., \& Schippers, J. (2008). Shortages in an ageing labour market: An analysis of employers' behaviour, International Journal of Human Resource Management, 19(7), 1314-1329.

Johansson, S., \& Moss, P. (2004). Work with elderly people. A case study of Sweden, Spain and England with additional material from Hungary. Consolidated report. Care work in Europe. Current understandings and future directions. Retrieved April 16, 2009 from http://www8.umu.se/socw/ forskning/WP9\%20consolidated\%20report.pdf

Johnson, M., \& Roberts, P. (2006). Rules of attraction. Recruit and retain the best staff with employer branding. Marketing Health Services, 26(1), 38-40.

Kabene, S. M., Orchard, C., Howard, J. M., Soriano, M. A., \& Leduc, R. (2006). The importance of human resource management in health care: a global context. Human Resources for Health, 4(20), $1-17$.

Martin, G., Beaumont, P., Doig, R., \& Pate, J. (2005). Branding: A new performance discourse for HR? European Management Journal, 23(1), 76-88.

McNeese-Smith, D. K. (2001). A nursing shortage: Building organizational commitment among nurses. Journal of Healthcare Management, 46, 173-186.

Mintzberg, H. (1998). The strategy concept. Five Ps for strategy. In H. Mintzberg, J. B. Quinn, \& S. Ghoshal (Eds.), The strategy process (pp. 13-21). Oxford: Prentice Hall.

Monahan, R. S., \& McCarthy, S. (1992). Nursing home employment: The nurse's aide's perspective. Journal of Gerontological Nursing, 18(2), 13-16.

National Commission on Nursing Workforce for Long-Term Care. (2005). Act now for your tomorrow. Retrieved February 25, 2009 from http://www.gwumc.edu/sphhs/departments/healthpolicy/chsrp/ downloads/FinalCommissionReport051105.pdf

Nilsson, P., Wallo, A., Rönnqvist, D., \& Davidson, B. (2011). Human resource development: Att utveckla medarbetare och organisationer (Human resource development: Developing co-workers and organisations). Lund: Studentlitteratur.

Osborne, S. E. (2001). Recruitment: Whose job is it anyway? Advances in Neonatal Care, 1(1), 59-61.

Pinnington, A., \& Edwards, T. (2000). Introduction to human resource management, Oxford: Oxford University Press.

Price, A. (2011). Human resource management. Andover: Cengage Learning EMEA.

Sellgren, S., Ekvall, G., \& Tomson, G. (2007). Nursing staff turnover: Does leadership matter? Leadership in Health Services, 20(3), 169-183.

Schein, E. H. (1988). Organizational psychology. Englewood Cliffs: Prentice-Hall.

Statistics Sweden. (2011). Trender \& Prognoser 2011. Befolkningen, utbildningen och arbetsmarknaden med sikte på år 2013 (Trends \& Forecasts 2011. Population, education and labour market in Sweden - outlook to year 2013). Stockholm: Statistics Sweden.

Thomas, K. M., \& Wise, P. G. (1999). Organizational attractiveness and individual differences: Are diverse applicants attracted by different factors, Journal of Business and Psychology, 13(3), 375390.

Torrington, D., Hall, L., \& Taylor, S. (2008). Human resource management. Harlow: Pearson Education. 
Tran, D., Davis, A., McGillis Hall, L., \& Jaglal, S. B. (2012). Comparing recruitment and retention strategies for rehabilitation professionals among hospital and home care employers. Physiotherapy Canada, 64(1), 31-41.

Van Hoye, G. (2012). Recruitment sources and organizational attraction: A field study of Belgian nurses. European Journal of Work and Organizational Psychology, 21(3), 376-391.

\section{Dan Rönnqvist}

Department of Behavioural Sciences and Learning

Linköping University, Sweden

Andreas Wallo

Department of Behavioural Sciences and Learning

Linköping University, Sweden

Peter Nilsson

Department of Behavioural Sciences and Learning

Linköping University, Sweden

Bo Davidson

Department of Behavioural Sciences and Learning

Linköping University, Sweden 



\section{RECOGNITION OF PRIOR LEARNING WITHIN ELDERLY CARE WORK ${ }^{1}$}

\section{INTRODUCTION}

In the last two decades recognition of prior learning (RPL) has emerged as a widespread practice as well as field of research around the world (cf. Evans, 2000; Andersson \& Harris, 2006; Harris et al., 2011, 2014; Andersson et al., 2013). Generally, RPL signifies practices where people have their prior learning and experiences - from work and from other contexts - identified, assessed, and documented, normally through formal credentials. A basic argument in the literature is that RPL is a beneficial tool to increase the employability of citizens at a relatively low cost. This would be beneficial for society, who will have to pay less social benefits etc. to unemployed people, as well as beneficial for the individual, who would be able to find a job and support her/himself. That is, formal credentials that correspond to the individual's prior learning and current, actual competence are seen as crucial for mobility. This is particularly the case in times of uncertainty when it is no longer possible to rely on informal recognition from one single employer, but when the individual has to prepare for mobility between work places, for example through getting credentials that could allow recognition from a new employer.

The history of RPL is long and diverse (Evans, 2000), e.g. with a long tradition in France of experiential learning as the basis for credits and degrees, and efforts in the US after World War II of valuing experiences of war veterans to help them reenter the civil labour market. The more recent history goes back to the early 1970s (see e.g. Michelson, 1996), when 'prior learning assessment' was introduced in the US in an effort to broaden access to higher education. Most RPL initiatives have one or more of the following aims: (i) social justice (in relation to individual opportunities, broader access to education, etc., such as in the example from the 1970s), (ii) economic development (making it possible to use existing vocational/professional competence more effectively in the labour market, an idea developed in several locations, for example, in the UK where RPL was introduced in the 1980s), or (iii) social change (making the actual competence of the population visible creates better conditions for changing society; this is an idea mainly promoted in post-apartheid South Africa, starting in the 1990s) (Andersson et al., 2003).

The case discussed here is an in-service training process in the elderly-care sector in which recognition of prior learning was said to be a central component, 
but nevertheless one component among many others. One central component of the process was of course the new learning that would take place through the in-service training, new learning that ideally would build upon and integrate with participants' prior learning. Typically, earlier in-service training programmes in this context did not seem to have taken the participants' prior learning into account when choosing what and how to teach and study. In-service training was often reported by the employees (i.e. care workers) to repeat what they already knew and, therefore, they found it uninteresting and un-engaging. It often took the form of lectures - one-way communication - and was fragmented. In the studied project, we identified an ambition to engage in a holistic approach to in-service training, an approach where prior learning was assessed and then complemented with educational activities leading to additional new learning, and formal credentials. Furthermore, the process was clearly integrated with the care-workers' workplaces. The manager and a supervisor (one of the assistant nurses) in each unit collaborated with an educational provider. Consequently, the starting point in the design of the process was shaped by the idea that workplace experience is important in relation to formal educational requirements. That is, the educational provider and the employer worked closely together on planning and carrying out the in-service training programme, and care-workers' experiences gained through the years within the occupation were acknowledged and given credit in relation to formal educational requirements. Thus, this project provides an interesting empirical example from which questions of experience, learning, and recognition can be problematised.

The chapter is based on a study of parts of a large governmental project in Sweden called 'Steps for skills' aimed at supporting the municipalities in their work to improve quality and in-service training in the care sector (health care and social care) for elderly people (Step for skills, 2007). The reason for initiating this project was related to the demographic situation in Sweden where the elderly population is increasing and interest in becoming an assistant nurse is decreasing. However, according to the committee for the project, the greatest problem was that people working in the care sector do not have the 'correct' educational background. They often have a diploma from upper secondary school, but not from the healthcare programme. Here, it should be noted that in the care sector, formal credentials and diplomas are important as part of the quality system. The requirements are strict concerning doctors, nurses, and assistant nurses, and demand is growing, at least in the Swedish context, that care workers should be licenced assistant nurses.

The aim of this chapter is to discuss in what ways recognition of prior learning and prior experiences exists as part of the process of in-service training, and whether new learning is an aspect of this process. To understand these concerns, 26 semi-structured interviews (Kvale, 1996) were undertaken with a total of 30 care workers, assistant nurses (some of them acting as supervisors of participating care workers), local managers, and teachers. The aim of the interviews was to see how the informants perceived their participation and work within the in-service training programme. Altogether, 14 participants, six local managers, five supervisors, and five teachers were interviewed. All the interviewees were female. Some of them 
were interviewed twice (two managers, two supervisors, and three participants), at the beginning of the process and four months after the process had ended. Twenty interviews were individual, and six were group interviews, with two to five care workers in each interview. The selection of interviewees was based on the nursing homes participating in the project in one specific municipality, which was chosen because it had made rapid progress with the project. We covered the entire project in this specific municipality so that we could develop a broad and deep understanding of the project.

The analysis of interviews has been conducted using a qualitative interpretative approach focusing on discerning categories related to how the in-service training in the project was perceived by the interviewees regarding the role of experience, learning, and recognition. Firstly, we discuss the way the process of in-service training was organised and how prior learning was assessed. Secondly, we try to discern what role is ascribed to prior learning in the process of training/learning. Thirdly, we problematise the relation between experience, learning, and recognition.

\section{ORGANISING IN-SERVICE TRAINING BASED ON RPL}

The six nursing homes participating in this project were organised into three groups, with one privately owned and one municipally owned nursing home in each. Each group also consisted of an educational provider which had the task of carrying out the process of in-service training based on the health-care programme and on recognising participants' prior learning. The process was carried out using two different modes of organisation. At three nursing homes, the participants worked every second week as usual, without any interruptions from the recognition and training process, and during the other weeks they went to the school that was carrying out the RPL/training process. At two nursing homes, the participants participated in the process for one day a week. In the first week they were engaged in self-study for one day, and they were also guided by their supervisor, an assistant nurse from the nursing home. In the second week, the teacher visited them on one day and gave lectures and conducted discussions to establish the extent of their prior learning. The process in which the participants at these five nursing homes participated was planned to take approximately seven months to one year to finish (compared to one and a half years to finish the programme if one studies full time in the 'traditional' programme as an adult). After this, all the participants were expected to receive a degree from the health-care programme, and thus be able to be employed as assistant nurses.

However, at the sixth nursing home, all the employees were already assistant nurses. Thus, here they chose to organise a process of recognising prior learning in relation to the course of ethics in the health-care programme, as that course had been extended in terms of content (and credits) compared to the same course a few years ago when these employees received their degrees.

As a way of conducting these processes of RPL, the participants at the different nursing homes were involved in activities that could be related to both a process of education and teaching and to a process of recognition and assessment of prior 
learning. Teaching was conducted by a teacher who gave short lectures related to the module to be assessed. Furthermore, the participants had to discuss cases among themselves, and also to discuss these cases with their supervisors in 'learning conversations'. In these learning conversations the supervisor brought an issue or a case into the discussion, and the participants were encouraged to reflect on the issues discussed while the supervisor guided the conversation so as to involve everyone.

Assessment, including RPL, was carried out by teachers from the three educational providers. Generally, the assessment of the participant's knowledge was made by means of discussions and written assessments. A central component was the use of cases that the participants had to discuss, both orally and in writing. The aim of the assessment was to discover firstly what the participants already knew in relation to the health-care programme, and, secondly, what parts of the programme they needed to study more - by reading and doing assignments.

We can see how in-service training based on RPL in this case is a collective and individual process of teaching, assessment, and learning. On the one hand, the participants participate in a collective learning process based on discussions relating to prior experiences. Furthermore, their learning is based on short lectures by the teacher, and on reading books and doing oral and written assignments. On the other hand, their prior learning is assessed, although it is hard to distinguish exactly to what extent knowledge based on prior learning is being assessed, and to what extent it is the result of new learning (partly based on prior experiences). In the following sections, we will illustrate in greater detail what role prior learning has in the process of recognition of prior learning, and describe the relation between experience and learning that is constructed.

\section{THE ROLE OF PRIOR LEARNING}

In the next section, we will analyse the role of prior learning in the process of inservice training in which RPL was an integrated part. We identified three areas as specifically characterising this process. These areas seemed to interact in the construction of prior learning as a central part of the process, and therefore we wanted to analyse them further. The three areas were: the individual's prior knowledge acting as a starting point, discussion as a main working form, and production of new knowledge.

\section{The Individual's Prior Knowledge as a Starting Point}

A prominent feature of the process of recognition of prior learning is the actual focus on participants' prior learning and knowledge. That is, the results indicate how recognising prior learning is not only part of the project's rhetoric, but also a central aspect of the actual process. As one local manager expressed it: 'the focus is on ... how the specific individual's learning looks like and how that individual apprehends him/herself' (Manager 9). The process concentrates on what the individual needs (in relation to the individual background as well as certain 
criteria), instead of on what someone else decides that they have to study. As a supervisor expressed it when she spoke about this process:

Here, the way they learn makes them say: "But we know that". And then the teacher knows - I don't need to waste any time on that. Here, we can focus on what we need. That's the difference I believe. (Manager 9)

What is apparent is the focus on individuals and their prior experiences, learning and knowledge - that is, on what an individual knows, which is the starting point for developing his/her competencies. The informants seem to be well aware of the idea of recognising prior learning, as a basis for the project that is also enacted in practice. One participant compared the process to regular schooling:

Here, you really find out about the experiences, what you have. And then you can, so to speak, speed up the pace of an educational programme, you don't need to drag it out over time. In a regular educational programme you need to read through everything. And also do these usual assessment tasks or in other ways show what you know. So for me, this process of recognition of prior learning was really good as you didn't need to read so much. Instead, you can acknowledge what you already know. (Participant 1)

For this participant, the training highlighted her experiences and what she already knew. The idea of estimating one's own knowledge before the teacher designs and carries out the RPL process supports such an interpretation. Participants from two nursing homes described how they were encouraged to make a self-assessment, to estimate their own knowledge in a certain area before the teacher planned how to assess their knowledge, and how to design each module. Thus, the individual's prior experience, learning and knowledge are the starting points for the RPL process.

\section{Discussion as a Main Working Form}

The emphasis on the participant's prior learning and experiences can also be seen in relation to the main working form in this project. Instead of the one-way communication that often seemed to be the norm in regular in-service training at the nursing homes analysed, the focus here was on two-way communication by means of discussion. Almost all the interviewees described how discussions are an important part of recognising the participant's knowledge. Through the discussion, the participants make visible what they already know, which is then assessed by the teacher. But the discussion also means that they are exposed to what others know, something which should be reflected upon in the discussion. Thus, there is also the potential for new learning to take place, as two participants said in an exchange of words:

All the discussions we can have here, and everyone has experiences, and the exchange there. It's not possible to compare with anything else. (Participant 13) 


\section{A. FEJES \& P. ANDERSSON}

It brings together the group that we are, I believe. This is great, you get to know each other. And you view each other in new ways than was previously the case, even if we have worked together for 15 years. You find new good points in the others which you hadn't seen before. And you help each other and ... Yes, this is great. (Participant 12)

Here, we can see a relation constructed between experience, reflection and learning. By discussing certain issues, participants' experiences are reflected upon, which results in new ways of perceiving each other. RPL in this form can thus be seen as both an individual and a collective process of learning in which participants increase their participation in a specific community related to their own nursing homes where they learn from each other's experiences.

By using discussion as the main working method, the participants are encouraged and 'forced' to be active. Thus, there is an emphasis on dialogue and two-way communication as a means of recognising learning and enabling learning to take place, which puts pressure on participants to be active. As two interviewees express this in the following exchange of words:

Now it's about grades, which in some way feels a bit more serious. (Participant 8)

Yeah. Now we could say ... we go to school, yeah, so really that's what we do. And it feels a bit more that one has ... to learn more than in a lecture on how to treat a wound. Of course that's also useful, but it's not...there we haven't been given a task or anything. Here we have a task, therefore one needs to be alert and...it's not enough to just sit here and let the time go by. (Participant 7)

Here, we can see how the work forms used require the participant to be active. The discussions are designed as a way of making everyone active. Having grades and assessment tasks makes the participants feel that this process is more serious than only participating in a lecture every now and then, which is the common format of in-service training at these nursing homes.

However, some of the participants would have preferred more regular schooling where someone lectures. They were probably more used to having someone tell them what is correct or incorrect, as often seemed to be the case in regular inservice training, and they get frustrated when they are the ones to find the solutions. We can find a similar result in Ellström and Ekholm's (2001) study of care workers in the same sector as in our study. According to them, the care workers at one unit were sceptical about a course on quality in care work, in which discussions were the main work form. They had only a vague perception of what the course was about, thus they were hesitant to describe what effects it had. Such problems and frustrations raised by the interviewees are something that can occur when students encounter knowledge that has previously been denied them (or not been available in the contexts they have been active in). Thus, the teacher needs to be able to handle such anxiety (Giroux, 1988). According to Freire (Shor \& Freire, 1987), it is not an easy task to help the students to develop the knowledge that has 
previously been denied them, and the teacher needs to support the students by giving examples through action. However, in our case the focus was on participants' learning from reflection on a problem - problem-solving without any major interference from the teacher.

It follows that discussion as a main working form captures prior learning as an important aspect of the RPL process. Moreover, teachers need to be able to handle the students' anxiety when they encounter knowledge which has previously been denied them. In the next section, we will argue that this process of recognition of prior learning, besides assessing prior learning, also produces new knowledge.

\section{Production of New Knowledge}

Many of the respondents said that the process based on RPL is more substantive than regular in-service training and thus creates a clearer structure. Instead of small pieces every now and then (as claimed in the case of regular in-service training), there is a clear, comprehensive process, which the participant follows. Furthermore, several of the local managers discussed the importance of having a long-term plan for how to create a good in-service training process. One of the managers defined this kind of in-service training as production of knowledge, instead of consumption.

What happens after February [when the program ends]? Will we return to our usual consumption of knowledge ... competence consumption in which we buy something, and that's really good so we show it to others? How can we produce this knowledge here, and make it clear. I think that in some way one can - with guidance, with these techniques, create those moments of reflection, which we often lack. (Manager 6)

Thus, RPL and the method of learning conversations and reflection are seen as things that make the participants produce instead of consume knowledge. We could say that a relation is construed between work experience, reflection, and learning. We have the experiences of all the care workers, and reflecting on them results in production of new knowledge (i.e. new learning).

Thus, the participant's prior learning and experiences are seen as important parts of the recognition process. A relation is also established between experience, learning and recognition, something that will be elaborated on in greater detail in the next section.

\section{Experience and Learning}

Our main interest in this section is the relation between experience, learning, and recognition. The initiative aimed to give recognition to prior learning and to develop new learning through educational activities. However, there is also learning that takes place in the process of assessing prior learning, something which is not accounted for in the interviews, or in prior research on RPL. 


\section{A. FEJES \& P. ANDERSSON}

From constructivist perspectives such as Kolb's (1984), learning is the result of reflected experiences. In this project, the recognition process was to a large extent based on reflection, and such a process is also a process of learning. The participants had much experience from working in elderly care. This experience probably resulted in learning, particularly in instrumental learning, in which they learnt how to do different things in the workplace. One central aspect of the recognition process is that the participants showed that they could do these things, and they got recognition for this. A supervisor emphasised the importance of experience in this specific vocation. She argued that that is what counts, and education is only a complement.

Yes, it's experiential knowledge. We have a lot of that knowledge here ... this work we are doing here, it's experience that counts. That's how it is. And then, education is a complement. (Supervisor 1)

Such experience probably sometimes turned into learning but not always. This latter issue can be related to another aspect, namely, what happens when care workers solve tasks and participate in reflective discussions in the learning conversations? It turns out that the participants had not been used to reflecting on and discussing their work and what they do. Thus the tasks and the conversations not only mean that they made visible what they had learnt previously and got recognition for it, but also that they might turn their prior experiences into knowledge through the learning process of conversation and reflection. In this way, prior learning is a part of the process of in-service training, where it both gets recognition and is a starting point for new learning. But when it comes to prior experience (that has not yet resulted in learning), it is the other way around. Here, it is new learning that becomes a part of the recognition process. Prior experience forms the basis of reflection that results in knowledge, which can then be afforded recognition.

Accordingly, RPL cannot be seen only as recognising prior learning, but also as recognising learning taking place during the assessment process. So even if we have empirically illustrated that prior learning plays a central role in the process, we must also add the new learning that probably takes place. By new learning, we do not only mean learning taking place in those areas where the participants lack knowledge (e.g. medical knowledge which requires additional teaching), but also learning taking place in the assessment process when one's prior experiences are reflected on and questioned. In another quotation, we can see how, according to a supervisor, such questioning of prior assumptions takes place among the participants:

They recognise a bit more, how should I put it ... to think in another way.

You don't have to continue to have this tunnel vision all the time. They have become a bit ... wider in their ways of thinking. (Supervisor 2)

By reflecting on prior experiences and ways of doing work, you might create new assumptions, or revise/discard your old ones. On another level, we could also reflect on the experience of the recognition process per se. This is a new 
experience for the participants, and if/when they engage in reflection on this process, they will learn something about the process of conversation, reflection, and recognition. It could be both instrumental learning, concerning how to reflect and how to behave in a recognition process, and communicative learning, developing the capacity to reflect on and communicate about the experience of participating in this process.

So, it seems that the process of RPL results in new learning, and this learning is part of what is being assessed. Consequently, it is hard to distinguish between prior and new experiences and learning when assessment is carried out. In the final section, we will discuss how the kind of self-reflective techniques used in this programme can also be seen as developing one's capacity for critical thinking, i.e. new learning that is also assessed in the process.

\section{DISCUSSION}

RPL is about identifying, assessing, and documenting a person's prior learning no matter where learning has taken place. In this chapter we have analysed an inservice training programme where care workers' prior learning has been assessed in relation to the health-care programme. The process of recognition of prior learning has been carried out in close relationship between the workplace and an educational provider. Assessment of prior learning has been integrated with additional educational activities. Our aim has been to understand in what ways recognition of prior learning and prior experiences is part of this process of inservice training, and how new learning is an aspect of the process. Thereby, we problematise the relation between experiences, learning, and recognition. In this last section we will particularly discuss the relation between prior and new learning in a training process where the recognition of prior learning is expected to play a significant role. Here, we also highlight issues of power as important matters to discuss.

As the findings illustrate, the participants in the project had much experience from all their years working as care workers. According to the teachers carrying out the assessment, it was possible to identify and assess these experiences in the process of recognition of prior learning. In relation to some of the courses, such assessment has been possible merely by having a couple of group discussions with the participants. Thus, the participants are constructed as people who have prior experience, which also means that they have certain knowledge that can be 'ticked off' on the list of courses, or part of courses, and then added to by means of new learning. However, we have argued that the new learning is not only constructed through the educational processes following the recognition process, but also, through the lens of a constructivist perspective on learning, the recognition process probably produces new learning, which is included in what is being assessed. As found in a study reported by Scott (2007), those with prior experiences from the area might perceive learning even if they already have the relevant knowledge. This must not only be understood in terms of developing different knowledge through practical experience and through an educational process, it must also be 
area might perceive learning even if they already have the relevant knowledge. This must not only be understood in terms of developing different knowledge through practical experience and through an educational process, it must also be understood in terms of learning from experience in the educational process. That is, the reason why the perceived learning among those with experience is higher than expected could be that their experience makes it possible for them to learn more through reflection upon this experience - than those without experience.

From the findings here, it seems that the discussion about RPL needs to include an understanding about what the recognition/assessment process in itself produces. It not only produces a documentation/grade/credential or the ticking off of a course, but it also gives the opportunity for new learning (e.g. the development of care workers' ability to think critically). These issues have, as we illustrated in our overview of previous research, often been neglected. Placing an emphasis on the participants' prior learning and experiences, and using these in the learning and assessment process, is something that could also be beneficial in regular educational activities. In one way, the in-service training presented in this chapter could be seen as adapting 'classical' pedagogical ideals promoted in adult learning theory (cf. Brookfield, 1987; Knowles, 1989; Mezirow, 1991). However, such processes are not without problems. The teacher needs to acknowledge the students' anxiety and frustration when they encounter knowledge that has previously not been available to them (Shor \& Freire, 1987; Giroux, 1988). Thus, it is important to recognise issues of power in such a political practice as care work.

Consequently, issues of power are an important complement to the constructivist theories of learning upon which we base the major part of our analysis. This fact is important as constructivist theories of learning neglect issues of power. For example, Michelson (1996) argues that a focus on reflection about experience is dualistic (body/mind) and that it disregards relations of power. She points to how the process of prior learning assessment makes the body invisible, with reflection and experience being seen as two separate processes - i.e. the reflection of the mind is in the foreground and the bodily experience invisibly present in the background. Similarly, Fenwick (2003) holds that experience and the knowledge-making process (reflection) are construed as two separate elements. She says: 'reflection itself is experienced, and experience as event cannot be separated from our imaginative interpretation and re-interpretation of the event' (ibid., p. 126). Thus, she argues that one cannot separate experience from reflection and knowledge.

We can to some extent agree with this critique since experience, reflection, learning, and knowledge cannot be truly separated - all aspects of the lived experience are integrated in the process of real life. However, different perspectives on experience, learning, and knowledge help us understand different aspects of a process of recognising prior learning. We have employed a constructivist perspective to identify certain aspects of such a process. Our analysis shows how 'classical' ideas of adult education are enacted. Experience, prior learning and new learning interact in a way that is not always the case in the practice of adult education. This and other studies focusing on integrated RPL 
important, not least in times of uncertainty. Credentials and diplomas are part of the formal system that makes mobility and employability easier - particularly in a sector like health care where formal qualifications are central to the system to ensure quality, and the requirements to be employable are strict.

\section{NOTE}

1 This chapter is a revised version of an article by Fejes and Andersson (2009), published in Vocations and Learning, 2(1), 37-55.

\section{REFERENCES}

Andersson, P., Fejes, A., \& Sandberg, F. (2013). Introducing research on recognition of prior learning. International Journal of Lifelong Education, 32(4), 405-411.

Andersson, P., \& Harris, J. (Eds.) (2006). Re-theorising the Recognition of Prior Learning. Leicester: NIACE.

Andersson, P., Sjösten, N.-Å., \& Ahn, S.-E. (2003). Att värdera kunskap, erfarenhet och kompetens: Perspektiv på validering. Stockholm: Myndigheten för skolutveckling.

Brookfield, S. D. (1987). Developing critical thinkers: Challenging adults to explore alternative ways of thinking and acting. San Francisco, CA: Jossey-Bass.

Ellström, E., \& Ekholm, B. (2001). Lärande $i$ omsorgsarbete: En studie av hemtjänsten som lärandemiljö. Linköping: Linköping University, CMTO research monographs, NO 1.

Evans, N. (Ed.). (2000). Experiential learning around the world: Employability and the global economy. London: Jessica Kingsley.

Fejes, A., \& Andersson, P. (2009). Recognising prior learning: Understanding the relations among experience, learning and recognition from a constructivist perspective. Vocations and Learning, 2(1), 37-55.

Fenwick, T. (2003). Reclaiming and re-embodying experiential learning through complexity science. Studies in the Education of Adults, 35(2), 123-141.

Giroux, H. A. (1988). Teachers as intellectuals: Toward a critical pedagogy of learning. Massachusetts: Bergin \& Garvey.

Harris, J., Breier, M., \& Wihak, C. (Eds.). (2011). Researching the recognition of prior learning: International perspectives. Leicester: NIACE.

Harris, J., Wihak, C., \& van Kleef, J. (Eds.). (2014). Handbook of the recognition of prior learning: Research into Practice. Leicester: NIACE.

Kolb, D. (1984). Experiential learning: Experience as the source of learning and development. Englewood Cliffs: Prentice-Hall.

Kvale, S. (1996). Interviews: An introduction to qualitative research interviewing. Thousand Oaks, CA: Sage.

Knowles, M. (1989). The making of an adult educator. San Francisco, CA: Jossey-Bass.

Mezirow, J. (1991). Transformative dimensions of adult learning. San Francisco, CA: Jossey-Bass.

Michelson, E. (1996). Beyond Galileo's telescope: Situated knowledge and the assessment of experiential learning. Adult Education Quarterly, 46(4), 185-195.

Scott, I. (2007). Accreditation of prior learning in pre-registration nursing programmes: Throwing the baby out with the bath water? Nurse Education Today, 27(4), 348-356.

Shor, I., \& Freire, P. (1987). A pedagogy for liberation: Dialogues on transforming education. Massachusetts: Bergin \& Garvey.

Somerville, M. (2006). Becoming-worker: vocational training for workers in aged care. Journal of Vocational Education and Training, 54(4), 471-481.

Step for skills. (2007). SOU 2007:88: Att lära nära: Stöd till kommuner för verksamhetsnära kompetensutveckling inom omsorg och vård av äldre. Stockholm: Regeringskansliet. 
FEJES AND ANDERSSON

Andreas Fejes

Department of Behavioural Sciences and Learning

Linköping University, Sweden

Per Andersson

Department of Behavioural Sciences and Learning

Linköping University, Sweden 
PART 3

MACRO LEVEL OF WORKING AND LEARNING 



\section{CHALLENGES FOR WORK-BASED LEARNING IN VOCATIONAL EDUCATION AND TRAINING IN THE NORDIC COUNTRIES}

\section{INTRODUCTION}

Systems of vocational education and training (VET) that include periods of workbased learning have many attractive qualities, seen from a political perspective. VET systems that build on the tradition of apprenticeship with alternating training provide a valuable alternative for young people who chose not to pursue an academic career. Countries with strong apprenticeship systems tend to have lower youth unemployment and a smoother transition to the labour market than countries with school-based VET. Furthermore, from a learning perspective, the outcomes of work-based training are enhanced when they are combined with formal education in a dual system.

In all the Nordic Countries full time work-based apprenticeship has given way to more school-based forms of VET - though to very different extent. In Sweden VET has gradually from the early 1970 ies been integrated into the comprehensive Gymnasium, and apprenticeship only survives as post-secondary programmes in a few industries (Olofsson, 2005). Also in Finland full time school-based VET has become dominant, while apprenticeship remains as a small programme mainly for adults (Stenström \& Virolainen, 2014). In Denmark a dual system has been maintained in a more classical form, where two thirds of the vocational programmes are work-based training. Norway represents a combined model (the ' $2+2$ model') where two years of school-based courses precedes two years of work-based training.

Despite these differences in all the Nordic Countries we have seen a growing political interest in promoting apprenticeship and work-based learning in VET similar to what is the case in other European countries (Cedefop, 2014). However, these intentions have often run into serious difficulties, and even established apprenticeship programmes have encountered difficulties integrating work-based learning. These difficulties include access to training placements, the quality of training and the image that apprenticeships have among young people and in the labour market (Fuller \& Unwin, 2009; Schaap et al., 2012).

This chapter will examine these challenges that question the future role of workbased training in VET. The analyses and discussions are based mainly on the Danish dual system of VET and on comparisons of this system with other Nordic 


\section{H. JØRGENSEN}

Countries. In the end innovative solutions to these challenges are discussed and experiences from other European countries are examined.

\section{METHODOLOGY}

The analyses of the qualities of work-based and school-based learning in this chapter are based on several studies in which the author has participated. The first was a study 'The future of Vocational Education' supported by the trade union federation in Denmark (LO) to investigate the problems and prospects of learning in training placements in VET (Jørgensen et al., 2006). In this study a review of literature was made and qualitative interviews with managers in 200 companies and with nine policy makers in four occupations were conducted. The study focussed on companies authorised to train apprentices, but not currently employing any apprentice to explore the reasons why they were not training at the time. The four occupations were selected to represent diversity in the nature of work and the conditions for companies: bricklayers, automation technicians, clerks and care workers.

The second study examined the quality of full time school-based training scheme in the Danish vocational education (Jørgensen \& Juul, 2010). The study combined a quantitative examination of the labour market career of all students in this scheme three years after completing a vocational programme. In addition, it included individual interviews with 25 students and 20 teachers and policy makers in VET to examine the strengths and weaknesses of the school-based training scheme. The scheme was introduced in 1993 to compensate for lack of ordinary training placements, but has had a marginal role in Danish VET. In connection with this project, we made a literature review to explore alternative ways of organising workplace training in VET in Europe.

Lastly, this chapter draws on a current research project ${ }^{1}$ comparing VET in four Nordic Countries with a special focus on the relation between work-based and school-based education in the VET programmes (www.nord-VET.dk). The first part of the project traces the historical emergence of VET, and this study has revealed a great diversity of driving forces behind the growth of school-based learning in VET at the expense of work-based training.

\section{THEORETICAL INSPIRATION}

The theoretical point of departure for this article is firstly research on workplace learning, which has grown significantly the last two decades (Billett \& Choy, 2013; Hager, 2011; Rauner, 2004). This research has brought out the rich potentials of work as a learning environment, but also the limited opportunities for learning in Taylorist regimes of work. Secondly comparative research in the social embeddedness of VET has exposed the diverse forms of institutional architecture that regulate the relationship between school-based and work-based learning in European countries (Ashton, 2004; Thelen, 2004; Greinert, 1999; Deissinger, 1998). Comparative education research often operates with three ideal-typical 
regimes, each with its own form of governance, namely, market-based, state-based and neo-corporatist governance (also known as occupational self-governance). The VET systems in the Nordic Countries combine different aspect of all the three regime types, predominantly the last two mentioned. In the following some of the differences in the role of work-based training in each regime will be described.

In a market-led regime, the role of the state is limited to ensuring the general skills, and both the labour market organisations and the state play a limited role in the regulation of the labour market. The absence of institutionalised regulation has historically contributed to the weakening of apprenticeship system under this regime (Thelen, 2004). For apprentices there is no statutory requirement to enter into a contract to regulate the duration or content of the training in the companies or to ensure other rights of the young people (Steedman, 2012). In this regime, learning in the workplace is subject to the individual companies' specific requirements for skills and their short-term economic interests. The skills that are developed through this form of learning in the workplace are not certified and are therefore less portable. Skills have limited value in the open labour market because mostly they are narrow and company-specific. The consequences of market regulation are that the school-based and work-based learning are organised as two separate activities with little coherence, divided into 'education' and 'training' respectively (Finegold \& Soskice, 1988). In the Nordic VET systems the role of the market has been limited, but it is the dominant regulatory mechanism for the distribution of training placements in Denmark.

In regimes based on state-led governance, the state undertook the task of organising vocational education and training in the period after the industrial revolution and the dissolution of the guilds (Green, 1995). Vocational education and training was gradually integrated into the general education system and converted into school-based vocational education and training, where the general and theoretical subjects are dominant (Greinert, 1999). There may be short training periods included, but the students do not receive wages during their training placement. The students are not formally employed, but are subject to the control of the school. In the Swedish version of this model of VET, major emphasis was placed on democratic citizenship and on providing all young people with access to higher education. In this model, the training of young people in the workplace was largely left to the companies themselves, which means that there was little assurance of the quality and breadth of the workplace tuition. Often, this model entails a 'practice shock' for young people when they move from the education system into the labour market, compared with the transition from an alternating education. This regime is associated with higher rates of youth unemployment, due to the gap between the world of education and the world of work, and because the companies must bear the costs of training young people who earn higher wages than apprentices' wages.

In the third regime, it is neither the individual companies nor the state, but the organisations in the labour market that are the primary stakeholders in the form of occupational self-governance of VET. In the Danish case, this self-governance is exercised by institutionalised cooperation between the social partners and the state 


\section{H. JØRGENSEN}

(neo-corporatism), which limits the opportunities for individual companies to operate outside the cooperation system ('free riders'). It is within this regime that apprenticeships based on the dual system have been particularly successful. A key quality in this regime is that work-based learning aims to teach the apprentices an occupation, which integrates theoretical and practical knowledge (Deißinger, 1998). Apprentices are employed in the company and receive wages that are regulated by the social partners. They are socialised into the occupational culture by engaging in the work and in the professional communities in the workplace (Heins, 1995). VET systems based on the dual system promote broad job profiles in the companies with a high degree of autonomy, a limited hierarchy and a high degree of functional flexibility (Deißinger, 1998). The strong involvement of the labour market partners means that the vocational training is strongly oriented towards the skills that are currently in demand in the labour market. Many of the companies who employ apprentices do so in order to recruit them afterwards. In Denmark, this means that about half of the apprentices are subsequently employed in the company in which they were trained.

These three skills regimes are ideal types, which do not exist anywhere in their pure form, but they illustrate three very different types of institutional architecture around the interaction between workplace learning and learning at school. In all three regimes, there has historically been a move away from the apprenticeship's purely work-based learning, towards an expansion of school-based forms of vocational education and training. This is due to a number of advantages associated with learning in a school context.

\section{EXPANSION OF SCHOOL-BASED VOCATIONAL EDUCATION AND TRAINING}

Based on studies of the Danish vocational education programmes, a number of driving forces can be identified that are responsible for the spread of school-based vocational education and training (Jørgensen et al., 2006; Jørgensen \& Juul, 2010). The first schools aiming at apprentices in the early 19 century had as the main aim to offer basic skills in reading, writing and math to compensate for the poor quality of the public schools. Secondly, with the advent of industrial capitalism changes in the technical organisation of work, associated with first mechanisation and later automation and computerisation gave rise to demands for more theoretical knowledge in apprenticeship. In Denmark, this led in the late 1800 s to the establishment of evening classes for apprentices at the initiative of masters and craft associations. Legislation in the 1930s provided the possibility of introducing day schools to ensure the quality of skilled workers (Bøndergaard, 2014). A third driving force behind the shift towards vocational schools was the scarcity of training placements for apprentices. This became clear when the large youth cohorts ('baby boomers') entered the labour market in the 1950es. In order to compensate for the lack of apprenticeship places, a reform in 1956 established mandatory full-day schools for all occupations, so that the tradition apprenticeship system was transformed into a system based on alternating training (Juul \& Jørgensen, 2011). Later, in the 1980s, the shortage of training placements resulted 
in the introduction of a full time school-based vocational programme. This programme has expanded since the financial crisis in 2008 and currently caters to around $10 \%$ of all students in vocational education.

A fourth driving force behind the increase in the school-based part of vocational education and training in Denmark was the labour movement's demand that young people in vocational training should be trained for active citizenship, similarly to the young people in upper secondary education. These political motives were particularly strong in connection with the reform in 1977, and they led to the introduction of a one-year, school-based basic course in all vocational programmes. At that time, powerful forces in Denmark pursued a 'Swedish solution' with an integrated upper secondary comprehensive school system which did not materialise however.

As a fifth driver, the demand for flexibility in the education system and mobility in the labour market has been an argument for increasing the content of general subjects in vocational education. A broader theoretical knowledge should make it easier for young people to switch to another education later in life and to continue in higher education. Yet another driver for increasing the role of vocational schools is that businesses are becoming increasingly specialised. Consequently, vocational schools should have a stronger role in VET to offer the whole range of broad vocational qualifications. In addition, it has been argued that apprentices are being exploited and that the quality of company-based training is too low. In Sweden and Finland this has been a central argument forwarded by the labour organisations for shifting towards school-based training (Olofsson \& Thunqvist, 2013; Kivinen \& Peltomäki, 1999).

To sum up, through history a wide range of reasons for expanding school-based VET has been put forward. First of all, in a school, the students' learning is not subject to the requirements of production and economic interests of the training company. The students therefore have better opportunities to reflect on their work and learn from their mistakes. The school-based vocational education and training is also better equipped to ensure that the students learn all of the skills of their craft, since businesses are often more specialised. The training in a school can be organised according to the student's learning needs, without regard to the company's production needs. In a workplace, there is a risk that the apprentices are primarily used as cheap labour and are assigned to routine tasks for extended periods.

School-based education can be particularly advantageous for the very young or vulnerable students, who need to build up a professional self-confidence before starting on an ordinary company training programme. The teachers in the schoolbased vocational education and training can be more socially inclusive than companies. Finally, the capacity of the school-based vocational education and training is not dependent on business cycles which influence the number of training placements offered by companies. With school-based vocational education programmes, the state can meet future labour market needs for skilled workers, regardless of fluctuations in the market for training placements. Despite the many benefits of full-time school-based vocational education programmes, they also 


\section{H. JØRGENSEN}

have some weaknesses in comparison with alternating training. Some of these weaknesses were described earlier in relation to the state-led regime of VET. School-based systems of VET under state control are separated from the world of work and create greater difficulties for students' transition to the labour market. In a school-based system young people who have become alienated from school have no alternative progression routes after leaving compulsory school. In addition, many competences can better be learned in a work context than at school (Hager, 2011).

\section{BENEFITS OF ALTERNATING TRAINING}

There are many benefits of alternating training which combine school-based and work-based learning. One benefit is lower rates of unemployment among young people when they enter the labour market (Müller, 2005; Wolbers, 2007). The Danish dual system is often accredited for the lower rate of youth unemployment compared to Sweden or the UK (Olofsson \& Wadensjö, 2012; Dieckhoff, 2008). When young people in Denmark complete apprenticeship and get a job, they have almost the same level of unemployment and wages as skilled employees with long work experience.

At the same time, apprenticeships offer an attractive route to the labour market for many young people who are not aiming for a higher education. Comparative studies have shown that a separate track with work-based vocational education provides a safety net for those who do not thrive in an academic learning environment (Wolbers, 2007; Müller, 2005). In Denmark and the German-speaking countries, apprenticeship is recognised as an alternative pathway with its own qualities which are different from the academic track. In this respect Denmark is closest to the neo-corporatist regime while Finland and Sweden, with their integrated systems of upper secondary education, lie closer to the state-led regime of VET.

Organising VET as a separate system with a high degree of employers influence and with close links to the labour market stimulates companies' willingness to offer apprenticeships. Giving employers a strong sense of 'ownership' of VET is difficult to reconcile with the strong state control exercised in relation to the academically oriented general educations. Apprenticeship systems are therefore most often organised with some form of occupational self-governance of VET and as a separate system that is not integrated with general upper secondary educations (Steedman, 2012).

The downside of the division into two tracks, one academic and one vocational, is that the apprenticeships have weak links to higher education, and thus appear as a 'dead end,' as is the case in Denmark (Jørgensen, 2013a). Given the social inequalities in the recruitment to the vocational education, this means that a large group of youth from families with low levels of education are diverted from higher education when they start up in an apprenticeship. In contrast, all vocational programmes in Sweden aim to give eligibility for higher education (Dobbins \& Busemeyer, 2014). 
Another advantage of apprenticeships is the close match between education and the labour market. This ensures that the skills gained during the education are relevant and useful in the labour market. In a comparison between the United States and Germany, Szydlik (2002) has shown that young people with an apprenticeship in Germany have a much better chance of using their skills than similar young people in a school-based vocational education in the United States. This means that a larger share of graduates in the United States work in jobs where they do not utilise their education (under-employment). Müller (2005) and Dieckhoff (2008) have similarly shown that the chances of a person with a completed vocational education for obtaining skilled employment are greater in Germany than in the United Kingdom. Similarly, the risk of ending up in an unskilled job is correspondingly lower in Germany. This can be explained by the fact that an apprenticeship provides direct access to an occupational labour market that is both well-defined and recognised by the social partners (Müller, 2005).

A third advantage is the high mobility and flexibility that apprenticeships create in connection with occupational labour markets. This can be clearly seen in Denmark which holds the record within the EU for labour mobility between firms. This is the result of three characteristics of apprenticeships: the strong national certification of the education programmes' skills profiles, the education programmes' occupational profiles and the labour market partners' ownership of the programmes as a result of the occupational self-governance.

A fourth advantage of apprenticeships is that they are better than school-based programmes at providing opportunities for the development of a strong occupational identity, especially during the workplace-based learning (Heins, 1995; Jørgensen, 2013b). While school-based vocational education and training provides an identity as a pupil or a student, apprenticeships provide access to recognised adult worker identities and to participate in work practices that young people can experience as meaningful. The training placement allows students to experience self-esteem through participation in authentic work tasks that have value for colleagues, customers and clients, and to achieve a social affiliation in an occupational community. Developing a strong professional identity is also important for society, because it develops collective norms for quality in work, which help to ensure standards of quality in work through the professions' internal regulation and the individual's professional pride. There are many benefits that derive from alternating training, therefore, but they are also facing a number of challenges, which we will discuss in the next section.

\section{CHALLENGES FOR ALTERNATING TRAINING}

In the history of VET in the Nordic Countries it has often been questioned whether companies can offer qualified training, when the main aim of companies is to make economic profit. The abolition of the traditional apprenticeship systems in both Sweden and Denmark occurred after intense criticism of the fact that the apprentices were used as cheap labour and that they learned too little (Olofsson \& Wadensjö, 2012; Bøndergaard, 2014). In Denmark, there is little monitoring of 


\section{H. JØRGENSEN}

workplace learning and there is no requirement for formal teaching skills for the workplace trainers. The reason why no more is done to ensure the quality of the workplace training is primarily the fear that companies will respond by reducing the supply of training placements in a situation where there is already a shortage. A number of other changes in the workplace have been identified that raise questions regarding work-based training (Jørgensen et al., 2006).

Probably the biggest challenge for alternating training is the recurrent shortage of training placements. In particular, the cyclical shortage of apprenticeships leads to a reduction in training capacity during economic downturns, which can increase the shortage of skilled labour when the economy recovers. This weakness means that, in many countries, workplace training is supplemented with school-based vocational education (Jørgensen \& Juul, 2010). Another problem is a structural shortage of apprenticeships that we see in some industries as a result of technological, economic and organisational changes. A shift is taking place from old industrial and craft industries to new service industries that do not always have a tradition for training apprentices and providing training placements. It can be difficult to establish a tradition of employing apprentices and skilled workers in industries such as retail, which often employs unskilled and semiskilled workers. In addition, technological changes with automation and computerisation mean that increasing investments are needed to establish a workplace - or a training placement. Secondly, the employee's contact with the production process is becoming more indirect and occurs through screens and symbols. This means that higher levels of specialised theoretical knowledge are required in order to gain access to the learning environments in the workplace, and this may restrict the capacity of companies to train young people directly in the production process.

Thirdly, many companies have introduced new organisational principles with short delivery times (just-in-time), quality assurance and 'sero-error production,' which means there are fewer opportunities for young people to directly engage in production and learn by experimenting, testing their skills and learning from their mistakes.

Fourthly, production is becoming increasingly specialised, which means that each company is less able to offer training in all the vocational qualifications required to learn an occupation. When talking about specialisation, therefore, we should distinguish between the companies' specialisation and the specialisation of the jobs and the work tasks, because the two levels often develop in opposite directions. Today, in Denmark it is typical that there is a specialisation of companies and a de-specialisation of jobs and employees. The overall result of these two changes can be both that there are fewer opportunities and that there are better opportunities for a broad, professional training.

Fifthly, deregulation has entailed that the short-term speculative financial markets have acquired increased importance for businesses, with a shift from a 'stakeholder' to a 'shareholder' economy (Green, 2006). The companies are increasingly forced to adopt a short-term, 'bottom-line' approach because they are assessed based on their financial returns for investors, rather than their long-term 
contribution to society. This means that the companies have less ability to make long-term investments to secure a skilled workforce for the future by training apprentices.

Sixthly, training placements have a built-in duality: they are simultaneously both an education and work. It is of major importance for the apprentices that they can be included in authentic work processes in collaboration with experienced craftsmen and that they create something of value for others. However, young people also have high expectations of being allocated interesting and challenging tasks to learn from. The duality appears increasingly as a conflict between the expectations of the apprentices and those of the companies. For many apprentices, the apprenticeship is primarily a part of an education programme, while the company regards it primarily as an employment relationship. This conflict of interest has always been a part of the training placement, with complaints from apprentices that they were used as cheap labour, and complaints from businesses about the apprentices not being productive enough. There are signs that this duality is becoming more antagonistic, because the companies and the apprentices are drawing further apart. The companies are increasingly requiring that apprentices should be self-managing and contribute to the production process in a more focused and qualified manner, i.e. that they should be effective as workers. The apprentices, on the other hand, are increasingly demanding that their training placement should be more focused on contributing to their personal skills development and to their education. This conflict is one of the reasons that, over the past 10 years, one in five apprentices in Denmark has terminated their apprenticeship contract before completion. A solution to this problem may be that the training placement could shift status to being only education and not work, as has happened in a number of the welfare professions (like teachers and nurses). In the case of nurses, wages have been replaced by state grants and the training placement is redefined as 'clinical teaching.' This may result in the students feeling that the training placement has lost some of the socialising and motivational qualities that are associated with it being 'real work.'

As already mentioned, a weakness of dual systems in Denmark and Germany is that the strong separation between academic and vocational programmes reinforces social inequality in the education system (Müller, 2005). The social inequalities in the recruitment to vocational education and training also contribute to reducing the esteem of vocational education. The declining social esteem of vocational education is a challenge, which is associated with the fact that education systems with an early separation in two tracks involve strong social selection. It is a problem that alternating training programmes, like the Danish dual system, restrict social mobility, because they bar the way to higher education for young people who take a vocational education (Jørgensen, 2013a). However, this negative effect depends on the status that apprenticeships have compared to school-based vocational educations and academic preparatory educations. The new apprenticeship programmes in Sweden from 2011 have not achieved a high status (Swedish Schools Inspectorate, 2013), while the apprenticeship programmes in 


\section{H. JØRGENSEN}

Germany and Switzerland have retained a high status among both young people and the labour market.

\section{THE FUTURE OF WORK-BASED LEARNING IN VET}

The future for alternating training programmes level depends on whether they can cope with two major challenges: providing access to training placements of high quality and providing access to higher education. In Denmark, these challenges are the reason why vocational education and training lost status among young people in recent decades, where an increasing number of young people choose the academic programmes instead of vocational educations. There is evidence here for a self-reinforcing process, where the declining esteem entails that the vocational educations only recruit students with few resources and negative experiences from primary school. This may exacerbate the social inequalities in recruitment patterns and the declining status.

There are several possibilities to address the major challenges with regard to training placements. Experience from Norway shows how a strong tradition for occupational self-governance can achieve a collective solution, where the labour market partners work with the state and the schools to assume responsibility for providing training placements. The Norwegian training offices are an example of an institutional innovation that organises collective skills formation at a local level, across individual companies. The training offices (also called training rings) are organised by a network of companies. They address the joint and long-term interest that the companies have in ensuring an adequate supply of skilled labour of high quality (Bowman, 2005). Their responsibilities include ensuring that there are training placements that correspond to the needs of the labour market and the demands of young people. Two thirds of training placements in Norway are allocated through the training offices. It is also their task to improve the quality of the training and to distribute the apprentices to the companies (Høst, 2014). This is a solution whereby the companies, both collectively and in collaboration with the schools, coordinate the distribution of students and training placements. This is a reinvention of corporatist cooperation at the local level. A weakness, however, is that trade unions are only marginally involved in this collaboration, similar to the German 'Kammern' (chambers) (Deissinger 1998).

New institutions known as Training Centres [praktikcentre] were established in Denmark in mid-2013. Their task is to coordinate the companies' supply of apprenticeships, including those of short duration, with students who are looking for training placements. The position of the 50 Danish training centres in the institutional architecture resembles that of the Norwegian training offices, but they were established at the initiative of the state and under the auspices of the vocational schools. The training centres also organise school-based training in workshops under conditions similar to working in a workplace. This gives them a role as a 'third learning environment' between school and the workplace that tries to combine the best features of school-based and work-based learning. The vocational education and training programmes in Switzerland have been 
experimenting for many years with the development of a 'third learning environment,' which partly can compensate for weaknesses in both the school and the apprenticeship system, and which can also help to connect the two other learning environments (Goetse et al., 2002). A similar experiment was conducted in Denmark at a vocational school under the name 'Praktikum,' which was later implemented in the painters' education (Koch \& Lundgaard, 2005). A Praktikum placement is a separate learning environment between the school and the company, where students, under the guidance of teachers, can combine theory and practice while working to solve development problems which are drawn from the workplace.

A third interesting innovation comes from the Swiss training association (Lehrbetriebsverbund), which consists of a number of companies that supplement each other in terms of the tasks and qualifications they can offer the apprentices (Imdorf \& Leemann, 2012). In this way, even very specialised companies can contribute to maintaining a wide range of training placements within recognised vocational educations. The student enters into a contract with the main company, which then enters into agreements with the other companies. There may also be external partners associated (such as a college or a trade association) that perform the administrative tasks of planning, coordination and support for the companies and the work of integrating new companies into the association. The student has a permanent contact person from the responsible company throughout the entire process. The training association gives companies greater flexibility in terms of how long a period they undertake to train the students (Imdorf \& Leemann, 2012). The students receive a more comprehensive training by alternating between several specialised companies and apprenticeships are established in companies that are too specialised to recruit apprentices on their own.

The second challenge for the apprenticeship programmes is to provide access to higher education, so that they do not appear to be a 'dead end' in the education system. There are interesting experiences from several places in this regard. In Switzerland, there has been a hybrid vocational programme since 1993, 'Berufsmaturität,' Norway has developed the 'Technical General Subjects' [Tekniske Allmenne Fag] which combine the skilled workers' qualifications with entrance qualifications for higher education. Similarly, a new hybrid education was started in Denmark in 2011, eux, which combines the two types of qualifications. The major innovations are found when there is success, not only in combining, but also in integrating the two types of qualifications into a coherent learning process (Jørgensen, 2013a). The challenge with these innovative programmes is to avoid that they become only an offer for the most ambitious young people, as the study requirements are quite high.

The conclusion, therefore, is that although alternating training has many advantages, there is also a need for innovation to tackle a number of significant challenges analysed above. A good source of inspiration can be found in studies of reforms of vocational education and training in other countries. The Nordic Countries have developed quite divergent systems of VET and are all experimenting with new ways of combining work-based learning with eligibility 


\section{H. JØRGENSEN}

for higher education in the vocational programmes. Due to their cultural and political similarities these countries have an unexploited potential for mutual policy learning - with respect for the specific conditions in each VET system.

\section{NOTE}

1 This chapter is based on a Nordic research project Nord-VET - The future of Vocational Education in the Nordic Countries supported by the NordForsk programme "Education for Tomorrow," Homepage: http://nord-vet.dk

\section{REFERENCES}

Ashton, D. (2004). The political economy of workplace learning. In H. Rainbird, A. Fuller, \& A. Munro (Eds.), Workplace learning in context. London: Routledge.

Billett, S., \& Choy, S. (2013). Learning through work: Emerging perspectives and new challenges. Journal of Workplace Learning, 25(4), 264-276.

Bøndergaard, G. (2014). The historical emergence of the key challenges for the future of VET in Denmark. Research report, Roskilde University. www.Nord-VET.dk

Cedefop (2014). Developing apprenticeships. Briefing note 9088 EN. Thessaloniki, CEDEFOP.

Deissinger, T. (1998). Beruflichkeit als "organisierendes Prinsip" der deutschen Berufsausbildung. Markt Schwaben: Eusl Verlag.

Dieckhoff, M. (2008). Skills and occupational attainment: A comparative study of Germany, Denmark and the UK. Work, Employment \& Society, 22(1), 89-108.

Dobbins, M., \& Busemeyer, M. R. (2014). Socio-economic institutions, organised interests and partisan politics. Socio-Economic Review, 12(4), 1-32.

Finegold, D., \& Soskice, D. (1988). The failure of training in Britain: Analysis and prescription. Oxford Review of Economic Policy, 4(3), 21-53.

Fuller, A., \& Unwin, L. (2009). Change and continuity in apprenticeship: The resilience of a model of learning. Journal of Education and Work, 22(5), 405-416.

Goetse, W., Gonon, P., Gresele, A., Kübler, S., Landolt, H., Landwehr, N., \& Egger, P. (2002). Der dritte Lernort. Bildung für die Praxis, Praxis für die Bildung. Bern: hep-Verlag.

Green, A. (1995). Technical education and state formation in nineteenth-century England and France. History of Education, 24(2), 123-139.

Green, A. (2006). Models of lifelong learning and the 'knowledge society.' Compare, 36(3), 307-325.

Greinert, W.-D. (1999). Berufsqualifisierung und dritte industrielle Revolution. Baden-Baden: NomosVerlags-Gesellschaft.

Heins, W.R. (1995). Arbeit, Beruf und Lebenslauf. München: Juventa.

Hager, P. (2011). Theories of workplace learning. In M. Malloch, L. Cairns, K. Evans, \& B. N. O'Connor (Eds.), The Sage handbook of workplace learning (pp. 17-31). London: Sage.

Høst, H. (Ed.). (2014). Kvalitet i fag- og yrkesopplceringen. Fokus på opplceringen i bedrift. Oslo: NIFU.

Imdorf, C., \& Leemann, R. J. (2012). New models of apprenticeship and equal employment opportunity. Do training networks enhance fair hiring practices? Journal of Vocational Education \& Training, 64(1), 57-74.

Juul, I., \& Jørgensen, C. H. (2011). Challenges for the dual system and the occupational self-governance in Denmark. Journal of Vocational Education and Training, 63(3), 289-303. 
Jørgensen, C. H. (2013a). Linking the dual system with higher education in Denmark - When strength becomes weakness. In T. Deissinger, J. Aff, A. Fuller, \& C. H. Jørgensen (Eds.), Hybrid qualifications (pp. 53-78). Bern: Peter Lang.

Jørgensen, C. H. (2013b). The role and meaning of vocations in the transition from education to work. International Journal of Training Research, 11(2), 167-184.

Jørgensen, C. H., Jensen, H. H., Larsen, L., \& Hansen, J. A. (2006). Hvorfor oprettes der ikke praktikpladser? Øje på Uddannelse, København: Landsorganisationen i Danmark.

Jørgensen, C. H., \& Juul, I. (2010). Bedre samspil mellem skolepraktik og ordincer virksomhedspraktik. Roskilde Universitet og Undervisningsministeriet. http://www.uvm.dk/

Kivinen, O., \& Peltomäki, M. (1999) On the job or in the classroom? The apprenticeship in Finland from the 17th century to the 1990s. Journal of Education and Work, 12(1), 75-93.

Koch, H. H., \& Lundsgaard, S. (2005). Praktikum i praksis - aktivering af skole-virksomhedssamspillet. København: Undervisningsministeriet.

Müller, W. (2005). Education and youth integration into European labour markets. International Journal of Comparative Sociology, 46(5-6), 461-485.

Olofsson, J., \& Thunqvist, D. P. (2014). The Swedish model of vocational education and training: Establishment, recent changes and future challenges. Research Report, Linköping and Malmö Universities: Nord-VET, http://nord-vet.dk

Olofsson, J., \& Wadensjö, E. (2012), Svensk lärlingsutbildning - förutsättningar och utmaningar. In H. Håkon (Ed.), Tradisjonelle utfordringer - fornyet intresse (pp. 101-123). TemaNord, 2012:50. København: Nordisk Ministerråd.

Rauner, F. (2004). Die arbeitsorientierte Wende in der Didaktik beruflicher Bildung. In A. Busian, G. Drees, \& M. Lang (Eds.), Mensch, Bildung, Beruf. Herausforderungen an die Berufspädagogik (pp. 273-283). Bochum; Freiburg: Projekt Verlag.

Schaap, H., Baartman, L., \& de Bruijn, E. (2012). Students' learning processes during school-based learning and workplace learning in vocational education: A review. Vocations and Learning, 5(2), 99-117.

Steedman, H. (2012). Overview of apprenticeship systems and issues. International Labour Office, Skills and Employability Department, Geneva: ILO.

Stenström, M-J., \& Virolainen, M. (2014). The history of Finnish vocational education and training. University of Jyväskylä. www.nord-vet.dk

Szydlik, M. (2002). Vocational education and labour markets in deregulated, flexibly coordinated and planned societies. European Societies, 4(1), 79-105.

Thelen, K. (2004). How institutions evolve: The political economy of skills in Germany, Britain, the United States and Japan. Cambridge: Cambridge University Press.

Wolbers, M. H. J. (2007). Patterns of labour market entry. A comparative perspective on school-to-work transitions in 11 European countries. Acta Sociologica, 50(3), 189-210.

\author{
Christian Helms Jørgensen \\ Department of Psychology and Educational Studies \\ Roskilde University, Denmark
}





\author{
TORGEIR NYEN, ASGEIR SKÅLHOLT AND \\ ANNA HAGEN TØNDER
}

\title{
13. VOCATIONAL EDUCATION AND SCHOOL TO WORK TRANSITIONS IN NORWAY
}

\begin{abstract}
INTRODUCTION
In times of globalisation the deregulation of labour markets and restructuring of work have created challenges in European labour markets in general and in youth labour markets in particular. Increased international competition has led to more uncertainty about the future development of the labour market, making transitions from youth to adulthood more complex. Educational attainment is often emphasised as a necessary condition for the integration of young people in the labour market. But as research on transitions from school to work has demonstrated, the specific role of education in labour market integration varies according to structural and institutional factors that shape supply and demand for specific qualifications (Aarum \& Shavit, 1995; Müller \& Shavit, 1998). In addition to variation between different institutional contexts, transition patterns from school to work also change over time. Young people tend to spend an increasing number of years in the education system before entering into more or less stable jobs. The number of possible routes towards the labour market has expanded rapidly during recent years, making transitions less transparent and more demanding for young people. Transitions have become both longer and more complex (Heinz, 2002; Müller \& Gangl, 2003). Young people tend to move back and forth between the labour market and the educational system, they skip from one educational path to another, or they leave the education system entirely without ever completing a formal education.

A number of political reforms has been initiated aiming to ease school to work transitions for young people by improving educational attainment. Dual systems and apprenticeship training have often been associated with low levels of youth unemployment (Steedman, 2012). The provision of specific occupational skills and the gradual socialisation to work during apprenticeship training are mechanisms that are considered to facilitate labour market integration for young people (Jørgensen, 2013). However, changes in occupational structures may lead to changes in labour market opportunities for skilled workers. These changes may affect school to work transitions in different ways in different countries and labour market segments, and they may also affect different social groups in different ways (Smith, 2009).
\end{abstract}


In this chapter we analyse current patterns of transition from school to work in the Norwegian VET model. The emphasis is on variation in transition patterns in different vocational programs in upper secondary education. The main questions asked are to what extent vocational education and training gives access to work and how transition patterns for VET graduates vary between different parts of the Norwegian labour market.

\section{VOCATIONAL EDUCATION AND TRAINING IN NORWAY}

In 1972-1987, the average youth unemployment rate in Norway was relatively low, at around 6 per cent. After 1987 there was a sharp increase in youth unemployment to an average level of 11 per cent in 1987-2005 (Barth \& von Simson, 2012). An increasing number of young people outside of work and education was an important background for the introduction of a reform of upper secondary education in Norway 1994 (Reform 94). The reform granted 16-19 year olds a statutory right to three years of upper secondary education. Students could choose between three general academic programs and twelve vocational programs in upper secondary education. Before Reform 94, apprenticeship training had played a quite moderate role in Norway, with a limited number of apprenticeship contracts being signed every year, mainly within crafts and parts of the industry. In the 1970s, only 2-3000 new apprenticeship contracts were signed every year. Employers often preferred older youth or young adults when they recruited apprentices, making it difficult for young persons to find apprenticeship positions (Høst, Michelsen \& Gitlesen, 2008). The capacity in vocational schools was limited. Many students were moving horizontally between vocational programs, and progression was low. With Reform 94, apprenticeship training became an integrated part of the formal education system.

The main model in vocational training after the reform is the so-called $2+2$ model, combining two years of school based training with a two year period of apprenticeship training. The implementation of the reform, which was supported by employers' organisations and trade unions, required a significant increase in the number of training companies and apprenticeship positions. The intention was that one third of a youth cohort would follow the $2+2$ model and complete upper secondary education with a trade or journeyman's certificate. A number of new trades was established in sectors without strong traditions for apprenticeship training, including the municipal sector and the private service sector. The expansion of the apprenticeship system to new sectors combined with increased financial support for training companies contributed to a marked increase in apprenticeship positions. In 2013, more than 18000 new apprenticeships contracts were signed (The Norwegian Directorate for Education and Training, 2014).

After Reform 94, the Norwegian model of vocational training can be characterised as a hybrid model, based on a combination of a state model and a corporatist model. A tripartite cooperation model has been established at the national and at the regional level. The National Council for Vocational Education and Training advises the Ministry of Education on the general framework of the 
national VET system. The Advisory Councils for VET are linked to each vocational education programme. They advise national authorities on the content of VET programmes and future skill needs. At the regional level, the County Vocational Training Committees advise on quality, provision, career guidance and regional development in VET.

In the years after the implementation of Reform 94, there have been challenges related to high dropout rates from vocational programmes. Around 30 per cent of the age cohorts have not completed and passed upper secondary education five years after they start in upper secondary education. The completion rates have remained remarkably stable at this level since the implementation of Reform 94. The dropout rates are particularly high in vocational programmes (Markussen, Frøseth, Sandberg, Lødding, \& Borgen, 2011). Completion rates in upper secondary education are given high political priority and are being monitored closely. A number of policy initiatives and programs have been implemented in order to reduce dropout, with a particular focus on students in vocational programmes. With a strong policy emphasis on dropout and educational attainment, less attention has been paid to students who complete their vocational training and to their transition from apprenticeship training to a more stable position in the labour market. As a consequence, research on transition patterns from school to work has been scarce.

\section{METHODS AND DATA}

The present analysis is based on register data from Statistics Norway linking data from the national register on education, the national register on employers/ employees and the national population register. The national education register provides data on three cohorts who received their trade certificates in 2009, 2010 and 2011 respectively. These data are linked to information about employment status as well as participation in further education for each subsequent year for these three cohorts. For those who received their trade certificate in 2009, we have data on employment status and further education for the three following years, in 2009, 2010 and 2011. For those who received their trade certificate in 2010, we have data for 2010 and 2011. For VET graduates from 2011, we only have transition data for one year.

Labour market data provide information on whether a person is employed or not, in which industry (NACE code), occupation and working time. The education registers provide information about individual participation in formal education, and in which type of education (level and field of study). The data files also contain personal background variables such as gender, age and country of birth, school grades and absence from upper secondary school. Data from the national education register, employer/ employee register and population register are considered to be reliable. However, the actual employment rate could be slightly higher than the level measured by registry data. Interview data tend to show a higher degree of employment than registry data among low-income groups, particularly among men (Andersen \& Vrålstad, 2013). As the data analysed here 
only covers a short time period, we do not have the opportunity to analyse changes over time and link these to economic cycles, reform initiatives or specific policy measures.

\section{LABOUR MARKET TRANSITIONS}

After the implementation of Reform 94, the number of persons who obtain their trade certificate through a combination of school based education and apprenticeship training has varied between 11000 and 16000 every year. In addition, 6-7000 persons obtain a trade certificate every year through an experience based trade certificate scheme (Statistics Norway, www.ssb.no). The latter group mainly consists of adults. In this chapter, we will concentrate on the persons who obtain their trade certificate through the main route, following a combination of school based education and apprenticeship training.

\section{Employment Rates}

Our analysis shows that a great majority of the cohorts who obtained their trade certificate in the three years period from 2009 through 2011 were employed shortly after they had obtained their trade certificates. After one year the employment rate was at 85 per cent or higher. The percentage that is employed increases slightly in the second and third year after obtaining the trade certificate.

The composition of the group who is outside the labour force varies from one year to another. Only 3.7 per cent of the graduates from vocational education in the 2009 cohort were outside the labour force in both 2009 and 2010. Only 1.6 per cent were outside the labour force in the three consecutive years covered by our analysis. Only 1.8 per cent were registered as unemployed for three consecutive years. This is slightly below the national average unemployment rate at 2.3 per cent. In the age group from 20-24 years, which is most comparable to the group graduating from vocational education, the unemployment rate was significantly higher, at 7.3 per cent. Only 0.1 per cent of those who obtained their trade certificate were unemployed in all three years after graduation. Thus, unemployment among VET graduates in Norway must in general be characterised as very low.

The employment rate varies between different vocational programs, but the variation is not substantial. Graduates from the Service and transport program and from the Technical and industrial production program have the lowest employment rates of all VET graduates (at 82 and 83 per cent, respectively).

The proportion that is neither in work nor education the first year after graduation is significantly higher in some vocational programs than in others. The proportion is highest for graduates from Service and transport and from Technical and industrial production. However, we find that the group neither in work or education is considerably reduced from the first to the second year after graduation in both programs (not shown here). 
Table 1. In employment or education one year after graduation, by education program. Trade certificate in 2011 (in per cent)

\begin{tabular}{lcccr}
\hline & Employed & $\begin{array}{c}\text { In } \\
\text { education }\end{array}$ & $\begin{array}{c}\text { Not in } \\
\text { employment } \\
\text { or education }\end{array}$ & N \\
\hline Building and construction & 92 & 3 & 5 & 2287 \\
Electricity and electronics & 87 & 5 & 9 & 1973 \\
Technical and industrial production & 83 & 4 & 13 & 2874 \\
Agriculture, fishing and forestry & 88 & 8 & 5 & 253 \\
Restaurant and food processing & 87 & 5 & 8 & 792 \\
$\begin{array}{l}\text { Design, arts and crafts } \\
\text { Service and transport }\end{array}$ & 92 & 4 & 4 & 673 \\
$\begin{array}{l}\text { Health care, childhood and youth } \\
\text { development }\end{array}$ & 88 & 6 & 13 & 1087 \\
& & 5 & 7 & 1845 \\
\hline
\end{tabular}

\section{Female VET Graduates in Part Time Work}

The majority of VET graduates who are employed are working full time, but there is also a significant proportion working part time. In our study, we apply a liberal definition of "full time work" as more than 32 work hours a week. A working time from 20 hours to 32 hours a week is considered long part time work, whereas less than 20 hours a week is defined as short part time work (Nyen, Skålholt, \& Tønder, 2013). Based on these definitions, about 67 per cent of the graduates from the 2011 cohort were working full time in November 2011. Nine per cent were working in long part time positions, while eleven per cent had short part time work. The remaining 13 per cent were either unemployed or outside the labour force.

The analysis reveals that there are large variations between different vocational programmes in upper secondary education in terms of the proportion of graduates working full time. The proportion who works full time is particularly low among graduates from the vocational program Healthcare, childhood and youth development. The low proportion working full time should be viewed in context of the general prevalence of part time work in the relevant sectors. Within health and social services in the municipal sector only one in three women are working full time (Moland \& Bråthen, 2012). Although part-time work is often voluntary, the limited availability of full time positions tends to be a challenge to young people needing to move into stronger and more stable positions in the labour market (Skålholt, Høst, Nyen, \& Tønder, 2013).

When analysing at the level of individual trades, we find that well-established vocational trades normally lead directly into full time positions. Plumbers, motor vehicle mechanics, electricians and carpenters are examples of trades where between 80 and 90 per cent of the graduates go directly into full time positions. In health care work, however, only 18 per cent enter into a full time job after obtaining their trade certificate. Other trades with a high proportion of part time workers are childcare and youth work, ICT service operations, and sales. 
Part-time work can be an indicator of challenges in the transition from apprenticeship training to full employment. However, part time work can also be related to the fact that work is not the main activity for all graduates from vocational training. We find that a large number of graduates combine education and work. In this context it is interesting to investigate more closely the transition patterns from vocational training to higher education.

\section{TRANSITIONS TO FURTHER EDUCATION}

In most European countries there is a tendency for a growing proportion of youth cohorts to attend higher education (OECD, 2014). However, education systems in different countries vary in terms of how early students are separated into academic or vocational tracks and in terms of opportunities to move from one track to another. In the Norwegian education system, opportunities to access postsecondary education varies considerably between different vocational programmes. In some areas, mainly within technical trades, there are established vocational pathways to post-secondary education. In other areas there are no such opportunities. Instead, those who have obtained a trade certificate have to return to upper secondary education for another school based year in order to qualify for higher education. In the latter case, vocational training and apprenticeship training can be perceived more or less as a detour to higher education.

Table 2. In education one year after VET graduation, by vocational program. Trade certificate in 2011 (in per cent)

\begin{tabular}{|c|c|c|c|c|c|}
\hline & $\begin{array}{c}\text { Upper } \\
\text { secon- } \\
\text { dary }\end{array}$ & $\begin{array}{c}\text { Voca- } \\
\text { tional } \\
\text { college }\end{array}$ & $\begin{array}{c}\text { Higher } \\
\text { edu- } \\
\text { cation }\end{array}$ & $\begin{array}{c}\text { Not in } \\
\text { edu- } \\
\text { cation }\end{array}$ & $N$ \\
\hline Building and construction & 5 & 4 & 1 & 90 & 2287 \\
\hline Electricity and electronics & 5 & 7 & 4 & 84 & 1973 \\
\hline Technical and industrial production & 6 & 16 & 2 & 76 & 2874 \\
\hline Agriculture, fishing and forestry & 6 & 10 & 7 & 77 & 253 \\
\hline Restaurant and food processing & 14 & 1 & 1 & 85 & 792 \\
\hline Design, arts and crafts & 9 & 1 & 1 & 89 & 673 \\
\hline Service and transport & 15 & 3 & 5 & 78 & 1087 \\
\hline $\begin{array}{l}\text { Health care, childhood and } \\
\text { youth development }\end{array}$ & 14 & 1 & 2 & 8 & 1845 \\
\hline
\end{tabular}

\section{Return to Upper Secondary Education}

In the Norwegian system of upper secondary education it is possible to choose a third supplementary year qualifying for higher education instead of applying for an apprenticeship after two years in vocational education. In the vocational programs Healthcare, childhood and youth development and in Service and transport almost half the students choose to take a supplementary year after the second year of a VET programme. This means that many students in vocational programs never 
enter apprenticeship training, but chose instead to switch to a general academic track. Some of these students do not even apply for an apprenticeship. Others apply, but are not offered an apprenticeship position (Frøseth, Hovdhaugen, Høst $\&$ Vibe, 2010). Our analysis of graduates from vocational training shows that the vast majority have work as their main activity the first year after they obtain their trade certificate. We find the highest proportion pursuing more education in programs that also have a large transition to a supplementary school year after two years in vocational education. These are Media and communication, Health care, childhood and youth development, and Service and transport. Within these programs around 10-15 per cent of the graduates return to the education system within one year after obtaining their trade certificate.

At the level of the individual trade we find that the proportion who returns to upper secondary education is particularly high for those who have been trained in Office and administrative work (15 per cent), ICT service (13 per cent), Childcare and youth development (12 per cent), and Health care work (11 per cent). These are all relatively new trades without strong traditions for apprenticeship training. The return to upper secondary education can probably be related to the perceived labour market opportunities for skilled workers within these trades. Health care workers and childhood and youth workers both enter into occupational labour markets characterised by clear distinctions between professional groups with higher education combined with a segment for unskilled workers. VET graduates may perceive that career opportunities provided for non-academics within these work organisations are limited. Instead, health care workers typically want to become trained nurses and a large number of the childhood and youth workers want to become kindergarten teachers (Skålholt et al., 2013). For those who have been trained in either ICT service work or Office and administrative work, the situation is somewhat different. These VET graduates do not necessarily enter into typical occupational labour markets. Nevertheless, they may have formed a perception during the course of apprenticeship training that their career opportunities could be limited without a general academic education.

\section{Transitions to Post-Secondary Education}

Most graduates from vocational education in Norway are not formally qualified for higher education, and direct transition from vocational training to universities and colleges is therefore usually not an option. A more relevant alternative is training offered at vocational colleges (fagskoler). These training institutions offer vocational education at the post-secondary level. The duration of courses and programmes at vocational colleges are from six months to two years. Vocational colleges are regulated by separate laws and are not part of the higher education system in Norway (The Norwegian Directorate for Education and Training, 2013). The proportion of VET graduates that continues with vocational training in a vocational college after obtaining a trade certificate is highest in technical and industrial production (16 per cent). The further development of vocational colleges 
in other sectors could be one way of strengthening vocational training and bridging initial VET to further vocational training.

\section{CONCLUSION}

The main research questions were to what extent vocational education and training gives access to the labour market and how transition patterns for skilled workers vary between different parts of the Norwegian labour market. The analysis of transition pattern from vocational training to the labour market reveals that the vast majority of those who obtained a trade certificate in the years 2009 through 2011 were working shortly after they obtained their trade certificate. The high employment figures suggest that vocational training in general provides skills and qualifications that are in demand in the Norwegian labour market. Still, we should be cautious when drawing conclusions from the analysis of register data solely from these three cohorts.

In the period we have investigated here, unemployment in Norway was low, including youth unemployment. In 2009-2011, the youth unemployment rate in Norway was between 9.2 and 8.6 per cent, compared to an average youth employment rate between 16.6 and 16.2 per cent in the OECD countries in the same period (ILO, 2013). Unskilled workers in Norway had access to jobs in open segments of the labour markets. From the register data analysed here, we do not know the relevance of training or to what extent the skilled workers actually needed their trade certificate in order to get their current job. Investigating transition patterns in a more difficult labour market situation would give a more robust test of the relevance of and demand for skills from vocational training in Norway. In order to get a more complete picture of the role of vocational education in different parts of the labour market the analysis of register data should be supplemented by other types of qualitative and quantitative data.

Although the vast majority of those who have obtained a trade certificate in 2009-2011 are either in work or in education, there is also a significant group who is outside education and work. The percentage falls during the three year period from nine to six per cent. Compared with most other countries, this is a small group (OECD, 2014). Still, it is important to investigate this group more closely, both in terms of individual characteristics and what kind of education they have pursued.

Some specific transition problems can be identified through our analysis of register data. To some extent, transition problems seem to be gender related. Norway still has a strongly gender segregated labour market. In several trades, it is difficult for VET graduates to get access to full-time employment after completing their apprenticeship. Several studies have documented that health care workers in particular have difficulties finding full-time or long part-time jobs. This could be part of an explanation of the growing tendency among students in upper secondary education, among female student in particular, to seek away from vocational training and move towards higher education.

It is a known challenge in many countries with apprenticeship training that students who perform well in school tend to escape vocational tracks in order to 
keep their options open for higher education (Busemeyer \& Trampusch, 2012). These educational choices could also be interpreted and related to increased uncertainty about labour market opportunities. In Norway this is a particular challenge within the Health care, childhood and youth development program. The increasing number of young students turning away from vocational tracks towards academic programs and higher education is also evident in other areas. In Norway, as in many other countries, there are many signs that young people try to keep their options open as long as possible. These strategies may also be related to the structuring of the labour markets and the position of skilled workers in the work organisation. The construction of pathways and bridges from vocational training to higher education is therefore a key issue in terms of developing vocational education under conditions of uncertainty about labour market demands and career opportunities.

\section{NOTE}

1 This chapter is based on research that has been previously been published in a Norwegian research report (Nyen, Skålholt, \& Tønder, 2013). The work was part of a larger research project that was carried out in cooperation between Nordic Institute for Studies in Innovation, Research and Education NIFU, Fafo Institute for Labour and Social Research, the University of Bergen and Oslo and Akershus University College of Applied Sciences. The research was financed by the Norwegian Directorate for Education and Training.

\section{REFERENCES}

Andersen, A., \& Vrålstad, S. (2013). Yrkesaktivitet i lavinntektsgruppen, Rapport 16/2013. Oslo: Statistisk sentralbyrå.

Aarum, R., \& Shavit, Y. (1995). Secondary vocational education and the transition from school to work. Sociology of Education, 68(3), 187-204.

Barth, E., \& von Simson, K. (2012). Ungdomsarbeidsledighet og konjunkturer. Økonomiske analyser, 5, 38-45. Oslo: Statistics Norway.

Busemeyer, M.R. \& Trampusch, C. (2012). The comparative political economy of collective skill formation. In M. R. Busemeyer \& C. Trampusch (Eds.), The political economy of collective skill formation (pp. 3-40). Oxford: Oxford University Press.

Frøseth, M. W., Hovdhaugen, E., Høst, H., \& Vibe, N. (2010). En, to...tre? Den vanskelige overgangen Evaluering av Kunnskapsløftet. Fra andre til tredje år $i$ videregående opplaring. NIFU-rapport $21 / 2010$.

Heinz, W. R. (2002). Transition discontinuities and the biographical shaping of early work careers. Journal of Vocational Behavior, 60, 220-240.

Høst, H. (Ed.). (2008). Continuity and change in Norwegian Vocational Education and Training (VET). Oslo: NIFU STEP report 29/2008.

Høst, H., Michelsen, S., \& Gitlesen, J. P. (2008). How the number of apprenticeships are influenced by policy and economic cycles. In H. Høst (Ed.), Continuity and change in Norwegian Vocational Education and Training (VET) (pp. 17-30). Oslo: NIFU STEP report 29/2008.

ILO. (2013). Global employment trends for youth 2013: A generation at risk. Geneva: ILO.

Jørgensen, C. H. (2013). The role and meaning of vocations in the transition from education to work. International Journal of Training Research, 11(2), 166-183.

Lamb, S., Markussen, E., Teese, R., Sandberg, N., \& Polesel, J. (Eds.). (2011). School dropout and completion. International comparative studies in theory and policy. Dordrecht: Springer. 


\title{
T. NYEN ET AL.
}

Markussen, E., Frøseth, M. W., Sandberg, N., Lødding, B., \& Borgen, J. S. (2011). Early leaving, noncompletion and completion in upper secondary education in Norway. In S. Lamb, E. Markussen, R. Teese, N. Sandberg, \& J. Polesel (Eds.), School dropout and completion. International comparative studies in theory and policy (pp. 253-271). Dordrecht: Springer.

Moland, L., \& Bråthen, K. (2012). Hvordan kan kommunene tilby flere heltidsstillinger? Fafo-rapport 2012:14.

Müller, W., \& Gangl, M. (2003). The transition from school to work: A European perspective. In W. Müller \& M. Gangl (Eds.), Transitions from education to work in Europe. The integration of youth into EU labour markets (pp. 1-22). Oxford: Oxford University Press.

Müller, W., \& Shavit, Y. (1998). The institutional embeddedness of the stratification process. A comparative study of qualifications and occupations in thirteen countries. In Y. Shavit \& W. Müller (Eds.), From school to work. A comparative study of educational qualifications and occupational destinations (pp. 1-40). Oxford: Clarendon Press.

The Norwegian Directorate for Education and Training. (2013). VET in Europe. Country report 2012 Norway. Oslo: The Norwegian Directorate for Education and Training.

The Norwegian Directorate for Education and Training. (2014). The education mirror 2014. Oslo: The Norwegian Directorate for Education and Training.

Nyen, T., Skålholt, A., \& Tønder, A. H. (2013). Overgangen fra fagopplæring til arbeidsmarkedet og videre utdanning. In H. Høst (Ed.), Kvalitet i fag- og yrkesopplceringen. Fokus på skoleopplaringen. Rapport 2 Forskning på kvalitet i fag- og yrkesopplaringen (pp. 159-198). NIFU Rapport Faforapport 2013:23.

OECD. (2014). Education at a glance 2014: OECD Indicators, OECD Publishing. http://dx.doi.org/ 10.1787/eag-2014-en

Skålholt, A., Høst, H., Nyen, T., \& Tønder, A. H. (2013). A bli helsefagarbeider. En kvalitativ undersøkelse av overganger mellom skole og laeretid, og mellom laretid og arbeidsliv blant ungdom $i$ helsearbeiderfaget. NIFU Rapport 5/2013 / Fafo-rapport 2013:05.

Smith, D. I. (2009). Changes in transitions: the role of mobility, class and gender. Journal of Education and Work, 22(5), 369-390.

Steedman, H. (2012). Overview of apprenticeship systems and issues. ILO contribution to the G20 Task Force on Employment. Geneva: International Labour Office.

\section{Torgeir Nyen}

Fafo Institute for Labour and Social Research, Norway

\author{
Asgeir Skålholt \\ Nordic Institute for Studies in Innovation, Research and Education NIFU, Norway
}

Anna Hagen Tønder

Fafo Institute for Labour and Social Research, Norway 


\title{
CARLA QUESADA-PALLARÈS, ANNA CIRASO-CALÍ, PILAR PINEDA-HERRERO AND ÀNGELA JANER-HIDALGO
}

\section{TRAINING FOR INNOVATION IN SPAIN}

\author{
Analysis of Its Effectiveness from the Perspective of Transfer of Training
}

\section{INTRODUCTION}

Innovation is a need for any organisation that wants to maintain and to improve its current market position, characterised by globalisation and uncertainty. Innovation processes involve creativity, development, change and to take risks, all of which depend on the skills of the people within the organisation. It is therefore interesting to study the role played by human resource development (HRD) in the innovation process, to identify ways to enhance innovation in our organisations through training. "Training for innovation" means training that aims to generate innovations in the organisation, i.e., that develops skills that allow the trainees to innovate in their work. This chapter presents some of the results of a research in Spain, focused on the evaluation of effectiveness of training for innovation.

\section{THEORETICAL FRAMEWORK}

Nowadays, innovation is necessary to ensure company's competitiveness, especially in market economies in which competitiveness is a characteristic feature of the economic situation. For companies, innovation is a key strategy to gain a competitive edge on other organisations (Fang et al., 2011). In this context, it is very important that organisations develop knowledge and skills of their employees to drive change and to build innovative capacity (CEDEFOP, 2012). Innovation in organisations is understood as a process whose goal is to develop changes, either in the form of products or processes, which add value and allow the organisation to gain a competitive edge in the market and to ensure their growth and survival (Bruton, 2011; Fang et al., 2011; Ridderstrale \& Nordström, 2008).

Ellström (2010) remarks that a new process is considered as an innovation when it is possible to demonstrate its contribution to the objectives of the organisation. The author makes a distinction between real innovation and potential innovation: an innovation is a real innovation when there is evidence of its contribution to the objectives of the organisation. However, if a given innovation has not been shown to contribute to the organisation and therefore lacks legitimacy in terms of results, it is a potential innovation. Results of the innovation process, in any field, must add 


\section{QUESADA-PALLARÈS ET AL.}

value to the organisation (Knox, 2002). However, to get results, the innovation process should be planned and should involve the acquisition and application of knowledge. According to Smith, Courvisanos, Tuck and McEachern (2011), knowledge and access to knowledge are some of the necessary elements for innovation to take place; therefore, knowledge management is crucial for innovation processes. According to these authors, the innovation capacity of an organisation depends largely on the ability to acquire, develop and exploit new knowledge, with human capital and technology as major factors affecting this process. It is therefore fundamental to develop learning processes within organisations. In their research, they argue that management of human resources and development of learning processes are key factors in promoting innovative capacity.

Some authors, like Nasution, Mavondo, Jekanyika, Matanda and OlyNdubisi (2011), emphasise that the way of measuring the level of innovation in an organisation more accurately is analysing human resource management practices. There is an increased likelihood that innovative processes will take place in an organisation when more attention is given to employees.

Various studies have shown that organisational learning and training play a very important role when it comes to generating innovation in organisations, as it allows constant learning of new skills (Ellström, 2010; Fuente, 2005; Jiménez-Jiménez, 2008; Rasiah, 2011; Yu Yuan, Ya-Hui, Yang, Wu, \& Kuo, 2011). For Hoeve and Nieuwenhuis (2006), innovation and development of new skills are processes that are intertwined. This means that knowledge management is a key factor in innovation processes. As it is highlighted by literature, the ability to innovate has a direct relationship with the ability to acquire and apply knowledge (Courvisanos, 2007; Soriano, 2013; Tidd, Bessant, \& Pavitt, 2005).

Innovation and training can be understood as two business strategies that must necessarily be related. Training is essential to develop innovation processes because it allows workers to acquire the knowledge needed to develop changes, and the skills needed to create and adapt to new situations arising from innovation (Fuente, 2005; Kontoghiorghes, Awbrey \& Feurig, 2005; Shipton, West, Dawson, Birdi, \& Patterson, 2006; Walsworth, 2007). Some authors, such as García (2008), emphasise that companies that are characterised by a high degree of innovation are those that offer more training to their workers, and this is where it plays a strategic role. Therefore, training must become training for innovation, whose ultimate goal is to provide adequate skills for workers, and then they can develop an innovation process.

By "training for innovation," we mean training that is intended to generate innovations in the organisation, in other words, that develops the necessary skills to allow trainees to innovate in their work (Pineda, 2013). It is therefore a different concept than innovative training, which is related to methodological innovations. Our study focuses on training that, irrespective of the more or less innovative methods used, generates innovation, that is, changes that generate added value for the organisation and give it a competitive advantage. Training for innovation can 
be a key tool to allow organisations to acquire skills according to needs of their economic and financial context.

Training is crucial for innovation, creating organisational cultures and management capabilities which stimulate and sustain innovation. (Smith et al., 2011, p. 12)

Among the studies on training that generates innovation, Edralin's (2007) contribution is particularly interesting. She considers that innovation takes place if there is an appropriate context in which organisational structure, culture and human resources practices such as training are geared towards innovation processes. The key aspects that stand out among the main features of training for innovation are based on those skills necessary for people to participate in an innovation process, such as critical thinking, initiative, effective communication, access and information analysis (Burton, 2011; Edralin, 2007; Fluellen, 2011).

Organisations invest many resources in training their employees, both for innovation and for regular tasks, but rarely know to what extent the training is effective. It is necessary to conduct an evaluation of the training to verify the effectiveness and cost of training, in terms of transfer of learning.

Baldwin and Ford (1988) were one the first authors to study "transfer of training" as an important training outcome. These authors defined it as the degree to which participants apply the knowledge, skills, and attitudes acquired in the context of training. The evaluation of transfer of training becomes a priority to know the effectiveness of training within the work context. However, an exhaustive process of evaluation of transfer requires many human and financial resources due to the difficulty of measuring changes caused by training in the workplace (Pineda, 2002).

To solve this problem, several authors raised the possibility of evaluating transfer indirectly, through the factors that influence the applicability of learning to the workplace. Such is the case of the models of Baldwin and Ford (1988), Burke and Hutchins (2007), Holton (2000), Noe (1986), Rouiller and Goldstein (1993), Thayer and Teachout (1995), among others. To evaluate transfer indirectly allows having a measurement of transfer factors in all the participants at the end of training, thus avoiding the problems of missing respondents sometime after the training. It offers also the possibility of predicting transfer and of improving those factors that are a barrier to transfer. Pineda, Quesada and Ciraso (2011) created the Model of Factors to Evaluate Transfer indirectly, called the FET model, which we present later.

This chapter has two aims: (1) to evaluate effectiveness of training for innovation, and (2) to compare it with training that is not oriented towards innovation. ${ }^{1}$ The study was conducted in the context of Spanish organisations, and the evaluation model used was the FET. 


\section{METHOD}

The study was correlational, based on a non-experimental and longitudinal design (Hernández, Fernández-Collado \& Baptista, 2006) carried out from April to July of 2012.

\section{Sample}

We used a non-probabilistic voluntary sampling method based on two criteria: training activities that finished between April and June 2012; and training activities whose final session was performed face-to-face. Some of these training activities were entirely developed face-to-face, while others were blended learning activities, i.e., combined classroom settings and eLearning during the same training programme. 2,708 trainees responded to the first questionnaire (t1) but only $66.7 \%$ of them reported an e-mail address to send them the second tool. Subsequently, the second questionnaire (t2) was sent to 1,807 trainees and 446 answered it (24.7\%). This chapter uses the sample formed by 2,708 trainees, who participated in 286 training activities in 35 Spanish companies.

Based on the main goal of this chapter, the study is focused on two different types of training: traditional training and training for innovation. Therefore, trainees were classified according to the type of training as Table 1 indicates. This classification was based on a previous questionnaire addressed to the training managers or trainers of these activities, aimed to identify the main characteristics of the training design and whether they were related to innovation processes within the organisation or not.

Table 1. Sample distribution according to type of training

\begin{tabular}{|c|c|c|c|}
\hline & Traditional training & Training for innovation & Total \\
\hline FET trainees $(\mathrm{t} 1)$ & 2,381 & 327 & 2,708 \\
\hline CdE trainees $(\mathrm{t} 2)$ & 419 & 27 & 446 \\
\hline
\end{tabular}

Table 2 offers a sample description based on profile variables of trainees.

\section{Instruments}

We used two self-report questionnaires in our research: the Factors to Evaluate Transfer indirectly questionnaire or FET (t1) and the Efficacy questionnaire or CdE (t2). Both instruments were addressed to trainees who participated in a training activity; the evaluation was therefore based on a self-report. 
Table 2. Sample description

\begin{tabular}{ll}
\hline Variables & Sample description \\
\hline Sex & Men: $49.2 \%$ \\
Age & Women: $50.8 \%$ \\
Type of company & Mean: 39 years $(9.52$ Standard Deviation) \\
& Private: $85.1 \%$ \\
& Public: $14.5 \%$ \\
Professional category of trainees & Non-profit organisations: $0.4 \%$ \\
& Manager: $3.6 \%$ \\
& Middle manager: $21.1 \%$ \\
& Technical: $22.8 \%$ \\
& Skilled employee: $45.4 \%$ \\
& Unskilled employee: $7.2 \%$ \\
& None: $0.5 \%$ \\
& Primary education: $7.5 \%$ \\
Educational level of trainees & Secondary education: $9.1 \%$ \\
& Medium vocational education: $15.3 \%$ \\
& High school: $11.3 \%$ \\
& High vocational education: $19.2 \%$ \\
& Undergraduate: $31.3 \%$ \\
& Graduate or master: $5.1 \%$ \\
& PhD or superior: $0.7 \%$ \\
\hline
\end{tabular}

The FET questionnaire used a paper-and-pencil format, and its goal was to analyse training efficacy; it was applied immediately following the end of training activities with the help of training managers or trainers, following an application procedure. The FET questionnaire was based on two different sections. The first one was formed by variables related to the profile of trainees (gender, age, e-mail address, type of company, professional category, and educational level, among others) and features of training (type of training, features of the innovation process, training features, and trainer profile).

The second section was made up by seven factors that determine transfer of training; this section corresponds to the FET model (Pineda, Quesada, \& Ciraso, 2011), which was applied to different samples to achieve a valid and reliable model (Pineda-Herrero, Quesada-Pallarès, \& Ciraso-Calí, 2014). The factors that composed the FET questionnaire were: satisfaction with training, motivation for transfer, internal locus of control, orientation towards job requirements, environment opportunities for application, accountability, and organisation's support for transfer. These factors were represented by 42 items based on a 5-point Likert scale (1: no agreement; 5: total agreement). The FET section presents a good adjustment with data $(\mathrm{CFI}=.90, \mathrm{NFI}=.88)$ and a low error for the model $($ RMSEA $=.47)$. Moreover, this section of the questionnaire has a high internal consistency $(\alpha=.92)$, a trait that is consistent throughout all of the factors $(\alpha \geq$ $.70)$.

The CdE questionnaire used a web format sent by e-mail to those who answered the FET questionnaire. Its goal was to analyse transfer level three months 


\section{QUESADA-PALLARÈS ET AL.}

after employees finished the training activity. 15 days were granted to answer the questionnaire and two reminders were sent, following the CdE procedure. CdE was formed by 30 items and three sections: 1) seven items that evaluate transfer level under one construct measured by a 5-point Likert scale (1: no agreement; 5: total agreement); 2) 16 items to identify reasons why trainees felt that their transfer level was low or high (trainees only answered a set of seven items based on their response in item number seven), measured by a 5-point Likert scale (1: no agreement; 5: total agreement); and 3) seven items to ask about the main reason why trainees had a low rate of transfer (if they had a low rate of transfer), measured by multiple-choice items.

The first section of the CdE was validated through an Exploratory Factor Analysis (EFA) using the Maximum Likelihood method, an eigen value greater than one, a promax rotation, and a minimum value of .30. Barlett test $(p<.05)$ and KMO index (.92) suggested that the model was adequate. The model emerged explains the $63.7 \%$ of the variance with one factor, which confirmed that the construct represented one dimension. The factor was named deferred transfer and showed a high internal consistency $(\alpha=.92)$.

\section{Data Analysis}

The data was entered into an Excel database, after which it was analysed using the SPSS v.17 Inc. statistics programme.

Analyses carried out where different according to research goals. We performed a descriptive analysis of data, followed by mean comparison tests (ANOVA), and multiple regressions. However, we started the data analysis by ensuring the normality of the sample, and carrying out a data screening.

\section{RESULTS}

The following table illustrates the descriptive analysis of transfer factors based on the type of training (related or not to innovation processes). Results are displayed on a scale from 1 to 5 .

Most of the factors scored an average value between 3 and 4: this indicates that they facilitate transfer although that can be improved in order to enhance training effectiveness on the job. However, accountability is the lowest factor, and could almost be considered a factor that could possibly hinder transfer. On the other hand, satisfaction with training and motivation to transfer display quite high values in both cases.

Comparing results of traditional training and training for innovation, a number of differences emerge, although not all of them are statistically significant. Oneway ANOVA between subjects were performed in order to highlight the differences in factors values depending on the type of training. 
Table 3. Factor descriptive analysis and differences between training for innovation and traditional training

\begin{tabular}{llll}
\hline Factor & $\begin{array}{l}\text { Training for } \\
\text { innovation }\end{array}$ & $\begin{array}{l}\text { Traditional } \\
\text { training }\end{array}$ & Difference \\
\hline Satisfaction with training & 4.21 & 4.31 & $-0.10^{*}$ \\
Motivation to transfer & 4.23 & 4.08 & $-0.15^{*}$ \\
Environment opportunities for & 3.60 & 3.47 & \\
application & & & $-0.13^{*}$ \\
Organisation's support for transfer & 3.57 & 3.59 & 0.02 \\
Internal locus of control & 3.74 & 3.52 & $-0.22^{*}$ \\
Orientation towards job's requirements & 3.82 & 3.75 & -0.07 \\
Accountability & 3.13 & 3.14 & 0.01 \\
\hline Note: ${ }^{*} p<.01$ & & &
\end{tabular}

The motivation of trainees to apply what they have learned to the job place is significantly different at the $p<.01$ level $[F(1,2704)=18.70, p=.000]$. Motivation to transfer is 0.15 higher in training that is not related to innovation processes in the company or institution.

Other two internal factors in trainees that have significant differences are locus of control and satisfaction with training. In training for innovation, trainees tend to be less satisfied $(0.10)$ than trainees in traditional training programmes $[F(1,2699)$ $=8.07, p=.005]$. In addition, they tend to have a more external locus of control (0.22) than trainees who participate in training activities that are not related to innovation $[F(1,2702)=17.31, p=.000]$.

Finally, there is a difference in a factor that is linked to the institutional environment, as perceived by trainees. Environment possibilities to apply obtains a significantly higher score $(0.14)$ in traditional training than in training for innovation $[F(1,2704)=9.42, p=.002]$.

These differences show better factors results in traditional training than in training related to innovation processes. However, the second questionnaire $(\mathrm{CdE})$ focused on perceived transfer after three months indicates that training for innovation has a higher degree of deferred transfer, with a mean value of 3.35 (on a 5-points scale); while the same variable within traditional training obtained 3.01. One-way ANOVA demonstrated that this difference is significant at the $p<.05$ level $[F(1,409)=4.42, p=.036]$.

In order to understand how factors affect transfer and to better explain training effectiveness, two different multiple regression models were performed according to the type of training (related or not to innovation processes). All assumptions were tested beforehand in order to carry out multiple regression models.

First of all, results of FET and CdE questionnaires from those trainees who participated in traditional training were selected. The seven factors were introduced as independent variables, obtaining an adjusted $R^{2}$ of .29 . However, satisfaction with training, motivation to transfer, organisation's support for transfer, internal locus of control and accountability were not significant. In the second analysis, these factors were excluded, and a model with two significant factors emerged, 


\section{QUESADA-PALLARÈS ET AL.}

which explains the $27.7 \%$ of transfer variance (see Table 4). From the analysis of standardised coefficients, it emerges that the most important factor within this model is orientation towards job requirements.

Table 4. Multiple regression model on traditional training transfer

\begin{tabular}{|c|c|c|c|}
\hline \multirow{2}{*}{ Factors } & \multicolumn{2}{|c|}{ Non-standardised coefficients } & \multirow{2}{*}{$\begin{array}{c}\text { Standardised } \\
\text { coefficient Beta }\end{array}$} \\
\hline & $B$ & Standard error & \\
\hline (Constant) & .385 & .241 & \\
\hline $\begin{array}{l}\text { Environment opportunities } \\
\text { for application }\end{array}$ & .117 & .048 & $.106^{*}$ \\
\hline $\begin{array}{l}\text { Orientation towards job } \\
\text { requirements }\end{array}$ & .576 & .050 & $.502 * *$ \\
\hline
\end{tabular}

Note: $* p<.05 ; * * p<.01$

The effect size of the model on transfer in traditional training is $f^{2}=0.39$; according to Cohen (1992), the interpretation of this value indicates a low effect size; thus, the amount of transfer variance explained by this model is quite low.

Secondly, another multiple regression was performed, only including training activities identified as "for innovation." The introduction method was used with seven factors of the FET model, and it obtained an adjusted $R^{2}$ of .71 . Once factors that were not significant were excluded, the regression model was re-tested with only motivation to transfer, environment opportunities for application and organisation's support for transfer. This model, displayed in Table 5, explains the $68.2 \%$ rate of transfer variance; in other words, the regression model in training for innovation fits the data better than the model analysed for transfer of traditional learning.

Table 5. Multiple regression model on transfer in training for innovation

\begin{tabular}{|c|c|c|c|}
\hline \multirow{2}{*}{ Factors } & \multicolumn{2}{|c|}{ Non-standardised coefficients } & \multirow{2}{*}{$\begin{array}{l}\text { Standardised } \\
\text { coefficient Beta }\end{array}$} \\
\hline & $B$ & Standard error & \\
\hline (Constant) & -3.366 & .906 & \\
\hline Motivation to transfer & .614 & .245 & $.341 *$ \\
\hline $\begin{array}{l}\text { Environment opportunities } \\
\text { for application }\end{array}$ & .592 & .151 & $.453 * *$ \\
\hline $\begin{array}{l}\text { Organisation's support to } \\
\text { transfer }\end{array}$ & .603 & .193 & $.414 * *$ \\
\hline
\end{tabular}

Note: $* p<.05 ; * * p<.01$

In this case, the effect size is $f^{2}=2.55$, which means that the amount of transfer variance explained by this model is high. In fact, the effect size is large according to Cohen's (1992) interpretation.

In the following figure, an overview of the two different models is presented, along with the Beta values for each factor. The only factor that has an impact on transfer in both kinds of training (for innovation or not) is environment 
opportunities for application. However, the standardised coefficient shows that the relative importance of this factor in the model of training for innovation is greater than in traditional training. On the other hand, orientation towards job requirements is not significant in the regression model for transfer in training for innovation, whereas it is the most important factor in transfer in traditional training. It is also noteworthy that the only internal factor of trainees that emerges is motivation to transfer, and it only has a significant relationship to transfer when training is related to an innovation process in the company.

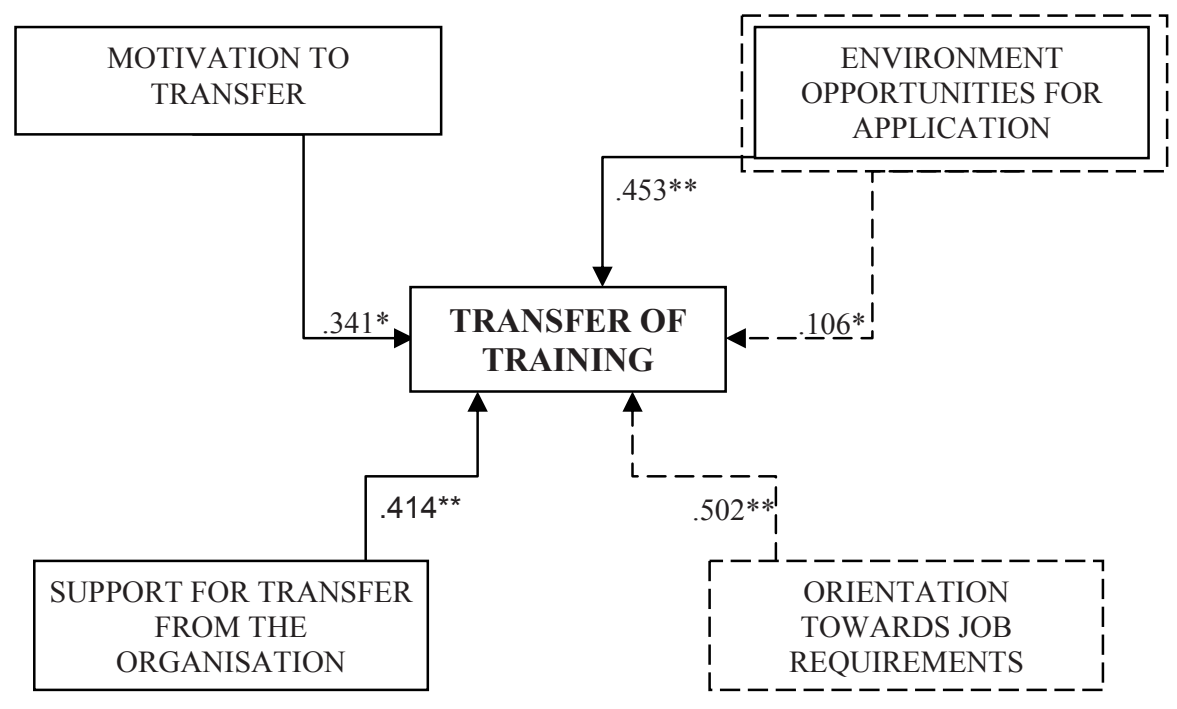

Note: $* p<.05 ; * * p<.01$

Factor to transfer in training for innovation

---- Factor to transfer in traditional training

Figure 1. Overview of the multiple regression models (Beta displayed)

\section{DISCUSSION}

Innovation is one of the solutions available to organisations today to overcome the economic crisis, especially in Spain, where production and services are increasingly offshore to other countries with lower salaries or lower taxes (CEDEFOP, 2012). Despite this situation, human resource development and training is one of the best ways to generate innovation in organisations and to help employees cope with changes demanded by innovation (Ellström, 2010).

Training for innovation is a strategy companies can use to gain a competitive edge on other organisations. However, from the perspective of effectiveness, is training for innovation more effective - or more transferred - than other forms of 


\section{QUESADA-PALLARÈS ET AL.}

training? An evaluation of transfer allows us to explore this question, which is why it is the aim of this chapter. The results of FET model show that training for innovation has a higher degree of deferred transfer, in other words, that trainees perceive that they transfer more learning to the workplace when learning is related to innovation than when it is not. This result is significant because it shows that training for innovation is more effective than traditional training; hence, organisations that want to obtain returns on their investments in training should prioritise training for innovation (Martínez-Ros \& Orfila-Sintes, 2012).

This result can be explained by considering the results of Pineda (2013): training for innovation tends to emerge from a collaborative process of needs assessment; it is carried out during working hours; it has follow-up sessions; it uses a variety of methodological strategies; it encourages positive attitudes towards change; and the trainer's role is to accompany the trainee, who leads his or her own learning process.

FET model results show significant differences between the transfer factors of both types of training: motivation to transfer, internal locus of control, satisfaction with training factors obtain significantly higher scores in traditional training than in training for innovation. These results can be explained by the fact that a significant amount of traditional training is of a voluntary nature, whereas training for innovation is often compulsory, as innovation requires implementation. The compulsory nature of training for innovation may detract to the motivation and satisfaction of trainees. Nevertheless, despite lower scores in these factors, results clearly show that training for innovation generates an increased level of transference, and is therefore more effective.

A number of differentiated models of transference factors in traditional training and in training for innovation have emerged from multiple regression analysis. In traditional training, the two factors that have a significant effect on transfer are orientation towards job requirements and environment opportunities for application. On the other hand, in the model related to training for innovation, the most significant factor was environment opportunities for application followed by motivation to transfer. This means that the possibilities of a work environment are a relevant factor in both models, even though they have a greater relative importance in training for innovation. These results are concordant with those of other studies that show that organisations with human resource development policies focused on developing and managing knowledge have an increased capacity for innovation (Smith et al., 2011). Being in an environment with possibilities for application, as well as motivation and support for transfer is typical of environments focused on the development of human resources, environments in which training for innovation is most effective.

Considering that the motivation to transfer and environment opportunities for application factors often yield lesser scores in training for innovation than in traditional training, it might be necessary to focus on them in order to improve the effectiveness of these training actions. This is particularly true for environment opportunities for application, whose average score is insufficient to consider it to be a significant factor in the explicative model on transfer variance. It might be 
necessary to carry out changes in the workplace environment and to ensure that workers are in a setting that is appropriate to apply the innovation they have learned to improve this aspect.

The motivation to transfer factor also yielded a lower score in training for innovation, and the regression model has revealed that it might be possible to obtain more effective training that results in a greater level of transfer. To this end, it would be beneficial to draw out strategies for workers to become involved in the innovation process and for them to become aware of their importance and, hence, the need to pursue their training. Ideally, workers should not participate in innovation due to its obligatory nature, but rather out of interest in the innovation process, or out of a will to improve their work; this would encourage motivation among workers to apply what they have learned throughout their training.

The factor organisation's support for transfer has a significant impact in the transfer model for training for innovation, although scored relatively low; hence, improving this would result in an increased level of application of training in the workplace. For training for innovation to be effective, it is necessary that managers and co-workers support their colleagues when it comes to applying what they have learned.

This study has allowed us to do a first analysis of the effectiveness of training for innovation in Spanish companies and the factors that take part in it. Results reveal that training for innovation generates more transfer than training that is not geared towards innovation. Nevertheless, there is still much to explore; it would be interesting to study the transfer factors that present significant differences between training for innovation and traditional training in-depth in order to understand the motives behind these differences. We hope that those results will cast light on the usefulness of training in innovation processes, especially at a time when innovation is a key factor in improving the competitiveness of our economy.

\section{NOTE}

1 This chapter is part of a broader research project developed in 2012 and funded by the Fundación Tripartita para la Formación en el Empleo: "Evaluación de la Eficacia de la Formación para la Innovación: Análisis de Casos de Éxito” (C20110373).

\section{REFERENCES}

Baldwin, T.T., \& Ford, J.K. (1988). Transfer of training: A review and directions for future research. Personnel Psychology, 41(1), 63-105.

Bruton, D. (2011). Learning creativity and design for innovation. International Journal of Technology and Design Education, 21(3), 321-333.

Burke, L.A., \& Hutchins, H. M. (2007). Training transfer: An integrative literature review. Human Resource Development Review, 6(3), 263-296.

CEDEFOP (2012). Learning and innovation in enterprises. Research paper. Luxembourg: Publications Office of the European Union.

Cohen, J. (1992). A power primer. Psychological Bulletin, 112(1), 155-159.

Courvisanos, J. (2007). The ontology of innovation: human agency in the pursuit of novelty. History of Economics Review, 45, 41-59. 


\section{QUESADA-PALLARÈS ET AL.}

DeInTra. (2008). Report on the barriers and gaps hindering the deployment of innovative training methodologies in European training systems for workers. Education and Culture DG.

Edralin, D. M. (2007). Human capital development for innovation in Asia: Training and development practices and experiences of large Philippine companies. Asian Journal of Technology Innovation, 15(1), 133-147.

Ellström, P. (2010). Practice-based innovation: A learning perspective. Journal of Workplace Learning, 22(1/2), 27-40.

Fang, S., Chou, C., Yang, S., \& Tsai, F. (2011). Relationship learning and innovation: The role of relationship-specific memory. Industrial Marketing Management, 40(5), 743-753.

Fluellen Jr, J. E. (2011). Creating a nation of innovators. A brief report. Online Submission, 18. Available online at: http://files.eric.ed.gov/fulltext/ED531063.pdf (accessed 13 February 2014).

Fuente, R. (2005). Formación continua como factor de innovación y calidad. I Jornadas "La calidad en el sistema educativo." Burgos: Universidad de Burgos.

García, I. (2008). Formación e innovación en las empresas industriales. Papers: Revista de Sociología, $88,179-194$.

Heiskanen, T., \& Heiskanen, H. (2011). Spaces of innovation: experiences from two small high-tech firms. Journal of Workplace Learning, 23(2), 97-116.

Hernández Sampieri, R., Fernández-Collado, C., \& Baptista Lucio, P. (2006). Metodología de la Investigación (4th ed.). México DF: Mac Graw Hill.

Hoeve, A., \& Nieuwenhuis, L. F. (2006). Learning routines in innovation processes. Journal of Workplace Learning, 18(3), 171-185.

Holton, E. F., Bates, R. A., \& Ruona, W. E. A. (2000). Development of a generalized learning transfer system inventory. Human Resource Development Quarterly, 11(4), 333-360.

Jiménez-Jiménez, D., \& Sanz-Valle, R. (2008). Could HRM support organizational innovation? The International Journal of Human Resource Management, 19(7), 1208-1221.

Knox, S. (2002). The boardroom agenda: Developing the innovative organisation. Corporate Governance, 2(1), 27-36.

Kontoghiorghes, C., Awbrey, S. M., \& Feurig, P. L. (2005). Examining the relationship between learning organization characteristics and change adaptation, innovation, and organizational performance. Human Resource Development Quarterly, 16(2), 185-211.

Martínez-Ros, E., \& Orfila-Sintes, F. (2012). Training plans, manager's characteristics and innovation in the accommodation industry. International Journal of Hospitality Management, 31(3), 686-694.

Nasution, H. N., Mavondo, F. T., Jekanyika Matanda, M., \& OlyNdubisi, N. (2011). Entrepreneurship: Its relationship with market orientation and learning orientation and as antecedents to innovation and customer value. Industrial Marketing Management, 40, 336-345.

Noe, R. A., \& Schmitt, N. (1986). The influence of trainee attitudes on training effectiveness: Test of a model. Personnel Psychology, 39, 497-523.

Pineda, P. (coord.). (2002). Gestión de la formación en las organizaciones. Barcelona: Ariel.

Pineda, P. (dir.). (2013). Evaluación de la eficacia de la formación para la innovación. Análisis de casos de éxito. Madrid: Fundación Tripartita para la Formación en el Empleo. Available online at: http://www.fundaciontripartita.org/almacenv/webpubpro/textbase/aacc02/anexos/20110373.pdf (accessed 13 February 2014).

Pineda, P., Quesada, C., \& Ciraso, A. (2011). Evaluating training effectiveness: Results of the FET Model in the Public Administration in Spain. Paper presented to the 7th International Conference on Researching Work and Learning. Shanghai: Normal University of China.

Pineda-Herrero, P., Quesada-Pallarès, C., \& Ciraso-Calí, A. (2014). Evaluation of training transfer factors: The FET model. In K. Schneider (Ed.), Transfer of learning in organizations (pp. 121-144). Germany: Springer International Publishing.

Rasiah, R. (2011). Epilogue: Implications from industrializing East Asia's innovation and learning experiences. Asia Pacific Business Review, 17(2), 257-262.

Ridderstrale, J., \& Nordström, K. (2008). Funky business forever. How to enjoy capitalism ( ${ }^{\text {rd }}$ ed.). Harlow: Pearson (Financial Times Prentice Hall). 
Rouiller, J. Z., \& Goldstein, I. L. (1993). The relationship between organizational transfer climate and positive transfer of training. Human Resource Development Quarterly, 4(4), 377-390.

Shipton, H., West, M., Dawson, J., Birdi, K., \& Patterson, M. (2006). HRM as a predictor of innovation. Human Resource Management Journal, 16(1), 3-27.

Smith, A., Courvisanos, J., Tuck, J., \& McEachern, S. (2011). Building innovation capacity: The role of human capital formation in enterprises - A review of the literature. Adelaide: NCVER.

Soriano, D. (2013). Innovation and entrepreneurship in knowledge industries. Journal of Business Research, 66(10), 1964-1969.

Thayer, P. W., \& Teachout, M. (1995). A climate for transfer model. Brooks Air Force Base, TX: Technical Training Research Division, Armstrong Laboratory.

Tidd, J., Bessant, J., \& Pavitt, K. (2005). Managing Innovation: Integrating technological, market and organizational change ( $3^{\text {rd }}$ ed.). New York: John Wiley \& Sons.

Walsworth, S., \& Verma, A. (2007). Globalization, human resource practices and innovation: Recent evidence from the Canadian Workplace and Employee Survey. Industrial Relations: A Journal of Economy and Society, 46(2), 222-240.

Yu Yuan, R., Ya-Hui, B., Yang, B., Wu, C., \& Kuo, Y. (2011). Impact of TQM and organizational learning on innovation performance in the high-tech industry. International Business Review, 20(2), 213-225.

\section{Carla Quesada-Pallarès}

Leeds University Business School

University of Leeds, United Kingdom

Anna Ciraso-Cali

Departament de Pedagogia Sistemàtica i Social

Universitat Autònoma de Barcelona, Spain

Pilar Pineda-Herrero

Departament de Pedagogia Sistemàtica i Social

Universitat Autònoma de Barcelona, Spain

Àngela Janer-Hidalgo

Departament de Pedagogia Sistemàtica i Social

Universitat Autònoma de Barcelona, Spain 



\author{
RAFAEL M. HERNÁNDEZ CARRERA AND \\ EMILIO LUCIO-VILLEGAS
}

\title{
15. VOCATIONAL EDUCATION AND TRAINING FROM THE PERSPECTIVE OF KEY INFORMANTS OF EMPLOYER ASSOCIATIONS IN SPAIN
}

\author{
A Qualitative Analysis
}

\begin{abstract}
INTRODUCTION
Over the last twenty years there has been well-structured vocational education and training (VET) in Spain involving both employer associations and trade unions. The model was built in 1992, after the first National Agreement for Vocational Education was signed. This added the agreement of trade unions and employers to the system of vocational education until the end of 2012. Since then, the whole previous system has been questioned due to several factors. According to some politicians, the training industry and some trade union representatives, there has been an excessive involvement of trade unions and employer associations in the management of the VET system. This issue and the emergence of irregular practices have made various governments reflect on the continuity of the model. All this leads us to a situation of uncertainty, without a clear VET model, promoting a great sense of instability.

This study aims to empirically explain the perception of key informants of Spanish business associations and their training managers about the current status of the system of vocational training, concerning adult employed workers. We want to obtain a clear statement from the main players of business and associations on the issue, including highlighting the employer associations' main interests in joining the management and direction of the system of Vocational Education for Workers. Lastly through this research we will undertake a critical analysis of the employers' interests and engagement in VET.

Trade unions also have a great interest in joining the organisation of vocational training for workers. In the words of Forrester "Labour organizations have always been interested in the training of their members. Knowing enough to enter the labour market, maintaining and even progressing within a job, have been the historical underpinnings for the origins and continuation of unionism" (2007, p. 63). Obviously the relevance of this statement depends on which type of trade union is referred to. Worker training is an important tool for the promotion of those workforce skills and knowledge necessary to cope with and engage in the
\end{abstract}


competitive global environment. Normally this type of training is developed in an organised way, with a clear program and competencies to achieve. However, another type of education is also present in the working world that does not clearly respond to this training paradigm. On the contrary, it is more related to everyday learning. It is informal learning that is not necessarily linked to the classroom, and it is equally important for individuals' personal and professional development. "Learning is taken as something that occurs as part of everyday thinking and acting. It is not reserved for the classroom (...); it is ongoing in our everyday experiences. If we are thinking and acting, we are learning" (Billett, 2001, p. 6). In other words, despite the development of skills and knowledge there is a learning culture in everyday life, which is what we call "everyday learning." In the words of Olesen, "each professional may learn during his professional practise, and thereby increase his or her individual capacity to conduct professional work, as well as most likely gain insights for his/her own life in general" (Olesen, 2007, p. 24). As such, when we refer to the term worker education we should bear in mind the development of knowledge, skills and attitudes in both the traditional realm of planned training with a concrete objective, and the realm of experience (professional and daily).

We can now see how government policies related to VET are putting more emphasis on skill training rather than knowledge. This has a major impact on the way of organising the vocational training system for employment, as the state gives higher priority to qualifications than to the process of teaching and learning. "The new VET policies all attempt to make vocational education more skills - and less knowledge - based and have the focus on learning outcomes rather than on inputs such as curricular programmes and teacher and trainers roles" (Rauner \& Maclean, 2008, p. 145).

Sometimes government policies in adult education and the training activities in companies have different goals. The former try to help through vocational education to increase the employability and mobility of workers across firms and sectors, while the latter are more interested in the training of high-level workers to prepare them for more specific issues and work processes (CEDEFOP, 2011a). Notwithstanding, active employment policies and investment in ongoing education and training appear to be contributing positively to stimulate the effort to overcome the current economic crisis (CEDEFOP, 2011b).

All of this leads us to analyse the status of VET in Spain from the perspective of key actors in business associations, bearing in mind the differentiation between the skills and knowledge as well as the intention of the Spanish Government in Vocational Education.

\section{METHODOLOGY}

First we would like to highlight that this research is focused on a qualitative methodology. The interview is the principal instrument for collecting information. It is based on semi-structured interviews with key characters within the world of employer associations in Spain. 
Notwithstanding the above, we have conducted an investigation through which we have tried to understand the current situation of the VET system in Spain from the point of view of training directors and other main actors in employer associations. In other words, we have tried to show how worker training and training in enterprises are perceived by people involved in these issues in employer associations. Our aim is not to demonstrate the official position of employer associations on these issues; it is to find out the personal opinion of the most qualified people in these associations. We are interested in the personal view of these key actors because the official position of the organisations not always are related with the perspectives of those who are working everyday in worker education.

\section{Worker Training from the Perspective of Key Informants of Employers' Associations}

Now, we enter the main area of this research, i.e., the worker training qualitative analysis from the perspective of key informants of employer associations. As mentioned above, this study is based on interviews with key individuals within employer associations that are related to training. Most of the interviewees are training directors of national, regional, provincial and sectorial employer associations. Intermediate managers and two chairmen of employer associations have also been interviewed. We have also taken as empirical material the transcription of a debate in which both employer organisations and union representatives participated. We consider that it is very important to include the perspective of these union representatives in order to provide an external view to the employer associations. This may be useful to balance the collected data in the other interviews.

The interviews were carried out with a series of questions closely related to the public interest about the VET situation in Spain. Nevertheless, we gradually adapted the general concepts of the interviews to the knowledge and opinions of the interviewees; focusing on the most important issues.

- Purpose of worker training.

- How training aimed at personal development affects the development of the company.

- Vocational training funds not used for worker training.

- Reasons why business associations are interested in creating VET programs.

- Malpractice or fraudulent practices in the field of VET.

- VET as a source of financing structures and political apparatuses of employers' associations and Trade Unions.

- Opinion on the current status of VET.

- Who benefits from the new VET model that is being created?

- Perception of the past 20 years of VET. Achievements?

- Position of employers' associations and Trade Unions in the current VET framework. 


\section{The Grounded Theory as Research Methodology}

We based our research on the Grounded Theory as a research methodology. It was developed by Glaser and Strauss (1967) and consists of a methodology that tries to develop a theory based on the collecting and systematic analysis of the empirical data of fieldwork. In this methodology there is not an initial hypothesis. It is based on the inductive analysis of the qualitative data to form a specific theory about the object of research, in our case, the perception of employer association concerning VET in Spain.

Sampling. First of all we would like to say that we got the express consent of the interviewees to use the contents of the interviews in this research. The sampling methodology of Grounded Theory is called Theoretical Sampling and, as it happens with other qualitative techniques, individuals are not chosen from the beginning with a specific criterion, but are incorporated into the sample as the research process goes along. Although in our case, we were clear that we wanted to hear the opinion of those in charge of training in employer associations, we did not select a sample based on a specific criterion. In this vein we do have a first idea of people to be interviewed (Training directors and other representatives), although the final sample came up as we went along in the interviews and the analysis thereof. Therefore, we delimited our sample to those in charge of training but without a clear selection criterion depending on the type of organisation, experience in the position, etc. The selection of individuals was performed taking into account the ones who were more likely to possess relevant information regarding the study. In order to determine the final number of interviews, the theoretical saturation criterion was followed. We finished the interviews when the appearance of new information fields that could be interpreted stopped.

Finally, our sample was limited to eleven people. Most of them were representatives of Employer Associations (Chief Learning Officers and Chairs) as well as two representatives from the main Trade Unions in Spain (Training Secretaries of UGT and CCOO). The Employer Association representatives interviewed were members of Spanish Confederation of Business Associations (CEOE), Employer Association of Catalonia (Foment del Treball), Employer Association of Seville (CES), Employer Association of Toledo (FEDETO), Employer Association of Asturias (FADE), Association of e-learning suppliers (APEL) and Consultancy Companies Association (AEC). The last interviewee was a former Spanish Minister of Labour.

\section{Findings through the Analysis of the Interviews}

Firstly, the interviews were transcribed, condensed/summarised and, after that, a process of coding was developed. The technique of coding in Grounded Theory is called Theoretical Coding and it is built up of three different procedures that can be mixed along the coding process: Open Coding, Axial Coding and Selective Coding. From the point of view of Flick (2012) these three procedures should not be identified as clearly differentiated but as different ways to manage the textual 
materials. The researcher can move from one to another or combine them if it is necessary.

Open Coding. In the Open Coding phase, an initial organisation of the interviews' data and materials were made. In our case, this first step was to carefully listen to and repeat all the recordings, and then reread the transcripts in an analytical and comprehensive way. The categories that emerged during the process are mentioned in Table 1. These categories are the information nodes around which

Table 1. Categories from the open coding of interviews

\begin{tabular}{|c|c|}
\hline Categories & Sub-categories \\
\hline Years of experience in training & $\begin{array}{l}\text { Previous experience before employer } \\
\text { association (membership) }\end{array}$ \\
\hline \multicolumn{2}{|l|}{ Experiential learning (practical training) } \\
\hline Purpose of worker training & $\begin{array}{l}\text { Training focused on the performance } \\
\text { Training as personal and professional } \\
\text { growth } \\
\text { Training for undertaking enterprises } \\
\text { (self-employment) } \\
\text { Training to raise productivity } \\
\text { Training for professional retraining } \\
\text { Worker motivation }\end{array}$ \\
\hline \multicolumn{2}{|l|}{ Purpose of training funds } \\
\hline $\begin{array}{l}\text { Involvement of the company in training } \\
\text { Interest of the Associations in workers training } \\
\text { Bad practices }\end{array}$ & Worker motivation \\
\hline Teaching methodologies & E-learning \\
\hline Management of training & $\begin{array}{l}\text { Employer associations as worker } \\
\text { training enterprises }\end{array}$ \\
\hline Organisation & Schedule of training \\
\hline \multicolumn{2}{|l|}{ General perception of worker training } \\
\hline \multicolumn{2}{|l|}{$\begin{array}{l}\text { Reason to choose training in an employer } \\
\text { association }\end{array}$} \\
\hline $\begin{array}{l}\text { Situation of the VET in Spain and policy } \\
\text { changes }\end{array}$ & $\begin{array}{l}\text { Affects of the situation } \\
\text { Political interventionism } \\
\text { Current position of the employer } \\
\text { associations }\end{array}$ \\
\hline Types of programmes & $\begin{array}{l}\text { On demand training } \\
\text { On offer training }\end{array}$ \\
\hline Voluntary nature of worker training & \\
\hline
\end{tabular}


the different selected sections of the interview texts are grouped. At first, sixteen categories appeared, from which seventeen more subcategories emerged. Within these categories, the totality of the interviews and other materials (such as field notes or memos) were coded as they arose during the coding process.

Due to a question of space, we will simply define the most codified categories in our research in Table 1.

Situation of the VET in Spain and policy changes: This refers to the situation that training for employment is going through in Spain, which is characterised by a fall in training activities and programs.

Purpose of worker training: This refers to how the interviewees view worker training; how they understand its ultimate purpose, which should be its main objective and goals.

Bad practices: This refers to the bad practices that have happened over the years in the realm of worker training and training for employment.

Purpose of training funds: This refers to the origin of financing for worker training. We will also look at how these funds are actually used.

Interest of the associations in workers training: This refers to the inclination of employer associations towards worker training. We attempt to ascertain the utility of this type of training for the interviewees and the employer associations, exploring the vocation that they feel for it.

General perception of worker training: In this category we look at the interviewees' opinions of Lifelong Learning and worker training from the perspective of the time. By this we mean the general perception of the current VET system since it appeared in 1992.

Axial Coding. At this stage of coding, a selection of the most relevant categories was conducted, either by the number of text sections encoded or by the importance of the information, to subject them to further elaboration or explanation. In other words, "what happens in them," is explained, describing the conditions that cause the different phenomena, its contexts and consequences.

A number of substantive theories was also generated from the quotes of the text. If we understand these as theories with a status of temporariness, which does not become a formal theory, but only has a preliminary conceptual function, then that in turn can serve to create a formal theory.

The categories that were further analysed in this section are the following:

- Purpose of worker training

- Purpose of training funds

- Interest of the Associations in worker training

- Bad practices

- Reason(s) to choose training in an employer association

- Unions and trade organisations

- Situation of the VET in Spain and policy changes

- General perception of worker training

The following is one of the many quotations that were commonly used to support the substantive theories that we were formulating with our data. Through this quote, among many others, we were working on the category "Interest of the 
associations in worker training." As we can see here, the interviewee, president of an employer association, states that the economic structure of the employer associations has not just been based on the quotas that the associated companies pay, but also on sponsors and on the training budgets themselves. It is also deduced from this interview that the employer associations have created big, heavy structures outside their economic means, as they have been largely financed by money from training. Therefore, one of the empirical findings that came out of the analysis of the interviews is the following: The employer associations have been financed by training funds, leading to a growth in the volume of their staff and structures.

In the end what has occurred is that, after so many years, the budget structure of the business organisations has been sustained by a series of variables such as quotas, sponsorships, but also by the training budget itself. I insist that the training budget is supporting training structures but heavy training structures. What is happening now is that there are business organisations in Spain that, having invested in great training structures, and having reduced their budget, are not able to financially support this issue and this in turn is affecting the accounts of the organisation. (Interview with the president of the Association of e-learning Suppliers).

In the following quotes related to the category "Situation of the VET in Spain and policy changes" one can appreciate how the interviewees think that the government is making important changes without a previous consensus. This is something that is not shared by the social agents who view the new model as the end of many years of quality training. It is as if they thought that the training framework that the government is thinking of was going to end the VET as we have known it until now in Spain. From the interview it is deduced that the government mistrusts the trade unions and the employer associations, thinking they do not work honestly.

It can also be deduced that they perceive the trade unions and employer associations as if they were not qualified enough to have an opinion on the topic.

The new framework worries me because I think it is the beginning of the end. I think that the budget cuts will get bigger and bigger, and the social interlocutors are going to be ignored more and more. I think that what the public administration is going to achieve with the new system in the end is completely atomise the market. (Interview with the Director of CEOE Formación)

It is not a lot more than that; it is a certain mistrust that exists, (...) I do not know how to express this to you: When the administration does not have a counterweight, it uses its own criteria, thinking that its own criteria is fair and everyone else just does not know; that everyone else is just out for their own particular interests while it is looking out for the general interest. That is their speech and before you realise it, they have taken everything. (Interview with ex-minister of work of the government of Spain and president of AEC) 
It seems as if the government has been using training to "struggle for power" or punish the business associations and the trade unions, not allowing them to access those funds in the same way they have until now. Thus, training becomes a political tool.

It benefits the power, the current government, I am convinced that it is a power struggle and that is why it seems very cut and thrust, now that we are suffering collateral damage or punishments that they want to give to certain social agents ... Therefore, they are political tools. That is why they have used training as a tool and not as an objective, and this says a lot about those who are doing it ... They don't know anything about training, they know about administration but not about training - with all due respect. (Interview with the Chief Learning Officer of FEDETO)

In relation to the category "bad practices", it is revealed that there has been fraud in diverse estates, from the level of private employers, to business associations, trade unions and the autonomous governments. This has led to a perception that things have been badly handled. Below you can see some of the quotes that support this finding:

In the private sphere we know which organisations commit fraud and which don't. It is also true that in the private sphere there are many organisations and training companies that entered into a trap from which it is now difficult to get out of and say who was responsible for what, because then they would have to expose themselves. Moreover in the private sphere, I insist, that the practices in the private sphere are the ones I just said, and I am not generalising, they are happening and everyone can see it; you can see it in the comments of many suppliers that come here and they say, in which margins other organisations are, for example trade unions, asking for money to be returned, and probably some business entities - I'm not ruling them out. (...) (Interview with the Chief Learning Officer of FADE)

Also the public administration has made, according to the interviewees, bad use of the funds. Instead of using them for training, it has used them for other types of activities. This means corrupt use of public money for political means. In the following quote we can appreciate how the previous president of the autonomous government of Madrid decided to unilaterally take the funds from professional training and use them for encouraging entrepreneurship instead of training:

(...) The ex. president but new president has confirmed where the funds have gone, and she has used them not to train employed workers which is the main objective, not to train unemployed workers, which is an objective derived from the previous one, but towards entrepreneurship (Interview with the Training Director of CEOE)

Selective Coding. The last phase of the study consists of identifying a core category around which the others organise and integrate themselves. 
In order to facilitate the formulation of the theory, which is based on empirical data from the interviews and the subsequent analysis performed at the Open Coding and Axial Coding, we rely on the Conditional Matrix that appears in Figure 1, in which all the concepts and ideas are grouped around what we consider the core problem or the core category: "Current Situation of the VET System."

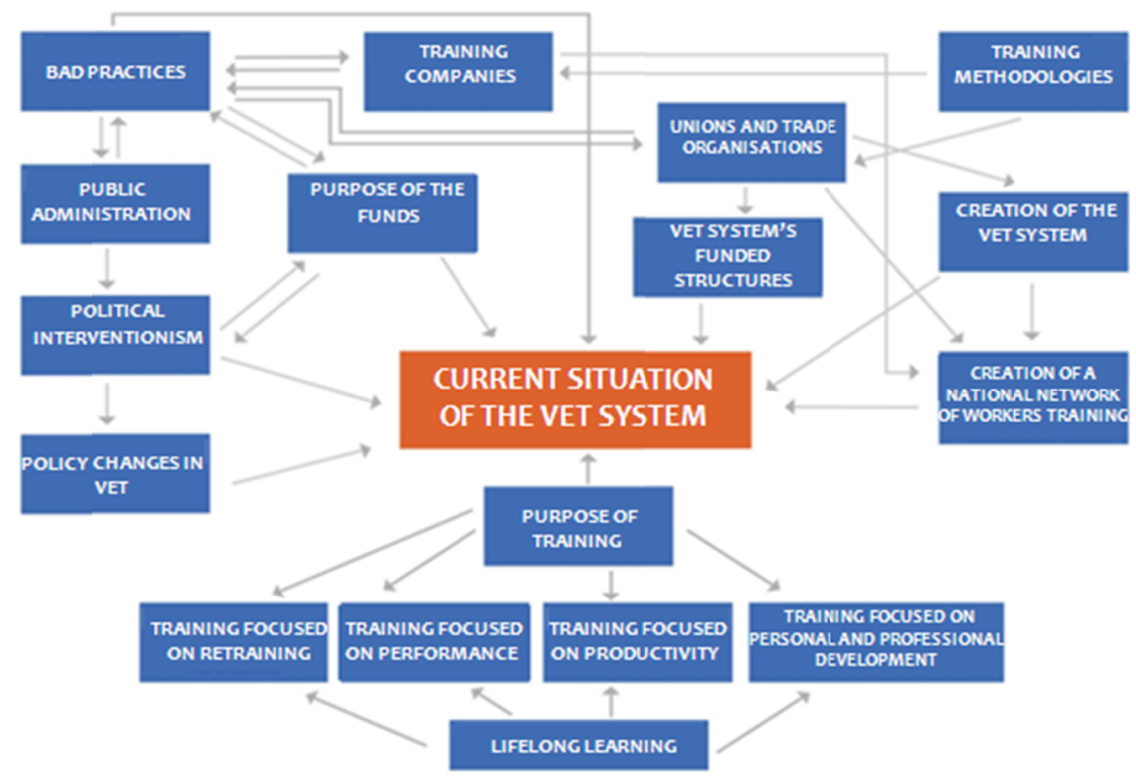

Figure 1. Conditional matrix

From the empirical data of this research, of which we have just seen some examples, we can deduce what the current situation of the VET System is according to the personal views of the interviewed people. As we can appreciate in figure 1 the current situation has been influenced positively from the beginning, by the creation of a National Network of Workers Training that was formed thanks to the trade unions and employer associations that created the VET System.

The interviews have also shown how the structures of these associations have been maintained thanks to training funds, which is not justifiable, and has led them to be involved in bad practices. Training companies that give services to trade unions and employer associations delivering these courses have also carried out these bad practices. The public administration has also undertaken bad practices, including changes in the VET policy in a unilateral way, without consulting with the trade unions and employer association, with a clear political agenda: to control how worker training should be carried out. 
Another important factor is that the funds meant for training have not been used for their original purpose, but for other less justifiable issues. Finally, the purpose of training, that according to the interviewees should be focused on retraining in performance, productivity and personal and professional development, influences positively on the VET system.

\section{CONCLUSIONS}

As it has been shown, the interest of the employer associations in worker training has been a question, amongst others, of money, since developing training programmes brings in funds which can support their large structures. Therefore, worker training has been used in order to finance business organisations. Furthermore, according to the interviewees, there is a certain amount of governmental mistrust towards the trade unions and the employer associations, which has led them to create a new model of VET without their participation. Another important point has been that of the misuse of training funds which the majority of stakeholders have all carried out at one point or another. Thus, training has received bad press in society as a whole.

As we mentioned in the research aims, we wish to undertake a critical analysis of this situation. Firstly, one of the contradictions between a system that is presented as an attempt to organise participative worker training, taking into account the interests of both employers and employees, but which in the end seems only to satisfy the interests of large employers. Nor does it appear to take into account the fact that training processes are, fundamentally, educational processes in which adults participate.

Secondly, another issue is related with the aim of the training itself. For example, according to Ettore Gelpi work training should be carried out at workplace and should be based on the experience that the employees have garnered from their own work experience. Therefore, training and learning should be entwined with people's daily lives. He referred to this as work cultures (Gelpi, 2004), and to the pride of doing a job well. Similarly, as Sennett pointed out with the example of the Boston bakers (Sennett, 2000) or how various authors have studied, using the concept of Aristotelian rhetoric, in the case of specific professions such as teachers (Elliot, 1986; Schwab, 1968). Nothing about these questions which go beyond the instrumental learning, or the idea of training to keep oneself employable (in the case of unemployed persons) or increase competiveness, seem to be present in the previous discourses. What is more, it is not present because training has been used for different ends, as is being demonstrated at the moment by means of the courts' investigations.

The scant usefulness of this training is borne out by the example presented below, and which comes from previous research in which one of the authors of this study participated (Lucio-Villegas \& Fragoso, 2003) and which refers to young adults. These young adults seem to develop a process we call "the perverse circle." They leave school either prior to or at the end of compulsory education (16 years), to work in agriculture in spring and in tourism in summer. After summer, 
they move from short periods of diverse jobs to periods where they ask for unemployment benefits. This circular situation of sub-employment/unemployment assistance is kept up for six to eight years, a period in which young adults do not study at all. At the end of this period, during which they learn about the harsh realities of work 'they have learned their lesson, they know how the land lies.' Facing the necessity for some personal/professional stability, they apply to local professional training resources, aiming to turn their situation around. It is important to stress that the large part of this labour cycle works in hidden economy (there are no contracts nor social security contributions, etc.). This increases the spectrum of uncertainties that young adults experience regarding their futures, and constrains their personal development. But the most perverse element of this scenario is the fact that a great number of young adults do not escape from the networks of this cycle. They remain in a drastic situation. They do not apply for training programmes. The harm caused by a lost education is worsened by all the troubles they find in labour market integration, and to integrate into an active lifestyle where social assistance needs are meaningless. However, even the young adults that attended this training ended up joining the unemployment lists, because work and employment do not depend entirely on training and learning, but also on the dynamics of the labour market, which appears to be creating, by way of training processes, what Marx referred to as a tireless reserve army of labour.

\section{REFERENCES}

Billett, S. (2001). Learning in the workplace: Strategies for effective practise. Sydney: Allen \& Unwin.

CEDEFOP. (2011a). Learning while working. Success stories on workplace learning in Europe. Luxemburg: Publication Office of the European Union.

CEDEFOP. (2011b). Shaping lifelong learning: making the most of European tools and principles. Briefing Note. Thessaloniki: Publication Office of the European Union.

Elliot, J. (1986). Autoevalución, desarrollo profesional y responsabilidad. In M. Galton \& B. Moon (Eds.), Cambiar la escuela, cambiar el currículo (pp. 237-259). Barcelona: Martínez Roca.

Flick, U. (2012). Introducción a la investigación cualitativa. Madrid: Ediciones Morata.

Forrester, K. (2007). Exploring understandings of labours, learning and democracy: A British case study. In E. Lucio-Villegas \& M. C. Martínez (Eds.), Adult learning and the challenges of social and cultural diversity: Diverse lives, cultures, learning and literacies (pp. 63-76). Proceedings of the $5^{\text {th }}$ ESREA European Conference, Vol 3.

Gelpi, E. (2004). Trabajo futuro. La formación como proyecto politico. Xâtiva: Edicions del CREC.

Glaser B. G., \& Strauss, A. L. (1967). The discovery of grounded theory: Strategies for qualitative research. New York: Aldine.

Lucio-Villegas, E., \& Fragoso, A. (2003). Literacy, adult education and social change in southern Europe: A case study. In D. Flowers, M. Lee, A. Jalipa, E. Lopez, A. Schelstrate, \& V. Sheared (Eds.), Proceedings of the 44th Annual Adult Education Research Conference (pp. 261-266). San Francisco, CA: San Francisco State University.

Olesen, H. S. (2007). Professions and vocations. Collective work identities in late modernity. In E. Lucio-Villegas \& M. C. Martínez (Eds.), Adult learning and the challenges of social and cultural diversity: Diverse lives, cultures, learnings and literacies (pp. 15-33). Proceedings of the $5^{\text {th }}$ ESREA European Conference, Vol 2. 


\section{R. M. HERNÁNDEZ CARRERA \& E. LUCIO-VILLEGAS}

Rauner, F., \& Maclean, R. (2008). Handbook of technical and vocational education and training research. Dordrecht: Springer.

Schwab, J. (1969). Un enfoque práctico como lenguaje para el curriculum. In J. Gimeno \& A. Pérez Gómez (Eds.) (1985), La enseñanza: su teoría y su práctica (pp. 197-209). Madrid: Akal.

Sennett, R. (2000). La corrosión del carácter. Madrid: Anagrama.

\section{Rafael M. Hernández Carrera}

Faculty of Education

International University of La Rioja, Spain

\section{Emilio Lucio-Villegas}

Faculty of Education

University of Seville, Spain 


\section{GOVERNING VOCATIONAL EDUCATION AND TRAINING IN EUROPE}

\section{INTRODUCTION}

Since its founding on 18th April 1951 as the European Coal and Steel Community, the European Union has been pursuing three key objectives: peacebuilding, fostering social coherence and creating a common European economic area. It is this latter aspect in particular that has led to the repeated 'discovery' of vocational education and training (VET) as a policy area, promising, as it does, to qualify people for an occupation suited to their abilities and talents and thereby enabling them to participate in the labour market sustainably. VET thus makes a significant contribution to achieving the objectives of the EU.

In general, the aim of European VET policy dovetails with that of national VET policies: its primary aim is to equip learners with vocational skills and knowledge and to enable individuals to receive and remain in an occupation and in gainful employment. However, the EU and its Member States hold different views on how to provide and structure occupations and qualifications and on how to govern VET. This situation is further compounded by linguistic, disciplinary and culturalhistorical peculiarities at the level of individual Member States and is imprinted by a bewildering variety of actors at both the national and European levels. In Germany, e.g., the educational landscape is characterised by the division into federal and state levels, with all their parliaments, parties, ministries, lower-level institutions, representatives, committees, chambers, trade unions, associations, academic societies, etc.; at the European level, education policy is influenced primarily by the Council of Ministers, the European Council, the European Commission and the European Parliament, but also by the relevant agencies (particularly the CEDEFOP and the ETF), the Commissions, the European Court of Justice and not least the vocational education lobbies.

The aim of this article therefore is to outline European VET policy, including principles and instruments of governance, and to scrutinise the extent to which EU policy impacts on national VET policies for which I choose Germany as a paradigmatic case due to its dual apprenticeship system and its strong orientation on occupations (Berufskonzept). 


\section{MAPPING THE FIELD}

Traditionally, VET focuses on various forms of labour-market relevant education and training. In Germany, VET and VET research are dominated by a publicprivate partnership VET type known as the dual apprenticeship system. Since VET is per se located at the interface between the education system and the labour market, it is mainly dealing with the aims, conditions, opportunities and realities underlying the qualification pathways of individuals (primarily adolescents) by means of (mostly institutionalised) measures (which tend to exclude higher education) to enable them to engage in gainful employment and to participate in society.

If VET constitutes a complex area, this is all the more true of policy formation in this area because it is at the crossroads between education, economic and social policies.

With regard to the terminology used in the political arena, the academic discourse offers a variety of competing notions intended to capture the essence of political action. Examples include

- governmental vs. emancipatory conceptions of politics ('statesmanship'; sovereignty and authority vs. power limitations through participation and democratisation);

- normative vs. descriptive conceptions of politics (notions of public welfare serving the interests of social harmony vs. binding rules and regulations on social values);

- conflict-oriented vs. consensus-oriented conceptions of politics (class conflict vs. harmony-oriented concepts of politics) (Alemann, 1994).

However, there is no single conception that takes account of all these facets. This is why, since the 1970 s, political science has largely abandoned attempts to describe the true nature of politics in favour of accounts of what politics and/or particular policy areas are about. Policy analysis seeks to answer the question 'what governments do, why they do it, and what difference it makes' (Dye, 1978, p. 3). This involves adopting a system-theoretical perspective to analyse policy in terms of three dimensions: institutional (polity), substantive (policy) and processual (politics). In this perspective:

- Polity refers to the forms or formal dimension of political life, i.e. state structures, measures of compliance and conditions underlying political action as well as the relevant norms and institutions. Polity is the prerequisite for policy and the result of and the prerequisite for social change. With regard to VET policy, polity comprises the constitutional environment in which VET takes place and the laws, rules and regulations that govern it.

- Policy refers to the content of political decisions (policy areas), i.e. causes, aims and effects of political activities. The analysis of such policy areas (e.g. health, education, and social policy) is conducted from the perspective of the actors involved. Thus, VET policy comprises areas and problems associated with structuring, organising, planning and managing VET.

- Politics refers to the processes involved in representing and mediating between social, institutional and individual interests and resolving conflicts arising from 
them. Thus, VET policy comprises those (decision) processes ('power struggles') which concern the organisation and planning of VET, i.e. which constitute an attempt on the part of national, supranational and nongovernmental entities to wield instruments of political power with a view to making collectively binding decisions (Kutscha, 1997, p. 649).

In practice, however, these three dimensions can be distinguished only analytically, de facto, they overlap and are interdependent. This is also true of the closely related term 'governance', which, in political science, is taken to refer to a 'secularised' notion of the exercise of political power that reduces the latter to its objective and technical dimensions, thus competing with the normally broader, related terms of 'government' or 'governing'. With regard to issues concerning education policy, the term covers the 'intentional coordination of action with a view to organising society in accordance with the general interest' (Scharpf, 1988, p. 64). Accordingly, the governance of VET involves political actors and institutions designing and organising an environment for (vocational) education policy at national and supranational levels as well as providing the theoretical, empirical and normative basis for such an environment. While theories of political action refer to the policy process, governance itself aims at policy making. Political science has developed numerous categories for policy analysis which are essentially intended to explain governance and the possibilities, logics and instruments associated with it. The most important of these serve the distinctions between

- distributive, redistributive, regulative and self-regulative policy types according to Lowi (1972);

- principles of governance and instruments of governance (Windhoff-Héritier, 1987; Howlett \& Ramesh, 1993);

- general policy aims (paradigms and fundamental beliefs), instruments of governance and the adjustment or modification of instruments of governance (Hall, 1993; Sabatier, 1993);

- policy tasks that actually provide solutions, that are complex and that are divisible, where instruments and principles of governance need to be adapted to the respective policy task types (Peters, 2005); and

- structuralist approaches to explaining factors which influence the organisation of policy areas, (macro)actor-theoretical approaches and approaches in institutional economics (Scharpf, 2000; Lauth \& Thiery, 2009).

None of these approaches can provide a full account of political life and governance; rather, the ways in which they are implemented and their explanatory power depend on specific research questions and perspectives. In what follows, I will show how these approaches can help explain how the EU's principles and instruments of governance are used in the areas of VET and where additional approaches are needed.

While there is a large body of research on VET per se, few studies deal with the governance of VET at the crossroads between national interests and European integration (e.g. Bohlinger, 2008; Münk, 2006). Unrelated to these, numerous studies exist in political science on the political governance and governability of 


\section{S. BOHLINGER}

the European Union (e.g. Jachtenfuchs \& Kohler-Koch, 2004; Scharpf, 2003; Szukala, 2012); however, these give no, or very little, consideration to VET. Hence, the gap between these two fields of research refers to the question 'who governs what, how and why in the European VET policy area?'. This deficit stems from the fact that the development of the EU as it impacted the nation states has long played a minor role in political science and educational research. Far into the 1980s, (vocational) education had been a rather marginal policy area in the EU, remaining, in accordance with the 1957 treaty establishing the European Economic Community (EEC), at least de jure under the sovereignty of its Member States.

However, the scant attention that is being devoted to the subject is not commensurate with its actual impact and implications and there is evidence that VET is massively, if indirectly, ruled by the EU, although at least in theory it is under the sovereignty of its Member States.

\section{POLICY AIMS AND GOVERNANCE PRINCIPLES}

Since it was founded, the European Union's general policy aims have been peace building, economic development and social coherence, i.e., the convergence of living standards. To this day, the instruments of governance and their permanent modification and adaptation follow the seemingly simple logic of implementing these aims. In order to attain them, the Union over the course of decades has expanded its authority over numerous other socio-political areas. The Union's cornerstones are the Treaties of Rome that govern free movement of persons, services, capital and goods. It is particularly the freedom of movement of workers, which, under Article 48, warrants

the abolition of any discrimination based on nationality between workers of the Member States as regards employment, remuneration and other conditions of work and employment.

Granting these four basic rights is at the core of European policy, building its operational and governance logic. Starting from this logic, the central governance principle of European policy that, directly or indirectly, touches on VET and which essentially derives from the Treaties of Rome, i.e., from the subsidiarity principle and the prohibition against harmonisation, begins to make sense.

European policy accordingly followed the guiding principle of harmonisation and convergence of VET systems well into the 1960s as pointed out by a Council Resolution dated April 2, 1963 which promulgated general principles for a common VET policy. Amongst them, we find:

The common vocational training policy must, in particular, be so framed as to enable levels of training to be harmonised progressively. [...] the Commission shall [...] draw up in respect of the various occupations which call for specific training a standardised description of the basic qualifications required at various levels of training. On this basis, harmonisation of the standards required for success in final examinations should be sought, with a view to the mutual recognition of certificates and other documents 
confirming completion of vocational training. (Council of the European Economic Community, 1963; author's italics)

However, a convergence of VET systems turned out to be unrealistic, since VET does not affect the free movement of workers directly but only indirectly (and, in a larger sense, also the free movement of services). Consequently, during the 1970s, the EEC turned away from the idea of harmonisation and convergence leading to e.g. the Dahrendorf Memorandum of 1973 stating the harmonisation of education systems as neither realistic nor necessary and instead sketching the elaboration of the educational policies of the national states as the Union's key mission going forward.

Ever since we can observe the development and expansion of measures and programmes (e.g. Erasmus Plus, Leonardo da Vinci, Erasmus, Comenius) for establishing a European Area of Lifelong Learning while simultaneously acknowledging the variety of national qualification pathways and structures. They comprise nearly all areas of general, vocational and tertiary education as well as cooperative ventures with non-European partners, and voluntary participation by Member States is at the core of all programmes.

The key principle of this strategy, i.e., subsidiarity instead of harmonisation, in the meantime has become enshrined in the agreement: within the framework of the EU treaties, the subsidiarity principle found its way into the Single European Act (SEA) as Article 130. It became the foundation of European policy when it was taken up into the Maastricht Treaty, and it recurs in the Nice Treaty in Article 149. It states that the Union will only be active within the limits of the authorities and stipulated aims allowed it under this treaty. In areas not under its exclusive jurisdiction - such as VET - the Union will only become actively involved according to the subsidiarity principle if and when the aims or measures being considered cannot be achieved satisfactorily at the Member State level because of their scope or impacts and hence are more suited to implementation at the European Union level.

By now, VET as a policy area has clearly taken on shape and dynamism: for the first time in the history of EU summits, VET was proclaimed a strategic goal as part of the Lisbon Strategy. Its goal is to 'to become the most competitive and dynamic knowledge-based economy in the world capable of sustainable economic growth with more and better jobs and greater social cohesion' (European Council, 2000). Of the roughly 80 indicators that were regularly used to monitor the realisation of the Lisbon Strategy, five cover (vocational) education and training, another 20 were developed in the framework of the work programme 'Education and Training'. They included, among others, adult participation in lifelong learning, qualifications of adults, language skills, and professional development of teachers and trainers (European Council and European Commission, 2002). This programme captured the aims for the entire educational area agreed to by the countries and the Union as a way of fulfilling the Lisbon Strategy. Against this background, the Bruges-Copenhagen process for VET that started in 2000 and the Bologna process for higher education that started in 1998 with the Sorbonne Declaration seem to serve solely to implement the two general policy strategies. 


\section{S. BOHLINGER}

In the follow-up strategy Europe 2020 (European Commission, 2010), the role of (vocational) education and training was again emphasised and declared a strategic goal (European Council, 2009). Key contents of the current 'Education and Training' work programme are e.g. creating a European lifelong learning area, improving the transparency and mutual recognition of qualifications, and expanding VET at post-secondary levels (European Council, 2009).

The variety and substantive range of these aims clearly mark the Union's attempts to impact on VET in order to implement the Lisbon Strategy and Europe 2020. Among the multiplicity of 'recommendations' for national implementation that have been conceived concomitant with both strategies are to be found the Europass, the European Qualifications Framework (EQF), the European Credit Point System for Vocational Education and Training (ECVET), validation principles, learning outcomes orientation and more. Here, it is worth analysing what instruments the Union uses to regulate this area in order to ensure that the member countries do in fact follow the Union's recommendations.

\section{GOVERNANCE INSTRUMENTS}

In addition to the basic treaties (so-called primary law), the European Union has developed five additional legal instruments, called unilateral acts which are part of the secondary law. Table 1 first provides an overview of these legal regulations, with the discussion of each following the table.

Table 1. Five forms of EU law (Article 288 of the Treaty on the Functioning of the EU)

\begin{tabular}{|c|c|c|}
\hline Description & Scope & Examples related to VET \\
\hline Regulations & $\begin{array}{l}\text { General validity; all their parts are } \\
\text { binding on every Member State }\end{array}$ & $\begin{array}{l}\text { Regulation (EU) No. 1304/2013 } \\
\text { on the European Social Fund } \\
\text { (ESF) (European Parliament \& } \\
\text { Council of the European Union, } \\
\text { 2013) }\end{array}$ \\
\hline Directives & $\begin{array}{l}\text { With regard to the objective to be } \\
\text { achieved, binding on each Member } \\
\text { State to which directed; however, } \\
\text { the intra-state authorities may } \\
\text { freely choose forms and means for } \\
\text { their implementation }\end{array}$ & $\begin{array}{l}\text { Directive } 2005 / 36 / \mathrm{EG} \text { (directive } \\
\text { on the recognition of } \\
\text { professional qualifications) } \\
\text { (European Parliament \& } \\
\text { Council of the European Union, } \\
2005 \text { ) }\end{array}$ \\
\hline Decisions & $\begin{array}{l}\text { Binding in all parts for all those } \\
\text { designated }\end{array}$ & $\begin{array}{l}\text { Decisions by the European } \\
\text { Court of Justice (ECJ-Blaizot, } \\
1988^{1} \text {; ECJ-Gravier, } 1983^{2} \text { ) }\end{array}$ \\
\hline Recommendations & Non-binding & $\begin{array}{l}\text { Recommendation on the } \\
\text { Establishment of European } \\
\text { Qualifications Framework } \\
\text { (European Parliament \& } \\
\text { Council of the European Union, } \\
\text { 2008) }\end{array}$ \\
\hline Opinions & Non-binding & $\begin{array}{l}\text { Opinion on growth promotion } \\
\text { (European Council, 2012) }\end{array}$ \\
\hline
\end{tabular}


Depending on their bindingness and scope, most of the instruments are listed in Article 288 of the Treaty on the Functioning of the EU (regulations, directives, decisions, opinions and recommendations), communications and recommendations (as well as white and green papers) are not listed in Article 288 of the Treaty on the Functioning of the EU.

\section{Regulations}

The Council and Parliament issue binding regulations upon recommendation by the Commission (and after committee hearings) for areas that under treaty law are to be governed Community-wide. Since VET falls under the sovereignty of the Member States, the Union cannot issue regulations that directly affect VET, such as a regulation on VET financing or VET structures. However, numerous regulations impact on VET indirectly, as in the case of the ESF:

In order to facilitate a manageable approach to its integration into the programming process, the community-led local development can be carried out under a single thematic objective, either to promote social inclusion and combat poverty, or to promote employment and labour mobility, notwithstanding that actions financed as part of community-led local development could contribute to all other thematic objectives. (European Parliament \& Council of the European Union, 2013, author's italics)

Consequently, regulations such as the ESF offer the opportunity for indirect rule of national VET systems. The control is exerted via financial incentives for policy measures and programmes; for example, in the case of combating youth unemployment, with approximately 10 billion Euros annually (for all member countries), where all subsidised means require a national contribution of $15-50 \%$ per measure.

Following the classification of policy types by Lowi (1972), regulations seem to be a distributive policy that stimulates taking appropriate steps and that is consensual to the extent that all Member States can basically identify with the ESF's general aims. On closer examination, however, this policy type is also a redistributive one since the available funds are limited and because here a de facto selective performance grant is made that, in turn, is tailored to a structural weakness or strength of a region, to the (presumed) utility of planned measures and to the fit of the planned measure with investment priorities. The effectiveness of this steering mechanism is revealed by the ESF's investment priorities and conditions for the current 2014-2018 funding period, some of them with a clear focus on VET:

- adaptation by workers to economic change (measures for proactively and successfully dealing with change and restructuring);

- measures to support (transnational) labour mobility and improve employability;

- measures to widen access to lifelong learning through implementing transparency tools (EQF, ECVET, European Quality Assurance in Vocational Education and Training); 


\section{S. BOHLINGER}

- measures to improve the labour market relevance of education and training (European Parliament \& Council of the European Union, 2013).

Aligning the priorities with the Union's general aims can be recognised here just as clearly as the motivations of the Member States to participate: whoever falls into line with the supranational priorities, receives subsidies. However, if the longstanding criticisms of the ESF are to be believed, these subsidies are made regardless of whether the subsidised subject areas truly are national problem areas and whether or not the steps taken are in fact effective or if, the problem areas persist only - not having shown perceptible improvement after more than 50 years of ESF existence - because the regular, assured subsidisation by the ESF has prevented a genuine solution (Barnier, 2003; Rodriguez-Pose \& Fratesi, 2004).

\section{Directives}

Directives in respect of their intended aims are binding on every Member State, although the choice of means and forms for implementation of individual directives is left to the Member States. For example, the directive on the recognition of professional qualifications refers to recognition of so-called regulated professions and applies to all citizens of European Union (EU) Member States, of the European Economic Area (EEA) and of Switzerland who have obtained their qualification in a Member State. It guarantees them access to these professions on the same terms as nationals. It came into force in 2005 and had to be codified in national law within two years. It, too, follows the logic of granting of the four basic freedoms, i.e., specifically the freedom of establishment for workers. This directive is first of all a regulative policy type, in that it represents a rule of conduct for all abovementioned states. But it is simultaneously constitutive, in that its application can lead to potentially significant changes in professional and occupational regulations, as, for example, those covering almost all caregiving and health occupations and most of the medical professions.

The catalogue of regulated occupations comprises approximately 5,000 for all affected states (EU, EAA and Switzerland), with some 150 for Germany alone. Regulated occupations are subject to so-called professional and occupational licensing regulations, i.e., each of these occupations is covered by its own law that regulates under what conditions someone practicing a profession is entitled to hold the professional titles and certifications. However, for my purpose here, what type of prerequisites is stipulated for which occupation (minimum duration, responsible authorities, etc.) is less decisive than why these directives were introduced. Indeed, in articles 2 and 4 of the regulation it states:

[...] the Commission adopted a Communication [...] aimed in particular at making the free provision of services within the Community as simple as within an individual Member State. [...] the European Council [...] entrusted the Commission with presenting [...] specific proposals for a more uniform, transparent and flexible regime of recognition of qualifications. [...] In order to facilitate the free provision of services, there should be specific rules 
aimed at extending the possibility of pursuing professional activities under the original professional title. [author's italics]

Again, Directive 2005/36/EC serves the implementation of the Lisbon Strategy or, more generally - the creation of a common European economic area, and follows the logic of granting the free movement of workers and service. The same directive also provides us with numerous references to the development of the EQF and a summons to develop more national rules and procedures for accelerating the recognition of occupational qualifications - an invitation that, in the meantime, has in fact been followed up on in e.g. Germany with passage of a law for improving the recognition of foreign professional and vocational qualifications. As an umbrella law, it covers not only Directive 2005/36/EC, but also the Vocational Qualifications Assessment Law and all relevant amendments to the Vocational Training Act, the Skilled Craft Act and 63 additional occupational regulations (BMBF 2012).

Even if Directive 2005/36/EC does not directly impact on VET, it very much rules indirectly under what conditions specific vocational qualifications and professional titles may be awarded or claimed. Thus, ideally, the Directive takes on a protective function for EU nationals and simplifies their access to the Union's internal labour market. However, because it supersedes national law, the downside is that it can block adaptations of qualifications and reforms that are meaningful, important, and appropriate for a nation state.

\section{Decisions}

Decisions by the European Court of Justice (ECJ) play a significant role in VET and national VET policies. Over the past decades, the ECJ has time and again interpreted the European Union's authority expansively; while concurrently it has left untouched the principle that the organisation of the entire (vocational) education and training system and (vocational) education and training policy in and of themselves do not fall within the Union's purview. The case law itself once more follows the logic of the four basic freedoms granted by the Rome Treaties.

In this context, the Blaizot and Gravier cases, which, for the first time, brought students within the scope of professional education, can be regarded as precedentsetting. Previous to that, anyone who moved to a different country to take up studies was not able to derive any rights from the freedom of movement of workers (e.g. with respect to tuition fee waivers). Ever since these two decisions, any education at universities can count as professional education, which has considerable effects on tax rules, tuition, grant schemes, etc., and it has substantially accelerated the blurring of the line between occupational and academic education.

The full scope of these rulings, however, first becomes evident from further rulings, as illustrated by the following instance: in Austria, university degree programmes are free to all high school graduates. This led to a large number of German high school graduates taking up their studies in Austria, because their final 


\section{S. BOHLINGER}

exam scores were insufficient for admission to university premed courses under German numerus clausus rules. This in turn caused Austria to adopt a regulation that let foreign nationals study medicine in Austria only if they could demonstrate that they were also sufficiently qualified to study medicine in their home country. Consequent to this, the European Commission started a treaty infringement procedure (key word: infringement on the freedom of establishment). The European Court of Justice concurred with this objection per Article $22 \mathrm{EU}$ - with the result that in subsequent years more than $60 \%$ of all applicants to some Austrian medical faculties came from Germany. At the same time, it was the starting point for a European-wide wave of selection procedures at universities (Rechnungshof, 2007, p. 97ff.; Scharpf, 2009, p. 264).

To begin with, the crucial point here is that the proceeding was possible only because degree programmes were ruled to be professional education and that therefore treated students as workers. But the example also illustrates how expansively the Court interpreted case law in favour of Union interests and neglected the consequences for the national states:

[Thus] the Court decides which national policy goals even qualify as 'compelling requirements of the public interest'. Fiscal concerns, for example, fundamentally are not taken into account. Hence, in the [...] Austria decision, the consequences of the massive influx of German students on university budgets were totally ignored (Scharpf, 2009, p. 267);

and, further with regard to this example, while the Court

at least contemplated that the danger of overcrowding of the Austrian universities could be an acceptable justification, this idea was quickly discarded on the grounds that the problem could also be solved through nondiscriminatory entrance examinations. The fact that Austria ought to give preference to its own students in order to raise the enrolment rate - low by international standards - and in order to train a sufficient number of practicing doctors for the Austrian health system, a priori was not accepted as a legitimate argument. (Scharpf, 2009, p. 269)

More than for any other governance tool, it clearly emerges here that Court decisions de facto have regulative and constitutive character. Their binding character is so high that - to date - in no case they could be reversed (i.e. voided by a new ECJ decision). As a consequence, national interests as they concern VET are undermined in places where the Union essentially has no right to intervene.

\section{Recommendations and Opinions}

Recommendations and opinions are non-binding and cannot be assigned to any of Lowi's four policy types. At best they could be regarded as being distributive, namely when resources are offered to the Member States as incentives to follow them. Hence, programmes like Lifelong Learning or Erasmus Plus are crucial: they may not be among the governing mechanisms in the legal sense and participation is 
voluntary, but they do offer participation incentives that are in line with the same logic as the recommendations and opinions, such as those fostering worker mobility.

Whereas Council (and Parliament) opinions mostly are encountered in EU foreign policy and opinions issued by the Commission serve as decision support for the Council and the Parliament, recommendations by the Council and the Parliament produce the paradoxical situation that they end up - despite their recommendatory nature - in most cases being implemented by all countries. In the above-cited example on the EQF recommendation we can observe that even countries, which, for a long time, had critically questioned the added value of the framework, ultimately fell in line with the recommendation - a fact that emerges from the annual country reports covering VET, which the CEDEFOP had the national states routinely prepare in the context of its annual European Research Overview.

Due to the reporting requirements to Union agencies, it also becomes clear why the nation states eventually sign on to the recommendations despite the criticism leveled against them: In the wake of the Lisbon Strategy, the states had agreed to develop instruments for promoting transparency; the recommendation by Council and Parliament to establish the EQF hence simply served to aid the countries in realising this aim. The example also shows that countries that do (not) abide by a recommendation are named in the yearly progress reports, together with their specific state of development, and thus are not only exposed to public view but can also suffer painful hits to their reputations.

Moreover, implementing the recommendations seems to neither incur obligations nor costs, it appears to be reversible at any time or - as in Germany - it leads to the development of parallel systems. This could happen when existing legal rules (such as tariff law, university admission rights, etc.) remain in force parallel with a national qualifications framework and designated qualifications are therefore treated differently depending on which system is used.

\section{CONCLUSION: AREAS OF TENSION AND PROBLEMS OF LEGITIMACY}

In summarising the governance instruments and principles in European VET policy, we may at first think that we can detect a clear limit on the implementation of the four basic freedoms coupled with a distinct national sovereignty. This could lead to the assumption that Europe in practice comes off as far removed from VET research, policy and practice at national levels.

However, a second look leads to the recognition of a steady expansion of European Union law based on two governance tools that by now have assumed the character of governance principles, namely:

- an expansive interpretation of European Union law, in which the grant of the four basic freedoms coupled with individual situations or cases is nearly unconditionally elevated above national interests; and 


\section{S. BOHLINGER}

- a permanent and publicly accessible reporting mechanism progress monitoring, through which the nation states document their progress toward realising common aims.

The Union's expansionist moves consequently warrant closer study, as they critically do affect VET. Still, the expansionist efforts directed at VET are, because of the drawn-out implementation process, as difficult to discern as their consequences are difficult to size up. The scope, costs, and consequences of the European policy frequently only attract attention when adapted to national circumstances, so that the nation states frequently find themselves endorsing

political costs of European policies that they had absolutely no, or little, chance to influence during the phase of their formulation. (Szukala, 2012, p. 203)

These expansionary moves are difficult to grasp applying the traditional political science approaches only since they relate less to formal legitimacy (legality) and instead much more to the nation states' trust in the legitimacy of European policy actions. The legitimacy of the utilisation or the interpretation of the governing principles and instruments meanwhile appears questionable. This holds especially true for the Court's decisions that, because of their binding force, have changed the national VET policies and landscapes more than any other governing instrument. Scharpf is correct in concluding that 'so the European case law [...] [undermines] solutions by individual states, without any alternatives available on the European level. The practical consequence is diminishment in political problem solving capacity particularly in policy areas that are of critical importance for the daily lives of citizens and their legitimacy relationship to their political community' (Scharpf, 2009, p. 272).

As field of action and of policy, VET is of critical and central importance for European citizens, and even more so for VET research. However, it is unlikely that the tensions and problems of legitimacy will be resolved in coming years or that they will become obsolete. It seems all the more important that VET research adopts this topic as its own field of research. It would at the very least be meaningful, if the discipline would move to actively understand, study, and help shape a process and all it implies for the discipline's central research subject - and in this way perhaps rediscover a research subject that it can call its very own.

\section{NOTES}

Blaizot, Case 24/86, Decision by the ECJ 02.02.1988.

Gravier, Case 293/83, Decision by the ECJ 3.02.1983.

\section{REFERENCES}

Aleman, U.V. (1994). Grundlagen der Politikwissenschaft. Opladen: Budrich.

Barnier, M. (2003). The future of European regional policy. Intereconomics, 38(6), 292-310.

BMBF. (2012). Erläuterungen zum Anerkennungsgesetz des Bundes. Berlin: BMBF. 
Bohlinger, S. (2008). Kompetenzentwicklung für Europa. Opladen: Budrich.

Dye, T. R. (1978). Understanding public policy. Englewood Cliffs, NJ: Prentice Hall.

Council of the European Economic Community. (1963). Council Decision of 2 April 1963 laying down general principles for implementing a common vocational training policy. Brussels: 63/266/EEC.

European Commission. (2010). Communication from the Commission. Europe 2020. A strategy for smart, sustainable and inclusive growth. Brussels: COM (2010) 2020 final.

European Council. (2000). Presidency note on employment, economic reforms and social cohesion. Towards a Europe based on innovation and knowledge. Brussels: 5256/00 + ADD1 COR 1 (en).

European Council. (2009). Council conclusions of 12 May 2009 on a strategic framework for European cooperation in education and training ('ET 2020'). Official Journal of the European Union, Brussels: 2009/C 119/02-10.

European Council. (2012). Statement of the members of the European Council: Towards growthfriendly consolidation and job-friendly growth. Strasbourg: Motion for a Resolution. B[7-/2012].

European Council \& European Commission. (2002). Detailed work programme on the follow-up of the objectives of education and training systems in Europe. Official Journal of the European Union, Brussels: C 142/01.

European Council \& European Parliament. (2008). Recommendation of the European Parliament and the European Council of 23 April 2008 on the establishment of the European Qualifications Framework for lifelong learning. Brussels: COM (2008) 111/01.

European Parliament \& Council of the European Union. (2005). Directive 2005/36/EC on the recognition of professional qualifications. Brussels.

European Parliament \& Council of the European Union. (2013). Regulation (EU) No. 1304/2013 of 17 December 2013 on the European Social Fund and repealing Council Regulation. Brussels: (EC) No. $1081 / 2006$.

Hall, P. A. (1993). Policy paradigms, social learning, and the state. Comparative Politics, 25(3), 275296.

Howlett, M., \& Ramesh, M. (1993). Patterns of policy instrument choice: Policy styles, policy learning and the privatization experience. Policy Studies Review, 12(1/2), 3-24.

Jachtenfuchs, M., \& Kohler-Koch, B. (2004). Governance in der Europäischen Union. In A. Benz (Ed.), Governance - Regieren in komplexen Regelsystemen (pp.77-102). Wiesbaden: Budrich.

Kutscha, G. (1997). Berufsbildungssystem und Berufsbildungspolitik. In D. Kahsnitz, G. Ropohl, \& A. Schmid (Eds.), Handbuch zur Arbeitslehre (pp. 649-686). München, Wien: Oldenbourg.

Lauth, H.-J., \& Thiery, P. (2009). Politikfeldanalyse. In H.-J. Lauth, \& C. Wagner (Eds.), Politikwissenschaft (6. Auflage). München: UTB, 263-293.

Lowi, T.J. (1972). Four systems of policy, politics, and choice. Public Administration Review, 32(4), $298-310$.

Münk, D. (2006). Berufliche Aus- und Weiterbildung in Europa. In R. Arnold, \& A. Lipsmeier (Eds.), Handbuch der Berufsbildung (pp. 547-560). Wiesbaden: VS.

Peters, B. G. (2005). The problem of policy problems. Journal of Comparative Policy Analysis, 7(4), 349-370.

Rechnungshof. (2007). Bericht des Rechnungshofs. Reihe Bund, 14, Wien, 97-116.

Rodriguez-Pose, A., \& Fratesi, U. (2004). Between development and social policies: The impact of European structural funds in objective 1 regions. Regional Studies, 38(1), 97-113.

Sabatier, P. (1993). Advocacy-Koalitionen, Policy-Wandel und Policy-Lernen: Eine Alternative zur Phasenheuristik. In A. Héritier (Ed.), Policy-Analyse. Kritik und Neuorientierung. Politische Vierteljahresschrift, Sonderheft 24 (pp. 116-148). Opladen: Budrich.

Scharpf, F.W. (2000). Interaktionsformen. Akteurszentrierter Institutionalismus in der Politikforschung. Opladen: Budrich.

Scharpf, F. W. (2003). Politische Optionen im vollendeten Binnenmarkt. In M. Jachtenfuchs \& B. Kohler-Koch (Eds.), Europäische Integration (pp. 219-253). Opladen: Budrich. 


\section{S. BOHLINGER}

Scharpf, F. W. (2009). Legitimität im europäischen Mehrebenensystem. Leviathan, 37, 244-280.

Szukala, A. (2012). Das Implementationssystem europäischer Politik. Wiesbaden: VS.

\section{Sandra Bohlinger}

Faculty of Education

Dresden University of Technology, Germany 


\title{
SANDRA BOHLINGER, ULRIKA HAAKE, CHRISTIAN HELMS JØRGENSEN, HANNA TOIVIAINEN AND ANDREAS WALLO
}

\section{CONCLUSION}

\author{
The Contested Field of Working and Learning
}

\begin{abstract}
Work in times of globalisation and uncertainty is undergoing considerable changes, which has strengthened the importance of work as a site of learning. New trends in production, such as digitalisation, challenge traditional modes of producing goods and services. Emerging forms of flexible production and knowledge-work offer growing learning opportunities to people throughout their active working life. In contrast to the stable and standardised modes of Fordist production, modern working life is characterised by rapid changes and employees interacting across globally distributed professional and spatial production networks. Based on continuous relationships of mutual exchange and knowledge building between customers, suppliers and producers, these kinds of learning environments are essentially different from those offered in a school setting. More research is needed to explore the opportunities and obstacles to enhance learning through negotiation and boundary-crossing between different areas of expertise and professionalism. We are far from seeing rich learning environments provided to large groups of lowskilled workers in poor working conditions at the bottom of the global supplier chains.
\end{abstract}

This book explores the challenges of working and learning on the boundaries between education and working life. Globalisation affects the transition patterns from vocational education to the labour market in many ways (Schoon \& Silbereisen, 2009), even though the specific challenges to national-level policies vary and need consideration. In Norway, for example, the presently high employment figures for graduates reflect the good economic situation, but they also suggest that vocational training in general provides skills and qualifications that are in demand in the Norwegian labour market. This is discussed in the research of Torgeir Nyen, Asgeir Skälholt and Anna Hagen Tønder. Closer examination of their register data reveals some complicated transition patterns, such as gender-related differences in employment and young graduates' tendency to escape vocational paths in order to keep their options open for higher education.

The chapters of this book refer widely to the learning challenges that individuals and teams face in their workplaces, and also to the adult educational themes that enter into the socio-political discussion in the European context. Work is changing in order to keep pace with the developments of societal production and technology, 


\section{S. BOHLINGER ET AL.}

to meet the needs of the customers and consumers, and to implement economically and, increasingly, also ethically and ecologically sound work practices in a global world (Garriga \& Melé, 2004).

The analysis of learning in and for work in this volume deals with paid work, but our concluding remarks should take a broader view, to encompass collective productive activities, including civic activity and voluntary work. The following thematic areas of interest cut across the micro, meso and macro levels discussed in the three parts of the book. In addition to summarising the findings of the chapters, the discussion aims to open up focal themes for future adult education research on working and learning.

\section{A TENACIOUS HISTORY OF SEPARATING WORKING AND LEARNING}

Historically, participation in work practices has been the most common way of becoming a recognised member of a community and of a larger society. The significance of learning by working for social integration, recognition and selfesteem have been emphasised in research (e.g. Billett, 2011; Lave \& Wenger, 1991). Learning also includes acquiring the social and cultural codes of the local communities of work and learning within the established hierarchical division of work. The Taylorist scientific management and rationalisation of industrial production replaced craft work as the dominant form of production and aggravated the degradation of work as a site of learning (Sennett, 1998). Particularly in industrialised countries, where Taylorism prevailed, learning was separated from work sites and work was reduced to the acquisition of company-specific skills in order to perform simple job tasks (Sawchuck, 2010). Apprenticeship, which is the archetypal form of learning a craft, was replaced in most countries by school-based forms of learning (Solga, 2008). This historical shift is associated with a shift in the hierarchical structuring of modern societies, where formal education and credentials have become more decisive for the attainment of social positions (Bourdieu, 1996).

The substitution of work-based learning by school-based learning has not only affected the context and organisation of learning, but also the content of learning and epistemology of knowledge. Learning of standardised, codified and abstract knowledge for work in educational institutions has displaced the learning of situated, specific and embodied knowledge in work (Lave \& Wenger, 1991; Tynjälä, 2008). The practice-based and experiential forms of knowledge, which are embedded in the norms and values of local occupational communities, have been degraded and eroded (Lejeune, 2011). In sum, knowledge drawn from recognised academic and professional theories has come to dominate over knowledge that is useful and applicable based on personal and practical experience ("practical sense") and over knowledge that is right and meaningful according to the cultural worlds of occupational communities ("common sense") (Jørgensen, 2009).

Globalisation directly affects educational systems through the frequent comparisons and regulations promoted by international agencies like the EU and the OECD. We refer to Sandra Bohlinger's analysis that recognises a steady 
expansion of the European Union's governance principles critically affecting VET in member states. International rankings focus on the measurable and easily comparable formal levels of education, and accelerate the devaluing of knowledge and skills developed though work. The increasing dominance of formalised, school-based and academic education has been driven by self-sustaining dynamics as a consequence of the marketisation of education. As higher education is assigned an ever higher value in society, the consumerised choices of young people tend to be marked by an "academic drift" promoted by the growing positional value of education (Smeby, 2015).

The continuing expansion of formal education has raised concern over the "academisation" of professional and vocational education, as described in the chapter by Thomas Bäck on the competing forms of knowledge in police education. He demonstrates that specific knowledge, practical skills and reflexive knowledge are all valued by police-students as important competencies for their future careers. However, towards the end of their training programme, the practical skills dimension in particular, is valued lower than at the beginning. The process of academisation is not just a result of the competition for higher credentials or professional organisations' interests in the struggle for higher status. It is also a result of demands from below, from individuals searching for higher levels of general knowledge in order to manage their lives and pursue their work-life careers. The resulting academic drift of young people and the academisation of educational programmes have increasingly raised concern over the weaknesses and limitations of school-based studies and of propositional knowledge.

\section{RETURN TO WORKING AND LEARNING IN EDUCATION}

As structural transformation is moulding the societal practices of production, work activities typically consist of novel, unique and unpredictable problems and situations that are only captured to a limited extent through school-based education. The practice of experienced professionals constitutes a valuable base of interdisciplinary and problem-oriented knowledge that has been tested and refined through practice. This knowledge is situated and embodied and cannot easily be coded, transferred and deposited in databases and textbooks or transmitted in classrooms. It has to be learned through experience and mimetic learning at work (Billett, 2014). To master complexity, we may add, the development of theoretical knowledge is also essential and requires collaboration between professional practices, research and education.

Against the historical background outlined in the previous section, we see how the quality and effectiveness of learning at work has been questioned, and how the advantages of school-based learning have been emphasised. This has supported the academisation of professional and vocational education. However, academisation has come under increasing critique. One of the critical voices comes from the professional practitioners, who strive to develop a professionalism that combines a scientific body of knowledge with a strong base of experiential and practice-based knowledge. This voice is critical of the increasingly one-dimensional valuing of 
propositional and codified knowledge and, in opposition to this, it struggles to regain recognition for tacit, processual, bodily and practical forms of knowledge (Eraut, 2011).

The turn towards workplace learning is not only of academic interest and not only concerns specialised professions. It also reflects an interest among unskilled and semiskilled workers and non-academic youths, who may have low expectations regarding the benefits of formalised adult education. Even if they are interested in further education and training, the barriers in terms of time, distance, finance and access are bigger than for the actively participating population. From this point of view, the workplace can offer many employees a more relevant and meaningful learning environment than the classroom does - if they perceive real opportunities and support for learning at work. Sissel Kondrup analyses the concept of learner identity for low skilled workers. While the combination of a low level of skills and a specific work-life history plays a role in assuming a reluctant learner identity, new experiences in the workplace can transform an employee into an engaged learner.

While some employees gain access to a richer learning environment with more opportunities for learning, others seem to be stuck in low skills jobs with few opportunities for change. This may be the case, for example, in female-dominated lines of work, such as care work. Dan Rönnqvist, Andreas Wallo, Peter Nilsson and Bo Davidson analyse care work for elderly people, which increasingly encounters problems retaining and recruiting employees. To increase the attractiveness of the work, access to a rich learning environment in the workplace would be a crucial factor. People have struggled for decades to achieve equal access to formal education, but what happens when learning at work becomes more decisive for people's life chances and for stable employment? Are we moving towards a new polarisation between, on the one hand, higher-ranking professionals with autonomy, challenging jobs and learning opportunities and, on the other hand, lower ranking workers with routine jobs with little autonomy?

Vocational and professional education research and policy pay growing attention to the large cohorts of graduates from higher education that encounter regular problems gaining access to stable employment on an adequate level of qualification (Green \& Zhu, 2010). These problems have given rise to a questioning of the value of academic education and have sparked heated debates about credentials inflation, over-qualification, under-employment and the precarious employment situation for graduates (Scurry \& Blenkinsopp, 2011). In the European VET systems, we have also witnessed a growing interest in workbased learning, often in an attempt to introduce modernised forms of apprenticeship e.g. in the "European Alliance for Apprenticeships" (European Commission, 2013). As a result of this shift towards work and learning in education policies, we have seen a multitude of political measures over the last decade to introduce internships and work-integrated learning in all types of education (Livingstone, 2013).

Learning in the context of work depends not only on the structures and on opportunities in the individual workplace, but also on the larger institutional 
environment that regulates learning in the context of work. Comparative research has identified significant differences in the institutional architectures that regulate workplace learning in the training regimes of different states and industries (Svensson \& Evetts, 2003). David Ashton (2004) uses the concept "the political economy of workplace learning" to analyse different national regimes for learning at work. These differences are particularly conspicuous between different national systems of vocational education and training, for example between the UK and Germany. In the market-led UK regime, the individual training company (the organisation) is the primary context for learning, while in Germany the primary context is the profession/vocation (Beruf), with its broad and standardised curricula and corporatist governance (Deissinger, 1998; Thelen, 2004). Consequently, the quality and standards for work-based training is generally higher in Germany than in the UK.

\section{PARTICIPATION AND CO-CONFIGURATION WORK}

As discussed above, a vital area for the working and learning research stems from the recognition of multi-professional collaboration in solving complex global problems. This involves work across boundaries of different domains of knowledge and expertise (Akkerman \& Bakker, 2011; Edwards \& Daniels, 2012; Guile, 2011). The mastery of complexity and cross-border activity is strongly represented in the current discourse of organisational leadership. This can be read from Gun Sparrhoff's analysis of contemporary leadership research. The image of charismatic leaders has been replaced by the request for a strategic leadership involving organisational self-awareness, self-reflection and a will to change, she states.

To realise organisational volition for change, participants have to envision and model the direction of future development. The notion of "co-configuration work" (Engeström, 2004; Victor \& Boynton, 1998) represents a historically emerging model for work that combines knowledge and interests from multiple sources and agencies spanning over the lifecycle of products, innovations etc. Co-configuration is a global concept to be translated and contextualised in local activity, which represents a real learning challenge for the learners and the adult educators. Interpreted in this theoretical-historical framework, Kirsi Kallio's analysis reveals a structural contradiction between the traditional product-based value creation of mass production, and the new offering-based business of co-configuration, which allows researchers to specify the learning challenges in the front-line automation service work and to propose concrete steps for competence development.

By means of sophisticated learning intervention methods, the researchers of work and learning can involve the participants in the analysis of the changes that are occurring at workplaces and in an operational environment. Development of work and learning practices go hand in hand (e.g. Virkkunen \& Schaupp, 2011). In a similar vein, Hanna Toiviainen argues that learning has become an integral part of working and even more so in the co-configuration work. It is therefore not irrelevant how and on which theory-historical basis the participants in change 
processes conceptualise learning, as their conceptions significantly mould the visions of developmental directions and possibilities. The participation approach that has largely dominated the work-related adult education research (Fuller \& Unwin, 2005) is deeply rooted in local, face-to-face practices, which is one reason to search for new concepts of global work and learning. In sum, the recognition of co-configuration work across organisational and professional boundaries, combined with participative learning interventions analysing and modelling the transformation, could have a potential for expanding leadership and participation in global work.

\section{UNDERSTANDING KNOWLEDGE}

Enhancement of professional knowledge and learning in and for work should not confine itself to cognitively oriented contents that are measurable and possible to grade according to corporate competence descriptions or educational standards. We have already discussed in the preceding sections the need to extend the meaning of knowledge and to overcome the dichotomy between the school and work-based or academic and practical knowledge. Our goal is supported by the increased focus on practice in the research of work, which has actually expanded the ways we presently understand knowledge and learning in work activities (Miettinen et al., 2009; Schatzki et al., 2001). Several chapters in this book (see Kondrup, Dau, Sparrhoff, Kallio, Fejes \& Andersson, and Quesada-Pallarès et al.) approach knowledge by opening up new connections, rather than categorising or isolating differing types of knowledge.

In the analytical framework developed by Sissel Kondrup, the formulation of learning identity embraces knowledge that emerges from people's historical life experiences and their bodily and practical engagement in work. These elements give rise to concerns and emotions about feeling competent, being in charge of the quality of work etc. Learning identities direct people's perception of their needs and opportunities to participate in job-related adult education and training.

Susanne Dau's analysis of learners at workplaces shows that access to tacit knowledge and cooperative relationships (or lack of these) are crucial for knowledge development during an internship period. Online technology has a potential to connect the students with national and international professional networks, enhancing mutual learning, knowledge exchange and broader perspectives into practical problems of local work. The knowledge practices to support the use of advanced technology and networking (Hakkarainen, 2009), however, were underdeveloped and the connections geographically bounded.

Learner identity and access to professional networks, and the knowledge creation involved, are outlined above by taking a practical and situational perspective on a learner's position in work activities. The chapters of this volume also present some more formalised approaches to experiment with and support learning and knowledge-building in and for work. Based on a survey of the link between training and innovation, Carla Quesada-Pallarès, Anna Ciraso-Cali, Pilar Pineda-Herrero, and Angela Janer-Hidalgo explore the role of human resource 
development practices in organisations. In the light of their findings, training that aims to generate innovation has a higher degree of deferred transfer than training not related to innovation. A training programme's focus on innovation and change may encourage participants to apply at work what they have learned. Knowledge creation, learning transfer and the transformation of work are intertwined. Analysing learning transfer in continuing vocational training, Michael Gessler and Anja-Christina Hinrichs argue for an integrative model that approaches transfer through both process and outcome data and that links transfer and transformation. They highlight that learning transfer in continuing vocational training should be considered as a context-related transformation of knowledge, where both the training and the work environment constitute learning resources for each other. In sum, connecting learning and transformation is a challenge, both for work-related training practices and educational research and it requires a re-conceptualisation of the notion of transfer (Tuomi-Gröhn \& Engeström, 2003; Tynjälä, 2009).

Recognition of prior learning also represents a formal approach for identifying, assessing, and documenting knowledge that people have gained through experience and personal learning history. By employing a constructivist perspective to the inservice training cases analysed, Andreas Fejes and Per Andersson demonstrate how a prior learning assessment process simultaneously produces new knowledge and initiates new learning processes, particularly when facilitated by discussion as the training method. Experience, assessment, collective reflection and the creation of new knowledge are inseparable. However, the research methods have to be refined enough to identify these different aspects of recognising prior learning, eventually contributing to the renewal of the adult education practices.

\section{POWER AND LEARNING PARTNERSHIP}

Power affects the conditions of work-related learning on many levels, but in multiple and mediated ways, which have to be opened up and unveiled through analysis. This is done in Sandra Bohlinger's macro-level analysis, revealing tensions in the member states' recognition of and adaptation to the EU's VET policy. On the organisational level, Roome and Wijen (2006) have pointed out that stakeholder power influencing corporate learning can come from many sources: personal skills, knowledge and networks, formal authority and operational capacity. The critical analysis by Rafael M. Hernández-Carrera and Emilio LucioVillegas in this volume reveals that the funding system for training programs can result in satisfying the powerful financial interests of large employer organisations, rather than supporting participative worker training.

Ola Lindberg, Oscar Rantatalo and Ulrika Haake discuss tensions of learning in a police organisation. The top management initiatives for change and innovation are received with suspicion and resistance by the leaders in lower management positions, who are primarily oriented towards the "grounded" leadership near daily practices. Moreover, the police leaders find themselves caught in a squeezed position between various expectations by societal, organisational and institutional 


\section{S. BOHLINGER ET AL.}

stakeholders, which cannot but have an effect on their readiness to involve themselves in change and innovation initiatives.

Power and the interests and influences involved are reported to problematise and hinder learning, as the research cases above confirm. However, there are also interesting efforts to deal with the tensions in the design of learning forums and environments (Toiviainen \& Kerosuo, 2013). The notions of the "third space" (Gutierrez, 2008) and the "third learning environment" (Goetze et al., 2002) represent such designs. Christian Helms Jørgensen gives timely examples of the third learning environments that can mediate between school and workplace to combine the best features of educational institutions and work sites. The Danish training centres, the Norwegian training agencies and the Swiss training associations (Lehrbetriebsverbund) are examples of new institutions for collaboration between the stakeholders responsible for work-based training of students.

To conclude, the organisation of learning in and for work takes place in the field of tensions between power relations, interests and influences, which are always present in work practices. Examples of the "third spaces" show that it is possible to create forums for learning that connect the interest groups on a common ground, but also allow them to deal with the tensions and express different views. Building such learning environments and learning partnerships, however, requires specific capabilities from all stakeholders and is thus a collective learning and training challenge in itself.

\section{REFERENCES}

Akkerman, S. F., \& Bakker, A. (2011). Learning at the boundary: An introduction. International Journal of Educational Research, 50(1), 1-5.

Ashton, D. N. (2004). The political economy of workplace learning. In H. Rainbird, A. Fuller, \& A. Munro (Eds.), Workplace learning in context (pp. 38-53). London: Routledge.

Billett, S. (2011). Vocational education: Purposes, traditions and prospects. Dordrecht: Springer Science \& Business Media.

Billett, S. (2014). Mimetic learning at work: learning in the circumstances of practice. Netherlands: Springer.

Bourdieu, P. (1996). The state nobility. Stanford: Stanford University Press.

Deissinger, T. (1998). Beruflichkeit als 'organisierendes Prinzip' der deutschen Berufsausbildung. Markt Schwaben: Eusl.

Edwards, A., \& Daniels, H. (2012). The knowledge that matters in professional practices. Journal of Education and Work, 25(1), 39-58.

Engeström, Y. (2004). New forms of learning in co-configuration work. Journal of Workplace Learning, 16(1/2), 11-21.

Eraut, M. (2011). Developing a broader approach to professional learning. In A. Mc Kee \& M. Eraut (Eds.), Learning trajectories, innovation and identity for professional development (pp. 21-45). Dordrecht: Springer Netherlands.

Fuller, A., \& Unwin, L. (2005). Older and wiser? Workplace learning from the perspective of experienced employees. International Journal of Lifelong Education, 24(1), 21-39.

Garriga, E., \& Melé, D. (2004). Corporate social responsibility theories: Mapping the territory. Journal of Business Ethics 53(1-2), 51-71. 
Goetze, W., Gonon, P., Gresele, A., Kübler, S., Landolt, H., Landwehr, N., \& Egger, P. (2002). Der dritte Lernort. Bildung für die Praxis, Praxis für die Bildung. Bern: hep-Verlag.

Green, F., \& Zhu, Y. (2010). Overqualification, job dissatisfaction, and increasing dispersion in the returns to graduate education. Oxford Economic Papers - New Series, 62(4), 740-763.

Guile, D. (2011). Interprofessional learning: Reasons, judgement, and action. Mind, Culture, and Activity, 18(4), 342-364.

Gutiérrez, K. D. (2008). Developing a sociocritical literacy in the third space. Reading Research Quarterly, 43(2), 148-164.

Hakkarainen, K. (2009). A knowledge-practice perspective on technology-mediated learning. International Journal of Computer-Supported Collaborative Learning, 4(2), 213-231.

Jørgensen, C.H. (2009). Three conceptions of the changing relations between education and work. In M. Weil, L. Koski, \& L. Mjelde (Eds.), Knowing work (pp. 187-208). Bern, Berlin, New York: Peter Lang.

Lave, J., \& Wenger, E. (1991). Situated learning: Legitimate peripheral participation. Cambridge: Cambridge University Press.

Lejeune, M. (2011). Tacit knowledge: Revisiting the epistemology of knowledge. McGill Journal of Education/Revue des sciences de l'éducation de McGill, 46(1), 91-105.

Livingstone, D.W. (2013). The learning society. In M. Mayo (Ed.), Learning with adults (pp. 33-53). Dordrecht: Springer.

Miettinen, R., Samra-Fredericks, D., \& Yanow, D. (2009). ReTurn to practice: An introductory essay. Organization Studies, 30(12), 1309-1327.

Roome, N., \& Wijen, F. (2006). Stakeholder power and organizational learning in corporate environmental management. Organization Studies 27(2), 235-263.

Sawchuk, P.H. (2010). Revisiting Taylorism. In D. W. Livingstone (Ed.), Lifelong learning in paid and unpaid work (pp. 101-119). Abingdon: Routledge.

Schatzki, T. R., Knorr-Cetina, K., \& Savigny, E. V. (2001). The practice turn in contemporary theory. London: Taylor and Francis Ltd.

Schoon, I., \& Silbereisen, R. K. (Eds.). (2009). Transitions from school to work: Globalization, individualization, and patterns of diversity. Cambridge: Cambridge University Press.

Scurry, T., \& Blenkinsopp, J. (2011). Under-employment among recent graduates: A review of the literature. Personnel Review, 40(5), 643-659.

Sennett, R. (1998). The corrosion of character: The transformation of work in modern capitalism. New York and London: Norton Company.

Smeby, J. C. (2015). Academic drift in vocational education? In J.-C. Smeby \& M. Sutphen (Eds.), From vocational to professional education: Educating for social welfare (pp. 7-25). Oxford: Routledge.

Solga, H. (2008). Skill formation: Interdisciplinary and cross-national perspectives. Cambridge University Press.

Svensson, L., \& Evetts, J. (Eds.). (2003). Conceptual and comparative studies of continental and AngloAmerican professions. Goteborg Studies in Sociology No. 129. Goteborg University.

Thelen, K. (2004). How institutions evolve: The political economy of skills in Germany, Britain, the United States, and Japan. Cambridge: Cambridge University Press.

Toiviainen, H., \& Kerosuo, H. (2013). Development curriculum for knowledge-based organizations: Lessons from a learning network. International Journal of Knowledge-Based Organizations (IJKBO), 3(3), 1-18.

Tuomi-Gröhn, T., \& Engeström, Y. (2003). Conceptualizing transfer: From standard notions to developmental perspectives. In T. Tuomi-Gröhn \& Y. Engeström (Eds.), Between school and work: New perspectives on transfer and boundary-crossing (pp. 19-38). New York: Pergamon.

Tynjälä, P. (2008). Perspectives into learning at the workplace. Educational Research Review, 3(2), $130-154$. 


\section{S. BOHLINGER ET AL.}

Tynjälä, P. (2009). Connectivity and transformation in work-related learning - Theoretical foundations. In M. L. Stenström \& P. Tynjälä (Eds.), Towards integration of work and learning: Strategies for connectivity and transformation (pp. 11-37). Dordrecht: Springer Science \& Business Media.

Victor, B., \& Boynton, A. C. (1998). Invented here. Maximizing your organization's internal growth and profitability. Boston: Harvard Business School Press.

Virkkunen, J., \& Schaupp, M. (2011). From change to development: Expanding the concept of intervention. Theory \& Psychology, 21(5), 629-655.

\section{Sandra Bohlinger}

Faculty of Education

Dresden University of Technology, Germany

\section{Ulrika Haake}

Department of Education

Umeå University, Sweden

Christian Helms Jørgensen

Department of Psychology and Educational Studies

Roskilde University, Denmark

\section{Hanna Toiviainen}

Center for Research on Activity, Development and Learning (CRADLE)

Institute of Behavioural Sciences, University of Helsinki, Finland

Andreas Wallo

Department of Behavioural Sciences and Learning

Linköping University, Sweden 


\section{LIST OF CONTRIBUTORS}

Per Andersson is Professor of Education at Linköping University in Sweden. His research interests include the recognition of prior learning, and conditions for work in the teacher profession. Lately he has taken a special interest in the continuing professional development of vocational teachers.

Thomas Bäck is a PhD Student in Education, at Umeå University, Sweden. His research interests include learning and leadership in working life and organisation. In the last years he has been interested in the Police Training Program, which is also the subject for his dissertation. His special interest is the transition from education to work and comparative studies within the RECPOL project (Recruitment, Education and Career in the Police).

Sandra Bohlinger is Professor of Adult Education at Dresden University of Technology, Germany. Her research interests are in adult and vocational education and training, international and comparative education, skills development and education policy.

Anna Ciraso-Calí is a Pedagogue and Researcher at the Universitat Autònoma de Barcelona, Spain. Her main research fields are transfer of learning, VET, teacher training and participatory evaluation. In the professional area, she has experience as a professional educator in non-formal education.

Susanne Dau is a Lecturer at University College North (UCN), Denmark and a Ph.D. Student in the Department of Communication and Psychology at Aalborg University (AAU), Denmark. She is part of the research E-learning Lab Centre and the research network 'On the Definition of Learning'. Her primary research interests are within qualitative and narrative research, within the fields of learning, knowledge development and way-finding in blended learning environments.

Bo Davidson is a Senior Lecturer in Education at Linköping University, Sweden. His research interests include learning and development processes in organisations, competence development, and interactive research.

Andreas Fejes is Professor of Adult Education research at Linköping University in Sweden. His research interests include the marketisation of adult education, citizenship education, recognition of prior learning, and the bibliometrics of adult education research. 
Michael Gessler is a Professor at the Institute for Technology and Education at the University of Bremen, Germany. His research covers Initial Vocational Education and Training (IVET) and Continuous Vocational Education and Training (CVET) with a special emphasis on Workforce Education and Development, Education Management, and Innovation in IVET/CVET.

Ulrika Haake is an Associate Professor in Education and Pro Dean at the Faculty of Social Sciences at Umeå University, Sweden. Her research interests include leadership and gender in a culture of change. In recent years she has taken a special interest in research on leadership within the police organisation but she also does research in the area of Higher Education.

Rafael M. Hernández Carrera is Doctor in Education and holds the position of Assistant Professor at the Faculty of Education at the International University of La Rioja, Spain. His research is focused on lifelong learning, workplace learning and worker education. During the last 16 years he has been holding the position of Chief Learning Officer in several transnational consultancy firms.

Anja-Christina Hinrichs, $\mathrm{PhD}$, is a Personnel Officer for International Human Resource Development at Mubea Muhr and Bender KG in Attendorn, Germany. Mubea creates innovative solutions for future vehicle generations.

Àngela Janer-Hidalgo is a Pedagogue and a $\mathrm{PhD}$ student at the Universitat Autònoma de Barcelona, Spain. She collaborated in researches on evaluation of success features in disadvantaged schools, evaluation of tutoring processes at university and workplace learning and transfer. Her research is focused on Social Pedagogy from an international and comparative perspective.

Christian Helms Jørgensen is a Professor at Department of Psychology and Educational Studies, Roskilde University in Denmark. His main research field is adult and vocational education, school-to-work transitions of young people and comparative studies of vocational education, currently as leader of a major comparative research project in the Nordic countries, www.Nord-VET.dk.

Kirsi Kallio (Phil. Lic.) is a Doctoral Student in the Centre for Research on Activity, Development and Learning (CRADLE), at the University of Helsinki. She works as a part-time university lecturer and teaches courses on adult education, work-related learning, and developmental work research. Her research interests have addressed new forms of production and learning, especially the collaboration needed in co-configuration work.

Sissel Kondrup is former Postdoc at Department of Psychology and Educational Studies, Roskilde University, Denmark. Her research focus primarily on adult and vocational education and training, work and learning, learning in unskilled and low 
skilled work, educational policy and educational institutions as learning organisations.

Ola Lindberg is a Senior Lecturer at the Department of Education, Umeå University, Sweden. His research interests concern education-work transition and professional socialisation.

Emilio Lucio-Villegas holds a $\mathrm{PhD}$ in Education. His research is focused on Adult Education, Citizenship and Participatory Research. From 2008 to 2013 he was Head of The Paulo Freire Chair at the University of Seville. He holds the Phyllis M. Cunningham Award for Social Justice presented in 2010.

Peter Nilsson is a Senior Lecturer in Education at Linköping University, Sweden. His research interests include leadership, leadership development, HRD, and learning in organisations.

Torgeir Nyen is a Senior Researcher at Fafo, which is a social science research institute in Oslo, Norway. His research fields include vocational education and training, in particular the transition from education to work, lifelong learning and education policy.

Pilar Pineda-Herrero holds tenure as Associated Professor of Economics of Education and Training in Organisations at the Universitat Autònoma de Barcelona, Spain. Her research is focused on life-long learning, workplace learning and transfer, VET, especially the evaluation of learning transfer and the efficacy of VET. She is the director of the Research Group on Training Efficacy (Grup EFI).

Carla Quesada-Pallarès is a Post-Doctoral Researcher at the Leeds Enterprise Centre of the University of Leeds, United Kingdom. Her researches are focused on workplace learning and transfer of learning, Vocational Education and Training (VET), gender participation in adult learning, and e-learning. Specially, her researches are based on a strong evaluation perspective through a quantitative methodology.

Oscar Rantatalo is a Senior Lecturer at the Centre for Police Education at Umeå University, Sweden. His research interests include areas such as competence, organisational sense-making, reflexive practice and police leadership.

Dan Rönnqvist is a Senior Lecturer in Education at Linköping University Sweden. His research interests include organisational change, HRM, HRD, competence development, and learning in organisations. Dan is especially interested in public sector organisations.

Asgeir Skålholt is a Researcher the Nordic Institute for Studies in Innovation, Research and Education in Oslo, Norway. His research interests are Vocational 


\section{LIST OF CONTRIBUTORS}

Education and Training and Continuous Vocational Education and Training with special emphasis on workplace learning and innovation.

Gun Sparrhoff is a Senior Lecturer at Linköping University in Sweden. Her research interests target learning and development in working life. She takes a special interest in the discursive production of trendy concepts, and how this affects organisational management and development. Her studies have addressed concepts such as lifelong learning, employability and globalisation. In the last years her studies have focused on the discursive production of organisational leadership.

Hanna Toiviainen, Docent, Senior Researcher, works at the Centre for Research on Activity, Development and Learning (CRADLE), University of Helsinki, Finland. Based on the concepts of Cultural-Historical Activity theory (CHAT) her research covers Adult Education in the area of workplace learning with the special emphasis on inter-organisational and network learning.

Anna Hagen Tønder is a Researcher and Research Coordinator at Fafo Institute for Labour and Social Research, Oslo, Norway. Her research interests include vocational education and training, school to work transitions and the development of skill formation systems.

Andreas Wallo is an Associate Professor in Education at Linköping University, Sweden. He is also affiliated to HELIX VINN Excellence Centre. Andreas' research interests include leadership and managerial work, HRM, HRD, organisational learning, and labour market intermediaries. 